\title{
RESPONSE OF MEDITERRANEAN-TYPE ECOSYSTEMS TO ELEVATED ATMOSPHERIC CO2 AND ASSOCIATED CLIMATE CHANGE
}

\author{
Final Report to the \\ Department of Energy \\ Program for Ecosystem Research \\ For the period \\ September 1, 1993 to December 31, 1999 \\ Principal Investigator: \\ Walter C. Oechel \\ Biology Department \\ San Diego State University \\ San Diego, California 92182 \\ Telephone: (619) 594-4818 \\ FAX: (619) 594-7831 \\ e-mail: oechel@sunstroke.sdsu.edu
}


Table of Contents

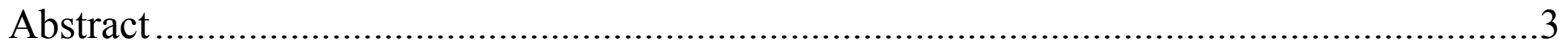

Brief Summary and list of publications, highlights and presentations resulting from this

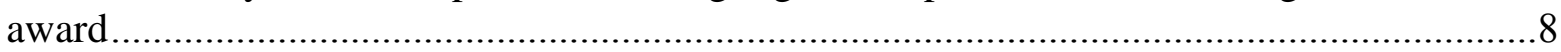

Initial progress for the period September 1, 1993 to August 31, 1996 ................................16

Ecosystem carbon flux under elevated $\mathrm{CO}_{2}$ by $\mathrm{CO}_{2}$ LT Chambers in southern California

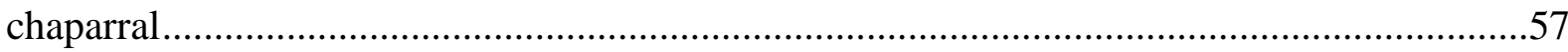

Negative feedbacks on global change already exist from a Mediterranean-type ecosystem....85

${ }^{13} \mathrm{C}$ tracers of carbon allocation to roots under a $\mathrm{CO}_{2}$ gradient in intact southern Californian chaparral

Alteration of soil carbon by communities of mycorrhizal fungi in a chaparral ecosystem exposed to elevated $\mathrm{CO}_{2}$

Effects of whole-ecosystem atmospheric carbon dioxide concentration manipulation on arthropod population dynamics in southern California chaparral

The relationship between atmospheric $\mathrm{CO}_{2}$ concentration and arthropod diversity in chaparral, and a model of the relationship between $\mathrm{CO}_{2}$ and succession

Effects of elevated atmospheric $\mathrm{CO}_{2}$ and hostplant density on psyllid abundance

Effects of lifelong $\left[\mathrm{CO}_{2}\right]$ enrichment on carboxylation and light utilization of Quercus pubescens Willd. examined with gas exchange, biochemistry and optical techniques 


\begin{abstract}
This research incorporated an integrated hierarchical approach in space, time, and levels of biological/ecological organization to help understand and predict ecosystem response to elevated $\mathrm{CO}_{2}$ and concomitant environmental change. The research utilized a number of different approaches, and collaboration of both PER and non-PER investigators to arrive at a comprehensive, integrative understanding.

Central to the work were the $\underline{\mathrm{CO}}_{2}$-controlled, ambient Lit, $\underline{\text { Temperature }}$ controlled $\left(\mathrm{CO}_{2} \mathrm{LT}\right)$ null-balance chambers originally developed in the arctic tundra, which were re-engineered for the chaparral with treatment $\mathrm{CO}_{2}$ concentrations of from 250 to $750 \mathrm{ppm} \mathrm{CO}_{2}$ in $100 \mathrm{ppm}$ increments, replicated twice to allow for a regression analysis. Each chamber was 2 meters on a side and 2 meters tall, which were installed over an individual shrub reprouting after a fire. This manipulation allowed study of the response of native chaparral to varying levels of $\mathrm{CO}_{2}$, while regenerating from an experimental burn. Results from these highly-controlled manipulations were compared against Free Air $\mathrm{CO}_{2}$ Enrichment (FACE) manipulations, in an area adjacent to the $\mathrm{CO}_{2} \mathrm{LT}$ null balance greenhouses. These relatively short-term results (5-7 years) were compared to long-term results from Mediterranean-type ecosystems (MTEs) surrounding natural $\mathrm{CO}_{2}$ springs in northern Italy, near Laiatico, Italy. The springs lack the controlled experimental
\end{abstract}


rigor of our $\mathrm{CO}_{2} \mathrm{LT}$ and FACE manipulation, but provide invaluable validation of our long-term predictions.

Arid and semi-arid ecosystems, worldwide cover about $50 \%$ of the terrestrial surface, about $25 \%$ of the carbon in biomass and soil carbon, and $16 \%$ of the NPP. The chaparral is felt to be a good model ecosystem for understanding and predicting the response of arid/semi-arid perennial, woody ecosystems to variations in $\mathrm{CO}_{2}$ and moisture availability. Because of the interest in the range of interactions and feedbacks likely to act in nature, a field approach was felt to be critical. The California chaparral, a Mediterranean-type ecosystem, is a warm, semi-arid, nutrient-adequate ecosystem which we predicted to be particularly responsive to changes in $\mathrm{CO}_{2}$ and moisture availability. The presence of lignotubers was hypothesized to provide a strong sink for photosynthate. A range of responses and interactions to elevated $\mathrm{CO}_{2}$ are possible including those which would limit nutrient availability, as well as those which would increase it. While water use efficiency was predicted to increase under elevated $\mathrm{CO}_{2}$, compensatory responses via nutrient limitation, or an increase in leaf area per unit ground area, could potentially constrain and or prevent any ecosystem level increases in water yield. While not specifically addressed, the integrated responses studied will help in predicting potential responses of chaparral under a warmer, $\mathrm{CO}_{2}$ enriched environment and any feedbacks on changes in the fire frequency. A change in the fire frequency, due to 
an increase in biomass, could in and of itself, dramatically alter the water yield of the system, as could any large scale change in the community structure.

In the $\mathrm{CO}_{2} \mathrm{LT}$ chambers the dominant plant species, Adenostoma fasciculatum, in the $750 \mathrm{ppm} \mathrm{CO}_{2}$ chamber showed increased leaf-level photosynthesis, and decreased transpiration and stomatal conductance relative to controls at ambient $\mathrm{CO}_{2}$.

Measurements of above ground growth and leaf area index (LAI) showed no increase over the first three years of the study, though GPP increased 56\% over this time, suggesting most of the response was below ground. Net ecosystem exchange (smaller source or larger sink) increased under increasing $\mathrm{CO}_{2}$ treatment through time with effects being less during wet years. In the last 2 years of treatment, a $200 \%$ increase in sink strength was observed in the plants treated with $750 \mathrm{ppm} \mathrm{CO}_{2}$ compared to those at ambient. The plants grown at this high, $\mathrm{CO}_{2}$ concentration showed a $150 \%$ increase in aboveground biomass.

A. fasciculatum in the FACE ring (550 ppm), exhibited typical long-term acclimation responses to increased $\mathrm{CO}_{2}$ during the spring relative to plants growing in the control ring (ambient). Photosynthetic capacity and Rubisco activity were reduced on a leaf area basis, but leaf area increased. In the summer, plants showed a response more typical of short-term exposure to increased $\mathrm{CO}_{2}$, with $97 \%$ higher photosynthesis rates than controls. There were no differences in photosynthesis between treatments during the winter. These leaf level measurements were similar to those made on the plants in the null balance treatment. 
There is evidence that both litter quality and quantity has changed in the FACE treatment. In the spring, total non-structural carbohydrates (TNC) were $32 \%$ higher in leaves of FACE plants. Biogenic hydrocarbon emission, measured in the null balance chambers has also increased, suggesting increased $\mathrm{C}$ allocation to plant secondary compounds. Root production and rhizodeposition of $\mathrm{C}$ has increased substantially, based on ${ }^{13} \mathrm{C}$ isotope data from the chamber experiment.

In the null balance chambers, soil respiration rates measured in situ with a Li-Cor 6200 soil chamber were significantly lower in the $750 \mathrm{ppm} \mathrm{CO}_{2}$ treatments. This contrasts with the increased soil respiration measured in the FACE treatment using a Clapp cuvette $(122.5 \mathrm{~cm} \times 122.5 \mathrm{~cm} \times 82.0 \mathrm{~cm})$. While this discrepancy could reflect many differences in methodology and experimental conditions between the FACE site and the null balance chambers, the negative effect of $\mathrm{CO}_{2}$ on respiration found in the chambers could be related to the smaller spatial scale of the respiration measurements, indicating that when root respiration is excluded, microbial respiration is actually lower in the high $\mathrm{CO}_{2}$ treatments.

Two oaks (Quercus ilex and Q. pubescens) growing under elevated $\mathrm{CO}_{2}$ from natural springs in Italy were investigated for evidence of any down regulation of photosynthesis. Current year leaves showed no evidence of photosynthetic downregulation early in the growing season. In the case of $Q$. ilex, where older leaves were measured, down regulation was observed. The long term effect of elevated $\mathrm{CO}_{2}$ on 
both plants was an increase in LAI and while WUE was higher in the control areas, improved water relations of the elevated $\mathrm{CO}_{2}$ growing trees was not observed. 
Brief Summary and list of publications, highlights and presentations resulting from this award

In a Mediterranean system exposed to natural sources of $\mathrm{CO}_{2}$, Quercus pubescens response to elevated $\mathrm{CO}_{2}$ was that of increased photosynthesis based on measurements made in the spring when sink strength was the greatest (Stylinski et al., 2000). While this may result in increased biomass, other studies do not conclusively show that these higher photosynthetic rates in the spring will result in larger steady-state carbon pools. The possibility of down regulation during other times of the years, differential response of older leaves, and the response of belowground processes preclude a definitive statement on the response of the ecosystem to elevated $\mathrm{CO}_{2}$.

Growth chamber data from chaparral species did not show marked increases in carbon uptake under elevated $\mathrm{CO}_{2}$, in part due to down regulation (Oechel et al., 1995).

Elevated $\mathrm{CO}_{2}$ experiments in the field on chaparral plants suggest greater carbon sequestration, in part due to changes in soil structure. The greater carbon sequestration increased with years of treatment. Possibly of greater importance is that the change in soil structure may result in the stabilization of soil and help to mitigate soil degradation and erosion that might be accelerated by change in climate and land use and result in loss of carbon from the system (Rillig et al., 1999). 
Baldocchi D., Valentini R., Running S., Oechel W., and Dahlman R. 1996. Strategies for measuring and modeling carbon dioxide and water vapor fluxes over terrestrial ecosystems. Global Change Biology 2: 101-110.

This paper highlights the need, and a plan for measuring and modeling carbon and water flux of terrestrial ecosystems. While the effects of elevated $\mathrm{CO}_{2}$ on carbon flux are not specifically addressed, under a changing climate scenario, a change in the photosynthesis of plant under elevated $\mathrm{CO}_{2}$ could potentially change any conclusions drawn from "present day estimates" of flux.

Harney, S.L., Edwards F., and Allen M.F. 1997. Identification of arbuscular mycorrhizal fungi from Artemisia californica using the polymerase chain reaction. Mycologia 89: 547-550.

Ecological field studies focusing on arbuscular mycorrhizal fungi are hampered by the in ability to make accurate identification of species and hence changes in community composition. A method was developed using polymerase chain reaction to identify AM fungi.

Klironomos J.N., Rillig M.C., and Allen M.F. 1996. Below-ground microbial and microfaunal responses to Artemisia tridentate grown under elevated atmospheric $\mathrm{CO}_{2}$. Functional Ecology 10: 527-534.

Elevated $\mathrm{CO}_{2}$ has a qualitatively different effect on below-ground microbial and microfaunal communities depending upon whether or not additional nutrients were added. When nutrients were not added, carbon flow was shifted to a more mutualistic-closed mycorrhizal-dominated system while $\mathrm{CO}_{2}$ and nutrients resulted in a more opportunistic-open, saprobe/pathogen dominated one.

Klironomos J.N., Rillig M.C., and Allen M.F. 1999. Designing belowground field experiments with the help of semi-variance and power analyses. Applied Soil Ecology 12: 227-238.

Low sample size and the cryptic nature of the soil often results in low statistical power and high type II error rates. Using an elevated $\mathrm{CO}_{2}$ treatment, a geostatistical analyses was used to describe the spatial distribution of organisms and processes coupled with a power analysis to determine the required sample size. These a priori efforts helped determine which organisms are suitable for student under the scales of interest.

Moreno JM, and Oechel WC (eds.). 1995. Global Change and Mediterranean-Type Ecosystems. 117. Springer Verlag, New York, 527 pp. 
Regions with Mediterranean-type climates include parts of California, South America, Australia, and of course, Europe. The effect of global climate change on these heavily populated areas will have major social and political ramifications. This volume addresses issues in these areas, from processes at the leaf level to the individual, ecosystem, and landscape levels.

Moreno J.M., Cruz A., and Oechel W.C. 1999. Allometric relationships in two lignotuberous species from Mediterranean-type climate areas of Spain and California. Journal of Mediterranean Ecology 1: 49-60.

This study contrasts the dominant lignotuber producing plants in the Mediterranean regions of central Spain and southern California. Plants originating from southern California developed greater lignotuber biomass and penetrated deeper into the soil than those from central Spain. It is believed that the less favorable growth conditions (less precipitation) as well as the clear role of fire in southern California to a large degree explain the results. These data provide a foundation upon which to assess potential belowground carbon storage differences between the two regions.

Oechel W.C., Hastings S.J., Vourlitis G.L., Jenkins M.A., and Hinkson C.L. 1995. Direct Effects of $\mathrm{CO}_{2}$ in Chaparral and Mediterranean-Type Ecosystems. In: Moreno J.M., and Oechel W.C. (eds.). Global Change and Mediterranean-Type Ecosystems. Ecological Studies 117. Springer, New York, NY, pp. 58-75.

For the three, major, southern California chaparral species studied, photosynthetic acclimation to elevated $\mathrm{CO}_{2}$ was observed, possibly due to low nutrient availability and the lack of available sinks for the excess carbohydrate fixed. Asymbiotic nitrogen-fixing bacteria may have alleviated nitrogen stress in coast live oak, prolonging the initial stimulatory effects of elevated $\mathrm{CO}_{2}$ on photosynthesis early on. While an increase in WUE was observed under elevated $\mathrm{CO}_{2}$, transpiration per unit of leaf area either remained unchanged or increased. In two of the species studied, increases in leaf area under elevated $\mathrm{CO}_{2}$ resulted in greater whole plant water use and put into question any benefits in water yield from chaparral water sheds under elevated $\mathrm{CO}_{2}$.

Reece C.F., Krupa S.V., Jager H.-J., Roberts S.W., Hastings S.J., and Oechel W.C. 1995. Evaluating the effects of elevated levels of atmospheric trace gases on herbs and shrubs: a prototype dual array field exposures system. Environmental Pollution 90:25-31.

A Free air $\mathrm{CO}_{2}$ enrichment (FACE) system was developed as an economical alternative to the available technology to researchers. Highlighting the design was a dual array system with the outer array intended to reduced $\mathrm{CO}_{2}$ use, a major cost in 
all FACE experiments. Good control and spatial homogeneity of the desired trace gas $\left(\mathrm{CO}_{2}\right)$ was achieved with the anticipation that the out array which vented ambient air as an air curtain would reduce $\mathrm{CO}_{2}$ usage.

Rillig M.C., and Allen M.F. 1999. What is the role of arbuscular mycorrhizal fungi in plants to ecosystem responses to elevated atmospheric $\mathrm{CO}_{2}$ ? Mycorrhiza 9: 1-8.

This paper highlights the importance of taking a holistic, process orientated research approach when looking at belowground responses to elevated $\mathrm{CO}_{2}$. A specific plant species-fungus interaction may or may not be modified by $\mathrm{CO}_{2}$ treatment. The point is made that a hierarchical approach with emphasis on changes in processes should be the bottom line when evaluating the potential role of mycorrhizal fungi in evaluating ecosystems responses to elevated $\mathrm{CO}_{2}$ and not simply species specific observations.

Rillig M.C., Wright S.F., Allen M.F., and Field C.B. 1999. Rise in carbon dioxide changes soil structure. Nature 400: 628.

A number of field studies of the effect of elevated $\mathrm{CO}_{2}$ have resulted in an increase in soil aggregation, specifically, an increase in glomalin concentrations. This observation is important in it represents an increase in carbon sequestration by the ecosystem. However, the importance of this observation goes beyond absolute amounts of carbon sequestered as an additional effect may be a decline in soil degradation and erosion under elevated $\mathrm{CO}_{2}$ such that current soil carbon stocks are stabilized.

Rillig M. C., Treseder K.K, and Allen M.F. 2001. Global change and mycorrhizal fungi. In: Mycorrhizal Ecology, van der Heijden M., and Sanders I. (eds), Ecological Studies Series, Springer Verlag.

Roberts S., Oechel W.C., Hastings S.J, and Bryant P. 1998. A field fumigation system for elevated carbon dioxide exposure in chaparral vegetation. Functional Ecology 12: 708-719.

Further development of a Free Air $\mathrm{CO}_{2}$ enrichment system was accomplished focusing on a reliable, inexpensive $\mathrm{CO}_{2}$ delivery system and straightforward algorithms that require little tuning or adjustment by an operator. The performance of the system was on par with other systems and spatially homogenous within a 11 meter diameter portion of a 16-meter ring. Differences in photosynthesis and water stress of Adenostoma fasciculatum was found within 6 weeks of treatment.

Stylinski, C.D., Oechel W.C., Gamon J.A.,Tissue D.T., Miglietta F., and Raschi A. 2000. Effects of lifelong $\mathrm{CO}_{2}$ enrichment on carboxylation and light utilization of 
Quercus pubescens Willd. examined with gas exchange, biochemistry and optical techniques. Plant Cell Environment 23:1353-1362.

After lifelong exposure to elevated atmospheric $\mathrm{CO}_{2}$ from a natural spring, Quercus pubescens was not found to down regulate its rate of net photosynthesis. Maximum assimilation at saturating $\mathrm{CO}_{2}$, electron transport capacity, and Rubisco content, activity and carboxylation capacity were identical in $\mathrm{CO}_{2}$ exposed and control plants. As these measurements were made early in the growing season when sink strength was likely the greatest, extrapolation to greater biomass at the per meter ground area basis is not necessarily valid.

Treseder K. K. and Allen M.F. 2000. Black boxes and missing sinks: Fungi in global change research. Mycological Research 104:1281-1283.

The point is made that to often, focus on ecosystem response to elevated $\mathrm{CO}_{2}$ is made on the plant, either ignoring below ground processes, or treating them as a black box. It is pointed out that recent advances in genetic analyses and stable isotope techniques can be combined with traditional approaches to identify the fungal groups and their role in ecosystem function. With mounting evidence that soils may forma sink for $\mathrm{C}$ under elevated $\mathrm{CO}_{2}$ to help mitigate global warming undermines the importance of integrating research of mycologists and ecosystem ecologists.

Treseder K. K., and Allen M.F. 2000. Mycorrhizal fungi have a potential role in soil carbon storage under elevated $\mathrm{CO}_{2}$ and nitrogen deposition. New Phytologist 147: 189-200.

A significant fraction of soil organic matter and below-ground biomass is comprised of mycorrhizal tissue. Current literature indicates that ecosystems exposed to elevated $\mathrm{CO}_{2}$ result in increased carbon sequestration by mycorrhizal fungi, potentially serving as a negative feeback on the rise in atmospheric $\mathrm{CO}_{2}$ levels. Preliminary studies indicated that $\mathrm{N}$ deposition might increase turnover rates of fungal tissue and diminish or eliminate the sequestration potential of mycrorrhizal hypae. Studies on potential changes in mycorrhizal community composition under elevated $\mathrm{CO}_{2}$ and increased $\mathrm{N}$ are critical if we are to have a predicative capability with respect to ecosystems response to increases in $\mathrm{CO}_{2}$ and nitrogen.

In manuscript:

Baraldi R., Oechel W.C., Hastings S.J., Bryant B., and Miglietta F. Recent growth in atmospheric $\mathrm{CO}_{2}$ is sufficient to increase biogenic volatile hydrocarbon (BVOCs ) 
emissions in Mediterranean-type ecosystems and provide a pathway for negative feedback on regional warming. (in manuscript).

Cheng Y., Oechel W.C., Hastings S.J., Bryant P., and Major J. The effect of Elevated $\mathrm{CO}_{2}$ on carbon flux of Southern California chaparral by using Free Air $\mathrm{CO}_{2}$ Enrichment. (in manuscript).

Cheng Y, Oechel W.C., Hastings S.J., Major J., and Bryant P. Ecosystem carbon flux under elevated $\mathrm{CO}_{2}$ by $\mathrm{CO}_{2}$ LT Chambers in southern California chaparral. (in manuscript).

Harazono Y., Vourlitis G.L., Roberts S.W., Hastings S.J, and Oechel W. C. Eddy covariance measurements of net $\mathrm{CO}_{2}$ flux and energy balance of chaparral ecosystems across a fire-induced age gradient. (in manuscript).

Harazono, Y., Hastings S.J., Vourlitis G.L., and Oechel W.C. Differences of physical and physiological characteristics of chaparral vegetation of a canopy level within different ages. (in manuscript).

Hinkson C., Oechel W.C., Roberts S., Miglietta F., and Raschi A. Photosynthesis and water-use of a Mediterranean oak after long-term $\mathrm{CO}_{2}$ enrichment by a natural $\mathrm{CO}_{2}$ spring. (in manuscript).

Ibanez I., Oechel W.C., Hastings S.J., and Tissue D. Patterns of and controls on photosynthetic acclimation to long term exposure to elevated $\mathrm{CO}_{2}$ in a semi-arid Mediterranean-type shrubland ecosystem. (in manuscript).

Langsford D.H. and Oechel W.C. Diurnal and seasonal water potential patterns among and within Ceanothus greggii shrubs in southern California chaparral. (in manuscript).

Oechel W.C., and Jenkins M.A. 1995. Interactions of pre-industrial and predicted future atmospheric $\mathrm{CO}_{2}$ concentrations and drought on growth and photosynthesis of chaparral shrubs. (in manuscript).

Treseder K.K., Cheng Y., Allen M.F., and Oechel, W.C. ${ }^{13} \mathrm{C}$ tracers of carbon allocation to roots under a $\mathrm{CO}_{2}$ gradient in intact southern Californian chaparral. (in manuscript).

Presentations:

Allen M.F., Karen O., Klironomos J., Rillig M., and Harney S. Fungal responses to elevated $\mathrm{CO}_{2}$ in Mediterranean-type ecosystems. Ecological Society of America 84th Annual Meeting, August 8-12, 1999.

Anderson A.E., and William, K.S. Effects of elevated atmospheric $\mathrm{CO}_{2}$ on a southern California chaparral arthropod community. ESA 1997 annual meeting, 10-14 August, Albuquerque, New Mexico. Suppl. Bull. Ecol. Soc. of America. 78(3): 127.

Anderson A.E., and K.S. Williams. Effects of elevated $\mathrm{CO}_{2}$ on southern California chaparral arthropod populations: Initial results. MEDECOS VIII, October 18-26, 1997, San Diego, California. p 14. 
Anderson A.E., and Williams K.S. The effect of atmosphric $\mathrm{CO}_{2}$ concentrations on chaparral arthropod populations. Ecological Society of America 84th Annual Meeting, August 8-12, 1999.

Baraldi R., Rapparini F., Miglietta F., Oechel W.C., Hastings S.J. and Cheng Y. Effects of elevated $\mathrm{CO}_{2}$ concentrations on terpenoid emission from chaparral ecosystems. An International Workshop, Montpellier, France, 22-23 March 2001.

Cheng Y., Oechel W.C., Hastings S.J., Major J., Bryant P., and Qian H. Ecosystem carbon flux under elevated $\mathrm{CO}_{2}$ by FACE technique in southern California chaparral. Ecological Society of America 86 ${ }^{\text {th }}$ Annual Meeting, August 6-10, 2001.

Cheng Y, Oechel W.C., Hastings S.J., Major J., and Bryant P. Ecosystem carbon flux under elevated $\mathrm{CO}_{2}$ treatment by FACE and Null Balance chamber in Southern California Chaparral. Ecological Society of America 85 ${ }^{\text {th }}$ Annual Meeting, August 6-10, 2000.

Cheng Y., Oechel W.C., Hastings S.J., Major J., and Bryant P. Plot-scaled Carbon and Water Vapor Flux measuring by $\mathrm{CO}_{2}$ LT Chambers in Southern California Chaparral. Southern California Academy of Sciences Annual Meeting May 4 - 5, 2001.

Gamon J.A., Qiu H-L., Roberts D.A., Ustin S.L., Fuentes D.A., Rahman A., Sims D., and Stylinski C.D. 1999. Water expressions from hyperspectral reflectance: implications for ecosystem flux modeling. Proceedings of 1999 Airborne Geoscience Workshop. Jet Propulsion Laboratory, Pasadena, CA.

Hinkson C.L., Oechel W.C., Miglietta F., and Raschi A. Plant- and soil-nitrogen dynamics after long-term $\mathrm{CO}_{2}$ enrichment by a natural $\mathrm{CO}_{2}$ spring. ESA 1997 annual meeting, 10-14 August, albuquerque, New Mexico. Suppl. Bull. Ecol. Soc. of America. 78(3): 101.

Ibanez I., Tissue D., Ogle K., Hastings S.J., and Oechel W.C. Long-term photosynthetic response of southern California chaparral to $\mathrm{CO}_{2}$. Ecological Society of America 84th Annual Meeting, August 8-12, 1999.

Moreno, J.M., Cruz A., and Oechel W.C. 1997. Biometric relationships in two lignotuberous species from Spain and California. MEDECOS VIII, October 18-26, 1997, San Diego, California. p 48.

Oechel W.C. 1994. Effects of global change on unmanaged ecosystems. Review. Dutch National Program. Maastricht December 1994.

Oechel W.C., and Moreno J.M. Symposium Organizers. MEDECOS/GCTE Symposium on Effects of Global Change on Mediterranean-type Ecosystems. Vina Del Mar, Chile. October 23-29, 1994.

Oechel W.C., Hinkson C., and Miglietta F. $\mathrm{CO}_{2}$ and climate effects on photosynthesis and productivity of Mediterranean-type shrublands and oak woodlands. MEDECOS/GCTE Symposium on Effects of Global Change on Mediterraneantype Ecosystems. Vina Del Mar, Chile. October 23-29, 1994.

Oechel W.C, Hastings S.J, Vourlitis G., Bryant P., and Zulueta R. Predicting the effects of global change from long-term chaparral research at the SDSU Sky Oaks 
Biological Field Station. Ecological Society of America 84th Annual Meeting, August 8-12, 1999.

Ogle K., Oechel W.C., Bryant P., and Hastings S.J. Leaf area, shoot elongation and inflorescence response of Adenostoma fasiculatum dominated chaparral to elevated $\mathrm{CO}_{2}$ using FACE and $\mathrm{CO}_{2} \mathrm{LT}$ approaches. MEDECOS VIII, October 18-26, 1997 , San Diego, California. p 52.

Ogle K., Tissue D., Ibanez I., Hastings S. and Oechel W. 1999. Leaf level response of chamise chaparral grown under pre-industrial, ambient and elevated $\mathrm{CO}_{2}$ concentrations. Ecological Society of America $84^{\text {th }}$ Annual Meeting, Spokane, WA, August 8-12, 1999.

Stylinski C.D., Oechel, W.C., Miglietta, F., Raschi, A., and Ustin, S. Effects of longterm $\mathrm{CO}_{2}$ enrichment on chlorophyll concentration and leaf reflectance of three woody species. . ESA 1997 annual meeting, 10-14 August, albuquerque, New Mexico. Suppl. Bull. Ecol. Soc. of America. 78(3): 101.

Stylinski,C.D., Oechel W.C., Raschi A., and Gamon J.A. Effects of long-term $\mathrm{CO}_{2}$ enrichment on narrow-band leaf reflectance, PSII light-use efficiency and photosynthesis of querus pubescens trees. MEDECOS VIII, October 18-26, 1997 , San Diego, California. p 65.

Stylinski C.D., Gamon J.A., and Oechel W.C. Seasonal variations in narrow-wave ban reflectance, photoprotective pigments, and photosynthesis of several evergreen chaparral species. Ecological Society of America 84th Annual Meeting, August 8$12,1999$.

Thesis/Dissertation:

Heffernan L.C. 1996. Measuring the effect of increased levels of $\mathrm{CO}_{2}$ on soil bacteria in a Mediterranean type ecosystem. M.Sc. Thesis, San Diego State University.

Williams-Anderson A.E. Effects of Whole-Ecosystem Atmospheric Carbon Dioxide Concentration Manipulation on Abundance and Species Diversity of Arthropods in a Post-fire Chaparral Community, Ph. D. Dissertation, UC-Davis and San Diego State University. 
Initial progress

For the period

September 1, 1993 to August 31, 1996

\title{
RESPONSE OF MEDITERRANEAN-TYPE ECOSYSTEMS TO ELEVATED ATMOSPHERIC CO2 AND ASSOCIATED CLIMATE CHANGE
}

\author{
Walter C. Oechel \\ INTRODUCTION AND BACKGROUND
}

There has been uncertainty and discussion of the potential response of unmanaged ecosystems to elevated $\mathrm{CO}_{2}$ (Bazzaz, 1990; Graham et al., 1990; Idso et al., 1991; Körner et al., 1992; Melillo et al., 1990; Mooney et al., 1991; Norby et al., 1986; Shaver et al., 1992). This stems in part from the range of responses found in laboratory and field situations. In the salt marsh environment, long-term stimulation of photosynthesis and productivity by elevated $\mathrm{CO}_{2}$ have been found (Drake, 1992) although recently homeostatic adjustment ("down regulation") has been reported (Jacob et al., 1995). In the arctic, photosynthesis and net ecosystem carbon flux quickly adjust to elevated $\mathrm{CO}_{2}$ so that at the leaf level, photosynthesis exhibits complete homeostatic adjustment within three weeks, and ecosystem-level homeostatic adjustment of net $\mathrm{CO}_{2}$ flux begins within the first season of exposure (Grulke et al., 1990) and is complete within the third year (Oechel et al., 1994). 
Loblolly pine cultivated in pots in the field show little response to elevated $\mathrm{CO}_{2}$ after the first year when grown under nutrient levels which simulate field nutrient supply rates (Strain and Thomas, 1992).

Under sufficiently warm temperatures, ecosystems may respond positively to elevated $\mathrm{CO}_{2}$ over prolonged periods (Drake, 1992) and this may be the case for some ecosystems. However, in other cases nutrients appear to limit the potential long-term response to elevated $\mathrm{CO}_{2}$ (Strain, 1991; Owensby et al., 1990; Bazzaz, 1990; Norby et al., 1986; Körner et al., 1992; Larigauderie et al., 1988). While increased nitrogen fixation has been demonstrated at elevated $\mathrm{CO}_{2}$ (Bentley, 1992), the interacting effects of nutrient immobilization and nutrient fixation under field conditions have not been fully examined.

Ecosystems may be simultaneously limited by a large number of factors (Billings, 1952) that vary over time. It is possible for water, temperature, $\mathrm{CO}_{2}$, and nutrients to simultaneously limit ecosystem productivity and carbon storage in certain ecosystems (Chapin, 1991; Field et al., 1992; Mooney et al., 1991; Graham, et al., 1990). In other ecosystems, these factors may limit productivity at various time scales (Oechel and Billings, 1992). Time scales can be critical in consideration of response to elevated $\mathrm{CO}_{2}$. For example, it is possible for $\mathrm{CO}_{2}$ to be limiting in the short term (minutes to hours), but not over longer time scales (Tissue and Oechel, 1987; Grulke et al., 1990, and Oechel et al. 1994) when nutrients may 
become more limiting (Shaver et al., 1992). However, at still longer time scales, the nutrient mass or species composition may change, again allowing response to elevated $\mathrm{CO}_{2}$ (Oechel and Billings, 1992).

Both resources and processes can limit ecosystem response to elevated $\mathrm{CO}_{2}$, and the importance of these factors can change over time. In short time scales, leaf biochemistry and physiology may control ecosystem photosynthetic rates (Drake, 1992; Strain and Thomas, 1992). At longer time scales, morphology (Woodward, 1987), growth, species composition, vegetation, and evolution can be important (Graham, et al., 1990; Oechel and Billings 1992).

The response of ecosystems to elevated $\mathrm{CO}_{2}$ can be viewed at a number of different time scales. In this research, we were primarily interested in the response of ecosystems to elevated $\mathrm{CO}_{2}$ which occurs over minutes to decades or even centuries. The short-term response helps in understanding mechanisms and feedbacks significant in controlling responses at seasonal to decadal time scales (Sage et al., 1989; Stitt, 1991a,b).

For terrestrial plants, atmospheric $\mathrm{CO}_{2}$ concentration appears to universally limit short-term photosynthesis rates (Drake, 1992). As a result, an increase in $\mathrm{CO}_{2}$ concentration of the air results in a rapid short-term increase in photosynthesis. However, long-term photosynthetic response to elevated atmospheric $\mathrm{CO}_{2}$ concentration is much more variable. This is due to the fact that there are additional 
controls and feedbacks on long-term photosynthetic response to elevated $\mathrm{CO}_{2}$ compared to short-term responses. Short-term response (minutes) depends almost entirely on fast-acting processes (e.g. leaf biochemistry and physiology). Longerterm responses depend on these levels of organization, and on other longer-term processes including anatomical, growth, demographic, community, and ecosystem levels of organization. Over even longer time scales, ecotypic, dispersal, and genetic factors can begin to influence the plant and ecosystem response to elevated $\mathrm{CO}_{2}$ (Oechel and Billings, 1992). These adjustments can be homeostatic; that is, they can tend to maintain ecosystem photosynthetic rates at similar levels, or they can potentially further exaggerate the effect of elevated $\mathrm{CO}_{2}$ on photosynthesis by increasing the plant or ecosystem response to elevated $\mathrm{CO}_{2}$ (as would occur if extant species were replaced by those better able to utilize additional atmospheric $\mathrm{CO}_{2}$ ).

\section{Chaparral}

Chaparral and other Mediterranean-type ecosystems were selected for study since they are good model ecosystems in which to investigate the controls on homeostatic adjustment of photosynthesis to elevated $\mathrm{CO}_{2}$. These systems are predicted to respond to elevated $\mathrm{CO}_{2}$ due to their warm, water-limited, and nutrientmoderate status (Oechel et al., 1995, Strain and Thomas, 1995). Preliminary data indicate a range of potential homeostatic adjustments to elevated $\mathrm{CO}_{2}$ that allow tests of $\mathrm{CO}_{2}$ and moisture interactions. Chaparral forms a valuable comparison to 
other ecosystems which have been, or are being investigated including arctic (Oechel et al., 1992; Oechel and Billings, 1992), salt marsh (Drake, 1992), prairie (Owensby, 1990), eastern deciduous forest (Norby, 1986), conifer forests (Strain and Thomas 1992; Ball et al., 1992) and deserts (planned, Seeman et al. pers. comm.).

In this research, we concentrated primarily on the homeostatic processes and controls which affect the response of $\mathrm{CO}_{2}$ and $\mathrm{H}_{2} \mathrm{O}$ flux to altered atmospheric $\mathrm{CO}_{2}$ and moisture availabilities. To adequately address and understand limitations on responses to elevated $\mathrm{CO}_{2}$, it is necessary to investigate the range of processes and mechanisms which can feed back on, and affect photosynthesis. Biochemical, physiological, growth, demographic, community, and ecosystem processes were studied. Other factors will affect ecosystem response to $\mathrm{CO}_{2}$ in the chaparral. Moisture availability, a significant limiting factor in Mediterranean-type ecosystems (MTEs), which is affected by $\mathrm{CO}_{2}$ level, was investigated. Effects on and feedbacks with other environmental factors including nutrient mass and supply rates were also studied.

Tested were the effects of $\mathrm{CO}_{2}$ concentration from nominally pre-industrial $\mathrm{CO}_{2}$ concentrations to more than double current $\mathrm{CO}_{2}(250$ to $750 \mathrm{ppm})$ in $100 \mathrm{ppm}$ $\mathrm{CO}_{2}$ increments. The interacting effects on the growth, water yield, and trace gas flux of chaparral shrub vegetation was measured. 
Higher atmospheric $\mathrm{CO}_{2}$ has the potential to increase plant growth in a variety of ways including greater photosynthesis (McGuire et al., 1995), relief of nutrient stress (through various mechanisms including increased nutrient-use efficiency, symbiotic and assymbiotic nitrogen fixation, and higher nutrient uptake by the roots) (Norby et al., 1986), relief of drought stress Tolley et al., (1991) and increased water yields (due to greater water-use efficiency) (Wigley and Jones, 1985), depression of respiration (Poorter et al., 1992), or delay of leaf senescence (Tissue and Oechel, 1987; Curtis et al., 1989). The mechanisms that increase wateruse efficiency and decrease transpiration should promote growth in arid and semiarid ecosystems. However, there is great uncertainty as to whether these mechanisms operate for prolonged periods in natural ecosystems. If elevated $\mathrm{CO}_{2}$ does stimulate the growth of woody vegetation, this could lead to long-term increases in carbon storage in terrestrial ecosystems.

\section{RESULTS 1993-1996}

\section{$\mathrm{CO}_{2} \mathrm{LT}$ Chambers}

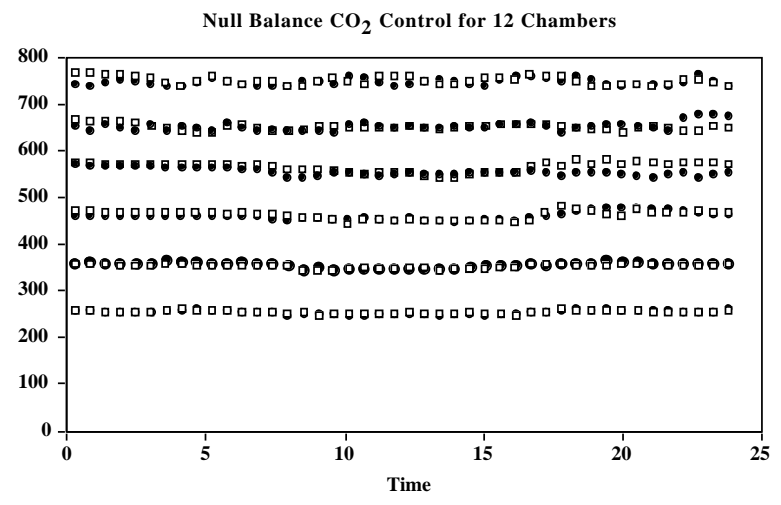


Figure 1. $\mathrm{CO}_{2}$ control in the twelve $\mathrm{CO}_{2} \mathrm{LT}$ chambers operating at 250 to $750 \mathrm{ppm} \mathrm{CO} 2$ with two chambers at each concentration (February 16, 1996).

The null-balance $\mathrm{CO}_{2} \mathrm{LT}$ chambers designed for $\underline{\mathrm{CO}_{2}}$ control and measurement under ambient Light and controlled Temperature (Tissue and Oechel, 1987; Grulke et al., 1990; Oechel et al., 1992) were adapted for use in the chaparral. The chambers were placed on chaparral regenerating after fire, and initial measurements of the effects of $\mathrm{CO}_{2}$ concentration on net ecosystem flux were made. As the plants regrew, the original $\mathrm{CO}_{2} \mathrm{LT}$ chambers were redesigned and expanded to $2 \times 2 \times 2$ meters high, the cooling capacity was increased, and the air handling hardware was improved. In addition, "blow out panels" were installed to allow the chamber sides to be opened in the event of a system failure, thereby preventing over or under temperature conditions. The original control and data logging software was completely re-written in "Lab View" software. A color image of the current chamber configuration can be viewed at the San Diego Union Tribune web site at: "http://www.uniontrib.com" under "Science" or at: "http://www.uniontrib.com:80/science_city/environment/environment960228/climat e2.html."

The current experimental design is for 12 chambers, running two each at 250 to $750 \mathrm{ppm} \mathrm{CO}_{2}$ in $100 \mathrm{ppm}$ increments. Regression analysis of response to $\mathrm{CO}_{2}$ concentration is being used. A water stress (75\% of ambient precipitation) is 
planned for one-half of the chambers. Precipitation is collected in equal area collectors and routed to the chambers in the amount of actual precipitation.
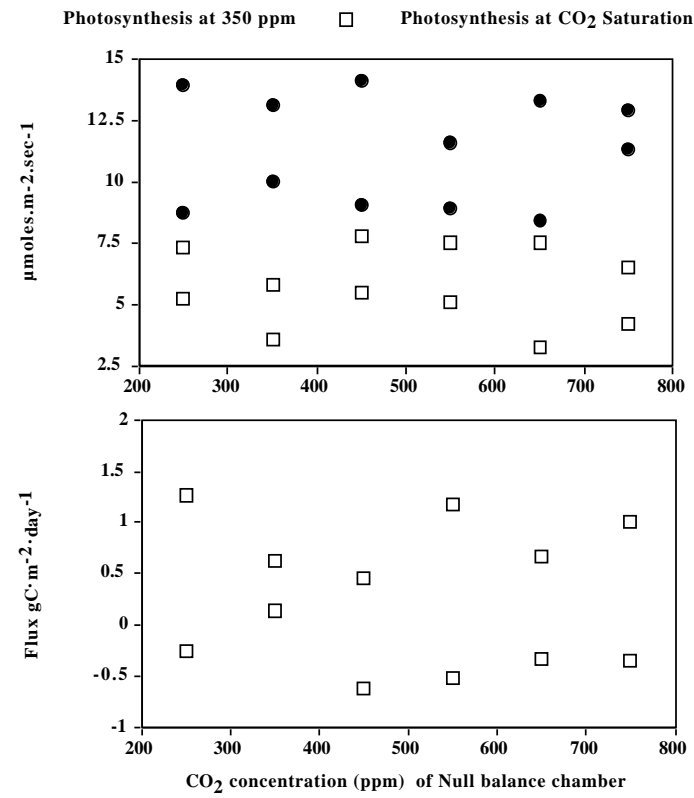

Figure. 2. Patterns of photosynthesis at ambient and saturating photosynthesis (top) and net ecosystem $\mathrm{CO}_{2}$ flux for chamber pairs assigned to differing subsequent $\mathrm{CO}_{2}$ treatment levels.

\section{Performance}

Chamber performance of $\mathrm{CO}_{2}$ (Figure 1) and temperature control following modifications is very good (Oechel et al. 1993), however, refinement of control algorithms and hardware continues. 
Prior to initiation of long-term elevated $\mathrm{CO}_{2}$ treatments in the $\mathrm{CO}_{2} \mathrm{LT}$ chambers, variability in photosynthetic rates (at ambient and saturating $\mathrm{CO}_{2}$ levels) were determined (Figure 2). Also determined were the net ecosystem $\mathrm{CO}_{2}$ fluxes. Results show no difference in any of these factors among the chambers allocated to different treatment $\mathrm{CO}_{2}$ levels. This gave confidence that future differences in carbon flux would be due to treatment effects, and not to chamber to chamber variability.

\section{$\underline{\text { Net Ecosystem } \mathrm{CO}_{2}} \underline{\text { Flux }}$}

Short-term net ecosystem $\mathrm{CO}_{2}$ flux is significantly stimulated by elevated $\mathrm{CO}_{2}$ (Figures 3 and 4). Exposure to $750 \mathrm{ppm} \mathrm{CO}_{2}$ increases net ecosystem $\mathrm{CO}_{2}$ flux by almost $80 \%$. Net midday sequestration is much more affected than is nighttime respiration. Laboratory studies indicate that long-term response to elevated $\mathrm{CO}_{2}$ will depend in part on water availability (Oechel et al., 1995; Jenkins 1993). 

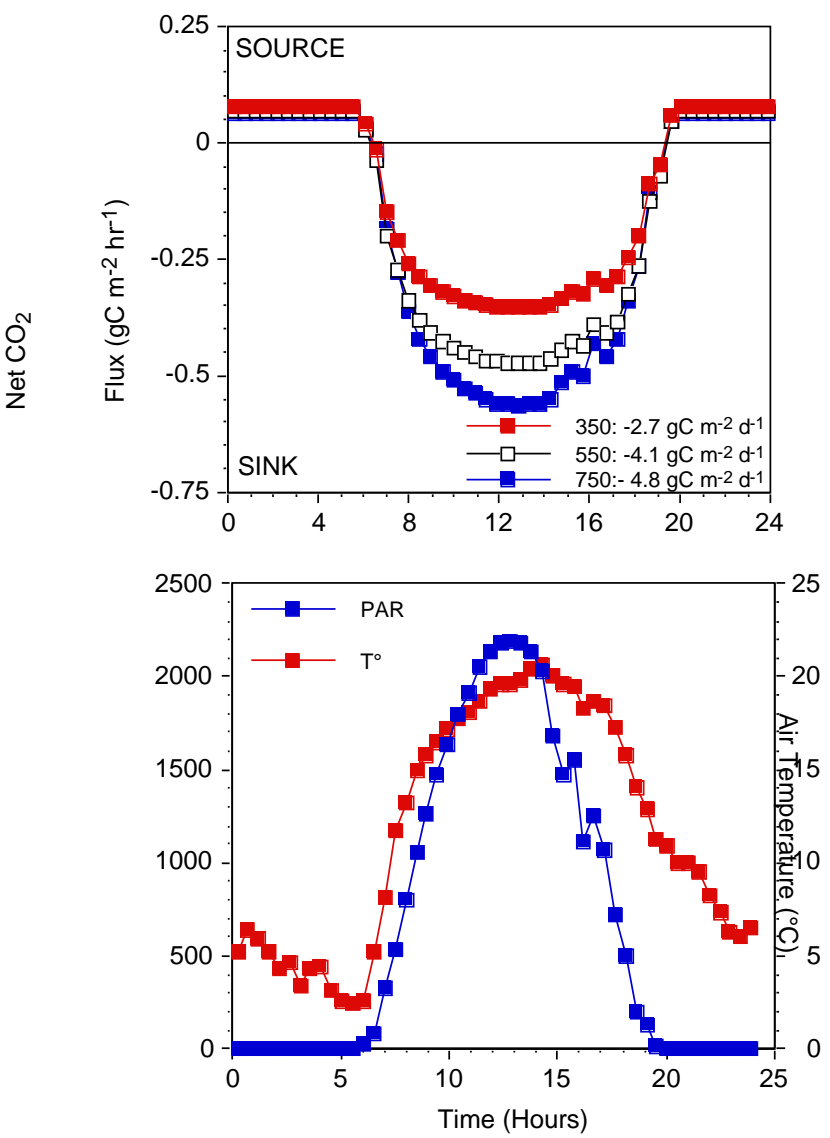

Figure 3. Diurnal net ecosystem $\mathrm{CO}_{2}$ flux at 350,550 , and $750 \mathrm{ppm} \mathrm{CO}_{2}$ and accompanying light and temperature in May 1995. Net diurnal ecosystem fluxes at $750 \mathrm{ppm} \mathrm{CO}_{2}$ were almost $80 \%$ higher than those at $350 \mathrm{ppm} \mathrm{CO}_{2}$.

Studies on the response of chaparral recovering from fire to ambient and experimentally manipulated levels of atmospheric $\mathrm{CO}_{2}(250$ to $750 \mathrm{ppm} \mathrm{CO}$ ) are being undertaken in an experimental area comprised of a mix of Adenostoma fasciculatum resprouts and Adenostoma fasciculatum and Ceanothus greggii seedlings. Water availability is typically increased immediately after fire (Hastings, Oechel, and Sionit, 1989). Due to the reduced drought following fire, reduced water 
treatments will not commence until later in the experiment as significant drought develops. This approach will allow a period of time with duplicate chamber treatments to allow replication and baseline measurements before the reduced water manipulations begin. Water treatments will include normal ambient and $75 \%$ ambient precipitation.

The use of six $\mathrm{CO}_{2}$ levels allows regression analysis of the resultant information, production of response surfaces to $\mathrm{CO}_{2}$ concentration, and avoids pseudo-replication (Hurlbert, 1984). Temperature and dew point are being maintained at contemporary ambient levels.

Photosynthesis measurements made after only 6 weeks of exposure to elevated $\mathrm{CO}_{2}$ show a strong down regulation of photosynthetic capacity (maximum photosynthetic rate) (Figure 5, top). This shows rapid photosynthetic adjustment under elevated $\mathrm{CO}_{2}$, at least under conditions of adequate winter moisture and cool winter temperatures. Despite the down regulation of photosynthesis, elevated $\mathrm{CO}_{2}$ was sufficient to convert ecosystem flux from a source to the atmosphere, to a sink during this winter period (Figure 5 bottom). 


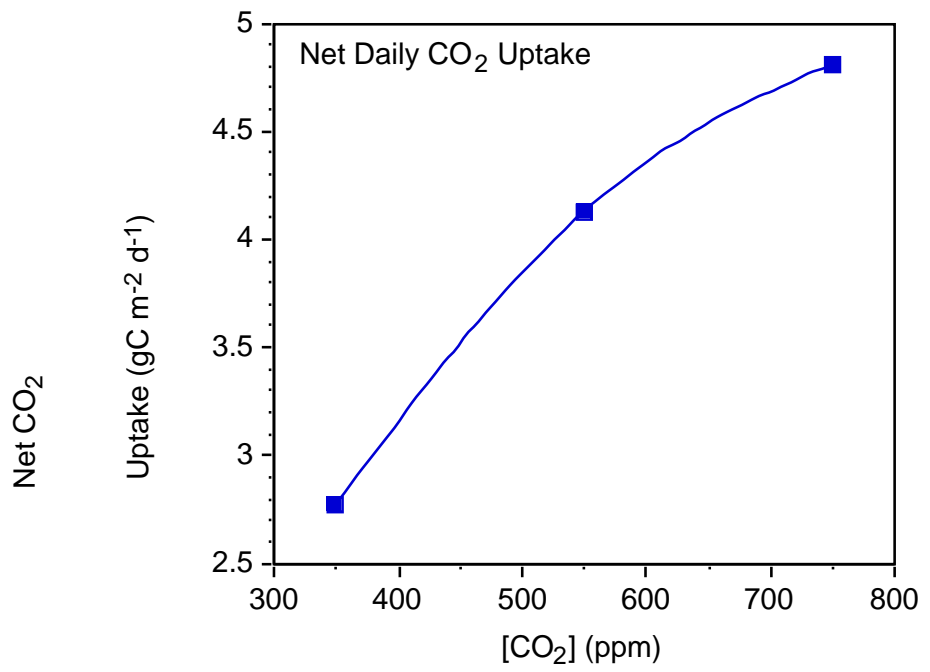

Figure 4. Short-term response of diurnal net ecosystem $\mathrm{CO}_{2}$ flux to $\mathrm{CO}_{2}$ concentration (May 1995).

\section{Free Air $\mathrm{CO}_{2}$ Enrichment (FACE)}

Obviously the size and complexity of ecosystems very nearly makes ecosystem-level studies intractable, and yet this very complexity also makes it difficult to generalize the results of laboratory or greenhouse studies to natural ecosystems. We are using FACE technology to validate the results from our $\mathrm{CO}_{2} \mathrm{LT}$ chambers, and to treat sufficient area to allow adequate sampling for belowground processes. FACE systems use a chamberless array of stand pipes which release $\mathrm{CO}_{2}$ into a study plot based on wind direction and speed. Although the $\mathrm{CO}_{2}$ consumption is high compared to other technologies, FACE systems allow $\mathrm{CO}_{2}$ control over relatively large areas, in this case, $177 \mathrm{~m}^{2}$, and eliminates chamber effects. 
The FACE approach is one of the least invasive methods for treating natural systems with elevated $\mathrm{CO}_{2}$, as well as being the most cost effective when figured on a cost/area basis (Kimball, 1992). It also treats a sufficiently large area to capture many ecosystem processes of interest (e.g. plant germination, establishment, competition; most nutrient dynamics of interest; plant-microbe interactions; certain plant-insect interactions). We developed a FACE system as a validation for our $\mathrm{CO}_{2} \mathrm{LT}$ chamber study, and to provide a large enough area to allow adequate sampling for most processes of current interest. A $16 \mathrm{~m}$ FACE ring has been built and tested in conjunction with Sagar Krupa and Clive Reece of University of Minnesota (Reece et al., 1995). Subsequent refinements included further software and hardware development, movement to a single ring from the original double ring configuration to reduce possible environmental effects on wind speed or shading, and addition of a 34 ton receiver which allows us to run for 25 days without refilling. Upon completion of FACE construction, concentrations were within $\pm 20 \%$ of the set point for one-minute averages for at least $80 \%$ of the measurement period (see e.g. Hendrey et al. 1993, Table 1). Initially, control at a desired set point was accomplished by using a particular mix of algorithms and fan speeds. One algorithm predicted the mass flow of $\mathrm{CO}_{2}$ required to achieve a set point $\mathrm{CO}_{2}$ concentration based on the cross-sectional area of the ring and the wind speed. The other two algorithms used PID loops, one based on the error in meeting the $\mathrm{CO}_{2}$ set point while the other on the error of the mass flow of $\mathrm{CO}_{2}$ delivered. Only one algorithm could be used at a time. The program has been modified so that a mix of algorithms 
is used, weighted as a function of wind speed. The algorithm used is now dependent on wind speed, where each individual coefficient can be independently specified.
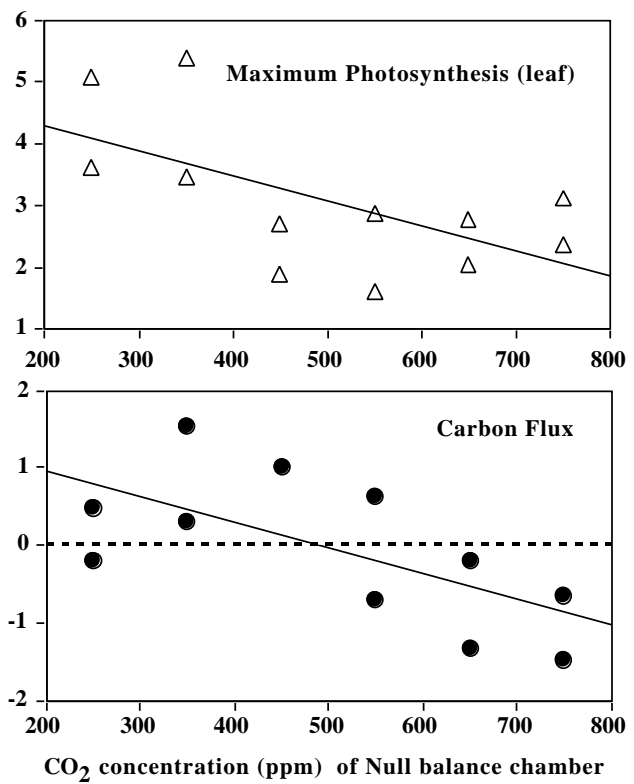

Figure 5. Net photosynthesis (maximum observed, February 17, 1996) (top) and net ecosystem flux after 6 weeks of treatment at the $\mathrm{CO}_{2}$ concentrations indicated (Feb 16, 1996).

The CRT screen output program has been rewritten to show real time value of the weight of each algorithm and coefficient as well as percent time between \pm 10 and $20 \%$ of the set point for the cumulative one minute average, and over minute averages over 10-min. 30-min., 1-hr, 6-hr, 12-hr, and 24-hr periods. The real time data analysis allows the user to receive immediate statistical analysis and evaluate how well a set of parameters is controlling. 


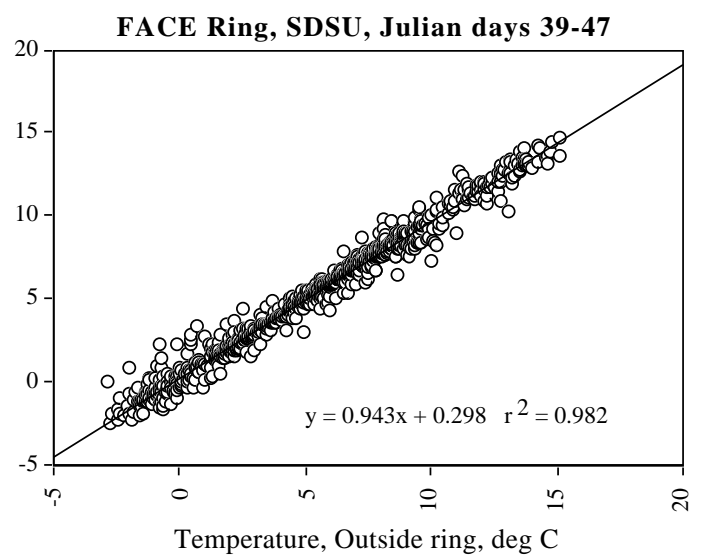

Figure 6. Average of 16 thermocouple readings every 10 min., (1,164 total readings) made at $0.7 \mathrm{~m}$ from ground in and outside the FACE ring. Control readings outside of ring were taken from a location $30 \mathrm{~m}$ from the edge of the ring.
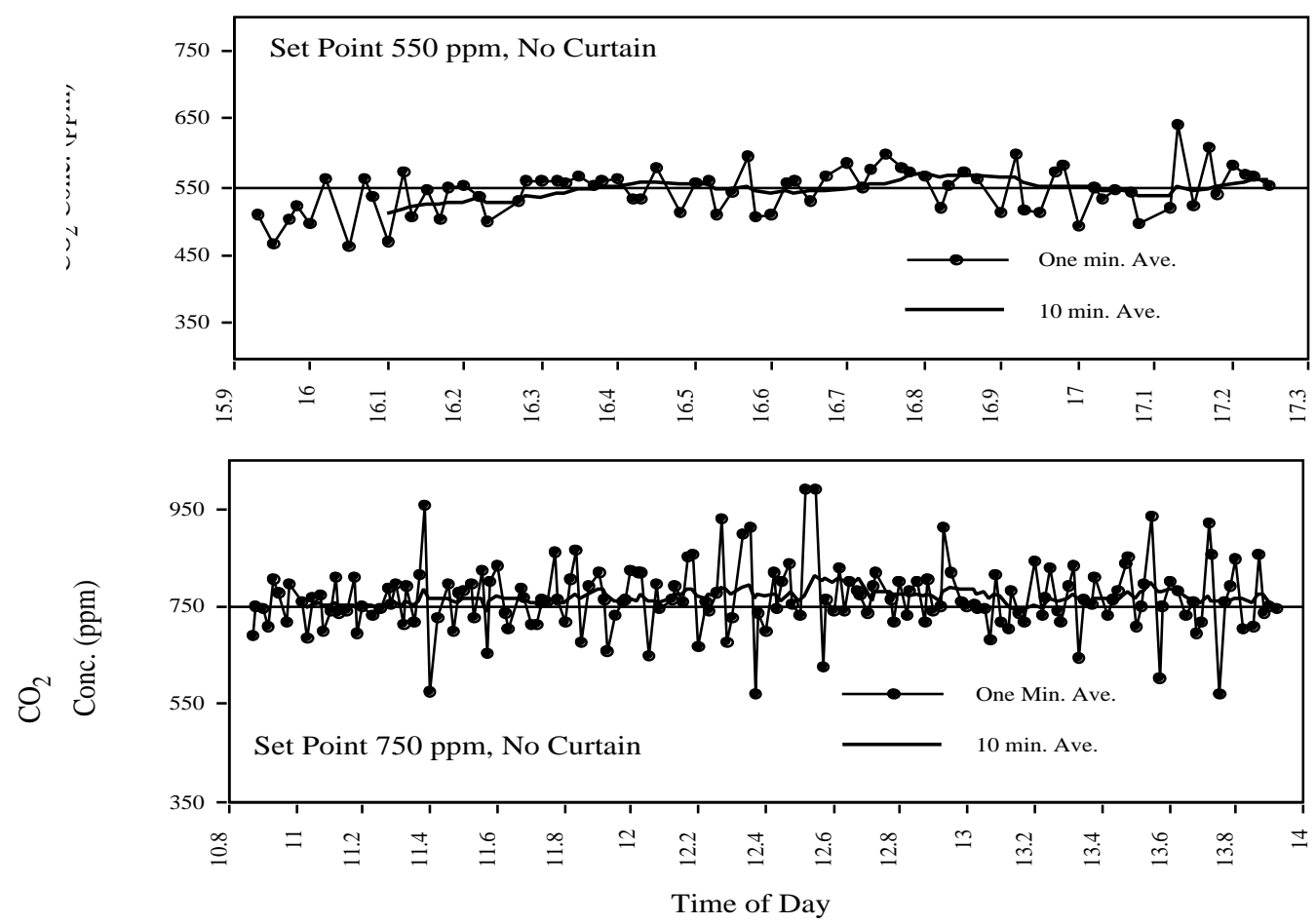
Figure 7. One minute average (circles) and ten minute running mean (solid line) $\mathrm{CO}_{2}$ concentrations within the MedFACE ring with a set point of $550 \mathrm{ppm}$ (top) and $750 \mathrm{ppm}$ $\mathrm{CO}_{2}$ (bottom). At $550 \mathrm{ppm} \mathrm{CO} 2,92 \%$ of the time the $\mathrm{CO}_{2}$ concentration in the ring was \pm $10 \%$, while $100 \%$ of the time it was $\pm 20 \%$ of the set point while at $750 \mathrm{ppm}$ percentages were 80 and 95 percent respectively. Mean control $\mathrm{CO}_{2}$ concentration was 544 and 766 ppm. Data collected at SDSU's MedCO 2 RE FACE facility (unpublished data).

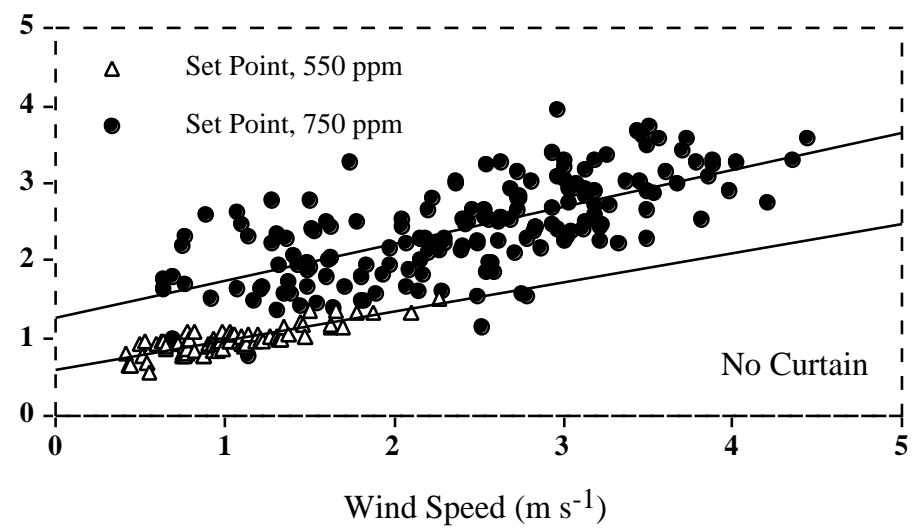

Figure 8. MedFACE $\mathrm{CO}_{2}$ consumption as a function of wind speed and $\mathrm{CO}_{2}$ set point determined in the field, winter 1995.

There is minimal affect on temperature of the FACE apparatus, even with the outer barrier plenum in place. Figure 6 shows the near 1:1 correspondence between inside and outside temperatures. There was a slight decrease inside the ring at higher temperatures (daytime) while at lower temperatures (nighttime) a slight increase. This is due to the impacts of increased wind movement during the day at 
high temperatures, and a disruption of the still, radiatively cooled air at night during still wind conditions.

This system performed very well with respect to $\mathrm{CO}_{2}$ control (Figure 7) and $\mathrm{CO}_{2}$ consumption (Figure 8). The performance was very good "at turn on" (Reece et al., 1995), and subsequently improved through hardware and software improvements described above $\mathrm{CO}_{2}$ consumption, increases with wind speed (and $\mathrm{CO}_{2}$ set point concentration) in the manner predicted (Figure 8).

In developing our MedFACE system, it was decided that the control code and construction and operation materials will be provided upon request to interested researchers, and all aspects of the system will be published in the open literature to allow maximal availability to the research community. The FACE system will complement our existing ongoing investigation of chaparral ecosystem response to elevated $\mathrm{CO}_{2}$ by validating in an open environment the results obtained using chamber technology at the same site. 
Table 1. Preliminary $\mathrm{CO}_{2}$ control and consumption data for MedFACE ring. These are initial values and reflect initial control algorithms and variable conditions during testing.

\begin{tabular}{|c|c|c|c|c|c|c|}
\hline $\begin{array}{c}\mathrm{CO}_{2} \mathrm{Set} \\
\text { Point } \\
\text { (ppm) }\end{array}$ & $\begin{array}{l}\text { Ave. } \\
\mathrm{CO}_{2} \\
\text { Conc. } \\
\text { (ppm) }\end{array}$ & SE & $\begin{array}{l}\text { Wind } \\
\text { Speed } \\
\mathrm{m} \mathrm{s}^{-1}\end{array}$ & $\begin{array}{c}\text { \% of } 1 \\
\text { min. } \\
\text { average } \\
\text { within } \\
10 \% \text { of } \\
\text { set point }\end{array}$ & $\begin{array}{c}\text { \% of } 1 \\
\text { min. } \\
\text { average } \\
\text { within } \\
20 \% \text { of } \\
\text { set point }\end{array}$ & $\begin{array}{c}\mathrm{CO}_{2} \text { use } \\
\mathrm{kg} \mathrm{CO}_{2} \\
\mathrm{~h}^{-1}\end{array}$ \\
\hline 550 & 544 & 4 & 1.0 & 92 & 100 & 64 \\
\hline 550 & 589 & 3 & 2.4 & 72 & 92 & 78 \\
\hline 550 & 560 & 5 & 2 & 72 & 95 & 136 \\
\hline 550 & 515 & 3 & 1.7 & 81 & 100 & 73 \\
\hline 550 & 575 & 5 & 0.4 & 85 & 100 & 36 \\
\hline 750 & 717 & 7 & 1.9 & 71 & 94 & 167 \\
\hline 750 & 760 & 5 & 1.9 & 78 & 96 & 136 \\
\hline 750 & 766 & 5 & 2.8 & 80 & 94 & 149 \\
\hline
\end{tabular}

\section{Baseline measurements}

Extensive measurements were made within the FACE ring and on soil beneath similar age vegetation (part of the same burn as the FACE study) in the surrounding areas with respect to soil respiration. Rates were in general similar other than one control area east of the FACE ring and situated on a south-facing slope (Figure 9). 
Soil respiration was determined using an opaque cuvette $\left(150 \mathrm{~cm}^{2}\right)$ during midday on six replicate areas including the FACE ring treatment area, and areas east and west of the FACE ring site; within the null-balance chambers; and within control plots laid out for comparison with the chambers. The respiration rates were surprisingly uniform at this time. We anticipate that the soil respiration rate will increase within the FACE ring due to increased allocation of carbon belowground. An increase in water-use efficiency, and a decrease in transpiration rate due to elevated $\mathrm{CO}_{2}$ could result in higher soil moisture which would tend to increase decomposition rates of soil organic matter and thereby further increase soil respiration rates.

Diurnal water potentials and net photosynthesis measurements were determined for A. fasciculatum in the FACE ring and in the control plot. The pattern of water stress before initiation of treatment was nearly identical in the two areas (Figure 10). Minimum values were observed at midday of $-5 \mathrm{MPa}$, and only partially recovering to $-4 \mathrm{MPa}$ in the evening. Full recovery took a number of hours when pre-dawns values of -3 to $-2.5 \mathrm{MPa}$ were recorded.

After 5 weeks of treatment at elevated $\mathrm{CO}_{2}$, there is an indication of improved moisture status under the elevated $\mathrm{CO}_{2}$ (Figure 10). This is consistent with predictions of initially reduced leaf and canopy transpiration rates at elevated $\mathrm{CO}_{2}$. (Jenkins, 1993; Oechel et al., 1995). 


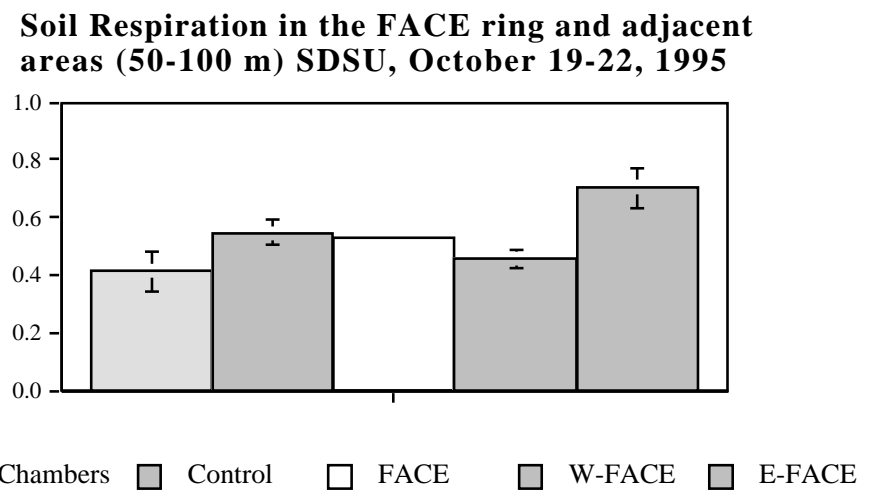

Figure 9. Soil respiration in and around the FACE ring site.

Before initiation of the $\mathrm{CO}_{2}$ treatment, photosynthesis was slightly higher in the plants found within the FACE ring (1.5 to $1.8 \mu$ moles $/ \mathrm{m}^{2} / \mathrm{sec}$ ) compared to those found in the control area (ca. $1 \mu \mathrm{mole} / \mathrm{m}^{2} / \mathrm{sec}$ ). Photosynthesis and water potential data indicate a low level of metabolic activity in both regions at this time. 


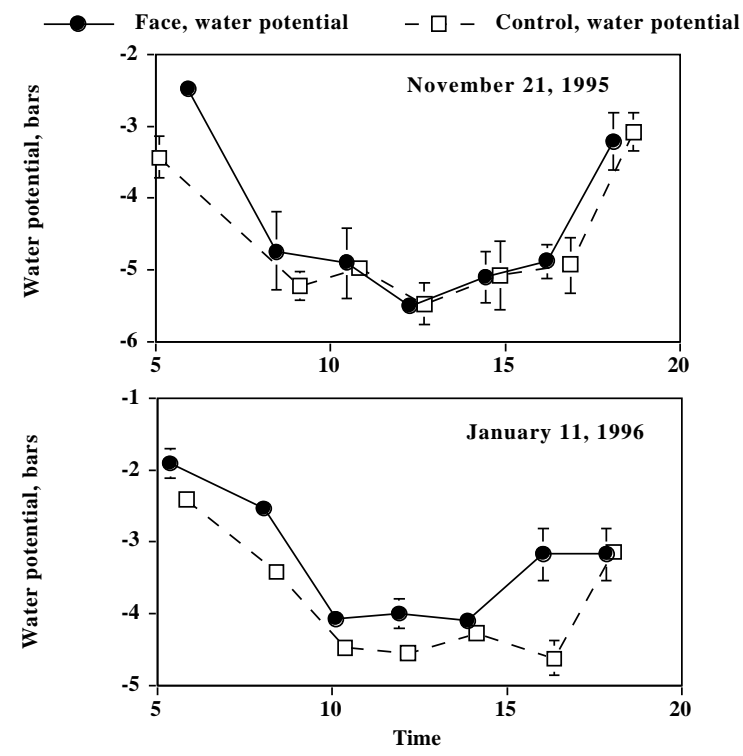

Figure 10. Average water potential for six plants within the FACE ring and six in a designated control area [from November 21, 1995 (before the start of the continuous treatment) and on January 11 (after about 5 weeks of elevated $\mathrm{CO}_{2}$ treatment)]. Standard errors are shown on the figure.

Measurement of photosynthetic rates after initiation of continuous $\mathrm{CO}_{2}$ treatment on December 1, 1995, indicates rapid and significant down regulation of photosynthesis after only $51 / 2$ weeks of elevated $\mathrm{CO}_{2}$ treatment (Figure 11), even with the improvement of water status within the treatment area.

\section{Long-term Responses to Elevated $\mathrm{CO}_{2}$ : Research at the Laiatico $\mathrm{CO}_{2}$ Springs}

An opportunity to study long-term effects of elevated $\mathrm{CO}_{2}$ on ecosystems exists at a natural $\mathrm{CO}_{2}$ spring near Laiatico, Tuscany in northern Italy. This site has been visited and found to exhibit a large area of $\mathrm{CO}_{2}$ enrichment of over 0.6 ha as a 
result of a $\mathrm{CO}_{2}$ release estimated at over 8 tons per day. While some sulfur is present in the $\mathrm{CO}_{2}$, sulfur release is low and is estimated at less than 60 grams of sulfur per day in 8 tons of $\mathrm{CO}_{2}$. Previous studies indicate that the sulfur should pose little or no biological effect at a moderate distance from the $\mathrm{CO}_{2}$ vent and over most of the area enriched. In addition, since most of the $\mathrm{CO}_{2}$ is emitted from one major vent, it is possible to remove most of the sulfur from the $\mathrm{CO}_{2}$ emissions should this be deemed prudent. No symptoms of sulfur $\left(\mathrm{SO}_{2}, \mathrm{H}_{2} \mathrm{~S}\right)$ toxicity were noted at the site. Additional analyses are needed, however, including soil $\mathrm{pH}$ and leaf sulfur content.

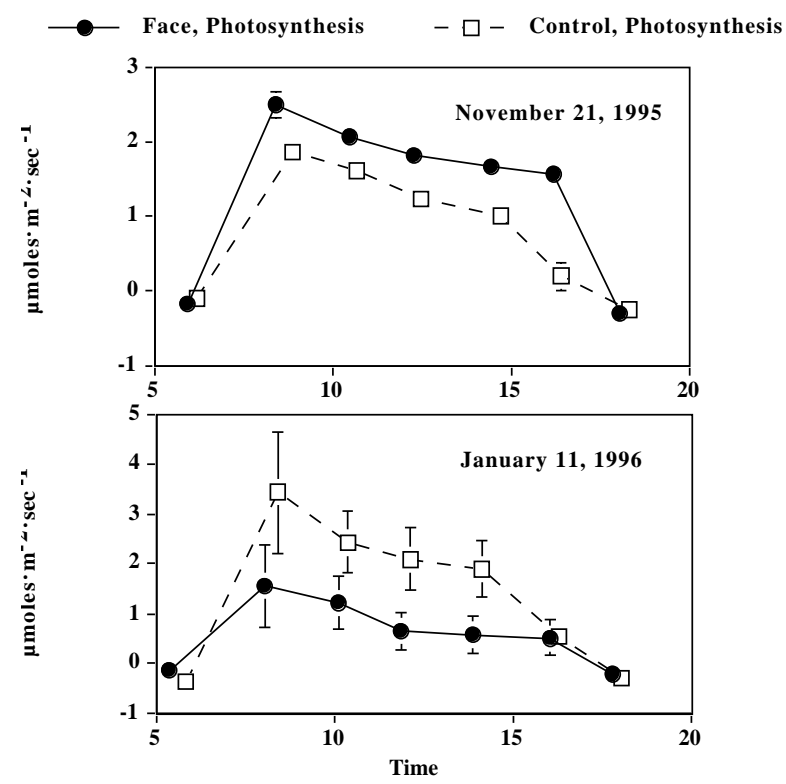

Figure 11. Average net photosynthesis for six plants within the FACE ring and six in a designated control area. From November 21, 1995 (before the start of the continuous 
treatment) (top) and on January 11 (after about 5 weeks of elevated $\mathrm{CO}_{2}$ treatment) (bottom). Standard errors are shown on the figure.

$\mathrm{CO}_{2}$ concentrations were measured to be on average more than $2,500 \mathrm{ppm}$ at $5 \mathrm{~m}$ from the origin of the transect (about $10 \mathrm{~m}$ from the spring) to less than 600 ppm at $80 \mathrm{~m}$ to the east of the spring. A north-south transect, $20 \mathrm{~m}$ to the east of the spring ranged from $>2,000 \mathrm{ppm} \mathrm{CO}_{2}$ to $<550 \mathrm{ppm} \mathrm{CO}_{2}$ at $40 \mathrm{~m}$ (Figure 12). At the top of the canopy, leaf samples were analyzed for ${ }^{14} \mathrm{C}$ content to yield average $\mathrm{CO}_{2}$ concentration (Figure 13). The concentrations were lower than those reported near the ground (Figures 12 and 13), but were still significantly elevated.

The vegetation of the area is a coppiced oak forest approximately 25 years of age containing typical Mediterranean mattoral and forest species including Quercus ilex, Q. pubescens, Pistacia lentiscus, Arbutus linedo, and several nitrogen-fixing species. There appear to be good control areas and control watersheds in the region. The area is apparently one of strong carbon sequestration, and one of increased sequestration potential with a longer coppicing interval.

The elevated $\mathrm{CO}_{2}$ springs in northern Italy allow the study of the effects of very long-term $\mathrm{CO}_{2}$ exposure (probably over millennia). The period of past enrichment can be estimated by ${ }^{14} \mathrm{C}$ dating of wood and soil organic material. Since the $\mathrm{CO}_{2}$ originates from subvention of ancient carbonate rocks, its emission is ${ }^{14} \mathrm{C}$ depleted. This estimate will allow easy determination of the average concentration 
of $\mathrm{CO}_{2}$ experienced by recent plant material, as well as indicating the minimum period of enrichment.

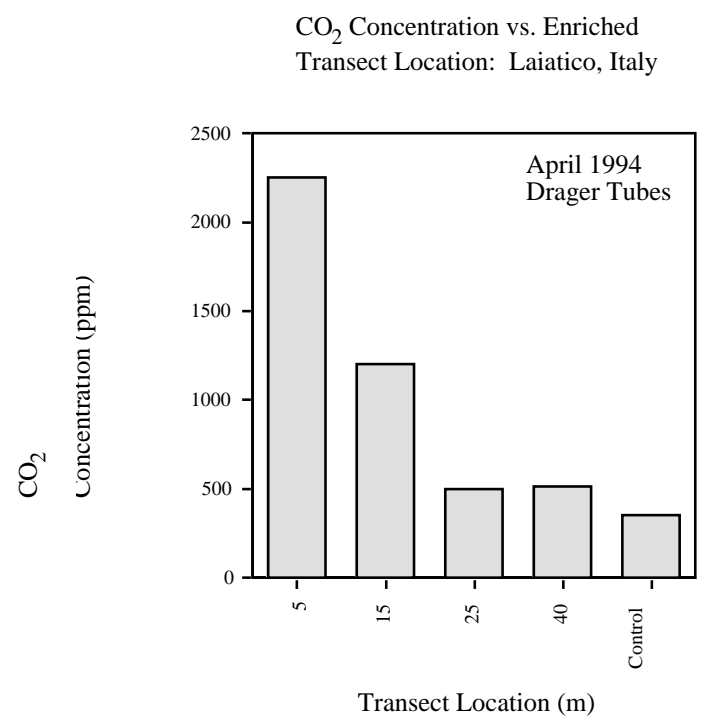

Figure 12. $\mathrm{CO}_{2}$ concentration along a north-south transect at Laiatico $\mathrm{CO}_{2}$ springs in Laiatico, Italy. $\mathrm{CO}_{2}$ concentrations were generally averaged over 4-6 hours on one-two days in April 1994. $\mathrm{CO}_{2}$ concentrations were determined by Draeger diffusion tubes and by infrared gas analysis. Good agreement was found between Draeger tubes and integration of IRGA measurements when averaged over the same period in the field (Miglietta et al., unpubl). 


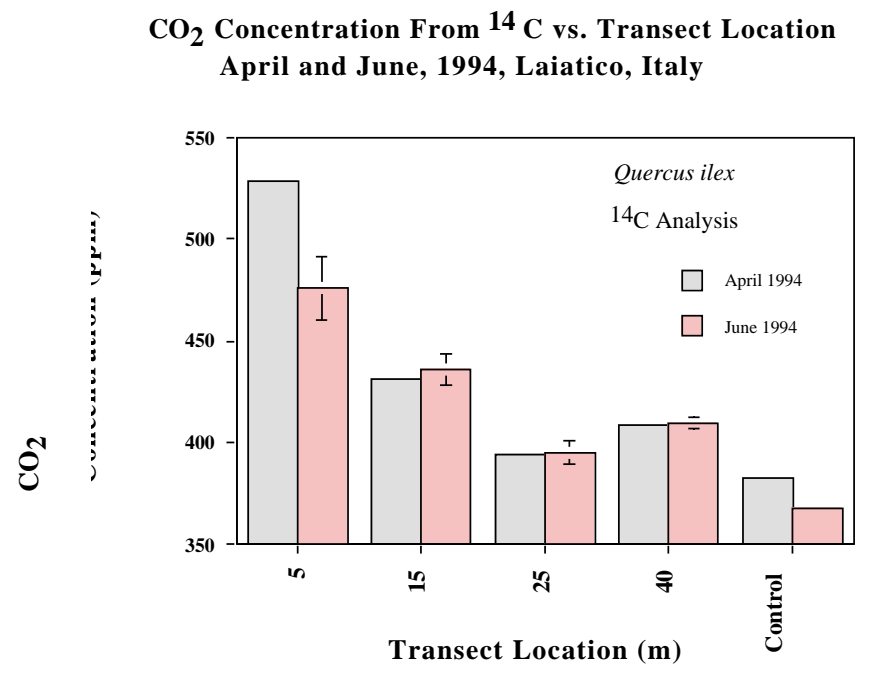

Figure 13. $\mathrm{CO}_{2}$ concentration from the top of the plant canopy along a northsouth transect at Laiatico $\mathrm{CO}_{2}$ springs in Laiatico, Italy determined from ${ }^{14} \mathrm{C}$ analysis.

Initial measurements were made, including $\mathrm{A}: \mathrm{C}_{\mathrm{i}}$ curves of photosynthesis, and leaf samples were taken for nutrient analysis. Initial nutrient analysis of the leaves indicates that leaf total nitrogen concentration significantly decreased with proximity to the $\mathrm{CO}_{2}$ spring (increasing $\mathrm{CO}_{2}$ concentration; Figure 14).

Preliminary investigation indicates significant "down regulation" and homeostatic adjustment of Quercus ilex to elevated $\mathrm{CO}_{2}$ (Figure 15). "Down regulation" of $A: C_{i}$ curves is of the order $15 \mathrm{~m}>25 \mathrm{~m}>40 \mathrm{~m}$, and is in the direction to homeostatic adjustment. However, in June 1994, the homeostatic adjustment was totally relaxed (Figure 16). Reasons are uncertain, but formation of new leaf tissue 
and depletion of carbohydrate reserves during the spring growth flush may have accounted for the loss of "down regulation." This is fruitful area for insight into the controls on homeostatic adjustment to elevated $\mathrm{CO}_{2}$, and the interactions with other factors.

It is premature to attempt to estimate the combined effects of "down regulation" of $\mathrm{A}: \mathrm{C}_{\mathrm{i}}$ curves, elevated $\mathrm{CO}_{2}$, and changes in leaf area on plant and ecosystem carbon flux and carbon sequestration. It is clear, however, that feedbacks and adjustments are occurring at the physiological level. The use of these springs should give a real-world look at possible physio-logical, nutrient flux, genetic, and landscape responses to long-term $\mathrm{CO}_{2}$ enrichment in native forest tree and shrub species.

Total Nitrogen Concentration of Leaves

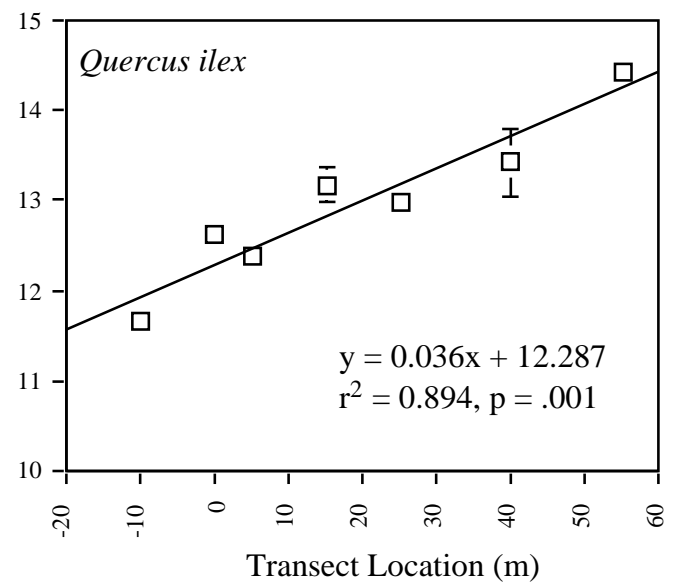


Figure 14. Nutrient concentration in Quercus ilex with distance from $\mathrm{CO}_{2}$ source at Laiatico $\mathrm{CO}_{2}$ springs at Laiatico, Italy. Distances given are relative to an arbitrary starting point, approximately $20 \mathrm{~m}$ from the $\mathrm{CO}_{2}$ spring. Distance from the $\mathrm{CO}_{2}$ vent is approximately $20 \mathrm{~m}$ plus the value indicated. Total nitrogen concentration was determined using TKN extraction and a Technicon auto-analyzer (Bran \& Luebbe Analyzing Technologies, Elmsford, N.Y.). Symbols represent the mean of 12 samples (three leaf ages, two branches per tree, two trees per transect location). Means and standard errors are shown ( $\mathrm{n}=2$ trees per transect location). Data were analyzed using a one-way ANOVA. Since there were non-significant differences in nitrogen concentration between years for each tree, the data from each of the three years of leaf age classes were pooled for each tree (Hinkson, Oechel, and Miglietta, unpubl. data).

Evaluation of predawn and midday tissue water potentials indicate no substantial improvement of water status from elevated $\mathrm{CO}_{2}$ in either Summer or Fall. Again, while the data are preliminary, it appears as though decreases in transpiration rate on a leaf area basis are at least offset by increases in leaf area index (Figure 17) in areas of elevated $\mathrm{CO}_{2}$ concentrations. 
Assimilation vs. Internal CO 2

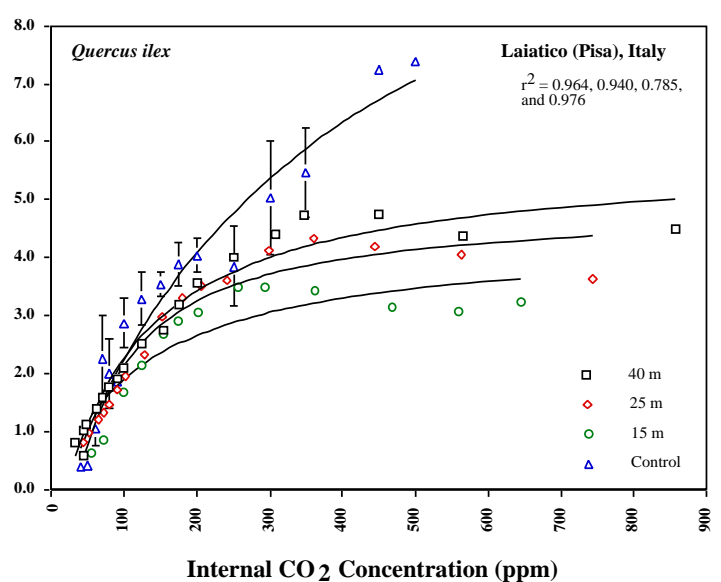

Figure 15. Assimilation versus internal $\mathrm{CO}_{2}$ concentration of Quercus ilex at the Laiatico $\mathrm{CO}_{2}$ spring in Laiatico, Italy in April 1994. Standard error bars reflect variability among three individuals under ambient $\mathrm{CO}_{2}$ conditions at 60,80 , and 100 $\mathrm{m}$ locations south along the north-south transect running $20 \mathrm{~m}$ east of the spring. Individuals measured at 40, 25, and $15 \mathrm{~m}$ locations north along the north-south transect were under enriched $\mathrm{CO}_{2}$ concentrations, the $15 \mathrm{~m}$ location being closest to the $\mathrm{CO}_{2}$ source and the most enriched.

Assimilation vs. Internal CO 2

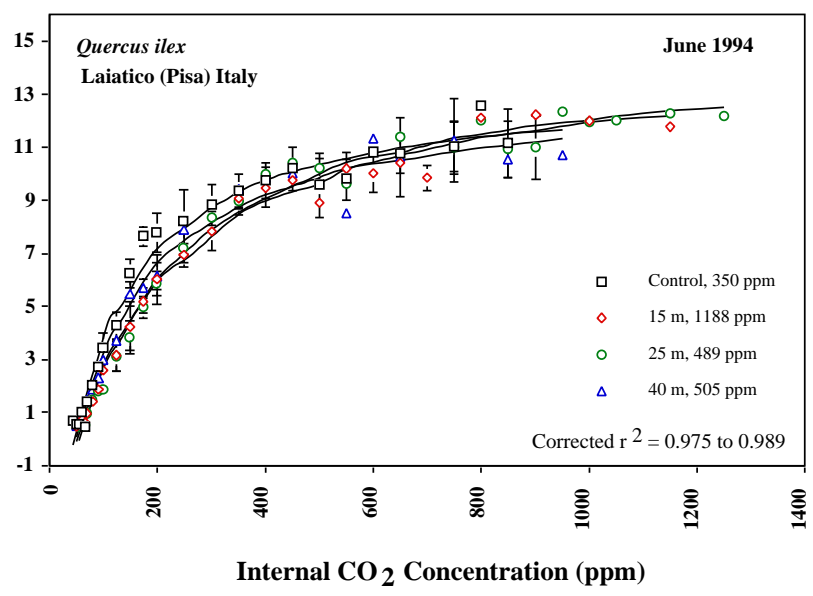


Figure 16: Assimilation versus internal $\mathrm{CO}_{2}$ concentration of Quercus ilex at the Laiatico $\mathrm{CO}_{2}$ spring in Laiatico, Italy in June, 1994 (bottom). Standard error bars reflect variability among three individuals under ambient $\mathrm{CO}_{2}$ conditions at 60,80 , and $100 \mathrm{~m}$ locations south along the north-south transect running $20 \mathrm{~m}$ east of the spring. Individuals measured at 40,25, and $15 \mathrm{~m}$ locations north along the north-south transect were under enriched $\mathrm{CO}_{2}$ concentrations, the $15 \mathrm{~m}$ location being closest to the $\mathrm{CO}_{2}$ source and the most enriched.

The effect of intermittent stimulation in photosynthesis, and spreading of the $\mathrm{C}: \mathrm{N}$ ratio appears to increase the growth rate as indicated by internode elongation and ring widths (Hinkson, Oechel, and Miglietta, unpublished data).

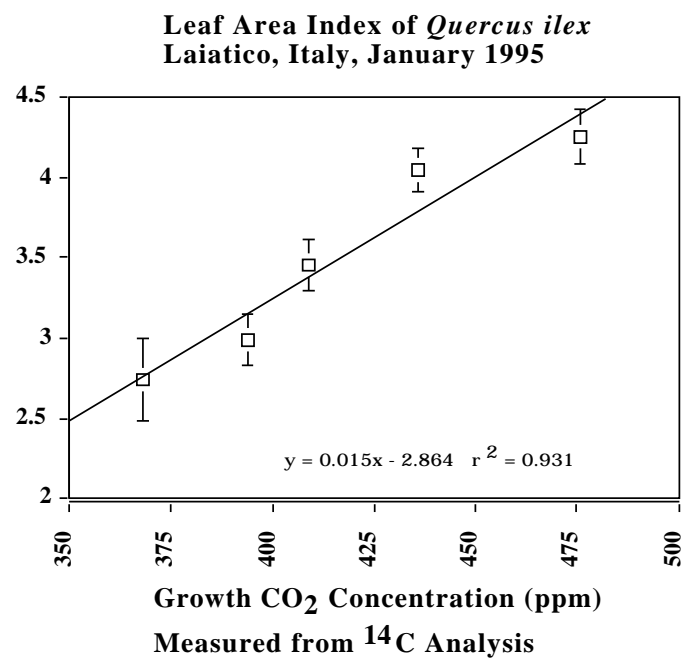

Figure 17. Relationship between leaf area index and $\mathrm{CO}_{2}$ concentration as measured by ${ }^{14} \mathrm{C}$ dilution. 


\section{LITERATURE CITED AND OTHER RELEVANT LITERATURE}

Amthor, J.S. 1989. Respiration and crop productivity. Springer-Verlag, New York. 215 pp.

Amthor, J.S. 1991. Respiration in a future, higher-CO2 world. Plant Cell Env. 14: 1320.

Amthor, J.S., G.W. Koch, and A.J. Bloom. 1992. $\mathrm{CO}_{2}$ inhibits respiration in leaves of Rumex crispus L. Plant Physiology. 98: 574-581.

Arnon, D.I. 1949. Copper enzymes in isolated chloroplasts. Polyphenoloxydase in Beta vulgaris. Plant Physiol. 24: 1-15.

Azcon Bieto, J., and C.B. Osmond. 1983. Relationship between photosynthesis and respiration. Plant Physiology. 71: 574-581.

Ball, J.T., D.W. Johnson, B.R. Strain, R.Thomas, and R.F. Walker. 1992. Effects of $\mathrm{CO}_{2}$ on Forests. Second Annual Report. Desert Research Institute, Reno, NV.

Bartholemew, G. A. 1986. The role of natural history in contemporary biology. Bioscience. 36: 324-329.

Black, C.H. 1987. Biomass, nitrogen, and phosphorus accumulation over a southern California fire cycle chronosequence. pp. 445-458. In: J.D. Tenhunen, F.M. Catarino, O.L. Lange, and W.C. Oechel (eds.). Plant Response to Stress-Functional Analysis in Mediterranean Ecosystems. NATO ASI Series, Vol. G15, Springer-Verlag, New York.

Bazzaz, F.A. 1990. The response of natural ecosystems to the rising global $\mathrm{CO}_{2}$ levels. Ann. Rev. Ecol. Syst. 21: 167-196.

Bentley, B. 1992. The effects of increased atmospheric $\mathrm{CO}_{2}$ on Lupinus and its herbivores. Am. J. Bot Supple. 79: 59-60.

Billings, W.D. 1952. The environmental complex in relation to plant growth and distribution. Q. Rev. Biol. 27: 251-265.

Binkley, D., and P. Matson. 1983. Ion exchange resin bag method for assessing forest soil nitrogen availability. Soil Science Society of America Journal. 47: 10501052.

Bonde, T.A., B.T. Christensen, and C.C. Cerri. 1992. Dynamics of soil organic matter as reflected by natural ${ }^{13} \mathrm{C}$ abundance in particle size fractions of forested and cultivated oxisols. Soil Biology and Biochemistry. 24: 275-277.

Bottner, P., Couteaux, M.M., and V.R. Vallejo. 1995. Soil organic matter in Mediterranean-type ecosystems and global climatic changes: A case study-the soils of the Mediterranean basin.. In: J.M. Moreno and W.C. Oechel (eds). 1995. Anticipated effects of a changing global environment on Mediterranean-type ecosystems. Springer Verlag Publishers, New York. 527 pp.

Bowes, G. 1991. Growth at elevated $\mathrm{CO}_{2}$ : photosynthetic responses mediated through Rubisco. Plant, Cell and Environment. 14: 795-806. 
Bowes, G. 1993. Facing the inevitable: plants and increasing atmospheric $\mathrm{CO}_{2}$. Ann. Rev Plant Physiol Plant Mol Biol. 44: 309-332.

Bradford, M.M. 1976. A rapid and sensitive method for the quantification of microgram quantities of protein utilizing the principle of protein-dye binding. Anal Biochem. 72: 248-254.

Bugbee, B. and O. Monje. 1992. The limits of crop productivity. BioScience. 42: 494502.

Carlson, R.W. and F.A. Bazzaz. 1982. Photosynthetic and growth response to fumigation with $\mathrm{SO}_{2}$ at elevated $\mathrm{CO}_{2}$ for $\mathrm{C}_{3}$ and $\mathrm{C}_{4}$ plants. Oecologia. 54: 188-193.

Cerri, C.C., B. Volkoff, and F. Andreux. 1991. Nature and behavior of organic matter in soils under natural forest, and after deforestation, burning and cultivation, near Manaus. Forest Ecology and Management. 38: 247-257.

Chapin, F.S. III. 1991. Integrated responses of plants to stress. BioScience. 41: 29-36.

Chapin, F.S., III. 1980. The mineral nutrition of wild plants. Ann. Rev. Ecol. Syst. 11: 233-260.

Cheng, S-H and J.R. Seemann. 1996. Purification of RNA in plants with high carbohydrate contents. Methods in Molecular Biology, Humana Press, in press.

Chone, T., F. Andreux, J.C. Correa, B. Volkoff, and C.C. Cerri. 1991. Changes in organic matter in an oxisol from the central Amazonian forest during eight years as pasture, determined by ${ }^{13} \mathrm{C}$ isotopic composition. pp. 397-405. In: J. Berthelin (ed). Diversity of Environmental Biogeochemistry. Elsevier, NY.

Choo, G.M., P.G. Waterman, D.B. McKey, and J.S. Gartian. 1981. A simple enzyme assay for dry matter digestibility and its value in studying food selection by generalist herbivores. Oecologia (Berlin). 49: 170-178.

Clijsters H., and M. van Poucke (eds.). Effects of stress on photosynthesis. pp. 121-131. Martinus Nijhoff/Dr. W. Junk Publishers, The Hague.

Coyne, P.I., and G.E. Bingham. 1977. Carbon dioxide correlation with oxidant air pollution in the San Bernardino mountains of California. J. Air Pollution Control Assoc. 27: 782-784.

Cure, J.D., and B. Acock. 1986. Crop responses to carbon dioxide doubling: A literature survey. Agriculture and Forest Meteorology. 38: 127-145.

Curtis, P.S., B.G. Drake, P.W. Leadley, W.J. Arp, and D.F. Whigham. 1989. Growth and senescence in plant communities exposed to elevated $\mathrm{CO}_{2}$ concentrations on an estuarine marsh. Oecologia. 78: 20-26.

di Castri, F. Mediterranean shrublands of the world. 1981. In: F. di Castri, D.W. Goodall, and R.L. Specht (eds.). Ecosystems of the World 11: Mediterraneantype Shrublands. Elsevier Scientific Publishing Co. Amsterdam, The Netherlands. 643 pp.

Drake, B.G. 1992. The impact of rising $\mathrm{CO}_{2}$ on ecosystem production. Water, Air, and Soil Pollution. 64: 25-44. 
Drake, B.G., P.W. Leadley, W.J. Arp, D. Nassiry, and P.S. Curtis. 1989. An open top chamber for controlling $\mathrm{CO}_{2}$ concentration and measuring net ecosystem gas exchange. Functional Ecology. 3: 363-371.

Eckenrode, V.K., Arnold, J. and Meagher, R.B. 1985. Comparison of the nucleotide sequence of soybean $18 \mathrm{~S}$ rRNA with the sequence of other small subunit rRNAs. J Mol Evol. 21: 259-269.

Eduardo, B., J.F. de Paula, J.M. Melillo, C.C. Cerri, P.A. Steudler, and C. Neill. Soil organic matter characteristics in a forest and pastures of various ages in Rondonia, Brazil. Soil Biol. Biochem. (in review).

Evans, J.R. and J.R. Seemann. 1984. Differences between wheat genotypes in specific activity of RuBP carboxylase and the relationship to photosynthesis. Plant Physiol. 74: 759-765.

Evans, J.R. and J.R. Seemann. 1989. The allocation of protein nitrogen in photosynthetic apparatus: costs, consequences, and control. In: Photosynthesis, W.R. Briggs (ed.), Alan R. Liss Press, pp. 183-205.

Field, C. and Mooney, H.A. 1986. The photosynthesis-nitrogen relationship in wild plants. In: T.A. Givinish (ed.). On the Economy of Plant Form and Function. Cambridge University Press. London. pp. 25-55.

Field, C.B., Ball, T.J. and J.A. Berry. 1989. Photosynthesis: principles and field techniques. In: R.W. Pearcy, J.R. Ehleringer, H.A. Mooney, and R.W. Rundel (eds.). Plant Physiologicl Ecology. Chapman and Hall. p. 457.

Field, C.B., F.S. III Chapin, P.A. Matson, and H.A. Mooney. 1992. Responses of terrestrial ecosystems to the changing atmosphere: A resource-based approach. Ann. Rev. Ecol. Syst. 23: 201-35.

Force, D. C. 1981. Postfire insect succession in southern California chaparral. Am. Nat. 117: $575-582$.

Fowler, M.E. 1978. Nutritional value of hard water. Journal of Zoo Animal Medicine. 9: $96-98$.

Gholz, H.L., F.K. Fritz, and R.H. Waring. 1976. Leaf area difference associated with old-growth forest communities in the western Oregon Cascades. Can. J. For. Res. 6: $49-57$.

Gifford, R.M. 1979. Growth and yield of $\mathrm{CO}_{2}$-enriched wheat under water-limited conditions. Australian Journal of Plant Physiology. 6: 367-369.

Gifford, R.M. 1994. The global carbon cycle: A viewpoint on the missing sink. Australian J. of Plant Physiology. 21: 1-15.

Gluckman, C.H. and W.C. Oechel. The effects of atmospheric $\mathrm{CO}_{2}$ and drought on the nutrient relations of Quercus agrifolia. 43rd AIBS Annual Meeting, Honolulu, Hawaii. 9-13 August, 1992.

Goering, H.K. and P.J. Van Soest. 1970. Forage Fiber analyses (apparatus, reagents, procedures and some applications). Agr. Handbook No. 379, pp 1-20, USDA, Washington, D.C.

Graham, R.L., M.G. Turner, and V.H. Dale. 1990. How increasing $\mathrm{CO}_{2}$ and climate change affect forests. BioScience. 40: 575-587. 
Grier, C.L., and S.W. Running. 1977. Leaf area of mature northwestern coniferous forests: relations to site water balance. Ecology. 58: 893-899.

Grodzinski, B. 1992. Plant nutrition and growth regulation by $\mathrm{CO}_{2}$ enrichment. The effects of high $\mathrm{CO}_{2}$ on a plant are the consequence of many direct and indirect processes. BioScience. 42: 517-525.

Grulke, N.E., G.H. Riechers, W.C. Oechel, U. Hjelm, and C. Jaeger. 1990. Carbon balance in tussock tundra under ambient and elevated atmospheric $\mathrm{CO}_{2}$. Oecologia. 83: 485-494.

Hagerman, A.E., and L.G. Butler. 1978. Protein precipitation method for the quantitative determination of tannins. Journal of Agricultural and Food Chemistry. 26: 809-812.

Harazono, Y. S.J. Hastings, G.L. Vourlitis, and W.C. Oechel. 1995. Differences of physical and physiological characteristics of chaparral vegetation of a canopy level within different ages. In manuscript.

Harazono, Y. S.J. Hastings, G.L. Vourlitis, and W.C. Oechel. 1995. CO2 flux and energy budget over chaparral vegetation of different ages caused by a fire cycle chronosequence in California. In manuscript.

Harborne, J.B. 1988. Introduction to ecological biochemistry. Academic Press, New York. 356 pp.

Hastings, S.J., W.C. Oechel, and N. Sionit. 1989. Water Relations and Photosynthesis of Chaparral Resprouts and Seedlings Following Fire and Hand Clearing. In: S. Keeley (ed.). Proc. of the Symp., The California chaparral Paradigms reexamined (7-8 Nov. 1986, Los Angeles Natural History Museum, L.A.).

Hendrey, G. (ed.), 1993. The DOE/USDSA FACE Program: Goals, Objectives, and Results Through 1989. In: FACE: Free-Air CO 2 Enrichment for Plant Research in the Field, CRC Press, Boca Raton, FL, U.S.A.

Hendrey, G., K. Lewin, \& J. Nagy. 1993. Control of carbon dioxide in unconfined field plots. In: Design and Execution of Experiments on $\mathrm{CO}_{2}$ Enrichment. E. D.

Schultz and H. A. Mooney (ed.). Proceedings of a workshop held in Weidenberg, Germany, Oct. 26-30, 1992.

Hinkson, C. and W.C. Oechel. (in prep.). Asymbiotic nitrogen fixation in Quercus agrifolia and response to elevated atmospheric $\mathrm{CO}_{2}$.

Hinkson, C., and W. C. Oechel. (in prep.). Gas exchange and growth response of Quercus agrifolia to elevated atmospheric $\mathrm{CO}_{2}$.

Hinkson, C., and W. C. Oechel. 1992. Effects of elevated $\mathrm{CO}_{2}$ on the nitrogen relations of Quercus agrifolia. Symposium on Anticipated Effects of a Changing Global Environment in Mediterranean-type Ecosystems. Valencia, Spain. 13-18 September 1992.

Hochachka, P.W., and G.N. Somero. 1973. Strategies of biochemical adaptations. W.B. Saunders, Philadelphia. 358 pp. 
Hogan, K.P., A.P. Smith, and L.H. Zizka. 1991. Potential effects of elevated $\mathrm{CO}_{2}$ and changes in temperature on tropical plants. Plant, Cell and Environment. 14: 763778.

Houghton J.T., G.J Jenkins, and J.J. Ephraums (eds.). 1990. Climate Change, The IPCC Scientific Assessment. Cambridge University Press. Cambridge, U.K. 365 pp.

Hurlbert, S.H. 1984. Pseudoreplication and the design of ecological field experiments. Ecological Monographs. 54: 187-211.

Idso, S.B. and B.A. Kimball. 1991. Net photosynthesis of sour orange trees maintained in atmospheres of ambient and elevated $\mathrm{CO}_{2}$ concentration. Agricultural and Forest Meteorology. 54: 95-101.

Idso, S.B., B.A. Kimball, M.G. Anderson, and J.R. Mauney. 1987. Effects of atmospheric $\mathrm{CO}_{2}$ enrichment on plant growth: The interactive role of air temperature. Agric. Ecosystems Environ. 20: 1-10.

Jacob, J., Greitner, C. Drake, B.G. 1995. Acclimation of photosynthesis in relation to rubisco and nonstructural carbohydrate contents and in situ carboxylase activity in Scirpus olneyi grown at elevated $\mathrm{CO}_{2}$ in the field. Plant Cell and Environment. 18:(8): $875-884$.

Jenkins, M.A. 1993. Effect of atmospheric $\mathrm{CO}_{2}$ level and water stress on growth and physiology of two species of chaparral shrubs. MSc. Thesis. San Diego State University.

Jenkins, M.A., and W.C. Oechel. 1991. Effect of atmospheric $\mathrm{CO}_{2}$ level and water stress on growth and physiology of two species of chaparral shrubs. 42nd Annual Meeting of the Ecological Society of America, San Antonio, Texas. 4-8 August, 1991. Abstra

Jenkins, M.A. and W.C. Oechel. Effect of atmospheric $\mathrm{CO}_{2}$ level and water stress on growth and physiology of two species of chaparral shrubs. In prep.

Johnson, H. 1982. Needs and Opportunities in Chaparral brushlands. In: C.E. Conrad and W.C. Oechel (eds.). Dynamics and Management of Mediterranean-type Ecosystems. Pacific Southwest Forest and Range Experiment Station. General Technical Report PSW-58.

Keeley, J. and S. Keeley. 1988. Chaparral. In: M.G. Barbour and W.C. Billings (eds.). North American Terrestrial Vegetation. Cambridge Univ. Press. 434 pp.

Kimball, B.A. 1983. Carbon dioxide and agricultural yield: an assemblage and analysis of 430 prior observations. Agronomy Journal. 75: 779-788.

Kimball, B.A. 1992. Cost comparisons among free-air $\mathrm{CO}_{2}$ enrichment, open-top chamber, and sunlit controlled-environment chamber methods of $\mathrm{CO}_{2}$ exposure. Critical Reviews in Plant Sciences 11: 265-270. Also pp. 265-270 in G.R. Hendrey (ed.) FACE: Free-Air $\mathrm{CO}_{2}$ Enrichment for Plant Research in the Field. CRC Press, Boca Raton, FL.

Kobza, J. and Seemann, J.R. 1988. Mechanisms for light-dependent regulation of ribulose-1,5-bisphosphate carboxylase activity and photosynthesis in intact leaves. Proc. Natl. Acad. Sci. (USA). 85: 3815-3819. 
Körner, C., and J.A., Arnone III. 1992. Responses to elevated carbon dioxide in artificial tropical ecosystems. Science. 257: 1672-1675.

Kosko, B. 1993. Fuzzy thinking: the new science of fuzzy logic. New York: Hyperion.

Kramer, P.J., and T.T. Kozlowski. 1979. Physiology of Woody Plants. Academic Press, New York. 811 pp.

Krapp, A., B. Hofmann, C. Schafer, and M. Stitt. 1993. Regulation of the expression of rbcS and other photosynthetic genes by carbohydrates: A mechanism for the sink-regulation of photosynthesis? The Plant Journal. 3: 817-828.

Krapp, A., W.P. Quick, and M. Stitt. 1991. Rubisco, other Calvin cycle enzymes and chlorophyll decrease when glucose is supplied to mature spinach leaves via the transpiration stream. Planta. 186: 58-69.

Krebbers, E., Seurinck, J., Herdies, L., Cashmore, A.R. and Timko, M.P. 1988. Four genes in two diverged subfamilies encode the ribulose-1,5-bisphosphate carboxylase small subunit polypeptides of Arabidopsis thaliana. Plant Mol Biol. 11: $745-759$.

Larigauderie, A., D.W. Hilbert, and W.C. Oechel. 1988. Effect of $\mathrm{CO}_{2}$ enrichment and nitrogen availability on resource acquisition and resource allocation processes in a grass, Bromus mollis. Oecologia. 77: 544-549.

le Houerou, H.N. 1981. Man and ecosystems. In: F. di Castri, D.W. Goodall, and R.L. Specht (eds.). Ecosystems of the World 11: Mediterranean-type Shrublands. Elsevier Scientific Publishing Co. Amsterdam, The Netherlands. 643 pp.

Leutwiler, L.S., Meyerowitz, E.M. and Tobin, E.M. 1986. Structure and xpression of three light harvesting chlorophyll a/b-binding protein genes in Arabidopsis thaliana. Nucleic Acids Res. 14: 4051-4061.

Lindroth, R. L., K. K. Kinney, \& C. L. Platz. 1993. Responses of deciduous trees to elevated atmospheric $\mathrm{CO}_{2}$ : productivity, phytochemistry, and insect performance. Ecology. 74: 763-777.

Loomis, R.S., and Lafitte, H.R. 1987. The carbon economy of a maize crop exposed to elevated $\mathrm{CO}_{2}$ concentrations and water stress, as determined from elemental analyses. Field Crops Research. 17: 63-74.

Luxmoore, R.J. 1981. $\mathrm{CO}_{2}$ and phytomass. BioScience. 31: 626.

Martin, A., A. Mariotti, J. Balesdent, P. Lavelle, and R. Vuattoux. 1990. Estimate of organic matter turnover rate in a savanna soil by $\partial 13 \mathrm{C}$ natural abundance measurements. Soil Biology and Biochemistry. 22: 517-523.

McGuire, A.D., Melillo, J.M. and L.A. Joyce. 1995. The role of nitrogen in the response of forest net primary production to elevated atmospheric carbon dioxide. Ann. Rev. Ecol. Syst. 26: 473-503.

Melillo, J.M., J.D. Aber, A.E. Linkins, A. Ricca, B. Fry, and K.J. Nadelhoffer. 1989. Carbon and nitrogen dynamics along the decay continuum: Plant litter to soil organic matter. Plant and Soil. 115: 189-198.

Melillo, J.M., J.D. Aber, and J.F. Muratore. 1982. The influence of substrate quality on leaf litter decay in a northern hardwood forest. Ecology. 63: 621-626. 
Melillo, J.M., T.V. Callaghan, F.I. Woodward, E. Salati, and S.K. Sinha. 1990. Effects on Ecosystems. In: J.T. Houghton G.J. Jenkins, And J.J. Ephraums (eds.). 1990. Climate Change, The IPCC Scientific Assessment. Cambridge University Press. Cambridge, U.K. 365 pp.

Mills, J. N. 1985. Plant-herbivore dynamics during early postfire years in a southern California chamise chaparral stand. Doctoral dissertation. San Diego State University \& University of California Davis.

Mitchell, J.F.B., S. Manabe, V. Meleshko, and T. Tokioka. 1990. Equilibrium climate change and its implications for the future. In: J.T. Houghton, G.J Jenkins, and J.J. Ephraums (eds.). 1990. Climate Change, The IPCC Scientific Assessment. Cambridge, U.K. 365 pp.

Moldau, H., and M. Rahi. 1983. Enhancement of maintenance respiration under water stress. In: R. Marcelle, H. Clijsters, and M. van Pouche (eds.). Effects of stress on photosynthesis. pp. 121-131. Martinus Nijhoff/Dr. W. Junk Publishers, The Hague.

Moldau, H., J. Sober, and M. Rahi. 1980. Components of dark respiration in bean under conditions of a water deficit. Soviet Plant Physiology. 27: 1-6.

Mooney, H.A., B.G. Drake, R.J. Luxmoore, W.C. Oechel, and L.F. Pitelka. 1991. Predicting ecosystem responses to elevated $\mathrm{CO}_{2}$ Concentrations. BioScience. 41: 96-104.

Moore, B.D., M. Hackett, J.R. Seemann. 1994. Hamamelitol purification, identification by electrospray ionization mass spectrometry, and quantification in plant leaves. Planta. in press.

Moore, B.D., Sharkey, T.D., Kobza, J. and Seemann, J.R. 1992. Identification and levels of 2'-carboxyarabinitol in leaves. Plant Physiol. 99: 1546-1550.

Moreno, J.M. and W.C. Oechel (eds). 1995. Anticipated effects of a changing global environment on Mediterranean-type ecosystems. Springer Verlag Publishers, New York. 527 pp.

Moreno, J.M., and W.C. Oechel. 1991a. Fire intensity and herbivory effects on postfire resprouting of Adenostoma fasciculatum in southern California chaparral. Oecologia. 85: 429-433.

Moreno, J.M., and W.C. Oechel. 1991b. Fire intensity effects on the germination of shrub and herbs in southern California chaparral. Ecology. 72: 1993-2004.

Moreno, J.M., S.J. Hastings, and W.C. Oechel. Photosynthesis and burl TNC content of resprouts following fire in southern California chaparral. J. Range Management. (submmitted).

Nairn, C.J., Winesett, L. and Ferl, R.J. 1988. Nucleotide sequence of an actin gene from Arabidopsis thaliana. Gene. 65: 247-257.

Neill, C., M.C. Piccolo, P.A. Steudler, J.M. Melillo, B.J. Feigl, and C.C. Cerri. 1995. Nitrogen dynamics in soils of forests and active pastures in the western Brazilian Amazon Basin. Soil Biology and biochem. 27:1167-1175. 
Norby, R.J., E.G. O'Neill, and R.J. Luxmoore. 1986. Effects of atmospheric CO2 enrichment on the growth and mineral nutrition of Quercus alba seedlings in nutrient-poor soil. Plant Physiol. 82: 83-89.

Oberbauer, S.F., N. Sionit, S.J. Hastings, and W.C. Oechel. 1986 Effects of CO2 enrichment and nutrition on growth, photosynthesis and nutrient concentration of Alaskan tundra species. Can. J. Bot. 64: 2993-2998.

Oechel, W.C. 1991. Effects of global climate and atmospheric change on the structure and function of Mediterranean shrub ecosystems and associated forest ecotones in California. Progress report to Southern California Edison for the period January 1, 1990 to December 31, 1990. Submitted July 1991.

Oechel, W.C. S.J. Hastings, G.L. Vourlitis, M.A. Jenkins, and C.L. Hinkson. Direct effects of $\mathrm{CO}_{2}$ in chaparral and Mediterranean-type ecosystems. In: J.M. Moreno and W.C. Oechel (eds). 1995. Anticipated effects of a changing global enviornment on Mediterranean-type ecosystems. Springer Verlag Publishers, New York. 527 pp.

Oechel, W.C. 1995. Response of Mediterranean-type Ecosystems to elevated atmospheric $\mathrm{CO}_{2}$ and Associated Climate Change. In: Program for Ecosystem Research. Research Summaries. Jerry Elwood, Program Manager. Office of Health and Environmental Research. Reserach Summaries. Jerry Elwood, Program Manager. Office of Health and Environmental Research, Office of Energy Research, Department of Energy. 75 pp.

Oechel, W.C. and M.A. Jenkins. 1995. Interactions of pre-industrial and predicted future atmospheric $\mathrm{CO}_{2}$ concentrations and drought on growth and photosynthesis of chaparral shrubs. In manuscript.

Oechel, W.C., and B. Strain. 1985. Response of native species and ecosystems. In: Direct Effects of Increasing Carbon Dioxide on Vegetation. Department of Energy DOE/ER-0238.

Oechel, W.C., and G.H. Riechers. Impacts of increasing $\mathrm{CO}_{2}$ on natural vegetation, particularly the tundra. Proceedings of Climate-Vegetation Workshop, NASA/Goddard Space Flight Center, Greenbelt, Maryland, January 27-29, 1986, pp. 36-42.

Oechel, W.C., and J.M. Moreno. Report and recommendations of the workshop: Anticipated effects of a changing global environment on Mediterranean-type ecosystems. Valencia, Spain, September 17, 1992. (in prep.).

Oechel, W.C., and W.D. Billings. 1992. Anticipated effects of global change on carbon balance of arctic plants and ecosystems. In: T. Chapin, R. Jeffries, J. Reynolds, G. Shaver, and J. Svoboda (eds.). Arctic Physiological Processes in a Changing Climate. Academic Press. pp. 139-168.

Oechel, W.C., G. Riechers, W.T. Lawrence, T.I. Prudhomme, N. Grulke, and S.J. Hastings. 1992. CO2LT, A Closed, Null-balance System for Long-term in situ Ecosystem Manipulation and Measurement of $\mathrm{CO}_{2}$ Level, $\mathrm{CO}_{2}$ Flux, and Temperature. Functional Ecology. 6: 86-100. 
Oechel, W.C., G.H. Riechers, J. Beyers, S. Cowles, N. Grulke, S. Hastings, T.

Prudhomme, and N. Sionit. 1986. Response of vegetation to carbon dioxide: 037-Response of a tundra ecosystem to elevated atmospheric carbon dioxide. (DOE DE--AC03-82ER60079).

Oechel, W.C., S.J. Hastings, M. Jenkins, G. Riechers, N. Grulke, and G. Vourlitis. 1994. Recent Change of Arctic Tundra Ecosystems from a Carbon Sink to a Source. Nature. 361: 520-523.

Owensby, C.E., P.I. Coyne, L.M. Auen, and N. Sionit. 1990. Response of vegetation to carbondioxide: 059-Rangeland-Plant response to elevated $\mathrm{CO}_{2}$ : Large-chamber system. U.S. Department of Energy, Washington, D.C., Progress Report of Research.

Pitelka L.F. and M.T. Clegg (eds.). Ecological Genetics and Air Pollution. SpringerVerlag, New York. pp. 237-244.

Polis, G. A. 1991. Complex trophic interactions in deserts: an empirical critique of foodweb theory. Am. Nat. 138: 123-155.

Poole, D.K., and P.C. Miller. 1981. The distribution of plant water stress and vegetation characteristics in southern California chaparral. American Midland Naturalist. 105: 32-43.

Poorter, H., R.M. Gifford, P.E. Kriedemann, and S.C. Wong. 1992. A quantitative analysis of dark respiration and carbon content as factors in the growth response of plants to elevated $\mathrm{CO}_{2}$. Aust. J. Bot. 40: 501-513.

Porter, J. H., M. L. Parry, \& T. R. Carter. 1991. The potential effects of climate change on agricultural insect pests. Agric. For. Meteorol. 57: 221-240.

Rambal, S. Fire and water yield: a survey and prediction for global change. In: J.M. Moreno and W.C. Oechel (eds.). The Role of Fire in Mediterranean Ecosystems, Springer-Verlag, New York. (in review).

Rastetter, E.B., M.G. Ryan, G.R. Shaver, J.M. Melillo, K.J. Nadelhoffer, J.E. Hobbie, and J.D. Aber. 1991. A general biogeochemical model describing the responses of the $\mathrm{C}$ and $\mathrm{N}$ cycles in terrestrial ecosystems to changes in $\mathrm{CO}_{2}$, climate and $\mathrm{N}$ deposition. Tree Physiology. 9: 101-126.

Reece, C.F., S.V. Krupa, H.-J. Jager, S.W. Roberts, S.J. Hastings, and W.C. Oechel. 1995. Evaluating the effects of elevated levels of atmospheric trace gases on herbs and shrubs: A prototype dual array field exposure system. Environmental Pollution.

Reid, C. 1984. Possible physiological Indicators of senescence in two chaparral shrub species along a fire-induced age sequence. M.Sc. Thesis, San Diego State University. $159 \mathrm{pp}$.

Riggan, P.J., and P.H. Dunn. 1982. Harvesting chaparral biomass for energy-an environmental assessment. In: C.E. Conrad and W.C. Oechel. Proceeding of the Symposium on Dynamics and Management of Mediterranean-type Ecosystems, San Diego State University, San Diego, California, pp. 149-157. 
Riggan, P.J., S. Goode, P.M. Jacks, and R.N. Lockwood. 1988. Interaction of fire and community development in chaparral of southern California. Ecological Monographs. 58(3): 155-176.

Rind, D., R. Goldberg, J. Hansen, C. Rosenzweig, and R. Ruedy. 1990. Potential evapotranspiration and the likelihood of future drought. J. Geophysical Res. 95: 9983-10004.

Robbins, C.T. 1993. Wildlife Feeding and Nutrition. 2e. Academic Press, New York, NY.

Ryan, M.G. 1991. Effects of climate change on plant respiration. Ecological Applications. 1: 157-167.

Sage, R.F., Sharkey, T.D. and Seemann, J.R. 1989. Acclimation of photosynthesis to elevated $\mathrm{CO}_{2}$ in five $\mathrm{C}_{3}$ species. Plant Physiology,. 89: 590-596.

Sage, R.F., T.D. Sharkey, and J.R. Seemann. 1989. Acclimation of photosynthesis to elevated $\mathrm{CO}_{2}$ in five $\mathrm{C}_{3}$ species. Plant Physiology. 89: 590-596.

Salaski, A. 1992. Fuzzy knowledge-based models in ecological research. Ecological modeling. 63: 103-112.

Schimel, D.S. 1995. Terrestrial ecosystems and the carbon cycle. Global Change Biology. 1: 77-91.

Schimel, D.S., Braswell, B.H., Holland, E.A., McKeown, R., Ojima, D.S., Painter, T.H., Parton, W.J., and A.R. Townsend. 1994. Climatic, edaphic, and biotic controls over storage and turnover of carbon in soils. Global Biogeochemical Cycles. 8: 279-29

Schulze, W., M. Stitt, E.-D. Schulze, H.E. Neuhaus, and K. Fichtner. 1991. A quantification of the significance of assimilatory starch for growth of Arabidopsis thaliana L. Heynh. Plant Physiol. 95: 890-895.

Sellers, P. J., L. Bounoua, G. J. Collatz, D. A. Randall, D. A. Dazlich, S.Los, J. A. Berry, I. Fung, C. J. Tucker, C. B. Field, and T. G. Jenson,1996, A comparison of the radiative and physiological effects of doubledCO2 on the global climate: Science (in press).

Seemann, J.R. and Berry, J.A. 1982. Interspecific differences in the kinetic properties of RuBP carboxylase/oxygenase. Carnegie Inst. Wash. Yearbook 81: 73-83.

Seemann, J.R., Sharkey, T.D., Wang, J. and Osmond, C.B. 1987. Environmental effects on photosynthesis, nitrogen-use efficiency and metabolite pools in leaves of sun and shade plants. Plant Physiology. 84: 796-802.

Shaver, G.R., W.D. Billings, F.S. Chapin III, A.E. Giblin, K.J. Nadelhoffer, W.C. Oechel, and E.B. Rastetter. 1992. Global change and the carbon balance of arctic ecosystems. BioScience. 42: 433-441.

Southwood, T.R.E. 1978. Ecological Methods. London: Chapman and Hall.

Stitt, M. 1991a. Rising $\mathrm{CO}_{2}$ levels and their potential significance for carbon flow in photosynthetic cells. Plant Cell Env. 14: 741-762.

Stitt, M., A. von Schaewen, and L. Willmitzer. 1991b. Sink regulation of photosynthetic metabolism in transgenic tobacco plants expressing yeast invertase in their cell 
wall involves a decrease of the Calvin cycle enzymes and an increase of glycolytic enzymes. Planta. 183. 40-50.

Stitt, M., Gerhardt, R., Kurzel, B. and Heldt, H.W. 1983. A role for fructose 2,6bisphosphate in the regulation of sucrose synthesis in spinach leaves. Plant Physiol. 72: 1139-1141.

Stock, W.D., Wienand, K.T., and A.C. Baker. 1995. Impacts of invading N2-fixing Acacia species on patterns of nutrient cycling in two Cape eosystems: evidence from soil incubation studies and 15N natural abundance values. Oecologia. 101: 375-382.

Strain, B.R. 1991. Possible genetic effects of continually increasing atmospheric $\mathrm{CO}_{2}$. In: Taylor Jr., G.E.,

Strain, B.R. and F. Bazzaz. 1983. Terrestrial plant communities. In: E.R. Lemon (ed.). $\mathrm{CO}_{2}$ and Plants: The Response of Plants to Rising Levels of Atmospheric Carbon Dioxide. AAAS Selected Symposium 84. Westview Press, Inc., Boulder, Colorado. pp.

Strain, B.R. and R.B. Thomas. 1995. Anticipated effects ofelevated $\mathrm{CO}_{2}$ and climate change on plants from Mediterranean-typeecosystems utilizing results of studies in otherecosystems. In: J.M. Moreno and W.W. Oechel (eds). Anticipated Effects of a

Strain, B.R. and R.B.Thomas. 1992. Field measurements of $\mathrm{CO}_{2}$ enhancement and climate change in natural vegetation. Water, Airand Soil Pollution. 64: 45-60.

Thomas, R.B. and B.R. Strain. 1991. Root restriction as a factor in photosynthetic acclimation of cotton seedlings grown in elevated carbon dioxide. Pl. Physiol. 96: 627-634.

Tissue, D.L., and W.C. Oechel. 1987. Physiological response of Eriophorum vaginatum to field elevated $\mathrm{CO}_{2}$ and temperature in the Alaskan tussock tundra. Ecology. 68: 401-410.

Tissue, D.T., R.B. Thomas and B.R. Strain. 1993. Long-term effects of elevated $\mathrm{CO}_{2}$ and nutrients on photosynthesis and rubisco in loblolly pine seedlings. Plant, Cell and Environment. 16: 859-865.

Tissue, D.T., R.B. Thomas and B.R. Strain. 1996. Growth and photosynthesis of loblolly pine (Pinus taeda L.) after exposure to elevated $\mathrm{CO}_{2}$ for 19 months in the field. Tree Physiology. 16: 49-59.

Tolley, L.C., and B.R. Strain. 1985. Effects of $\mathrm{CO}_{2}$ enrichment and water stress on gas exchange of Liquidambar styraciflua and Pinus taeda seedlings grown under different irradiance levels. Oecologia. 65: 166-172.

Tyrrel, R.K. 1982. Chaparral in southern California. In: C.E. Conrad and W.C. Oechel. Proceedings of the Symposium on Dynamics and Management of Mediterraneantype Ecosystems, San Diego State University, San Diego, California, pp. 56-59.

Van Soest, P.J. and J.B. Robertson. 1985. Analysis of Forages and Fibrous Foods. Cornell University, New York. 
Vitousek. 1994. Beyond global warming: Ecology and global change. Ecology. 75: 1861-1876.

von Schaewen, A. M. Stitt, R. Schmidt, U. Sonnewald, and L. Willmitzer. 1991. Expression of a yeast-derived invertase in the cell wall of tobacco and Arabidopsis plants leads to accumulation of carbohydrate inhibition of photosynthesis and strongly influences growth and phenotype of transgenic tobacco plants. EMBO Journal. 9: 3033-3044.

Vourlitis, G.L., W.C. Oechel, S.J. Hastings, and M.A. Jenkins. 1993. A system for measuring in situ $\mathrm{CO}_{2}$ and $\mathrm{CH}_{4}$ flux in unmanaged ecosystems: An arctic example. Functional Ecology. 7: 369-379.

Wallach, J.D. 1970. Nutritional diseases of exotic animals. Journal of the American Veterinary Medicine Association. 157: 583-599.

Watson, R.T., H. Rodhe, H. Oeschger, and U. Siegenthaler. 1990. Greenhouse gases and aerosols. In: J.T. Houghton, G.J. Jenkins, and J.J. Ephraums (eds.). 1990. Climate Change, The IPCC Scientific Assessment. Cambridge University Press. Cambridcge, U.K. 365 pp.

Whittaker, R.H., and W.A. Niering. 1975. Vegetation of the Santa Catalina Mountains, Arizona. V. Biomass, production, and diversity along the elevation gradient. Ecology. 56: 771-790.

Wigley, T.M. and P.D. Jones. 1985. Influence of precipitation changes and direct $\mathrm{CO}_{2}$ effects on streamflow. Nature. 314: 149-152.

Wilson, S.B. 1980. Energy conservation by the plant mitochondria cyanide-insensitive oxidase. Some additional evidence. Biochemical Journal. 190: 349-360.

Woodrow, I.E. and Berry, J.A. 1988. Enzymatic regulation of photosynthetic $\mathrm{CO}_{2}$ fixation in $\mathrm{C}_{3}$ plants. Annual Review of Plant Physiology and Plant Molecular Biology. 39: 533-594.

Woodward, F.L. 1987. Stomatal numbers are sensitive to increased in $\mathrm{CO}_{2}$ from preindustrial levels. Nature. 327: 617-618.

Wulff, R.D., and B.R. Strain. 1982. Effects of $\mathrm{CO}_{2}$-enrichment on growth and photosynthesis in Desmodium paniculatum. Can. J. Bot. 60: 1084-1091.

Youngner, V.B. 1974. Effects of waste-water irrigation on chaparral. In: M. Rosenthal (ed.). Symposium on living with the chaparral. Sponsored by Sierra Club, California Dept. of Forestry, and U.S.D.A. Forest Service.

Youngner, V.B., W.D. Kesner, A.R. Berg, and L.R. Green. 1972. Progress report of the Maloney Canyon greenbelt project, University of California Water Resources Center, Contract No. 140.

Zak, D.R., Pregitzer, K.S., Teeri, J.A., Fogel, R., and D.L. Randlett. 1993. Elevated $\mathrm{CO}_{2}$ and feedback between carbon and nitrogen cycles. Plant \& Soil. 151: 10517.

Ziska, L.H., J.R. Seemann and T.M. DeJong. 1990. Salinity induced limitations on photosynthesis in Prunus salicina, a deciduous tree species. Plant Physiology. 93: $864-870$. 


\title{
Ecosystem carbon flux under elevated $\mathrm{CO}_{2}$ by $\mathrm{CO}_{2} \mathrm{LT}$ Chambers in southern
}

\section{California chaparral}

Yufu Cheng, Walter C. Oechel, Steven J. Hastings, Jonathan W. Major, Pablo J. Bryant, and Yonghai Qian

\begin{abstract}
Ecosystem carbon flux was studied using six different $\mathrm{CO}_{2}$ treatments with $\mathrm{CO}_{2}$ LT $\left(\underline{\mathrm{CO}}_{2}\right.$ controlled, Natural Lit, Temperature controlled) null balance chambers in Southern California chaparral dominated by Adenostoma faciculatum H. \& A. between 1997 and 2001. Using the chamber technique, net ecosystem flux was measured directly and continuously. Missing data were modeled using non-linear curve fitting techniques with meteorological data. The annual net ecosystem carbon flux under different $\mathrm{CO}_{2}$ treatments was accumulated from daily carbon flux values. There is a significant $\mathrm{CO}_{2}$ effect $(p=0.049)$ and year effect $(p=0.000)$ for annul NEE from 1997 to 2000 with a strong seasonal pattern of elevated $\mathrm{CO}_{2}$. Elevated $\mathrm{CO}_{2}$ delayed water stress. Although elevated $\mathrm{CO}_{2}$ enhanced leaf-level photosynthesis and decreased transpiration and conductance regardless of water availability, whole-ecosystem rates of net $\mathrm{CO}_{2}$ flux and plant water status were not significantly altered by elevated $\mathrm{CO}_{2}$ when water availability was high. Aboveground biomass (e.g. Plant Growth and leaf area index) did not show a significant effect of different $\mathrm{CO}_{2}$ treatment, while there is a significant $\mathrm{CO}_{2}$ effect on belowground bulk root biomass $(\mathrm{p}<0.015)$, which indicates the chaparral ecosystem
\end{abstract}


above ground response to the environment is very slow, which might mask, if just looking at above ground, the $\mathrm{CO}_{2}$ effect. 


\section{Introduction}

World $\mathrm{CO}_{2}$ concentration has increased about $30 \%$ over pre-industrial levels (Houghton et al., 1990, Alcamo et al. 1996). Unfortunately we do not even know with certainty the sign for net ecosystem exchange for most ecosystems (Oechel et al., 1994) now or their potential response to future $\mathrm{CO}_{2}$ concentration (Ryan 1991, Amthor 1995, Drake et al. 1999, Hymus et al. 2002). Studies at different scale across varieties of ecosystems have been reported (Strain \& Thomas 1992), including studies of the arctic tundra (e. g. Billings et al. 1984, Oechel et al. 1994, Joes et al. 1998, Press et al. 1998), Californian grasslands (Field et al. 1995, Luo et al. 1997, Cardon et al. 2001), alpine grassland (Schäppi \& Körner 1996, Diemer and Christian 1998), a prairie (Owensby et al. 1993, Hunt et al. 1998, Williams et al. 2000, Lee et al. 2001), a wetland (Drake 1992, Nungesser et al. 1999, Dakora and Drake, 2000), a crop (Yeo, 1999, Okada et al. 2001) and a desert (Huxman et al. 1998, Hamerlynck et al. 2000, Nowak et al. 2001). All these studies have given us valuable information to understand systematic dynamic carbon exchange and interaction with other biogeochemical cycles. However, a continuous and long term carbon flux monitoring across different ecosystems and regions is needed to get sufficient information for a better estimation of global carbon budget both in the present and in the future.

Plant photosynthesis is more responsive to elevated $\mathrm{CO}_{2}$ (i.e. less homeostatic adjustment to elevated $\mathrm{CO}_{2}$ ) at higher temperatures (Luo and Reynolds 1999, Hamerlynck et al., 2000), under water stress (Gifford, 1979, Tolley and Strain, 1985, 
Sgherri et al., 2000), and under adequate nutrients (Larigauderie, et al., 1988, Strain, 1992, 1995). This indicates ecosystems which are warm, drought stressed, and moderately fertile (e.g. chaparral), should be more responsive to elevated $\mathrm{CO}_{2}$ than other ecosystems. NEE and plant growth in chaparral (and related Mediterranean-type ecosystems), should therefore be fairly responsive to elevated $\mathrm{CO}_{2}$.

The responses of arid and semi-arid woody ecosystems to elevated $\mathrm{CO}_{2}$ are very important to understand because arid and semi-arid woody shrublands comprise approximately $51 \%$ of the global terrestrial surface area, $24 \%$ of the global soil organic carbon, and $16 \%$ of the global above-ground biomass (Atjay et. al., 1979). This ecosystem is likely to be especially sensitive to changes in climate, atmospheric $\mathrm{CO}_{2}$ due to the arid environment, while the data on $\mathrm{CO}_{2}$ flux from this important ecosystem is poorly known. To date, there are relative few field experiments on the effects of elevated $\mathrm{CO}_{2}$ on carbon sequestration in native woody ecosystems (Mooney et al., 1991). Understanding how these ecosystems will respond in the future to higher $\mathrm{CO}_{2}$ concentrations is very critical.

$\mathrm{CO}_{2}$ effects on carbon flux and carbon storage of unmanaged and lightly and managed ecosystem depends on complex aboveground and belowground interactions of biological and physical processes (Field et al., 1992, Jach et al. 2000, Heijmans et al. 2001). Elevated $\mathrm{CO}_{2}$ can directly affect the growth and water use of vegetation through effects on transpiration, photosynthesis, and water use efficiency (Grodzinski 1992, Palicz et al. 2000). To understand the response of the ecosystem on elevated $\mathrm{CO}_{2}$ concentration, we need to study the ecosystem under different $\mathrm{CO}_{2}$ concentration and 
monitor the environmental factors of different ecosystem concerned. This paper discusses the effect of different $\mathrm{CO}_{2}$ concentration on the net ecosystem exchange, plant water status and morphological response. By using in situ measurement, we are able to test the following hypotheses that elevated $\mathrm{CO}_{2}$ would (1) increase ecosystem carbon sequestration, (2) improve plant water status and (3) increase biomass accumulation (both aboveground and belowground).

\section{Materials and methods}

The study took place at the Sky Oaks Biological Field Station $\left(33^{\circ} 23^{\prime} \mathrm{N}\right.$, $\left.116^{\circ} 37^{\prime} \mathrm{W}\right)$, located in Southern California, at about 1,420m elevation and $75 \mathrm{~km}$ from the coast. Major shrubs present include Adenostoma sparsifolium Torr., Adenostoma faciculatum H. \& A., and Ceanothus greggii Gray. Treatments were carried out using $\mathrm{CO}_{2}$-controlled, ambient Lit, Temperature controlled null-balance chambers (Tissue and Oechel, 1987, Grulke et al., 1987, Oechel et al., 1992). The site consisted of a chaparral stand burnt in July of 1992, having previously burned back in 1898 (Marion and Black, 1988, Keeley, 1992, Zedler, 1995). Adenostoma fasciculatum is the dominant species (70\%) in California chaparral (Hanes 1977). This species regenerates after fire by seeds and by resprouting from a lignotube (Stohlgren et al. 1989, Keeley, 1992, Zedler, 1995).

Twelve closed $2 \times 2 \times 2-\mathrm{m}$ chambers are each centered around individual Adenostoma faciculatum and surrounding herbaceous plants. Atmospheric $\mathrm{CO}_{2}$ concentrations within the chambers are maintained at levels ranging from 250- to 750ppm in 100-ppm increments $(\mathrm{n}=2)$. The treatment started in December 1995. The 
chambers are naturally lit (about $93 \%$ of ambient), and temperature tracked the ambient environment (Oechel et al. 1992). Precipitation is collected from the chamber roof and induced into a bucket. A rain distribution system was set up to spray all the rainwater from above down to canopy to minimize the chamber effect.

\section{Measuring technique}

More detailed descriptions of $\mathrm{CO}_{2} \mathrm{LT}$ null balance are provided by Oechel et al (1992). The carbon flux was measured automatically by the chamber technique, which provided replicated in situ ecosystem level measurements at the 6 different $\mathrm{CO}_{2}$ concentrations. Temperatures were monitored by copper-constantan (type T) thermocouples. Carbon dioxide concentrations of each chamber was measured with an infrared gas analyzer (IRGA) (Bio 4B.2, Leybold-Heraeus, Hanau, Germany).

There are three major parts of the $\mathrm{CO}_{2}$ control and carbon flux measurements: $\mathrm{CO}_{2}$ injection, $\mathrm{CO}_{2}$ scrubs and chamber leakage. The $\mathrm{CO}_{2}$ injection was controlled by computer program, which sent command to solenoid valve and mass flow controller to determine the amount of the pure $\mathrm{CO}_{2}$ to be injected to each chamber. The mass flow controller sent the output of actual injection to computer data acquisition system accordingly. $\mathrm{CO}_{2}$ scrub is also controlled by computer program. When the chamber $\mathrm{CO}_{2}$ concentration was above the set point, the computer sent command to a solenoid valve to direct gas through a PVC tube filled with soda lime. $\mathrm{CO}_{2}$ scrub tubes of different sizes were used according to the $\mathrm{CO}_{2}$ set point. The amount of $\mathrm{CO}_{2}$ scrubbed was determined by the flow rate passing through each soda lime tube and scrubbing time. Test showed that regular soda lime check (every 3 days) is enough and critical to make sure the 
sufficiency of the soda lime. Chamber leak rate was calculated by the amount of $\mathrm{N}_{2} \mathrm{O}$ (trace gas) injection and $\mathrm{N}_{2} \mathrm{O}$ concentration measured for each chamber by the $\mathrm{N}_{2} \mathrm{O}$ IRGA. With the difference between chamber and ambient $\mathrm{CO}_{2}$ concentrations, the leakage of $\mathrm{CO}_{2}$ for each individual chamber was calculated. Net ecosystem exchange was calculated by $\mathrm{CO}_{2}$ injection, $\mathrm{CO}_{2}$ scrub, $\mathrm{CO}_{2}$ leakage and the variation of the $\mathrm{CO}_{2}$ concentration within each chamber for every three minutes.

\section{Data analysis}

The data acquisition system recorded all the raw data automatically at 3-minute basis for all the chambers, and then we reduced all the raw data to hourly basis, missing data are modeled by curve fitting method with meteorological data. " $\mathrm{CO}_{2}$ Exchange"(Viktor, 1995, Vourlitis et al., 2000) program was used to estimate the missing data and to model the GPP, Ecosystem Respiration. The " $\mathrm{CO}_{2}$ Exchange" program was designed to provide a full set of daily and seasonal estimations for the $\mathrm{CO}_{2}$ exchange between plant's ecosystem and the atmosphere. The program uses statistical analysis based on the in situ flux measurement to estimate the carbon flux (gross primary productivity, net ecosystem exchange and ecosystem respiration). For each day's measurement, the program use the hourly summed measured flux data and the weather data either from chambers data acquisition system or the weather station to make the daily estimation. The weather data will mainly include the solar radiation (in PAR) and the chamber temperature (equal to air temperature in this study).

Ecosystem respiration (ER) was modeled as an exponential function of temperature (Billings et al. 1977, Bunnell et al., 1977 Oechel et al., 1995, Vourlitis et al. 2000) 


$$
E R=a \exp (b T)
$$

Where $\mathrm{a}$ is the base estimation of the ER at the temperature $0 \mathrm{C}, \mathrm{b}$ is the ER sensitivity to the temperature and $\mathrm{T}$ is the chamber (ambient in the study) temperature.

Hourly gross primary production (GPP) was described as a hyperbolic function of photosynthetic active radiation (PAR):

$$
G P P=\frac{a Q b}{a Q+b}
$$

Where $\mathrm{a}$ is the estimation estimated quantum yield; $\mathrm{Q}$ is PAR, and $\mathrm{b}$ is the photosynthesis capacity of the PAR. All of the parameters were estimated by nonlinear regression. Net ecosystem exchange (NEE) is the difference of the GPP and ER.

\section{Plant morphology measurement}

Plant stem growth was measured in each chambers and chamber controls during the study period. In general there was very little plant growth between August to March, so that growth data reported here are generally accumulated from March to July. Six stems of Adenostoma faciculatum were randomly selected before plant growth in each year. The length of the selected stems was measured from the basal connection to the other stems. Shoot growth was intensively measured (every other weeks) during the growing season. Leaf area index (LAI) was calculated by the volume of plant canopy (length*width*height) and an empirical equation (Ref.).

\section{Plant stem water potential measurement}

Predawn stem water potentials were measured each month or every other month for each chamber and in the FACE and their controls by using a pressure bomb 
(Scholander et al. 1965). Two samples were collected from each chamber and outside chambers as control. Six samples were collected in the FACE (treated at 550 ppmv $\mathrm{CO}_{2}$ ) and FACE control for the comparison of the chamber plants and chamberless plants for the same $\mathrm{CO}_{2}$ concentration treatment to test the chamber effect regarding water stress. Samples are general takes between 3 and 4 in the morning for the stable water potential measurement. Samples from each treatment were measured immediately after the cutting.

\section{Statistics}

Relationships between annual $\mathrm{NEE}$ and $\mathrm{CO}_{2}$ concentration and accumulative effect (year in this case) were tested though linear regression analyses using Systat9.0 (SPSS 1999) and SigmaPlot 2000 (SPSS 2000). Analysis of variance (ANOVA) was performed to test the effect of different $\mathrm{CO}_{2}$ treatments on plant shoot and leaf area index. Pair wise comparisons were conducted using a Kolmogorov-Smirnov test. Plant water potentials were analyzed using T-test for a difference between the elevated $\mathrm{CO}_{2}$ treatment (550 ppm) and ambient treatment (365ppm) as well as between seasons. In all cases, results were considered significant when $\mathrm{P}<0.05$.

\section{Results}

\section{Carbon flux (net ecosystem exchange)}

Mean average daily net ecosystem exchange in wet and dry season showed different pattern (fig. 1). The mean of the night time ecosystem respiration (as seen from night time NEE) was ranged from 0.051 to $0.134 \mathrm{gC} / \mathrm{m}^{2} / \mathrm{h}$ in January and from 0.113 to $0.247 \mathrm{gC} / \mathrm{m}^{2} / \mathrm{h}$ in June for all four years, which was $184 \%$ to $222 \%$ percent enhancement 
of the nighttime ecosystem respiration. which shows higher temperature enhanced ecosystem respiration. Daytime NEE in June was a stronger sink or smaller source in June than those in January especially for very high $\mathrm{CO}_{2}$ growth concentrations (e.g. 650 ppm and $750 \mathrm{ppm}$ ). The mean maximum of NEE (highest sink) in the day for January ranged from $-0.176 \mathrm{gC} / \mathrm{m}^{2} / \mathrm{h}$ to $-0.379 \mathrm{gC} / \mathrm{m}^{2} / \mathrm{h}$ for January and from $-0.216 \mathrm{gC} / \mathrm{m}^{2} / \mathrm{h}$ to $-0.628 \mathrm{gC} / \mathrm{m}^{2} / \mathrm{h}$ for June, which shows $122 \%$ to $165 \%$ increment of daily NEE. For both January and June, higher $\mathrm{CO}_{2}$ treatment enhanced ecosystem carbon sink strength (fig. 1), the daily maximum NEE difference between lowest treatment and highest treatment for the January was $0.127 \mathrm{gC} / \mathrm{m}^{2} / \mathrm{h}$, while for the June was $0.267 \mathrm{gC} / \mathrm{m}^{2} / \mathrm{h}$, which was $210 \%$ percent increment. This indicates that the effects of elevated $\mathrm{CO} 2$ was stronger during growing season (e.g. June) verse now-growing season (e.g. January).

Annual net ecosystem exchange $\mathrm{CO}_{2}$ fertilizer effect in the 1997 to 2000 (fig. 2) indicated that there were significant $\mathrm{CO}_{2}$ treat effect $(\mathrm{p}=0.049)$ and precipitation/year effect $(\mathrm{p}=0.000)$ (table 1$)$, while there is no significant effect of the interaction of $\mathrm{CO}_{2}$ and year effect on the annul NEE. The strongest CO2 fertilizer effect is in 1999, for the highest $\mathrm{CO} 2$ treatment (750 ppm), the $\mathrm{CO} 2$ fertilizer effect was $1104 \mathrm{gC} / \mathrm{m}^{2} / \mathrm{h}$, which is more than 3 times more than that in 1998. Annual gross primary productivity (GPP) in 1997 to 2000 (fig. 3) also showed that there is a significant $\mathrm{CO}_{2}$ effect ( $\left.\mathrm{p}=0.000\right)$ and year effect $(\mathrm{P}=0.003)$, while no $\mathrm{CO}_{2}$ and year interaction effect $(\mathrm{p}=0.928)$. The $\mathrm{CO}_{2}$ effect (as deduced from the slope of the regression line) on annul carbon flux were significant different on the four year basis, which shows during the driest year (1999, with the 
precipitation $247 \mathrm{~mm}$ fig. 4 ), the $\mathrm{CO}_{2}$ effect is the highest (as the slope is steepest), and it is the lowest for the wettest year. (1998, with the precipitation 725mm, fig. 4) (fig. 3).

The gross primary productivity (GPP) shows there was a tend for the increment for the both with $\mathrm{CO}_{2}$ concentration increment and year increment (fig. 3) although there were some exception like GPP in 1999 for most treatment showed less than 1998 (wettest year) and GPP under 550 ppm $\mathrm{CO}_{2}$ in 1999 (driest year) was significant lower than 450 ppm treatment. These were also due to the reason stated above.

Seasonal pattern of the elevated $\mathrm{CO}_{2}(550 \mathrm{ppm})$ effect on plant water relation can also be seen in the predawn water potentials (fig. 4). The seasons were divided into two for statistically analysis: dry (monthly precipitation less than median) and wet (monthly precipitation greater than median). There is a significant season effect (comparing dry season and wet season) on the water potential $(\mathrm{p}=0000)$, no significant $\mathrm{CO}_{2}$ treat effect in both dry season $(\mathrm{p}=0.074)$ and wet season $(\mathrm{p}=0.055)$. However, if just comparing the two different treatments by chambers, there was significant difference in the dry seasons $(\mathrm{p}=0.027)$ although there was no significant difference in wet season $(\mathrm{p}=0.308)$. There was significant difference between plant water potential in FACE (treated by $550 \mathrm{ppm}$ $\mathrm{CO}_{2}$ ) FACE control (ambient 365ppm) in the dry season $(\mathrm{p}=0.017)$ and no significant difference in wet season $(\mathrm{p}=0.423)$. There is significant difference for the chamber treatment and chamberless treatment at both $550 \mathrm{ppm}(\mathrm{p}=0.037)$ and $350 \mathrm{ppm}$ treatment $(\mathrm{p}=0.041)$ in the dry season only. This indicated that both elevated $\mathrm{CO}_{2}$ and chamber can delay water stress. 


\section{Plant morphological response}

There is no significant $\mathrm{CO}_{2}$ effect on plant growth and LAI although there is a trend they are higher in higher $\mathrm{CO}_{2}$ growth concentration (Table 2). The low number of replicates $(n=2)$ reduced the statistical power, and the chaparral ecosystem above ground response to the environment is very slow (Black, 1987), which might mask the $\mathrm{CO}_{2}$ effect temporally. Belowground studies at the same site showed there is significant $\mathrm{CO}_{2}$ enhancement for the root biomass especially for upper layers (Treseder et al. personal communication).

\section{Discussion}

In global change researches, it is still an elusive goal to generalize the responses of different plant species to elevated atmospheric $\mathrm{CO}_{2}$ concentrations. However, different ecosystem or species might respond differently because of the unique character and environmental factors (Pearcy \& Ehleringer, 1984; Curtis et al., 1989). From this study, we knew that the average annual NEE of all treatments showed $136.5 \mathrm{gC} / \mathrm{m}^{2} / \mathrm{h}, 58.4$ $\mathrm{gC} / \mathrm{m}^{2} / \mathrm{h}, 338.8 \mathrm{gC} / \mathrm{m}^{2} / \mathrm{h},-45.4 \mathrm{gC} / \mathrm{m}^{2} / \mathrm{h}$ for $1997,1998,1999$ and 2000 respectively, which was the tend to increase sink strength to the atmospheric $\mathrm{CO}_{2}$ when the plants were getting older and bigger, except for 1999, which is the driest year for the record. The average of the NEE of the four years for different $\mathrm{CO}_{2} 444.8 \mathrm{gC} / \mathrm{m}^{2} / \mathrm{h}, 357.3 \mathrm{gC} / \mathrm{m}^{2} / \mathrm{h}$, $234.3 \mathrm{gC} / \mathrm{m}^{2} / \mathrm{h}, 302.6 \mathrm{gC} / \mathrm{m}^{2} / \mathrm{h},-65.4 \mathrm{gC} / \mathrm{m}^{2} / \mathrm{h},-68.8 \mathrm{gC} / \mathrm{m}^{2} / \mathrm{h}$ for the six different $\mathrm{CO}_{2}$ concentration treatments (from $250 \mathrm{ppm}$ to $750 \mathrm{ppm}$ ). There is a tend for the $\mathrm{CO}_{2}$ enhancement as the $\mathrm{CO}_{2}$ concentration increases except for $550 \mathrm{ppm}$ treatment, which 
was highly due to the air conditioning system failure in 1999 almost killed the plants inside one of $550 \mathrm{ppm} \mathrm{CO}_{2}$ treated chambers which made the average NEE in 1999 was a strong source to the atmosphere.

The results reported here indicate that chaparral ecosystems are likely to increase carbon sequestration under potential future elevated $\mathrm{CO}_{2}$, which increased water use efficiency that might avoid the water stress of the plant and the entire ecosystem (Strain \& Thomas 1995). Both daily NEE and annul NEE response to elevated $\mathrm{CO}_{2}$ shows strong seasonal pattern, which is, during the wet seasons, there is no significant difference for the NEE response to elevated $\mathrm{CO}_{2}$, while during dry seasons there is a significant difference for the elevated $\mathrm{CO}_{2}$ and ambient $\mathrm{CO}_{2}$ treat. This is consistent to leaf level scaled carbon flux measurement. Net photosynthetic measurements at the growth $\mathrm{CO}_{2}$ concentration $\left(\mathrm{A}_{\text {growth }}\right)$, show significant effects of the $\mathrm{CO}_{2}$ treatments on net photosynthetic rates (Ibanez et al. 2001). Elevated $\mathrm{CO}_{2}$ enhancing effects varied by season and year, with the greatest $\mathrm{CO}_{2}$ effect during the dry and growing seasons.

Photosynthesis rate was consistently enhanced on average by $66 \%$ by reviewing of experiments with trees treated by plus $300 \mu_{\mathrm{mol} \mathrm{mol}}^{-1}$ elevated $\mathrm{CO}_{2}$ (Norby et al., 1999). A primary response of $\mathrm{C}_{3}$ plants to elevated atmospheric $\mathrm{CO}_{2}$ concentrations is believed to increase in the net assimilation rate and an associated decrease in the transpiration rate at leaf scale (Morrison, 1987; Kimball et al., 1995). Intrinsic differences in photosynthetic biochemistry structure should lead to markedly different responsiveness to elevated $\mathrm{CO}_{2}$ which is supported by theory and early field studies ( Pearcy \& Ehleringer, 1984; Curtis et al., 1989). 
The results reported here also show that the elevated $\mathrm{CO}_{2}$ enhancing NEE (fig. 1 and fig. 2) cannot be detected by aboveground morphological responses (table 2), while there is a significant $\mathrm{CO}_{2}$ effect on root biomass Several studies have suggested that more carbon is fixed due to a larger increase in leaf-level or canopy-level NEE in systems exposed to elevated $\mathrm{CO}_{2}$ than could be subsequently found in plant biomass and soils (Norby, et al. 1992, Körner et al. 1996, Treseder et al. 2001). Interestingly, there is an significant carbon sink for one of $650 \mathrm{ppm}$ treatment, but no new growth was detected in that year. The results agree with findings for the Eurasian Avena barbata in Californian grassland (Jackson et al. 1995) and for A. barbata, Aegilops cylindrica and Aegilops neglecta in southern France ( Navas et al. 1995, 1997). There is no significant difference regarding biomass production of these species treated by $700 \mathrm{ppm} \mathrm{CO}_{2}$ compared to current ambient $\mathrm{CO}_{2}$ concentration. To detect all the carbon flux and carbon allocation through the whole ecosystem, we need to make the simultaneous, accurate measurement of the systematic carbon dynamics (input and output). However, considering the chaparral situation, rocky soil and deep roots, it will await more effort in studying belowground carbon dynamics.

In water-limited ecosystems, the effects of elevated $\mathrm{CO}_{2}$ on Carbon balance often involve interactions with water (Owensby et al. 1999). Combined with the FACE water potential results, it is clearly that there is significant difference for the ambient $\mathrm{CO} 2$ treatment and elevated $\mathrm{CO}_{2}$ treatment in the dry season by analyzing the chamber treatment or chamberless treatment separately. There is no significant difference in the wet season. The results also showed that there is a strong chamber effects on plant stem 
predawn water potential, especially in dry season. Plants in a close chambers environments may have less water loss since the relative humidity in the chambers was substantially higher than outside environment.

In conclusion, for A. faciculatum growing in the nature field, the effect of elevated $\mathrm{CO}_{2}$ on net ecosystem exchange is generally increasing carbon uptake with the increase of the $\mathrm{CO}_{2}$ although there were some exception. There is a strong seasonal pattern of this effect that is during relative dry season or dry year, the $\mathrm{CO}_{2}$ effect is bigger than the relative wet scenario. There is no significant difference for the plant morphological response detected. There was a big variation for the different $\mathrm{CO}_{2}$ effect, to get more confident on what the effects of $\mathrm{CO} 2$ on the complicated ecosytem, a longer in situ experiments are strongly suggested. 


\section{Literature cited}

Alcamo J., Kreileman G. J. J., Bollen J. C., Born G. J. van den, Gerlagh R., Krol M. S., Toet A. M. C. and Vries H. J. M. de 1996. Baseline scenarios of global environmental change, In Global Environmental Change 6(4): 261-303.

AmthorJS (1995) Terrestrial higher-plant responses to increasing atmospheric $\left[\mathrm{CO}_{2}\right]$ in relation to the global carbon cycle. Global Change Biology, 1, 243-274.

Atjay, G.L., Ketner, P., and Duvigneaud, P. 1979. Terrestrial primary production and phytomass. Pages 129-182, In: B. Bolin, E. Degens, S. Kempe, and P. Ketner (eds.). The Global Carbon Cycle, SCOPE 13. Wiley, Chichester.

Cain, J. D., Rosier, P. T. W., Meijninger, W., De Bruin, H. A. R.. Spatially averaged sensible heat fluxes measured over barley. In: Agricultural and Forest Meteorology 19 April, 2001. 107 (4): 307-322.

Cardon, Z. G., Hungate, B. A., Cambardella, C. A., Chapin, F. S.,, Field, C. B., Holland, E. A., Mooney, H. A.. 2001. Contrasting effects of elevated CO2 on old and new soil carbon pools. Soil Biology \& Biochemistry 33 (3): 365-373.

Carlson, R.W. and Bazzaz, F.A. 1980. The effects of elevated $\mathrm{CO}_{2}$ concentrations on growth, photosynthesis, transpiration, and water use efficiency of plants. In: Singh, J.J. and Deepak, A. (eds) Environmental and climatic impact of coal utilization. Academic Press, pp 609-623.

Curtis PS, Drake BG, Leadley PW, Arp WJ, Whigham DF. 1989. Growth and senescence in plant communities exposed to elevated $\mathrm{CO}_{2}$ concentrations on an estuarine marsh . Oecologia 78: 2026.

Dakora, F. D., Drake, B. G.. 2000. Elevated CO2 stimulates associative N2 fixation in a C3 plant of the Chesapeake Bay wetland. Plant Cell and Environment, 23 (9): 943-953.

De Angelis, P., Scarascia-Mugnozza, G. E.. 1998. Long-term CO2 enrichment in a Mediterranean natural forest: An application of large open top chambers. Chemosphere 36 (4-5): 763-770.

Diemer, Matthias, Koerner, Christian. 1998. Transient enhancement of carbon uptake in an alpine grassland ecosystem under elevated CO2. Arctic and Alpine Research 30 (4): 381-387.

Drake, BG 1992 A field study of the effect of elevated $\mathrm{CO}_{2}$ on ecosystem processes in a Chesapeake Bay wetland. Australian Journal of Botany, 40, 579-595.

DrakeBG, Azcon-BietoJ, BerryJ, BunceJ, DijkstraP, FarrarJ, GiffordRM, GonzalezMelerMA, KochG, LambersH, SiedowJ, WullschlegerS (1999) Does elevated atmospheric $\mathrm{CO}_{2}$ concentration inhibit mitochondrial respiration in green plants. Plant, Cell and Environment, 22, 649-657.

Field, C. B., F. S. Chapin, P. A. Matoson, and H. A. Mooney. 1992. Response of terrestrial ecosystems to the changing atmosphere: A resource-based approach. Ann. Rev. Ecol. Syst. 23: 201-235. 
Field, CB, Jackson, RB \& Mooney, HA 1995 Stomatal responses to increased $\mathrm{CO}_{2}$ : Implications from the plant to the global scale. Plant, Cell, and Environment, 18, 1214-1225.

Gifford, R.M. 1979. Growth and yield of $\mathrm{CO}_{2}$-enriched wheat under water-limited conditions. Aust. J. Plant Physiol., 6, 367-369.

Grodzinski, B. 1992. Plant nutrition and growth regulation by $\mathrm{CO}_{2}$ enrichment. The effects of high $\mathrm{CO}_{2}$ on a plant are the consequence of many direct and indirect processes. BioScience/ 42: 517-525.

Hamerlynck EP, Huxman TE, Loik ME, Smith SD (2000). Effects of extreme high temperature, drought and elevated $\mathrm{CO}_{2}$ on photosynthesis of the Mojave Desert evergreen shrub, Larrea tridentata. Plant Ecology 148 (2): 185-195

Hamerlynck, E. P., Huxman, T. E., Nowak, R. S., Redar, S., Loik, M. E., Jordan, D. N., Zitzer, S. F., Coleman, J. S., Seemann, J. R., Smith, S. D.. 2000. Photosynthetic responses of Larrea tridentata to a step-increase in atmospheric $\mathrm{CO} 2$ at the Nevada Desert FACE Facility. Journal of Arid Environments 44 (4): 425-436.

Heijmans, Monique M. P. D., Berendse, Frank, Arp, Wim J., Masselink, Ab K., Klees, Herman, De Visser, Willem, Van Breemen, Nico. 2001. Effects of elevated carbon dioxide and increased nitrogen deposition on bog vegetation in the Netherlands. Journal of Ecology 89 (2): 268-279.

Houghton, JT, Jenkins, GJ \& Ephraums, JJ 1990. Climate Change: the IPCC Scientific Assessment. Cambridge University Press. Cambridge.

Houghton, R.A., J. E. Hobbie, J. M. Melillo, B. Moorw et al. 1983. Change in the carbon content of terrestrial bita and soil between 1860 and 1980: A net release of $\mathrm{CO}_{2}$ to the atmosphere. Ecol. Mongr. 53: 235-262.

Hunt, H. W., Morgan, J. A., Read, J. J.. 1998. Simulating growth and root-shoot partitioning in prairie grasses under elevated atmospheric $\mathrm{CO} 2$ and water stress. Annals of Botany (London), 81 (4): 489-501.

Huxman, Travis E., Hamerlynck, Erik P., Jordan, Dean N., Salsman, Katrina J., Smith, Stanley D.. 1998. The effects of parental CO2 environment on seed quality and subsequent seedling performance in Bromus rubens. Oecologia (Berlin), 114 (2): 202-208.

Hymus, Graham J., Snead, Tom G., Johnson, David P., Hungate, Bruce A. \& Drake, Bert G. Acclimation of photosynthesis and respiration to elevated atmospheric $\mathrm{CO}_{2}$ in two Scrub Oaks.Global Change Biology 8 (4), 317-328.

Ibanez Ines, Walter C. Oechel, Steven J. Hastings, and David Tissue 2000. Patterns of and controls on photosynthetic acclimation to long term exposure to elevated $\mathrm{CO} 2$ in a semi-arid Mediterranean-type shrubland ecosystem. In manuscript.

Jach, M. E., Laureysens, I., Ceulemans, R.. 2000. Above- and below-ground production of young Scots pine (Pinus sylvestris L.) trees after three years of growth in the field under elevated CO2. Annals of Botany (London) 85 (6): 789-798.

Jackson, RB, Luo, Y, Cardon, ZG, Sala, OE, Field, CB, Mooney, HA 1995

Photosynthesis, growth and density for the dominant species in a $\mathrm{CO}_{2}$-enriched grassland . Journal of Biogeography, 22, 221225. 
Jekins, M. A., 1993. Effect of atmospheric $\mathrm{CO}_{2}$ leveel and water stress on growth and physiology of two species of chaparral shrubs. MSc. Thesis. San Diego State University.

Jones, H. G. (1992). "Plant and Microclimate," $2^{\text {nd }}$ edition. Cambridge University Press, Cambridge.

Jones, M. H., Fahnestock, J. T., Walker, D. A., Walker, M. D., Welker, J. M.. 1998 Carbon dioxide fluxes in moist and dry Arctic tundra during the snow-free season: Responses to increases in summer temperature and winter snow accumulation. In: Arctic and Alpine Research 30 (4): 373-380.

Keeley, J E. Demographic structure of California chaparral in the long-term absence of fire. Journal of Vegetation Science, v.3, n.1, 1992:79-90

Kimball, B.A. and Idson, S.B. 1983. Increasing atmospheric $\mathrm{CO}_{2}$ : effects on crop yield, water use and climate. Agricultural Water Management, 7, 55-72.

Kimball, B.A., Pinter Jr., P.J., Garcia, R.L., LaMorte, R.L., Wall, G.W., Hunsaker, D.J., Wechsung, G., Wechsung, F. and Kartschall, Th., 1995. Productivity and water use of wheat under free-air $\mathrm{CO}_{2}$ enrichment. Global Change Biol. 1, pp. 429-442

Kummerow, J.. 1981. Structure of roots and root systems. In: F. Di Castri, D. W. Goodall, and R. L. Specht (eds.). Ecosystems of the world Vol. 11. Mediterranean-type shrublands. Elsevier Scientific Publishing Company, Amsterdam, pp. 1-52.

Lee TD, Tjoelker MG, Ellsworth DS, Reich PB. 2001. Leaf gas exchange responses of 13 prairie grassland species in the field under elevated carbon dioxide and increased nitrogen supply. New Phytologist 150: 000-000.

Lee, Tali D., Tjoelker, Mark G., Ellsworth, David S., Reich, Peter B.. 2001. Leaf gas exchange responses of 13 prairie grassland species to elevated $\mathrm{CO} 2$ and increased nitrogen supply. New Phytologist May, 150 (2): 405-418.

Luo Y. and Reynolds J.F.,1999. Validity of extrapolating field $\mathrm{CO}_{2}$ experiments to predict carbon sequestration in natrual ecosystems. Ecology 80 (5) 1568-1583.

Luo, Y., Chen, J.-L., Reynolds, J. F., Field, C. B., Mooney, H. A.. 1997. Disproportional increases in photosynthesis and plant biomass in a Californian grassland exposed to elevated CO2: A simulation analysis. Functional Ecology 11 (6): 696-704.

Marion, G M; Black, C H. Potentially available nitrogen and phosphorus along a chaparral fire cycle chronosequence. Soil Science Society of America Journal, v.52, n.4, 1988:1155-1162

Mayr, Christiane, Miller, Morten, Insam, Heribert. 1999. Elevated CO2 alters community-level physiological profiles and enzyme activities in alpine grassland. Journal of Microbiological Methods 36 (1-2): 35-43.

Mooney, H. A., Drake, B. G., Luxmoore, R. J., Oechel, W. C. and Pitelka, L. F. 1991. Predicting ecosystem responses to elevated $\mathrm{CO}_{2}$ concentrations, Bioscience $\mathbf{4 1}$, 96-104.

Morrison, J.I.L., 1987. Intercellular $\mathrm{CO}_{2}$ concentration and stomatal response to $\mathrm{CO}_{2}$, In: Zeiger, E., Farquhar, G.D., Cowan, I.R., (Eds.), Stomatal Function, Stanford University Press, Stanford, CA, pp. 229-251 
Navas, M-L, Guillerm, J-L, Fabreguettes, J, Roy, J 1995 The influence of elevated $\mathrm{CO}_{2}$ on community structure, biomass and carbon balance of Mediterranean old-field microcosms . Global Change Biology, 1, 325335.

Navas, M-L, Sonie, L, Richarte, J, Roy, J 1997 The influence of elevated $\mathrm{CO}_{2}$ on species phenology, growth and reproduction in a Mediterranean old-field community . Global Change Biology, 3, 523530.

Norby RJ, Wullschleger SD, Gunderson CA, Johnson DW and Ceulemans R. , 1999. Tree responses to rising $\mathrm{CO}_{2}$ in field experiments: implications for the future forest. Plant, Cell and Environment 22, pp. 683-714.

Nowak, Robert S., DeFalco, Lesley A., Wilcox, Carolyn S., Jordan, Dean N., Coleman, James S., Seemann, Jeffrey R., Smith, Stanley D.. Leaf conductance decreased under free-air $\mathrm{CO} 2$ enrichment (FACE) for three perennials in the Nevada desert. New Phytologist May, 2001.

Nungesser, Martha K., Joyce, Linda A., McGuire, A. David. 1999. Effects of spatial aggregation on predictions of forest climate change response. Climate Research 11 (2): 109-124.

Oechel, W. C., Hastings, S. J., Vourlitis G, Jenkins M, Riechers G, Grulke N, 1993. Recent change of Arctic tundra ecosystems from a net carbon dioxide sink to a source. Nature, 361, 520-523.

Oechel, W. C., Riechers, 1992. ' $\mathrm{CO}_{2} \mathrm{LT}$ ' an automated, null-balance system for studying the effected $\mathrm{CO}_{2}$ and global climate change on unmanaged ecosystems. Functional Ecology 1992 6, 86-100.

Oechel, W.C., Cowles, S., Grulke, N., Hastings, S.J., Lawrence, B., Prudhomme, T., Riechers, G., Strain, B., Tissue, D. \& Vourlitis, G. (1994) Transient nature of $\mathrm{CO}_{2}$ fertilization in arctic tundra. Nature 371, 500-503.

Okada, M., Lieffering, M., Nakamura, H., Yoshimoto, M., Kim, H. Y., Kobayashi, K.. 2001. Free-air CO2 enrichment (FACE) using pure CO2 injection: System description. New Phytologist May, 150 (2): 251-260.

Owensby CE, Coyne PI, Ham JM, Auen LM, Knapp AK. 1993. Biomass production in a tallgrass prairie ecosystem exposed to ambient and elevated $\mathrm{CO}_{2}$. Ecological Applications 3: 644653.

Owensby, CE, Coyne, PI, Ham, JM, Auen, LM \& Knapp, AK 1993 Biomass production in a tallgrass prairie ecosystem exposed to ambient and elevated $\mathrm{CO}_{2}$. Ecological Applications, 3, 644-653.

Palicz, G., Tuba, Z., Kobor, Sz. 2000 (12th Congress of the Federation of European Societies of Plant Physiology Budapest, Hungary August 21-25, 2000). Production ecological responses of seven weed species under elevated $\mathrm{CO} 2$ concentration. In: Plant Physiology and Biochemistry (Paris) 38 (Supplement): s263.

Pearcy RW \& Ehleringer J. 1984. Comparative ecophysiology of $\mathrm{C}_{3}$ and $\mathrm{C}_{4}$ plants . Plant, Cell \& Environment 7: 113. 
Press, Malcolm C., Callaghan, Terry V., Lee, John A.. 1998. How will European arctic ecosystems respond to projected global environmental change? Ambio 27 (4): 306-311.

Rey, A. and Jarvis, P.G. 1998. Long-term photosynthetic acclimation to increased atmospheric $\mathrm{CO}_{2}$ concentration in young birch (Betula pendula) trees. Tree Physiol., 18, 441-450.

RyanMG (1991) Effects of climate change on plant respiration. Ecological Applications, 1, 157-167.

Schäppi, R \& Körner, Ch 1996 Growth responses of an alpine grassland to elevated $\mathrm{CO}_{2}$. Oecologia, 105, 43-52.

Sgherri, C.L., Salvateci, P., Menconi, M., Raschi, A., and Navari-Izzo, F. 2000. Interaction between drought and elevated $\mathrm{CO}_{2}$ in the response of alfalfa plants to oxidative stress. J. Plant Physiol., 156(3), 360-366.

Smith SD, Huxman TE, Zitzer SF, Charlet TN, Housman DC, Coleman JS, Fenstermaker LK, Seemann JR, Nowak RS (2000) Elevated $\mathrm{CO}_{2}$ increases productivity and invasive species sucess in an arid ecosystem. Nature 408:79-82

Smith SD, Jordan DN, Hamerlynck EP (1999) Effects of elevated $\mathrm{CO}_{2}$ and temperature stress on ecosystem processes. Pages 107-137 in Luo Y, Mooney HA (eds) Carbon Dioxide and Environmental Stress. Academic Press, San Diego SPSS (1999) Systat 9.0 Chicago.

SPSS (2000) Sigmaplot 2000. Version 6.10. Chicago

Stohlgren TJ, Rundel PW, Parsons DJ, 1989. Statble population size class distribution in mature chamise chaparral. In: Keeley SC (ed) The California chaparral -paradigms reexamined(Science Series No 34). Natural History Museum of Los Angeles

Strain, B.R. and Thomas, R.B. 1995. Anticipated effects of elevated $\mathrm{CO}_{2}$ and climatic change on plants from Mediterranean-type ecosystems utilizing results of studies in other ecosystems. In Moreno, J.M., and Oechel, W.C. (eds), Anticipating effects of a changing global environment on Mediterranean-type ecosystems. Springer Verlag Publishers, New York.

Strain, BR \& Thomas, RB 1992 Field measurements of $\mathrm{CO}_{2}$ enhancement and change in natural vegetation. Water, Air and Soil Pollution, 64, 45-60.

Tissue, D. T., and Oechel, W. C.. 1987. Physiological response of Eriophorum vaginatum to field elevated $\mathrm{CO}_{2}$ and temperature in Alaska tussock tundra. Ecology. 68: 401-410.

Tolley, L.C. and Strain, B.R. 1984. Effects of atmospheric $\mathrm{CO}_{2}$ enrichment and water stress on growth of liquidambar styraciflua and Pinus tadea seedlings. Can. J. Bot., 62, 2135-2139.

Treseder KK, Cheng Y, Allen MF, Oechel, WC. ${ }^{13} \mathrm{C}$ tracers of carbon allocation to roots under a $\mathrm{CO}_{2}$ gradient in intact southern Californian chaparral, summitted.

Volaire, F., Lelievre, F.. Drought survival in Dactylis glomerata and Festuca arundinacea under similar rooting conditions in tubes. In: Plant and Soil February, 2001. 229 (2): $225-234$. 
Vourlitis GL, Oechel WC, Hope A, Stow D, Boynton B, Verfaillie J Jr., Zulueta R, and Hastings S. 2000. Physiological models for scaling plot-measurements of CO2 flux across an arctic tundra landscape. Ecological Applications 10:60-72.

Wand SJ, Midgley GF, Jones MH, Curtis PS. 1999. Responses of wild $\mathrm{C}_{4}$ and $\mathrm{C}_{3}$ (Poaceae) species to elevated atmospheric $\mathrm{CO}_{2}$ concentration: a meta-analytic test of current theories and perceptions . Global Change Biology 5: 723741.

Williams, Mark A., Rice, Charles W., Owensby, Clenton E.. 2000. Carbon dynamics and microbial activity in tallgrass prairie exposed to elevated $\mathrm{CO} 2$ for 8 years. Plant and Soil 227 (1-2): 127-137.

Yeo, Anthony. Predicting the interaction between the effects of salinity and climate change on crop plants. In: Scientia Horticulturae (Amsterdam) Jan. 1, 1999. 78 (1-4): 159-174.

Yoder C , Vivin P, DeFalco LA, Seemann JR, Nowak RS (2000) Root growth and function of three Mojave Desert grasses in response to elevated atmospheric $\mathrm{CO}_{2}$ concentration. New Phytologist 145: 245-256

Zedler, P. H. 1995. Fire frequency in southern California shrublands: biological effects and management options. Pp. 101-112 in J. E. Keeley and T. Scott (eds.). Brushfires in California Wildlands: Ecology and Resource Management. International Association of Wildland Fire, Fairfield, Washington. 
Figure 1. Mean $( \pm \mathrm{SE})$ average daily net ecosystem exchange (NEE) $\left(\mathrm{gC} / \mathrm{m}^{2} / \mathrm{h}\right)$ for chaparral ecosystem (dominated by Adenostoma fasciculatum with the age 5-8 years) in Sky Oaks of Southern California in January (wet and non growing season) and June (dry and growing season) between 1997 and 2000.

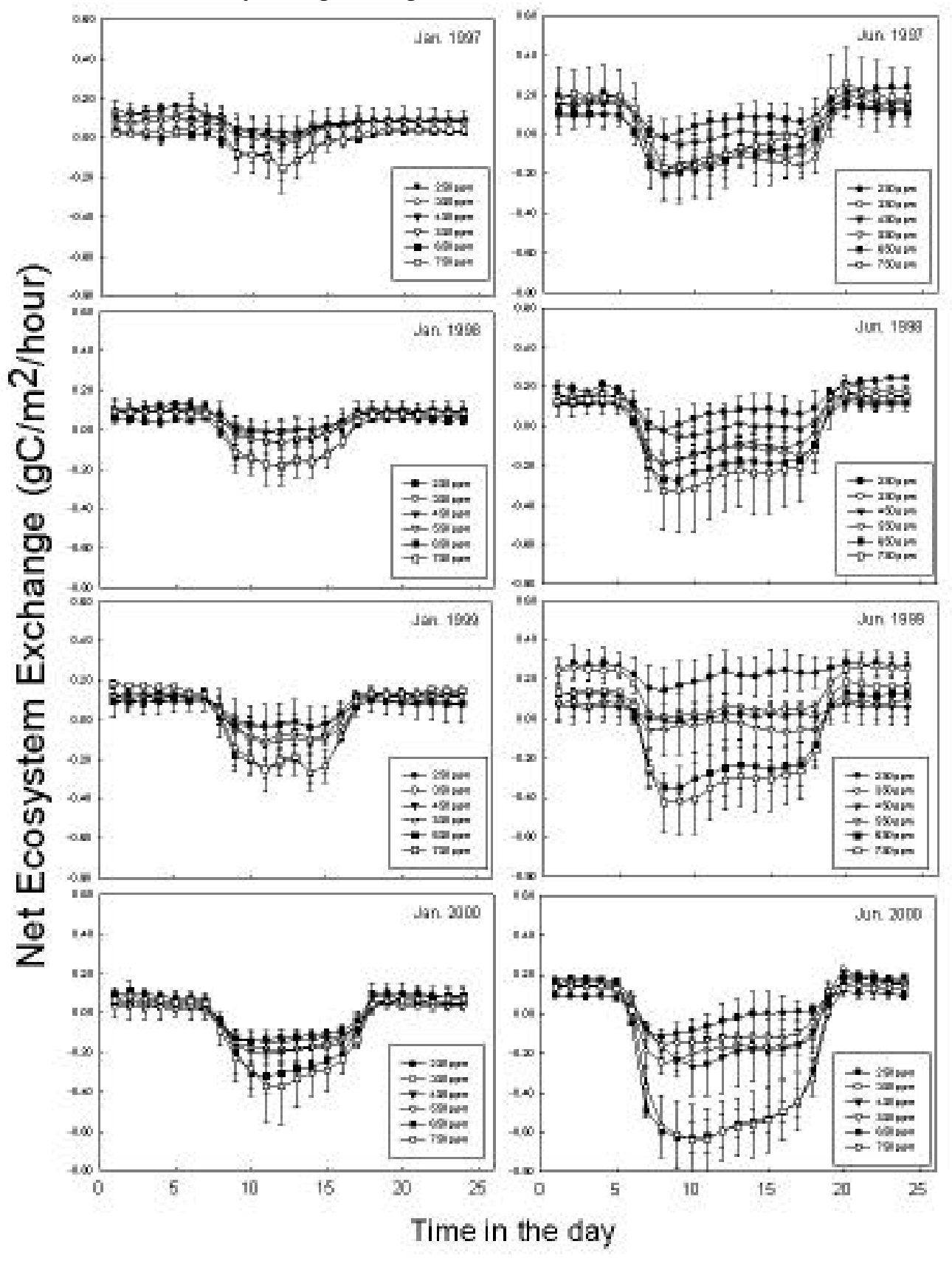


Figure 2. Mean $( \pm \mathrm{SE})$ annual net ecosystem exchange (NEE) fertilization effect $\left(\mathrm{gC} / \mathrm{m}^{2} / \mathrm{y}\right)$ verse growth $\mathrm{CO}_{2}$ treatment for chaparral ecosystem (dominated by Adenostoma fasciculatum with the age 5-8 years) in Sky Oaks of Southern California between 1997 to 2000. The $\mathrm{CO}_{2}$ fertilization effect is the difference between the annual NEE at different $\mathrm{CO}_{2}$ treatment and ambient treatment (350 ppm). Regression line and its $\mathrm{r}^{2}$ are showed in each graph for different year.

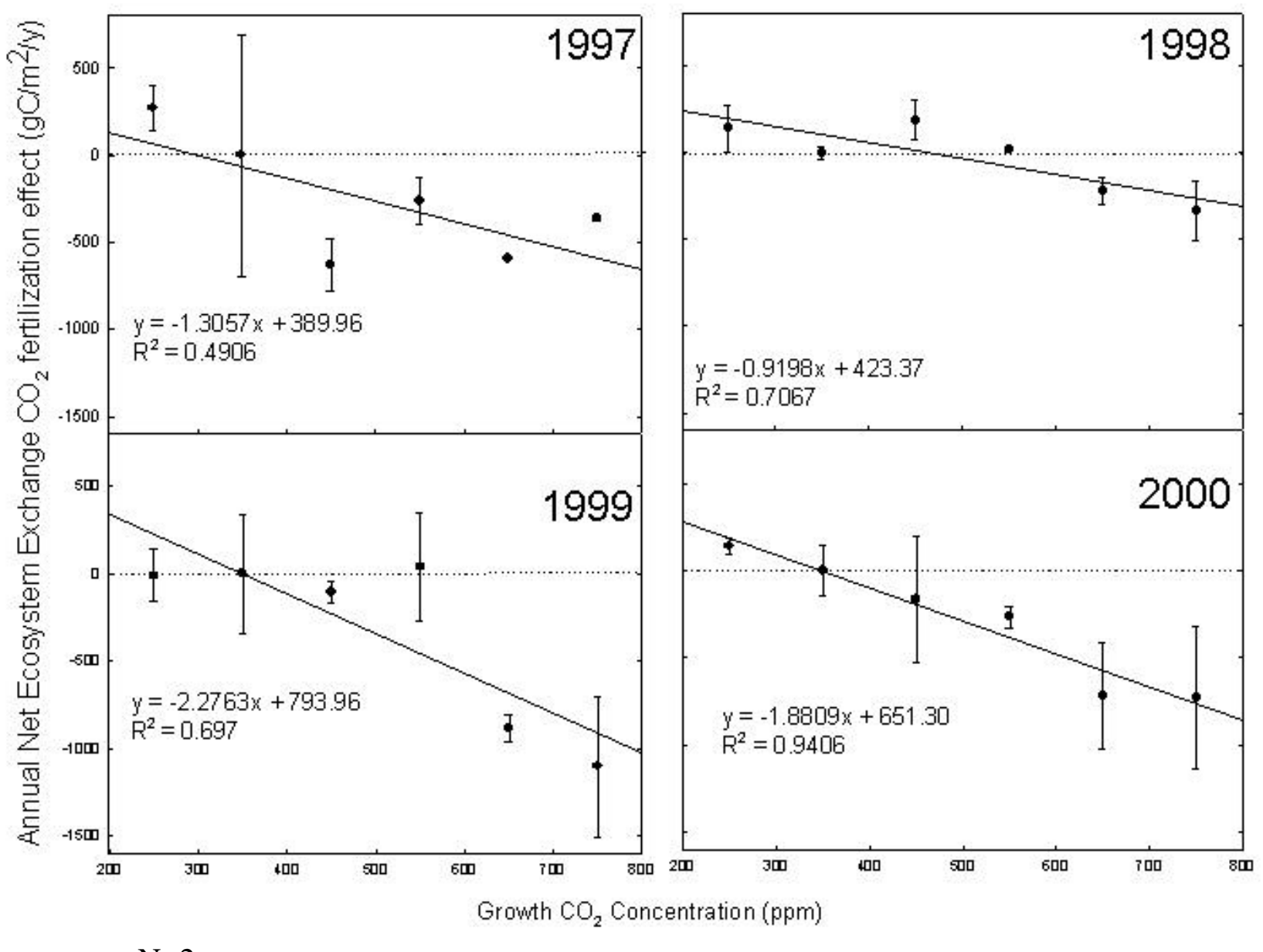

$\mathrm{N}=2$. 
Figure 3. Annual Gross Primary Productivity (GPP) $\left(\mathrm{gC} / \mathrm{m}^{2} / \mathrm{y}\right)$ verse growth $\mathrm{CO}_{2}$ treatment for chaparral ecosystem (dominated by Adenostoma fasciculatum with the age 5-8 years) in Sky Oaks of Southern California between 1997 to 2000.

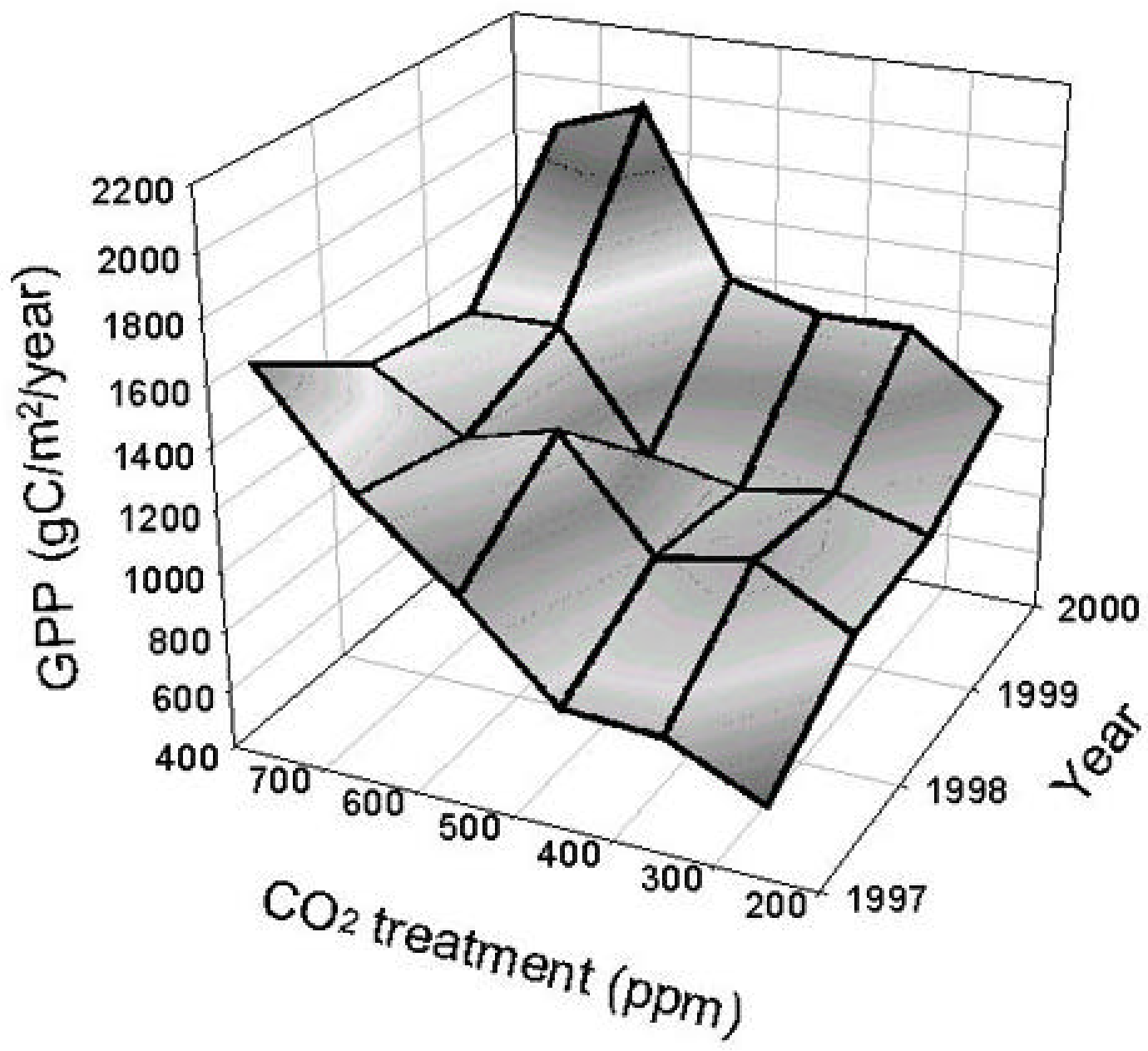


Figure 4. Monthly accumulative precipitation $(\mathrm{mm})$ in Sky Oaks Biological Field Station from the weather station near null balance chambers from January 1997 to December 2000. The annual precipitations are $415 \mathrm{~mm}, 725 \mathrm{~mm}, 247 \mathrm{~mm}$ and 234mm for year 1997, 1998, 1999 and 2000 respectively.

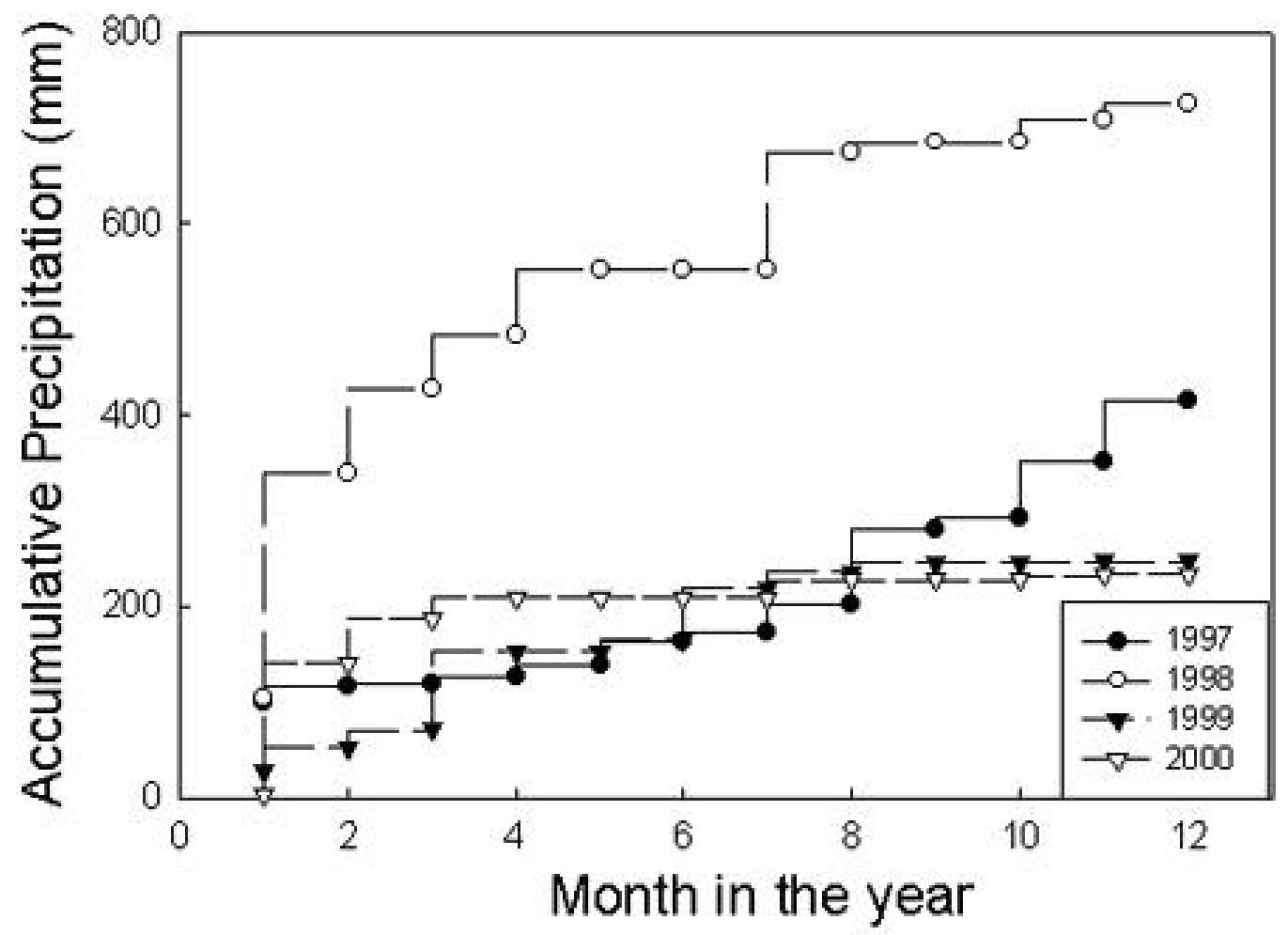


Figure 5. Mean \pm SE of predawn stem water potential measured by Pressure bomb under elevated $\mathrm{CO}_{2}\left(550 \mathrm{ppm}\right.$ treated by free air $\mathrm{CO}_{2}$ enrichment (FACE) and chambers) and ambient (by FACE control (C) and chambers maintained at 350ppm between 7-96 to 4-01. There is a significant season effect on the water potential $(\mathrm{p}=0000)$, no significant $\mathrm{CO} 2$ treat effect in both dry season (monthly precipitation less than medium) $(\mathrm{p}=0.074)$ and wet season (monthly precipitation greater than medium)

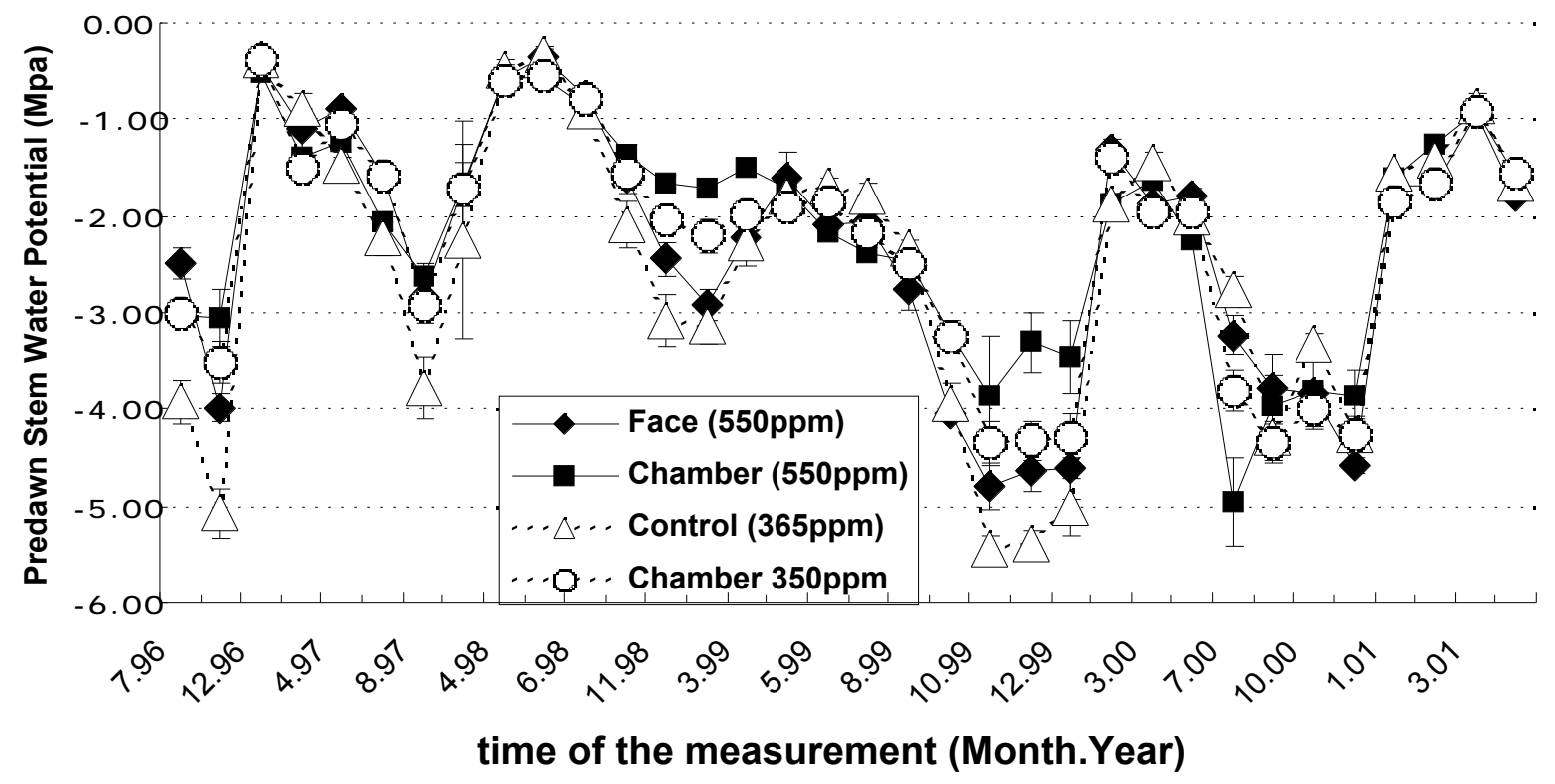

$(\mathrm{p}=0.055)$. 
Table 1. General linear model analysis (two-way ANOVA) of the annual NEE with $\mathrm{CO}_{2}$ treatment and annual precipitation effect and the $\mathrm{CO}_{2}$ cross year effect.

\begin{tabular}{|l|l|l|l|l|l|}
\hline Source & Sum-of-squares & $\mathrm{df}$ & Mean-Square & F-ratio & $\mathrm{P}$ \\
\hline Annual precipitation & 1295776.345 & 3 & 431925.448 & 3.639 & 0.027 \\
\hline Treat $\left(\mathrm{CO}_{2}\right)$ & 4017924.567 & 5 & 803584.913 & 6.771 & 0.000 \\
\hline Treat_Annual precipitation & 1535612.010 & 15 & 102374.134 & 0.863 & 0.609 \\
\hline
\end{tabular}


Table 2. Plant stem growth and leaf area index of Adenostoma fasciculatum individuals grown at different $\mathrm{CO}_{2}$ concentrations by $\mathrm{CO}_{2}$ null balance chambers.

\begin{tabular}{|c|c|c|c|c|c|c|c|c|c|}
\hline \multirow[b]{2}{*}{ parameter } & \multirow[b]{2}{*}{ year } & \multicolumn{6}{|c|}{ Growth $\mathrm{CO} 2$ concentration } & \multirow[b]{2}{*}{ P-Value } & \multirow[b]{2}{*}{ R-square } \\
\hline & & $250 \mathrm{ppm}$ & 350ppm & 450ppm & 550ppm & $650 \mathrm{ppm}$ & 750ppm & & \\
\hline \multirow{4}{*}{ Stem growth } & 1997 & 3.35 & 8.8 & 8.5 & 4.2 & 36.8 & 18.4 & 0.151 & 0.427 \\
\hline & 1998 & 7.25 & 5.27 & 9.3 & 5.61 & 9.39 & 4.51 & 0.752 & 0.016 \\
\hline & 1999 & 0.75 & 1.6 & 2.1 & 0.52 & 2.8 & 0.18 & 0.508 & 0.002 \\
\hline & 2000 & 1.25 & 2.17 & 4.34 & 0.62 & 4.9 & 2.37 & 0.479 & 0.010 \\
\hline \multirow{4}{*}{ leaf area index } & 1997 & 1.06 & 1.54 & 0.65 & 0.94 & 1.45 & 1.80 & 0.357 & 0.215 \\
\hline & 1998 & 1.25 & 2.33 & 1.05 & 1.37 & 2.08 & 1.64 & 0.203 & 0.027 \\
\hline & 1999 & 1.19 & 2.56 & 1.19 & 1.29 & 2.35 & 1.59 & 0.319 & 0.016 \\
\hline & 2000 & 1.09 & 2.29 & 1.23 & 1.30 & 2.44 & 1.62 & 0.403 & 0.087 \\
\hline
\end{tabular}




\section{Negative feedbacks on global change already exist from a Mediterranean-type ecosystem}

Rita Baraldi*, Francesca Rapparini*, Walter C. Oechel $\dagger$, Steve Hastings $\dagger$, Pablo Bryant $\dagger$, \& Franco Miglietta

* Institute of Biometeorology, National Research Council, Via Gobetti 101, 40129

Bologna, Italy

$\dagger$ Department of Biology, San Diego State University, San Diego, California 92182, USA

$\$$ Institute of Biometeorology, National Research Council, Via Caproni 8, 50145 Firenze, Italy

The increase in atmospheric $\mathrm{CO}_{2}$ of approximately $30 \%$ since the beginning of the industrial revolution (IPCC, 1995) and the potential links to recent and potential greenhouse warming (Mann, et al., 1998; Osborne et al., 2000) are well known. Much less certain are the feedbacks that could affect the rate of growth in atmospheric $\mathrm{CO}_{2}$ (Woodward, 2002), and its effectiveness in surface warming (IPCC, 1995; Gielen and Ceulemans, 2001). In this study we show that increases in atmospheric $\mathrm{CO}_{2}$ that have occurred in recent decades are sufficient to enhance net ecosystem carbon sequestration in a Mediterranean-type ecosystem as well as the rate of biogenic hydrocarbon emissions. This is the first report that $\mathrm{CO}_{2}$ increases since the industrial revolution are sufficient to have already increased biogenic volatile organic compound (BVOC) emissions which are relevant not only because of their impact on air quality, but because they are precursors to 
airborne particulates (aerosols). It is well recognized that aerosols can increase reflectance of incoming shortwave radiation and thereby act to cool the surface in opposition to the direct effects of greenhouse active trace gasses (Charlson et al., 1992; Russell, Hobbs and Stowe, 1999; Andreae and Crutzen, 1997). The enhancement of net ecosystem carbon sequestration also tends to provide a negative feedback on greenhouse warming. Critical to accurate prediction of future patterns of growth of $\mathrm{CO}_{2}$ in the atmosphere, and concomitant global warming, is a robust knowledge of feedbacks that may act to ameliorate this increase of atmospheric $\mathrm{CO}_{2}$, or its effectiveness in surface warming.

Mediterranean-type ecosystems are predicted to be especially sensitive to elevated $\mathrm{CO}_{2}$ and global climate change (Strain and Bazzaz, 1983; Moreno and Oechel, 1992) but their response to increasing atmospheric $\mathrm{CO}_{2}$ remains largely unexplored. In particular, the role of rising $\mathrm{CO}_{2}$ in the emission of biogenic volatile organic compounds is a subject of active debate since the production of these trace gasses by the vegetation is of importance for local and regional tropospheric ozone pollution and the occurrence of complex feedback effects on climate. This study analyzed the $\mathrm{CO}_{2}$ response of a regenerating chaparral ecosystem containing the resprouting shrub species Adenostoma fasciculatum, the most common species of the southern California chaparral, and the obligate seeder, Ceanothus greggii, a nitrogen fixer. This natural plant community regenerating after fire has been exposed for 4 consecutive years to $\mathrm{CO}_{2}$ concentrations from preindustrial $\left(250 \mu \mathrm{mol} \mathrm{mol}^{-1}\right)$ to double ambient $\left(750 \mu \mathrm{mol} \mathrm{mol}^{-1}\right) \mathrm{CO}_{2}$ levels in $100 \mu \mathrm{mol} \mathrm{mol}{ }^{-1}$ increments in naturally lit null-balance chambers (Oechel et al., 1992) 
configured to precisely track ambient conditions (except for the variable of study, $\mathrm{CO}_{2}$ ). During the measurement periods, Net Ecosystem Exchange (NEE) responded to higher treatment $\mathrm{CO}_{2}$ levels (Fig.1) with a positive linear increase. The ecosystem was a C-sink at the highest $\mathrm{CO}_{2}$ concentration both in December and in June. However, when exposed to sub-ambient and ambient $\mathrm{CO}_{2}$ concentrations these regenerating ecosystems were a small sink in June and a source in December. $\mathrm{CO}_{2}$ concentration was positively correlated with NEE both in autumn and in spring. In agreement with previous work, monoterpenes were the main biogenic hydrocarbons emitted by the plants in this study with only traces of isoprene (Winer et al., 1992). Eighteen different compounds were identified and are detailed in Table 1 with $\alpha$-pinene, camphene, $\beta$-myrcene, p-cymene and limonene, accounting for more than $70 \%$ of the total emission. The composition of the compounds emitted, as a fraction of the total emissions, was not affected by the $\mathrm{CO}_{2}$ concentration. Total trace gas emissions exhibited a diurnal pattern with increasing values in the morning and a maximum at midday (Fig.1). In winter, with maximum photosynthetically active radiation (PAR) of $1200 \mu \mathrm{mol} \mathrm{m}^{-2} \mathrm{~s}^{-1}$ and temperatures ranging from 0 to $14^{\circ} \mathrm{C}$, emission levels expressed on a ground area basis, were low $($ mean $=$ $1.04 \times 10^{-5} \mathrm{~g} \mathrm{~h}^{-1} \mathrm{~m}^{-2}$ ) and did not show any correlation with $\mathrm{CO}_{2}$ concentrations. However, in June, with higher light levels (PAR maximum of $2000 \mu \mathrm{mol} \mathrm{m}^{-2} \mathrm{~s}^{-1}$ ) and warmer temperatures (ranging from 15 to $30^{\circ} \mathrm{C}$ ) $\mathrm{BVOC}$ emissions were an order of magnitude greater $\left(\right.$ mean $=2.13 \times 10^{-4} \mathrm{~g} \mathrm{~h}^{-1} \mathrm{~m}^{-2}$ ) and responded positively to rising $\mathrm{CO}_{2}$ concentrations (Fig.1). Emission rates varied during the daytime but the cumulative daily emission increased with $\mathrm{CO}_{2}$ from $1.56 \times 10^{-3} \mathrm{~g} \mathrm{~m}^{-2}$ at $250 \mu \mathrm{mol} \mathrm{mol}^{-1}$ to $2.67 \times 10^{-3} \mathrm{~g} \mathrm{~m}^{-2}$ 
at $750 \mu \mathrm{mol} \mathrm{mol}^{-1} \mathrm{CO}_{2}$. Emission rates and NEE were well correlated throughout the day (Fig.1) while the overall carbon loss due to monoterpene emission was negligible ranging from 0.002 to $0.3 \%$ of the net carbon gain at the ecosystem level, independent of the season of measurement. Based on the experimental results, early summer production of reactive volatile organic compounds may have already increased by $15 \%$ since the beginning of the industrial revolution and NEE in the more productive early summer period should have almost doubled. Furthermore, the data indicate that BVOC emissions will be further enhanced by an additional $26 \%$ concomitantly with a four-fold increase in C-uptake in response to the predicted increment of atmospheric $\mathrm{CO}_{2}$, by another $50 \%$ in this century (Oechel et al., 1995).

The total annual estimated global emission of biogenic hydrocarbons of 1,150 $\mathrm{TgCyr}^{-1}$, dominates over anthropogenic non-methane organic emissions (Guenther et al., 1995) and the degradation of these reactive biogenic compounds affects directly and indirectly the atmospheric concentration of air pollutants and greenhouse gases such as ozone, carbon monoxide and methane (Fehsenfeld et al., 1992). Recent modeling simulations of the impact of VOC on tropospheric chemistry indicate that biogenic hydrocarbon oxidation increases the longevity of methane and carbon monoxide at the surface and, in the presence of air pollutants, almost doubles the net photochemical production of ozone in the troposphere (Poisson, Kanakidou and Cruzen, 2000). Biogenic emissions are of particular relevance in an environment characterized by high temperature and high radiation, typical of regions with Mediterranean-type climates (Seufert et al., 1995; Thunis and Cuvelier, 2000). These areas are often well populated or 
over populated because of the favorable climatic conditions and, accordingly, are already known to be major source of anthropogenic pollutants capable of promoting the chemical transformation of VOCs leading to photochemical pollution. It is therefore obvious that if the stimulation of anthropogenic and biogenic VOC emissions that have occurred in the recent past continue in the future, there will likely be serious consequences for mean tropospheric ozone concentrations. On the other hand, a significant atmospheric aerosolforming potential of the most prevalent biogenic hydrocarbons has been established and characterized under simulated laboratory conditions (Griffin et al., 1999; Hoffman et al., 1997; Virkkula et al., 1999). Moreover, in situ experiments of gaseous and particulate atmospheric species demonstrated that under natural atmospheric conditions, photooxidation of terpenes yields relatively non-volatile secondary products (i.e. organic acids) which condense to form organic aerosols (Yu et al., 1999; Pio, Alves, and Duarte, 2001; Kavouras, Mihalopoulos and Stephanou, 1998; 1999; Kanakidou et al., 2000). These airborne particles affect climate by scattering and absorbing solar shortwave radiation and thus generating feedback mechanisms for the planetary radiation balance (Dowd, 2001). Model calculations indicate that aerosols can cause a net negative climate forcing (cooling of the atmosphere) which could partially offset the current anthropogenic greenhouse gas warming of the atmosphere (Climate Change, 1994).

In conclusion, a predicted increase of BVOC flux to the atmosphere on the order of $5 \%$ per decade will potentially trigger photochemical reactions of the unsaturated hydrocarbons. These changes will affect the oxidative balance of the troposphere, the photochemical ozone formation and the secondary organic aerosol production. While 
relative growth rates are unknown, these increases in BVOC are in addition to any increases in anthropogenic VOC emissions over the coming decades, and both sources of increases in VOC are likely to be significant.

Methods

Measurements of the volatile organic compounds were made by collecting 2-31 of the air surrounding the vegetation grown inside the chambers into two-stage glass traps. Sampling was carried out in the morning, at midday and in the afternoon to follow the diurnal course of the emissions and repeated for three days in June and December. Separation, identification and quantification of the collected hydrocarbons were done by means of thermal desorption gas chromatography and mass spectrometry (Baraldi et al., 1999). Environmental control and $\mathrm{CO}_{2}$ manipulation were conducted in null balance, environmentally controlled, field chambers similar to those previously described (Oechel et al., 1992; Oechel et al., 2001). Response of BVOC emissions are a combination of overall plant response to elevated $\mathrm{CO}_{2}$, and include effects of growth $\mathrm{CO}_{2}$ on emission rates and leaf area development. A similar combination of responses, and a similar net response is expected in nature. However, changes in temperature would be expected to exacerbate the effect reported here. Changes in species composition with climate change which changes the mix of BVOC emitting species to relatively non-emitting species would also effect the emissions under expected future conditions. 
Andreae, M.O. \& Crutzen, P.J. Atmospheric aerosols: Biogeochemical sources and role in atmospheric chemistry. Science, 276, 1052-1058, (1997).

Baraldi, R., Rapparini, F., Rossi, F., Latella, A. \& Ciccioli, P. Volatile organic compound emissions from flowers of the most occurring and economically important species of fruit trees. Phys. Chem. Earth (B), 24, 729-732, (1999).

Charlson, R.J., Schwartz, S.E., Hales, J.M., Cess, R.D., Coakley, Jr J.A., Hansen, J:E: \& Hoffman, D.J. Climate forcing by anthropogenic aerosols. Science, 255, 423-430, (1992).

Climate Change 1994, Radiate forcing of climate change and an evaluation of the IPCC IS92 Emission Scenarios (eds Houghton, J.T., Meira Filho, L.G., Bruce, J., Lee, H., Callender, B.A., Haites, H., Harris, N. \& Maskell, K.) (Cambridge Uni. Press, Cambridge 1995).

Climate Change 1995: IPCC Second Assessment Report. The Science of Climate Change (eds Houghton, J.T., Meira Filho, L.G., Callander, B.A., Harris, N., Kattenberg, A. P. \& Marskell, K.) 21-24 (Cambridge Uni. Press, Cambridge, 1995).

Dowd, C.D. Biogenic coastal aerosol production and its influence on aerosol radiative properties. J Geophys. Res., 106, 1545-1549, (2001).

Fehsenfeld, F., Calvert, J., Fall, R., Goldan, P., Guenther, A:B:, Hewitt, C.N., Lamb, B., Liu, S., Trainer, M., Westberg, H. \& Zimmerman, P. Emissions of volatile organic compounds from vegetation and the implications for atmospheric chemistry. Global Biogeochem. Cycles, 6, 4, 389-430, (1992).

Gielen, B. \& Ceulemans, R. The likely impact of rising atmospheric $\mathrm{CO} 2$ on natural and managed Populus: a literature review. Envir. Poll., 115, 335-358 (2001).

Griffin, R.J., Cocker III, D.R., Flagan, R.C., \& Seinfeld, J.H.. Organic aerosol formation from the oxidation of biogenic hydrocarbons. J. Geophys. Res., 104, 3555-3567, (1999)

Guenther, A., Hewitt, C., Erickson, D., Fall, R., Geron, C., Graedel, T., Harley, P., Klinger, L., Leardeau, M., Mc Kay, W., Pierce, T., Scholes, B., Steinbrecher, R., Tallamraju, R., Taylor, J. \& Zimmerman, P. A global model of natural volatile organic compound emissions, J. Geophys. Res., 100, 8873-8892, (1995).

Hoffman, T., Odum, J.R., Bowman, F., Collins, D., Klockow, D., Flagan, R.C. \& Seinfeld, J.H. Formation of organic aerosols from the oxidation of biogenic hydrocarbons. J. Atmos. Chem., 26, 189-222, (1997).

Kanakidou, M., Tsigaridis, K., Dentener, F.J. \& Crutzen, P.J. Human-activity-enhanced formation of organic aerosols by biogenic hydrocarbon oxidation. J. Geophys. Res., 105, 9243-9254, (2000).

Kavouras, I.G., Mihalopoulos, N. \& Stephanou, E.G. Formation of atmospheric particles from organic acids produced by forests. Nature, 395, 683-686, (1998).

Kavouras, I.G., Mihalopoulos, N. \& Stephanou, E.G. Secondary organic aerosol formation vs primary organic aerosol emission: In situ evidence for the chemical coupling between monoterpene acidic photooxidation products and new particle formation over forests. Environ. Sci. Technol., 33, 1028-1037, (1999). 
Mann, M.E., Bradley, R.S. \& Hughes, M.K. Global-scale temperature patterns and climate forcing over the past six cen turies. Nature, 392, 779-787, (1998).

Moreno, J.M. \& Oechel, W.C. Factors controlling postfire seedling establishment in southern california chaparral. Oecol., 90 (1), 50-60, (1992).

Oechel, W.C., Hastings, S.J., Vourlitis, G.L., Jenkins, M.A. \& Hinkson, C.L. in Global Change and Mediterranean-type ecosystems (eds Moreno, J.M. \& Oechel W.C.) 58-75 (Springer-Verlag New York, Inc. 1995)

Oechel, W.C., Riechers, G., Lawrence, W.T., Prudhomme, T.I., Grulke, N. \& Hastings, S.J. CO2LT", A Closed, Null-balance System for Long-term in situ Ecosystem Manipulation and Measurement of CO2 Level, CO2 Flux, and Temperature. Funct. Ecol., 6, 86-100, 1992

Oechel, W.C., Vourlitis, G.L., Hastings, S.J., Zulueta, R.C., Hinzman, L. \& Kane, D. Long-term ecosystem CO2 flux measurements in the Alaskan Arctic show acclimation to decadal climate warming. Nature, 406, 978-981, 2000.

Osborne, C.P., Mitchell P.L., Sheehy, J.E. \& Woodward, F.I. Modelling the recent impacts of atmospheric $\mathrm{CO} 2$ and climate change on Mediterranean vegetation. Global Change Biol., 6, 445-458, (2000).

Pio, C., Alves, C. \& Duarte, A. Organic components of aerosols in forested area of central Greece. Atmos. Environ., 35, 389-401, (2001).

Poisson, N., Kanakidou, M. \& Crutzen, P.J. Impact of non-methane hydrocarbons on tropospheric chemistry and the oxidizing power of the global troposphere: 3dimensional modelling results. J. Atmos. Chem., 36, 157-230, (2000).

Russell, P.B., Hobbs, P.V. \& Stowe, L.L. Aerosol properties and radiate effects in the United State East Coast haze plume: An overview of the tropospheric aerosol radiate forcing experiment (TARFOX). J. Geophys. Res. 104, 2213-2222, (1999).

Seufert G., Kotzias, Spartà, D.C. \& Versino, B. in Global Change and Mediterraneantype ecosystems (eds Moreno, J.M. \& Oechel W.C.) 343-370 (Springer-Verlag New York, Inc. 1995)

Strain, B.R. \& Bazzaz, F.A. in $\mathrm{CO}_{2}$ and Plants: The Response of Plants to Rising Levels of Atmospheric Carbon Dioxide (ed Lemon, E.R.) 177-222 (Westview Press, Boulder, 1983).

Thunis, P. \& Cuvelier, C. Impact of biogenic emissions on ozone formation in the Mediterranean area - a BEMA modelling study. Atmos. Envir., 34, 467-481, (2000)

Virkkula, A., Van Dingenen R., Raes, R., Hjorth, J. Hygroscopic properties of aerosol formed by oxidation of limonene, $\alpha$-pinene, and $\beta$-pinene. J. Geophys. Res., 104, 3569-3579, (1999).

Winer, A.M., Arey, J., Atkinson, R., Aschmann, S.M., Long, W.D., Morrison, C.L. \& Olszyk, D.M. Emission rates of organics from vegetation in California's central valley. Atm. Environ., 26A, 14, 2647-2659, (1992).

Woodward, F.I. Potential impact of global elevated CO2 concentrations on plants. Current Opinion in Plant Biol., 5, 207-211, (2002). 
Yu, J., Griffin, R.J., Cocker III, D.R., Flagan, R.C. \& Seinfeld, J.H. Observation of gaseous and particulate products of monoterpene oxidation in forest atmospheres. Geophys. Res. Lett.,26 (8), 1145-1148, (1999)

\section{Acknowledgements}

The construction of the null balance $\mathrm{CO}_{2}$ controlled, ambient temperature tracking (CO2LT) chambers, and four years of $\mathrm{CO}_{2}$ manipulation and analysis were supported by grants from the Department of Energy's PER Program, NIGEC's WESTGEC, Southern California Edison, Electric Power Research Institute (EPRI), San Diego State University, and the San Diego State University Foundation. Sampling and analysis of BVOC emissions reported here were supported by CNR $\backslash$ and by DOE's PER Program,DE-FG03 93 ER 61715. This support is gratefully acknowledged. 
Table 1. Percent composition of volatile organic compounds identified in chaparral emissions

\begin{tabular}{|l|l|l|}
\hline Compounds & $\begin{array}{l}\text { December } \\
1999(\%)\end{array}$ & $\begin{array}{l}\text { June } \\
2000(\%)\end{array}$ \\
\hline Isoprene & $0.9 \pm 0.1$ & $3.8 \pm 1.0$ \\
\hline$\alpha$-thujene & $0.6 \pm 1.1$ & $3.6 \pm 1.8$ \\
\hline$\alpha$-Pinene & $22.0 \pm 1.6$ & $22.3 \pm 1.1$ \\
\hline Camphene & $16.0 \pm 1.5$ & $12.7 \pm 2.0$ \\
\hline Sabinene & $5.7 \pm 1.0$ & $4.2 \pm 1.9$ \\
\hline$\beta$-Pinene & $5.2 \pm 0.1$ & $4.3 \pm 0.9$ \\
\hline$\beta$-Myrcene & $2.4 \pm 0.1$ & $11.2 \pm 1.1$ \\
\hline$\alpha$-Phellandrene & $0.1 \pm 0.1$ & $1.0 \pm 0.1$ \\
\hline$\Delta 3$-Carene & $0.3 \pm 0.1$ & $0.2 \pm 0.1$ \\
\hline$\alpha$-Terpinene & $0.4 \pm 0.1$ & $0.7 \pm 0.3$ \\
\hline$\rho$-Cymene & $2.5 \pm 0.1$ & $16.3 \pm 3.2$ \\
\hline$\beta$-Phellandrene & $0.5 \pm 0.1$ & $1.6 \pm 0.2$ \\
\hline Limonene & $37.0 \pm 2.5$ & $12.9 \pm 1.2$ \\
\hline Cis-o-cymene & $0.2 \pm 0.1$ & $0.5 \pm 0.1$ \\
\hline Trans-o-cymene & $0.3 \pm 0.2$ & $1.0 \pm 0.3$ \\
\hline$\gamma$-Terpinene & $1.0 \pm 0.3$ & $2.1 \pm 0.6$ \\
\hline$\alpha$-Terpinolene & $0.3 \pm 0.1$ & $0.8 \pm 0.2$ \\
\hline Linalool & $0.4 \pm 0.2$ & $0.4 \pm 0.1$ \\
\hline Camphor & $0.6 \pm 0.1$ & $0.3 \pm 0.1$ \\
\hline
\end{tabular}


December 1999

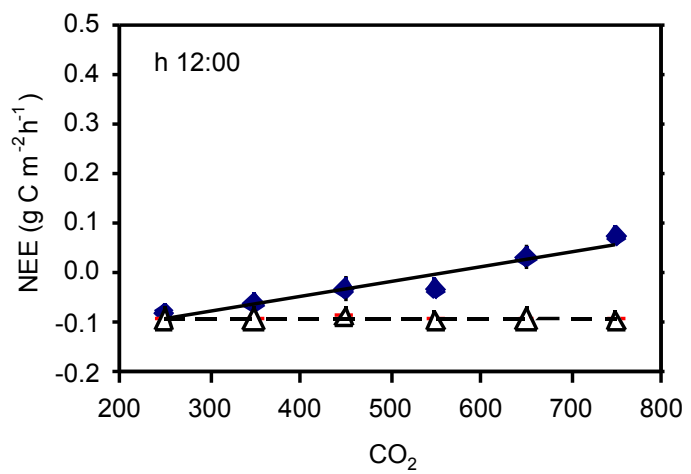

Figure 1 Effects of $\mathrm{CO} 2$ concentrations on Net Ecosystem Productivity $(\bullet)$ and overall BVOC emissions $(\Delta)$ measured at different hours of the day in December 1999 and June 2000.

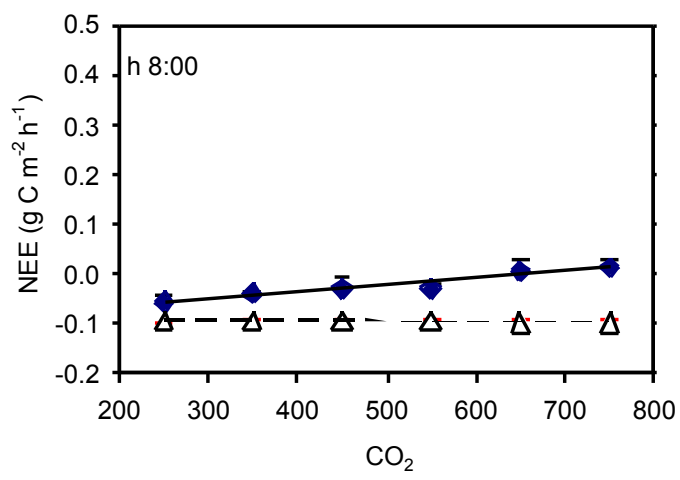

June 2000
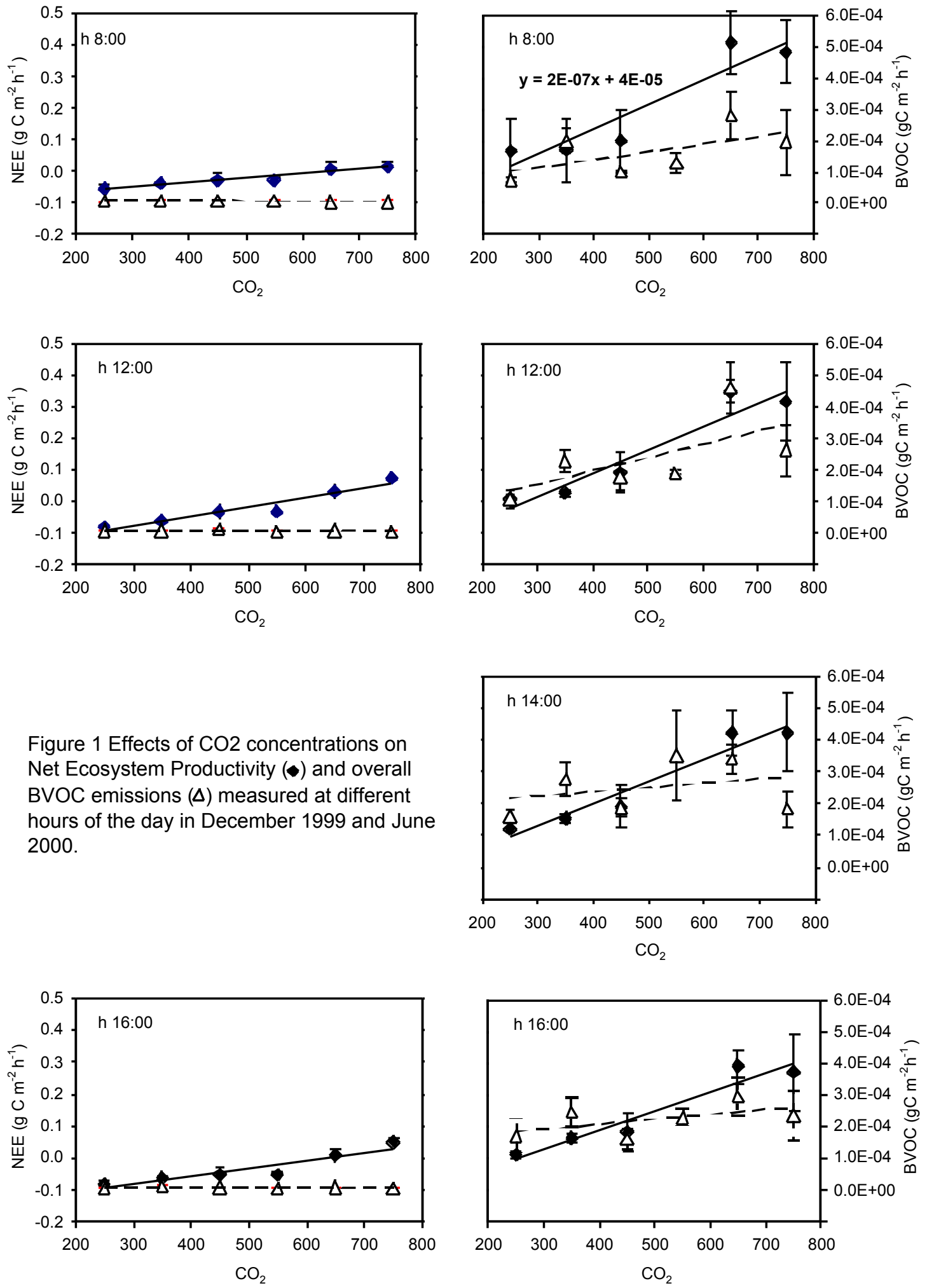
${ }^{13} \mathrm{C}$ tracers of carbon allocation to roots under a $\mathrm{CO}_{2}$ gradient in intact southern Californian chaparral

Kathleen K. Treseder ${ }^{1}$, Yufu Cheng ${ }^{2}$, Michael F. Allen ${ }^{3}$, and Walter C. Oechel ${ }^{4}$

${ }^{1}$ Dept. of Biology, University of Pennsylvania

${ }^{2}$ Division of Evolution and Ecology, University of California Davis

${ }^{3}$ Center for Conservation Biology, University of California Riverside

${ }^{4}$ Dept. of Biology, San Diego State University

\begin{abstract}
We examined root dynamics in intact chaparral exposed for 3.5 years to atmospheric $\mathrm{CO}_{2}$ levels ranging from subambient (250-ppm) to more than twice ambient (750-ppm) in 100-ppm intervals. Because the fossil fuel-derived $\mathrm{CO}_{2}$ used for $\mathrm{CO}_{2}$ enrichment was depleted in ${ }^{13} \mathrm{C}$ relative to the atmosphere, stable isotope tracers allowed us to tease apart the fates of carbon fixed before and after the inception of $\mathrm{CO}_{2}$ enrichment. Bulk root biomass (including both live and dead roots) increased 7-fold with elevated $\mathrm{CO}_{2}$, and this increase was significantly more pronounced in the upper soil layers. The factors underlying this increase appeared to vary with $\mathrm{CO}_{2}$ level. Based on root signatures of ${ }^{13} \mathrm{C}$, accumulation of recently-fixed root $\mathrm{C}$ in the highest (750-pm) treatment seemed to contribute to relatively high bulk root carbon, potentially due to increased production of roots constructed after initiation of the experiment or reduced turnover of new roots. In contrast, a relatively high accumulation of older $\mathrm{C}$ in roots appeared to raise bulk root carbon in intermediate (450- and 550-ppm) $\mathrm{CO}_{2}$ treatments. Root diameters declined significantly with increasing $\mathrm{CO}_{2}$, from 0.53 - to $0.34-\mathrm{mm}$ in the
\end{abstract}


250- and 750-ppm treatments, respectively. The relatively large $\mathrm{CO}_{2}$ effect in chaparral may be attributable to the arid nature of this environment and may have a marked effect on contribution of roots to soil $\mathrm{C}$ dynamics in chaparral.

Keywords: ${ }^{13} \mathrm{C}$ stable isotopes, chaparral, elevated $\mathrm{CO}_{2}$, root biomass, soil carbon 


\section{Introduction}

Numerous studies have examined effects of elevated atmospheric $\mathrm{CO}_{2}$ on root dynamics in crop systems, forests, and grasslands. The majority report increases in root biomass or production (reviewed in Bazzaz 1990; Berntson and Bazzaz 1996; Pritchard and Rogers 2000; Rogers et al. 1992; Rogers et al. 1994; Tingey et al. 2000) with some exceptions (Arnone et al. 2000). Responses of other systems to $\mathrm{CO}_{2}$ manipulation are less well understood, especially for long-term field-based experiments (Norby 1994). Arid and semi-arid lands, in particular, constitute about $16 \%$ of net primary production and can be important components of global carbon cycling (Roberts et al. 1998). Natural ecosystems in the southwestern United States, such as southern Californian chaparral, can be particularly water-limited; net primary productivity (below- and above-ground) here may respond strongly to increases in water use efficiency typically conferred by $\mathrm{CO}_{2}$ enrichment (Bazzaz 1990). It is also possible that any augmentation of plant growth may enhance demand for water (Berntson and Woodward 1992), with a consequent downward shift in the vertical distribution of roots in chaparral to access deeper water sources. Mean root diameter may also decrease to improve foraging efficiency for water (Norby 1994; Tingey et al. 1995). These potential changes in the allocation of biomass belowground could alter soil carbon dynamics, and, potentially, carbon storage (Norby 1994; Rogers et al. 1994; Van Kessel et al. 2000a; Van Kessel et al. 2000b) and are considered in global change models (Woodward and Osborne 2000).

Documented changes in standing root biomass could be a result of several factors, including increased root production, increased longevity, or decreased decomposition 
rates (Pregitzer et al. 1995; Tingey et al. 2000). Studies that have explicitly measured root growth generally have reported increases in woodlands (Pregitzer et al. 1995; Tingey et al. 2000) and crops (Pritchard and Rogers 2000; Rogers et al. 1992), but not necessarily in native grasslands (Arnone et al. 2000). Moreover, increases in biomass or production can occur disproportionately in the top layers of soil in crop plants (Chaudhuri et al. 1990; Prior et al. 1994; Pritchard and Rogers 2000) natural grasslands (Arnone et al. 2000), forests (Larigauderie et al. 1988), and other systems, though not always (Berntson and Woodward 1992; Chaudhuri et al. 1986; Rogers et al. 1992; Thomas et al. 1999). Root longevity and decomposition rate tend to vary in response to elevated $\mathrm{CO}_{2}$ (Allen et al. 2000; Johnson et al. 2000; Pregitzer et al. 2000; Thomas et al. 1999; Verburg et al. 1998), and generalizations at this point are difficult (Arnone et al. 2000; Pritchard and Rogers 2000). As such, static measures of root biomass provide only a limited understanding of mechanisms underlying $\mathrm{CO}_{2}$ effects on belowground biomass and carbon storage (Pritchard and Rogers 2000).

Because the fossil fuel-derived $\mathrm{CO}_{2}$ used in studies of $\mathrm{CO}_{2}$ enrichment is depleted in ${ }^{13} \mathrm{C}$ relative to the atmosphere, stable isotope tracers allow us to tease apart the fates of carbon fixed before and after the inception of $\mathrm{CO}_{2}$ enrichment (Hungate et al. 1996; Nitschelm et al. 1997; Van Kessel et al. 2000a; Van Kessel et al. 2000b). With this approach, we may focus on the integrated allocation to roots of recently acquired $\mathrm{C}$ and assess changes in root processes in addition to changes in root biomass. We examined root dynamics in intact chaparral exposed for 3.5 years to atmospheric $\mathrm{CO}_{2}$ levels ranging from subambient (250-ppm) to more than twice ambient (750-ppm) in 100-ppm intervals. 
This experimental design conferred novel aspects to our study by allowing us to consider plant responses over $\mathrm{CO}_{2}$ concentrations ranging from pre-Industrial Revolution levels to those anticipated to occur within the next century. In addition, since all treatments received ${ }^{13} \mathrm{C}$-depleted $\mathrm{CO}_{2}$ to stabilize $\mathrm{CO}_{2}$ levels, we were able use stable isotopes of carbon as a tracer at even the lower $\mathrm{CO}_{2}$ concentrations; stable isotope analyses in most other $\mathrm{CO}_{2}$ studies have been restricted to the $\mathrm{CO}_{2}$-enriched treatments only. We hypothesized that elevated $\mathrm{CO}_{2}$ would (1) increase root biomass, (2) shift root allocation to deeper soil layers, (3) reduce root diameter, and (4) increase allocation of recentlyfixed carbon to roots.

\section{Materials and methods}

Site

The Sky Oaks $\mathrm{CO}_{2}$ enrichment study (operated by San Diego State University) is located near Temecula, California in chaparral vegetation dominated by Adenostoma fasciculatum (chemise) shrubs. Twelve closed 2- x 2- x 2-m chambers are each centered around an individual of Adenostoma and its surrounding herbaceous plants. Atmospheric $\mathrm{CO}_{2}$ concentrations within the chambers are maintained at levels ranging from 250- to 750-ppm in 100-ppm increments, with two replicates for each treatment. Ambient $\mathrm{CO}_{2}$ levels are about 360-ppm. Concentrations of $\mathrm{CO}_{2}$ are measured every three minutes, and $\mathrm{CO}_{2}$ is scrubbed or augmented to maintain appropriate levels. As a result, $\mathrm{CO}_{2}$ is occasionally added to even the lower $\mathrm{CO}_{2}$ levels. The chambers are naturally lit (about 93\% of ambient), and temperature is maintained near ambient (Oechel et al. 1992). 
Precipitation is collected from the chamber roof and channeled inside to the soil surface through several small tubes. The site was burned in 1992, and $\mathrm{CO}_{2}$ enrichment started in December 1995.

\section{Sample collection}

In October 1999, we obtained soil from the chambers with 4-cm diameter corers for measurements of root biomass. One core was collected from underneath the canopy of each Adenostoma at 5-, 10-, 20-, 30-, 40-, 50-, 60-, 70-, and 80-cm depths. Samples were stored on ice for transport back to the laboratory.

\section{Root sampling}

Root collections were made to measure the bulk (live + dead) biomass of roots in the each layer of soil. In addition, bulk and live roots from the 5-cm depth samples were subjected to stable isotope analyses, measurements of carbon concentrations, and assessments of root diameter. To obtain live Adenostoma roots (as an estimate of the ${ }^{13} \mathrm{C}$ signature of recently-fixed C), we used forceps to sift through whole soil and pull out any roots encountered. These roots were washed three times in deionized water. At least five live Adenostoma roots < 1-mm diameter were selected from each sample based on color, morphology, and texture, and these were oven-dried at $60{ }^{\circ} \mathrm{C}$ for $72 \mathrm{hrs}$, and isotopic signatures were measured as described below. We could not collect enough root material from one of the 550-ppm chambers to measure ${ }^{13} \mathrm{C}$ accurately, so we report only one replicate for that treatment. To determine pre-treatment ${ }^{13} \mathrm{C}$ signatures of root material, we also selected live Adenostoma roots from five soil cores obtained from an undisturbed area about 50-m from the chambers. 
To obtain roots for biomass measures, soil samples were sieved through 1-mm mesh, and material remaining on the sieve was examined. Root fragments greater than 4-mm in length were selected regardless of condition or species identity. These roots were washed three times in deionized water. A precision caliper was used to measure the diameter of each root from the $5-\mathrm{cm}$ depth samples. All roots were then oven-dried at $60{ }^{\circ} \mathrm{C}$ for 72 hrs and weighed. Root biomass at each depth was calculated as dry weight per unit area of soil. Roots from the 5-cm depth samples were then analyzed for ${ }^{13} \mathrm{C}$ content and $\% \mathrm{C}$ as detailed below.

\section{Stable isotope analyses and calculations}

To determine $\mathrm{d}^{13} \mathrm{C}$ and $\% \mathrm{C}$ of roots, oven-dried samples were ground to a fine mesh, enclosed in tin capsules, and run through a continuous flow mass spectrometer coupled with a gas chromatograph and elemental analyzer (Europa Integra, Stable Isotope Facility, University of California - Davis). $\mathrm{d}^{13} \mathrm{C}$ is calculated as $\left[\left({ }^{13} \mathrm{C} /{ }^{12} \mathrm{C}_{\text {sample }}\right) /\left({ }^{13} \mathrm{C} /{ }^{12} \mathrm{C}_{\text {standard }}\right)-1\right] \times 1000 \%$, where ${ }^{13} \mathrm{C} /{ }^{12} \mathrm{C}_{\text {sample }}$ and ${ }^{13} \mathrm{C} /{ }^{12} \mathrm{C}_{\text {standard }}$ are the isotope ratios of the sample and standard (Pee Dee Belemnite), respectively (Ehleringer and Osmond 1991).

The tank $\mathrm{CO}_{2}$ added to the chambers was derived from fossil fuels, which are depleted in ${ }^{13} \mathrm{C}$ relative to the atmosphere $\left(\mathrm{d}^{13} \mathrm{C}\right.$ of added $\mathrm{CO}_{2}$ : $-20 \%$; atmospheric $\mathrm{CO}_{2}$ : $-8 \%$ ). This difference in isotopic signature enabled us to trace the $\mathrm{C}$ that had been added to the system during the $\mathrm{CO}_{2}$ experiment (referred to as "new C"). We used a mass balance equation to calculate the amount of new $\mathrm{C}$ in bulk roots. The $\mathrm{d}^{13} \mathrm{C}$ signature of belowground $\mathrm{C}$ in each treatment can be represented as a linear equation in which the 
mean $\mathrm{d}^{13} \mathrm{C}$ of live Adenostoma roots from each chamber is used as the signature of the "new" C (fixed since onset of experiment) and the mean $\mathrm{d}^{13} \mathrm{C}$ of live roots from a nearby undisturbed area represents the "old" $\mathrm{C}$ (fixed before $\mathrm{CO}_{2}$ enrichment):

$$
\mathrm{d}^{13} \mathrm{C}_{\text {bulk roots }}=\left[\left(\mathrm{d}^{13} \mathrm{C}_{\text {old }} * \% \text { old } \mathrm{C}\right)+\left(\mathrm{d}^{13} \mathrm{C}_{\text {new }} * \% \text { new } \mathrm{C}\right)\right] / 100,
$$

where $\mathrm{d}^{13} \mathrm{C}_{\text {bulk roots }}$ is the signature of live + dead roots; $\mathrm{d}^{13} \mathrm{C}_{\text {old }}$, the isotopic composition of old $\mathrm{C} ; \mathrm{d}^{13} \mathrm{C}_{\text {new }}$, the signature of new $\mathrm{C} ; \%$ old $\mathrm{C}$, the proportion of $\mathrm{C}$ that is old; and \%new $\mathrm{C}$, the proportion of $\mathrm{C}$ that is new. Total amounts of old versus new $\mathrm{C}$ in bulk roots were estimated using percent new $\mathrm{C}$ and measurements of root biomass and \%C:

$$
\text { New C }=(\% \text { newC/100) } *(\% \mathrm{C} / 100) *(\text { biomass }) *(\text { depth }) \text {, }
$$

where \%newC represents the percentage of root $\mathrm{C}$ that is new; \% $\mathrm{C}$, the concentration of $\mathrm{C}$ in roots; biomass, live + dead root weight $\left(\mathrm{g} / \mathrm{cm}^{2}\right)$; and depth, the depth to which soil was collected $(5-\mathrm{cm})$. Old $\mathrm{C}$ is calculated as total root $\mathrm{C}$ minus new root $\mathrm{C}$. This tracer method has some limitations - the live roots we selected to represent the signature of new $\mathrm{C}$ may include some roots present before the onset of $\mathrm{CO}_{2}$ enrichment 3.5 years earlier. Alternately, stored old C may have been transferred to live roots grown during the experiment. In either case, we would overestimate to amount of new $\mathrm{C}$ in bulk roots. In addition, the stable isotope approach would not detect $\mathrm{C}$ that had both entered and exited the system during the experiment.

\section{Statistics}

Relationships between each dependent variable (e.g. root biomass, root $\mathrm{d}^{13} \mathrm{C}$, etc.) and $\mathrm{CO}_{2}$ concentration were tested though linear or non-linear regression analyses using Systat10 (SPSS 2000b) and SigmaPlot 2000 (SPSS 2000a). For root diameter, the mean 
from each chamber was used for the regression. To test for significant depth by $\mathrm{CO}_{2}$ interactions on bulk root biomass, data were ranked and subjected to a fully factorial analysis of variance (ANOVA) with $\mathrm{CO}_{2}$ and depth as independent variables and biomass as the dependent variable. We also performed linear regressions separately on samples from each depth. To display results, we grouped samples by $20-\mathrm{cm}$ depths $(0-$ to $20-\mathrm{cm}$, 20- to 40-cm, etc.). We employed a Kruskal-Wallis test to assess significant differences in ${ }^{13} \mathrm{C}$ signatures among bulk roots, live roots, and roots from the undisturbed area. Pairwise comparisons were conducted using a Kolmogorov-Smirnov test. In all cases, results were considered significant when $\mathrm{P}<0.05$.

\section{Results}

\section{Biomass, carbon content, and morphology of bulk roots}

Bulk root biomass (including both live and dead roots) increased with elevated $\mathrm{CO}_{2}$, and this increase was significantly more pronounced in the upper soil layers. Total biomass (0- to 80-cm) rose significantly and 7-fold with increasing $\mathrm{CO}_{2}$ (Fig. 1a; $\mathrm{P}<$ $\left.0.015 ; \mathrm{r}^{2}=0.510\right)$. Specifically, root biomass increased significantly at 0 - to 5 -cm (Fig. $\left.1 \mathrm{~b} ; \mathrm{P}<0.046 ; \mathrm{r}^{2}=0.341\right)$ and at $5-$ to $10-\mathrm{cm}$ (data not shown; $\left.\mathrm{P}<0.005 ; \mathrm{r}^{2}=0.625\right)$ depths. In contrast, at lower depths, we found no significant increases with $\mathrm{CO}_{2}$ (Fig. 1a). As a result, $\mathrm{CO}_{2}$ concentration and soil depth interacted significantly on root biomass $\left(\mathrm{F}_{15}\right.$, $\left.{ }_{24}=5.450 ; \mathrm{P}<0.0001\right)$, indicating an overall shift in rooting depth upward. Total carbon sequestered in roots from the uppermost soil layer $(0-$ to $5-\mathrm{cm})$ increased 6-fold with elevated $\mathrm{CO}_{2}$ (Fig. 1b; $\left.\mathrm{P}<0.035 ; \mathrm{r}^{2}=0.372\right)$, even though $\% \mathrm{C}$ in root tissue did not vary 
significantly (data not shown). Root diameters declined significantly with increasing $\mathrm{CO}_{2}$, from 0.53 - to $0.34-\mathrm{mm}$ in the 250 - and 750-ppm treatments, respectively (Fig. 2; $\mathrm{P}$ $\left.<0.027 ; \mathrm{r}^{2}=0.401\right)$, although intra- and inter-chamber variation was high in the lower treatments.

\section{Carbon dynamics in roots}

The increase in standing root biomass with $\mathrm{CO}_{2}$ could have been a result of increased accumulation of new roots or decreased disappearance of old roots. Because recently produced "new" roots had a lower ${ }^{13} \mathrm{C}$-content than "old" roots present before $\mathrm{CO}_{2}$ manipulation, we were able to tease apart these effects in the top 5-cm of soil. The original ${ }^{13} \mathrm{C}$ signature of roots (before onset of the experiment) was indicated by the $\mathrm{d}^{13} \mathrm{C}$ of live roots collected outside the chambers (Fig. $3 ;-26.9 \% \circ \pm 1.2 \%$ o SE); roots in the chambers that had been constructed before $\mathrm{CO}_{2}$ manipulation began should have had that approximate signature. Live roots collected from the chambers were significantly more depleted in ${ }^{13} \mathrm{C}$ (Fig. $3 ;-31.7 \% \circ \pm 0.8 \%$; $\mathrm{P}<0.001$ ). Bulk (live + dead) roots from the chambers had intermediate signatures (Fig. $3 ;-30.6 \% \pm \pm 0.8 \%$ ) that were significantly different from roots representing original signatures $(\mathrm{P}<0.001)$ but not significantly different from live roots in the chambers. In addition, ${ }^{13} \mathrm{C}$ contents of live roots from the chambers decreased significantly with $\mathrm{CO}_{2}$ concentration (Fig. $3 ; \mathrm{P}<0.043 ; \mathrm{r}^{2}=0.380$ ) while bulk roots did not.

Based on the ${ }^{13} \mathrm{C}$ signatures of roots from the top 5-cm of soil, we calculate that across treatments, $80.2 \% \pm 11.7 \% \mathrm{SE}$ of carbon in bulk roots had been fixed since the onset of the experiment. The percentage of "new" carbon in bulk roots did not change 
significantly with treatment (Fig. 4). Four chambers displayed proportions of new $\mathrm{C}$ that were greater than $100 \%$; this result occurred wherever live roots where more ${ }^{13} \mathrm{C}$-enriched than bulk roots from the same chamber due to the relatively high degree of variability in signatures. Because the pool of $\mathrm{C}$ in bulk roots increased with elevated $\mathrm{CO}_{2}$ (Fig. 1b), total amounts of "new" root C (on a per meter basis) increased significantly as well (Fig. 5a; $\left.\mathrm{P}<0.012 ; \mathrm{r}^{2}=0.482\right)$. In contrast, total amounts of "old" $\mathrm{C}$ in roots were significantly higher in the intermediate-level $\mathrm{CO}_{2}$ treatments, with a best-fit non-linear regression of OldC $=31 \cdot e^{-0.5 \cdot\left(\frac{\mathrm{CO}_{2}-509}{58}\right)^{2}}\left(\right.$ Fig. $\left.5 \mathrm{~b} ; \mathrm{P}<0.022 ; \mathrm{r}^{2}=0.574\right)$.

\section{Discussion}

In this chaparral ecosystem, elevated $\mathrm{CO}_{2}$ increased bulk root biomass in upper soil layers (Fig. 1a,b), and the factors underlying this increase appeared to vary with $\mathrm{CO}_{2}$ level. Based on root signatures of ${ }^{13} \mathrm{C}$, a greater accumulation of "new" root $\mathrm{C}$ in the highest (750-pm) treatment (Fig. 5a) seemed to contribute to relatively high bulk root carbon there, potentially due to increased production of roots constructed after initiation of the experiment ("new" roots) or reduced turnover of new roots. In contrast, a relatively high accumulation of "old" $\mathrm{C}$ in roots appeared to raise bulk root carbon in the intermediate (450- and 550-ppm) $\mathrm{CO}_{2}$ treatments (Fig. 5b). Decomposition of roots constructed prior to onset of $\mathrm{CO}_{2}$ manipulation ("old" roots) may be slowed in those treatments. Alternately, old roots may have longer lifespans under these conditions. While stable isotopes are helpful in determining relative patterns of these processes across treatments, the absolute amounts of new or old root $\mathrm{C}$ derived from this approach 
should be interpreted with caution for several reasons. First, $\mathrm{d}^{13} \mathrm{C}$ signatures of bulk and live roots, as well as roots from outside the experimental chambers, were highly variable (Fig. 3) and even differed in live roots by as much as 6.4\% between the two 750-ppm chambers. This variation reduces the precision of our estimates accordingly. Second, live roots from the chambers may have included roots produced before the onset of $\mathrm{CO}_{2}$ manipulation. If so, we overestimate allocation of new $\mathrm{C}$ to bulk roots. The degree of this error would depend on the longevity of fine Adenostoma roots, which is unknown. If fine roots turn over within months to a few years, error is likely to be small. However, if they tend to live longer 3.5 years (the length of $\mathrm{CO}_{2}$ enrichment before sampling), we may have significantly overestimated the absolute amount of new $\mathrm{C}$ in standing roots. Likewise, if plants allocated stored old C to newly-produced roots, we would also have overestimated amounts of new C. Gaudinski et al. (2000) found that roots in a mixed deciduous forest in central Massachusetts received only recently-fixed $\mathrm{C}$, but $\mathrm{C}$ dynamics in chaparral may not be comparable. For these reasons, we use ${ }^{13} \mathrm{C}$ signatures only to indicate the relative importance of production and turnover across $\mathrm{CO}_{2}$ treatments, and not necessarily as an estimate of flux rates or pool sizes (Ehleringer et al. 2000). Why would root production or longevity increase under elevated $\mathrm{CO}_{2}$ in chaparral, as indicated by ${ }^{13} \mathrm{C}$ signatures of roots? As is thought to occur in other systems, an increase in water use efficiency conferred by $\mathrm{CO}_{2}$ enrichment may have ameliorated water limitation and extended the growing season in this water-stressed environment (Arnone et al. 2000; Bazzaz 1990; Berntson and Woodward 1992); augmentation of below- and above-ground productivity—or increased investment in root maintenance-is a possible 
result. In addition, a higher demand for nutrients following increased growth may have contributed to this effect. The observed enhancement of root biomass is consistent with the findings of the majority of $\mathrm{CO}_{2}$ studies, although the magnitude of the increase (7fold) in our study is much greater than usual. For example, reviews of $\mathrm{CO}_{2}$ studies report increases as high as $58 \%$ in native grasslands (Arnone et al. 2000) and 200-300\% in agricultural systems (Rogers et al. 1992; Rogers et al. 1994). The relatively large $\mathrm{CO}_{2}$ effect in chaparral may be attributable to the arid nature of this environment. Potential reasons for the increase in amounts of old $\mathrm{C}$ at intermediate $\mathrm{CO}_{2}$ concentrations are not straightforward (Fig. 5b). In this system, we have found that mycorrhizal abundance is highest at intermediate levels, and then declines at 750-ppm (K. Treseder, unpublished data). The presence of these fungi may have influenced root longevity, although it is not clear why old roots and not new roots would be affected. Alternately, the composition of the general community of soil microbes may have shifted under the $\mathrm{CO}_{2}$ gradient such that decomposers may have become less effective at 450- and 550ppm. We know of no other study that has examined the fate of old $\mathrm{C}$ at intermediate $\mathrm{CO}_{2}$ levels.

We observed a shift in distribution of roots upward (Fig. 1a); this result has also been found in crops (Chaudhuri et al. 1990; Prior et al. 1994; Pritchard and Rogers 2000), natural grasslands (Arnone et al. 2000), and forests (Larigauderie et al. 1988). However, we expected that rooting depth would increase in the chaparral so that plants could tap water in deeper horizons; soil in this site is dry and powdery at the surface for most of the year. Instead, plants may have increased foraging capacity for nutrients in the upper 
layers in response to increased nutrient demand. There was also a shift in root morphology toward finer roots (Fig. 2) that tend to be more efficient at procuring nutrients from the soil. A decrease in root diameter has been observed in other systems (Norby 1994; Tingey et al. 2000).

Since turnover rates of C can vary with soil depth due to changes in temperature and moisture, and decomposition rates of roots may increase as diameter decreases, these shifts in root architecture could have implications for carbon dynamics in the soil. Namely, the flux of $\mathrm{C}$ through roots may increase. Coupled with the increase in pool size of $\mathrm{C}$ in standing root biomass via greater accumulation of new $\mathrm{C}$ and decreased removal of old $\mathrm{C}$, elevated $\mathrm{CO}_{2}$ may have a marked effect on contribution of roots to soil $\mathrm{C}$ dynamics in chaparral. We suggest that other natural, water-stressed systems may have strong responses to $\mathrm{CO}_{2}$ enrichment and merit closer examination, especially to improve our understanding of large-scale C cycling under global change. 


\section{Literature cited}

Allen AS, Andrews JA, Finzi AC, Matamala R, Richter DD, Schlesinger WH (2000) Effects of free-air CO2 enrichment (FACE) on belowground processes in a Pinus taeda forest. Ecological Applications 10:437-448

Arnone JA, Zaller JG, Spehn EM, Niklaus PA, Wells CE, Korner C (2000) Dynamics of root systems in native grasslands: effects of elevated atmospheric $\mathrm{CO} 2$. New Phytologist 147:73-86

Bazzaz FA (1990) The response of natural ecosystems to the rising global $\mathrm{CO}_{2}$ levels. Annual Review of Ecology and Systematics 21:167-196

Berntson GM, Bazzaz FA (1996) Belowground positive and negative feedbacks on CO2 growth enhancement. Plant and Soil 187:119-131

Berntson GM, Woodward FI (1992) The Root-System Architecture and Development of Senecio-Vulgaris in Elevated Co2 and Drought. Functional Ecology 6:324-333

Chaudhuri UN, Burnett RB, Kirkham MB, Kanemasu ET (1986) Effect of CarbonDioxide on Sorghum Yield ; Root-Growth ; and Water-Use. Agricultural and Forest Meteorology 37:109-122

Chaudhuri UN, Kirkham MB, Kanemasu ET (1990) Root-Growth of Winter-Wheat under Elevated Carbon-Dioxide and Drought. Crop Science 30:853-857

Ehleringer JR, Buchmann N, Flanagan LB (2000) Carbon isotope ratios in belowground carbon cycle processes. Ecological Applications 10:412-422

Ehleringer JR, Osmond CB (1991) Stable isotopes. In: Pearcy RW, Ehleringer J, Mooney HA, Rundel PW (eds) Plant Physiological Ecology: Field Methods and Instrumentation. Chapman and Hall, London, pp 281-300

Gaudinski JB, Trumbore SE, Davidson EA, Zheng SH (2000) Soil carbon cycling in a temperate forest: radiocarbon-based estimates of residence times, sequestration rates and partitioning of fluxes. Biogeochemistry 51:33-69

Hungate BA, Jackson RB, Field CB, Chapin FS (1996) Detecting changes in soil carbon in $\mathrm{CO} 2$ enrichment experiments. Plant and Soil 187:135-145

Johnson MG, Phillips DL, Tingey DT, Storm MJ (2000) Effects of elevated CO2 ; Nfertilization ; and season on survival of ponderosa pine fine roots. Canadian Journal of Forest Research-Revue Canadienne De Recherche Forestiere 30:220-228

Larigauderie A, Hilbert DW, Oechel WC (1988) Effect of $\mathrm{CO}_{2}$ enrichment and nitrogen availabilty on resource acquisition and resource allocation in a grass, Bromus mollis. Oecologia 77:544-549

Nitschelm JJ, Luscher A, Hartwig UA, Vankessel C (1997) Using stable isotopes to determine soil carbon input differences under ambient and elevated atmospheric $\mathrm{CO} 2$ conditions. Global Change Biology 3:411-416

Norby RJ (1994) Issues and perspectives for investigating root responses to elevated atmospheric carbon dioxide. Plant and Soil 165:9-20 
Oechel WC, Riechers G, Lawrence WT, Prudhomme TJ, Grulke N, Hastings SJ (1992) $\mathrm{CO}_{2} \mathrm{LT}$ an automated, null-balance system for studying the effects of elevated $\mathrm{CO}_{2}$ and global climate change on unmanaged ecosystems. Functional Ecology 6:86-100

Pregitzer KS, Zak DR, Curtis PS, Kubiske ME, Teeri JA, Vogel CS (1995) Atmospheric CO-2, soil nitrogen and turnover of fine roots. New Phytologist 129:579-585

Pregitzer KS, Zak DR, Maziasz J, DeForest J, Curtis PS, Lussenhop J (2000) Interactive effects of atmospheric $\mathrm{CO} 2$ and soil-N availability on fine roots of Populus tremuloides. Ecological Applications 10:18-33.

Prior SA, Rogers HH, Runion GB, Hendrey GR (1994) Free-Air Co2 Enrichment of Cotton : Vertical and Lateral Root Distribution Patterns. Plant and Soil 165:33-44

Pritchard SG, Rogers HH (2000) Spatial and temporal deployment of crop roots in CO2enriched environments. New Phytologist 147:55-71

Roberts SW, Oechel WC, Bryant PJ, Hastings SJ, Major J, Nosov V (1998) A field fumigation system for elevated carbon dioxide exposure in chaparral shrubs. Functional Ecology 12:708-719

Rogers HH, Prior SA, O'Neill EG (1992) Cotton roots and rhizosphere responses to freeair CO2 enrichment. Critical Reviews of Plant Science 11:251-263

Rogers HH, Runion GB, Krupa SV (1994) Plant responses to atmospheric CO2 enrichment with emphasis on roots and the rhizosphere. Environmental Pollution 83:155-189

SPSS (2000a) SigmaPlot 2000. Version 6.10. Chicago

SPSS (2000b) Systat 10. Chicago

Thomas SM, Whitehead D, Reid JB, Cook FJ, Adams JA, Leckie AC (1999) Growth ; loss ; and vertical distribution of Pinus radiata fine roots growing at ambient and elevated CO2 concentration. Global Change Biology 5:107-121

Tingey DT, Johnson MG, Phillips DL, Storm MJ (1995) Effects of elevated CO2 and nitrogen on Ponderosa pine fine roots and associated fungal components. Journal of Biogeography 22:281-287

Tingey DT, Phillips DL, Johnson MG (2000) Elevated CO2 and conifer roots: effects on growth ; life span and turnover. New Phytologist 147:87-103

Van Kessel C, Horwath WR, Hartwig U, Harris D, Luscher A (2000a) Net soil carbon input under ambient and elevated $\mathrm{CO} 2$ concentrations: isotopic evidence after 4 years. Global Change Biology 6:435-444

Van Kessel C et al. (2000b) Carbon-13 input and turn-over in a pasture soil exposed to long-term elevated atmospheric CO2. Global Change Biology 6:123-135

Verburg PSJ, Gorissen A, Arp WJ (1998) Carbon Allocation and Decomposition of RootDerived Organic-Matter in a Plant-Soil System of Calluna-Vulgaris As Affected By Elevated Co2. Soil Biology \& Biochemistry 30:1251-1258 


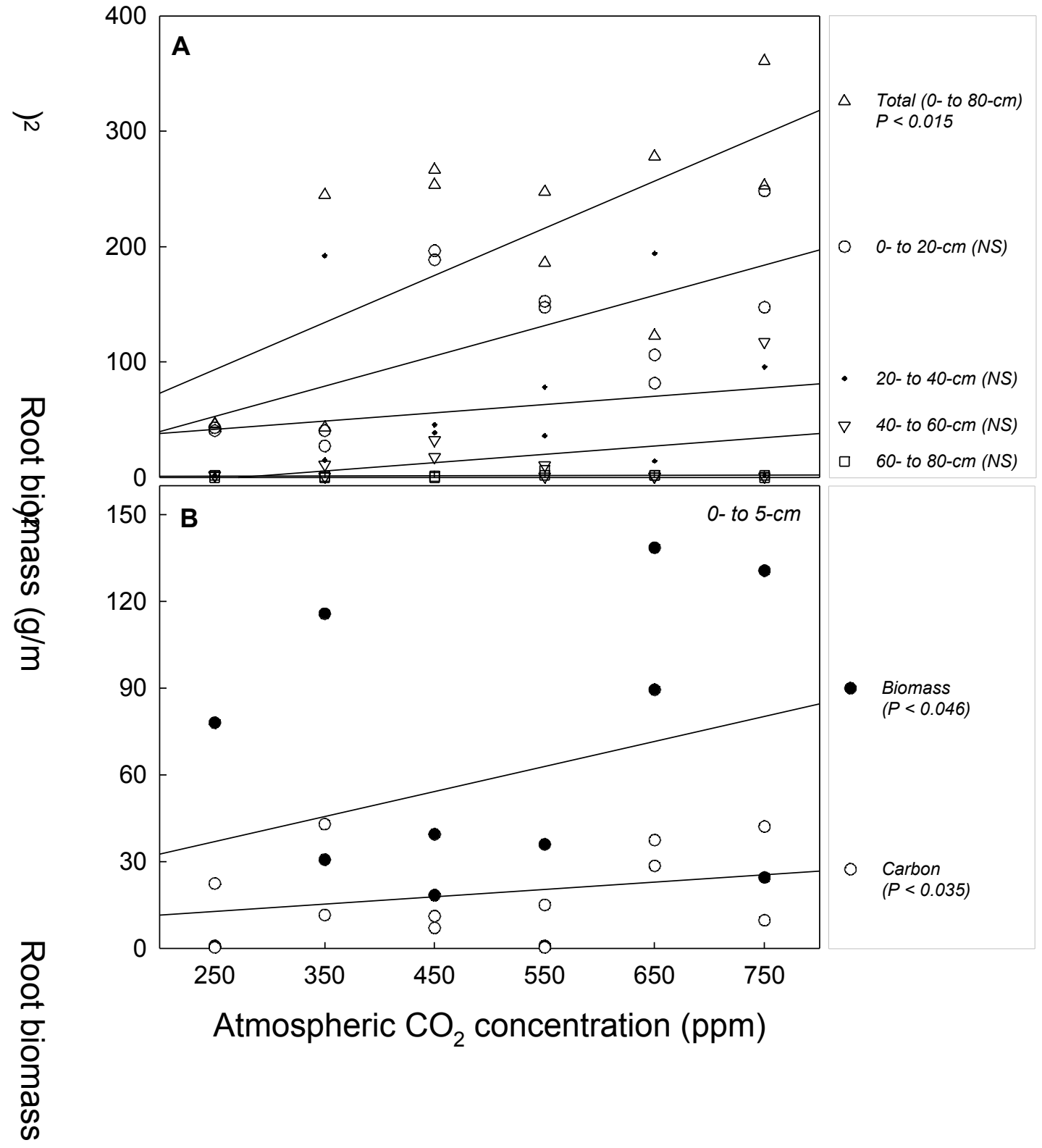

을 $\cong$ and (b) the top 5-cm of soil. Each symbol represents one chamber; lines indicate best fit Oํ.

긍

$\frac{\widehat{Q}}{3}$ 


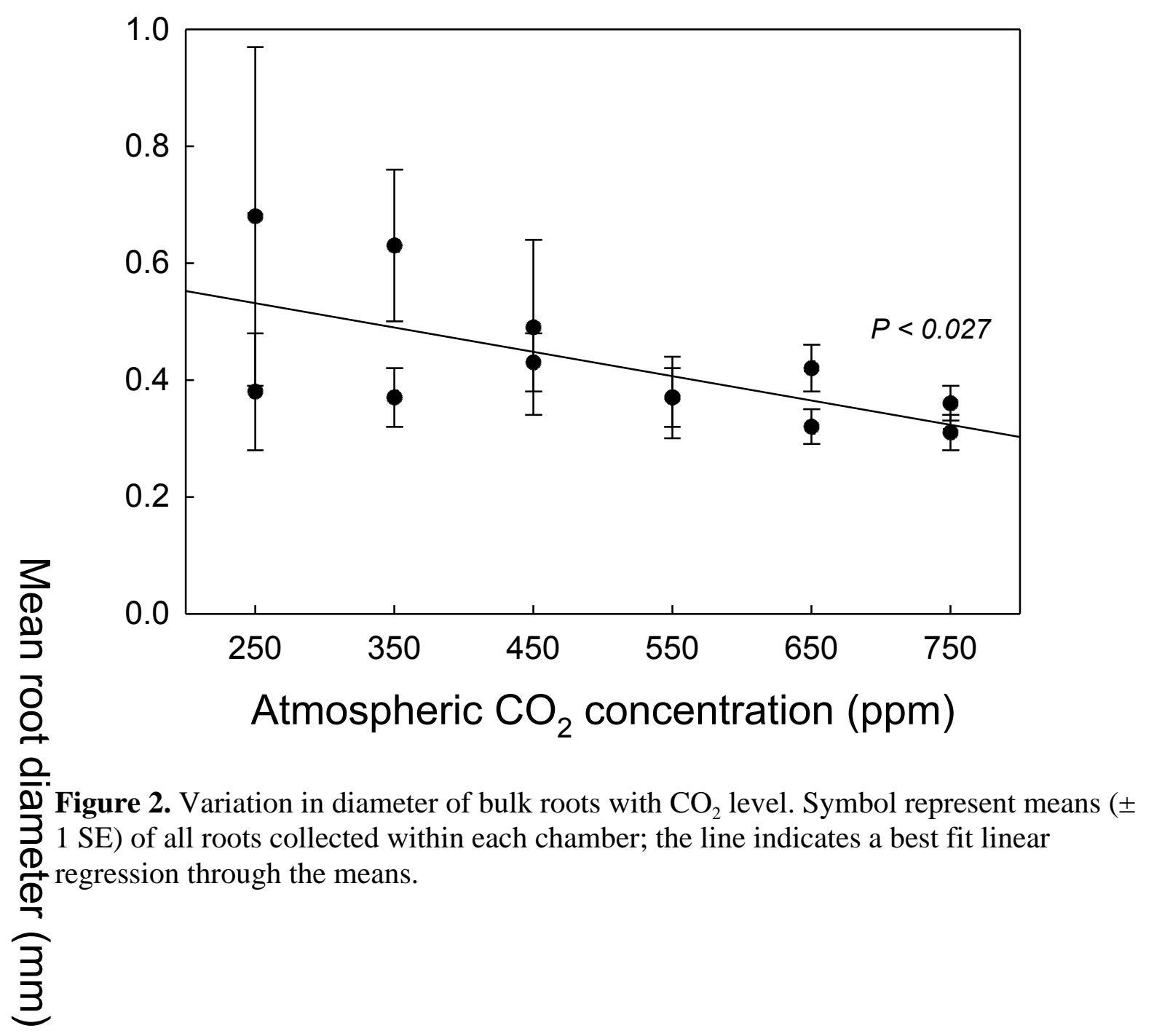




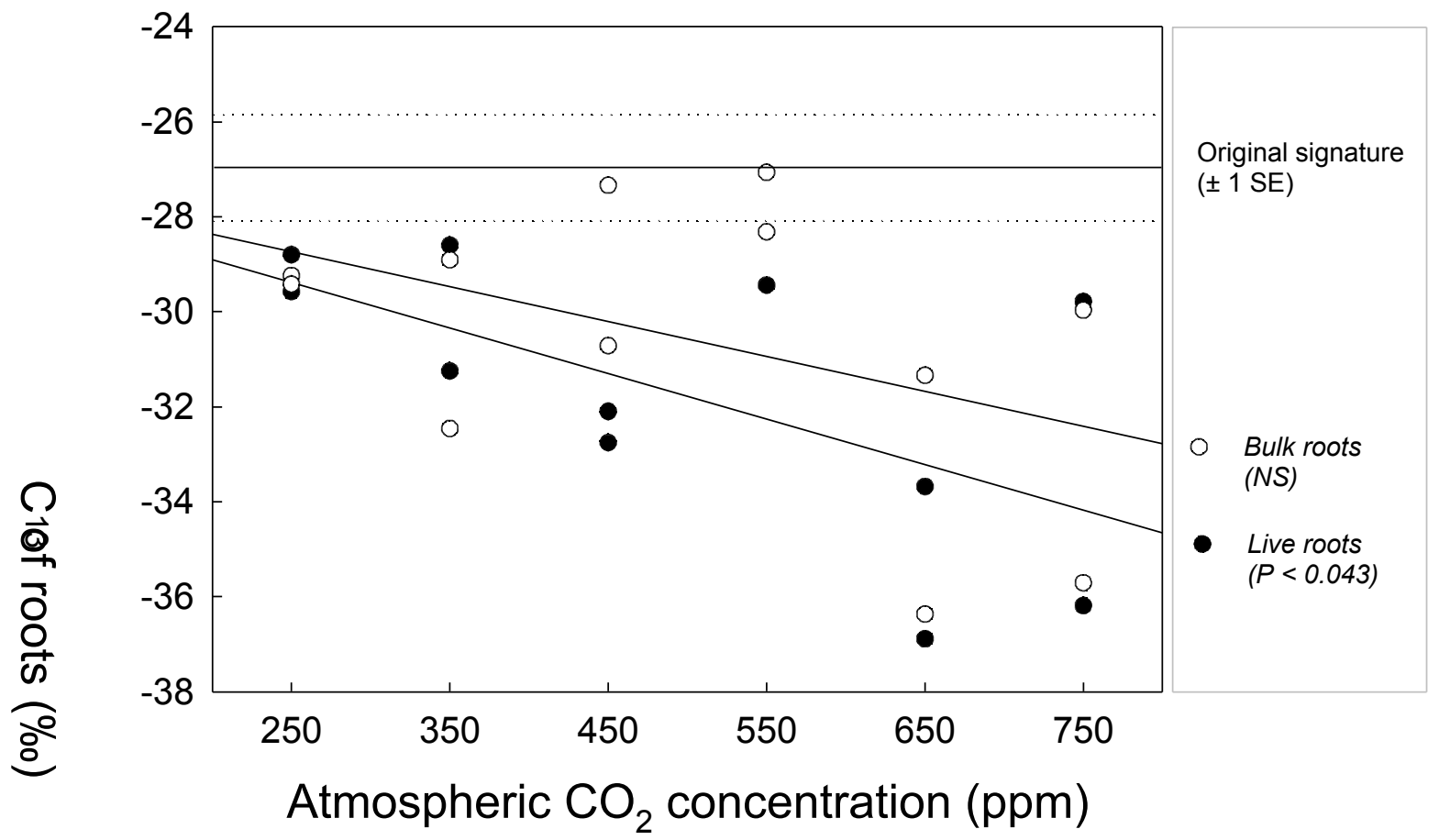

Figure 3. $\mathrm{d}^{13} \mathrm{C}$ signatures of roots from the top 5-cm of soil. Bulk roots (O) represent all roots (live and dead) in chambers. Live roots ( ) indicate the signature of recently-fixed $\mathrm{C}$ in the chambers. Each symbol represents one chamber. Best fit linear regressions through bulk and live roots are represented by lines, as is the ${ }^{13} \mathrm{C}$ content $( \pm 1 \mathrm{SE})$ of roots collected outside the chambers (representing the "original signature" of roots before $\mathrm{CO}_{2}$ fumigation commenced). 


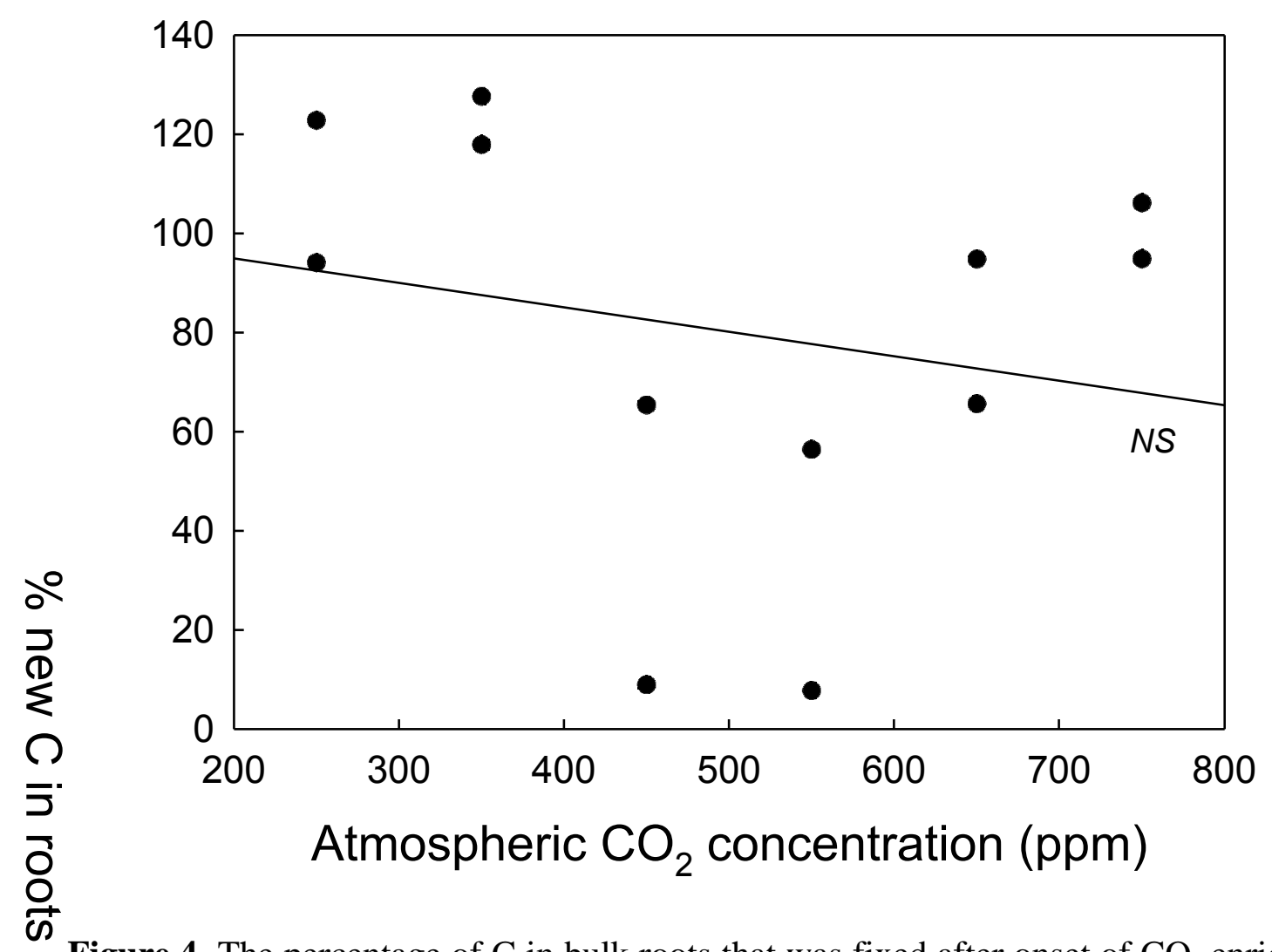

Figure 4. The percentage of $\mathrm{C}$ in bulk roots that was fixed after onset of $\mathrm{CO}_{2}$ enrichment ("new" C), calculated from ${ }^{13} \mathrm{C}$ signatures. Each symbol represents one chamber. The line indicates a best fit linear regression through all points. $\mathrm{NS}=$ no significant $\mathrm{CO}_{2}$ effect. 


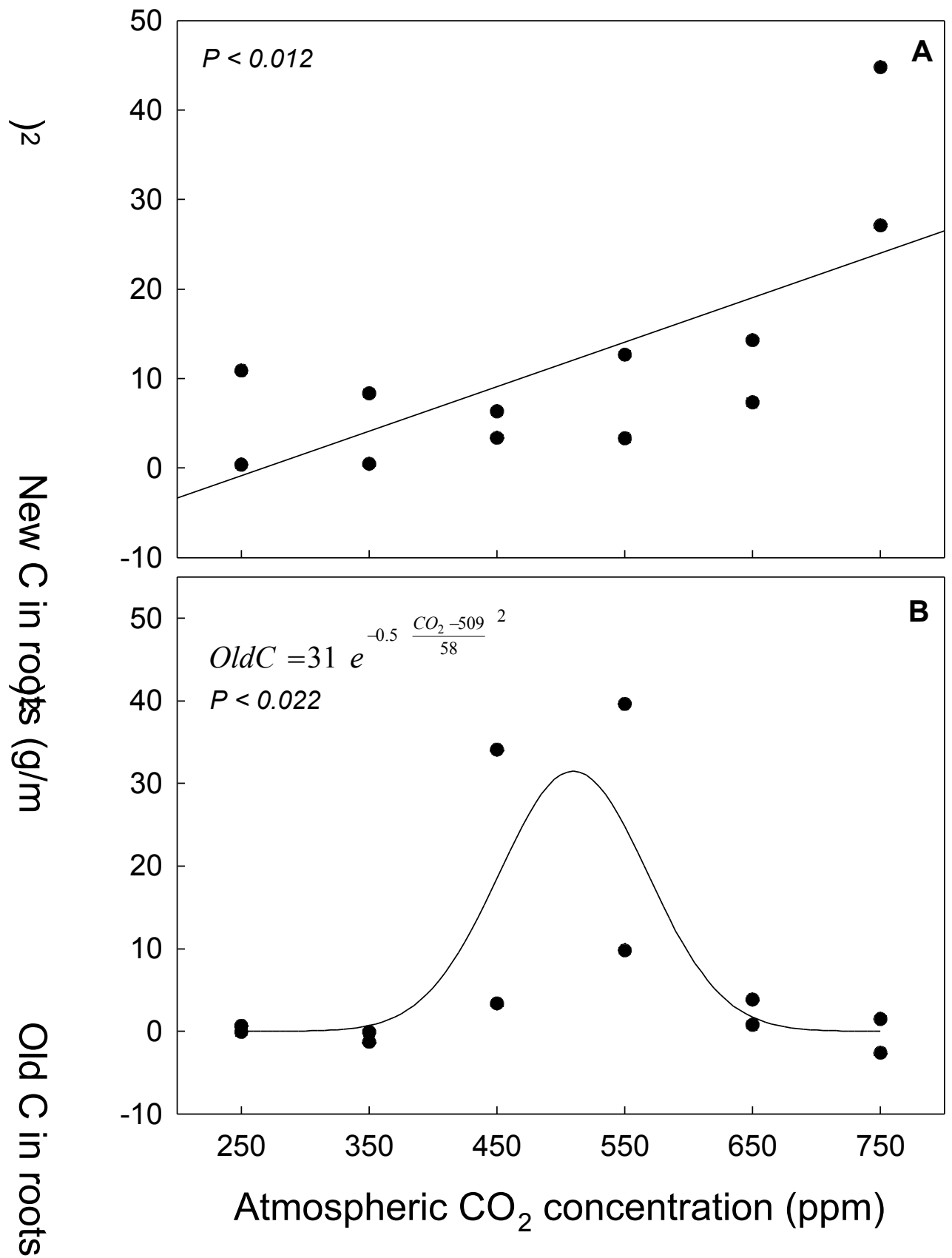

Q З ("new" C), and (b) before onset ("old" C). Each symbol represents one chamber. Lines indicate a best fit linear regression in (a) and non-linear regression in (b). 
Alteration of soil carbon by communities of mycorrhizal fungi in a chaparral ecosystem exposed to elevated $\mathrm{CO}_{2}$

\title{
Kathleen K. Treseder, Louise M. Egerton-Warburton, and Michael F. Allen
}

\section{Center for Conservation Biology, University of California,}

\section{Riverside, CA 92521 USA}

KEYWORDS: arbuscular mycorrhizal fungi, carbon stable isotopes, community composition, elevated $\mathrm{CO}_{2}$, macroaggregates, soil carbon sequestration

\begin{abstract}
We examined the potential of arbuscular mycorrhizal (AM) fungi to increase soil carbon storage under elevated atmospheric $\mathrm{CO}_{2}$. With antisera labeling, we assessed the community composition and total lengths of live AM hyphae associated with soil macroaggregates under varying $\mathrm{CO}_{2}$ levels. We then used stable isotopes to calculate $\mathrm{C}$ input to these macroaggregates. Carbon concentrations and AM hyphal lengths were correlated and rose 30-fold and 10-fold, respectively, with increasing $\mathrm{CO}_{2}$. The AM genera Scutellospora and Acaulospora responded strongly and positively to $\mathrm{CO}_{2}$ concentration, while Glomus and Gigaspora did not. AM fungi appear to increase macroaggregate- $\mathrm{C}$ under $\mathrm{CO}_{2}$ enrichment, possibly due to changes in community structure as well as stimulation of hyphal production. The $\mathrm{C}$ content of bulk soil may rise as macroaggregates disintegrate and release $\mathrm{C}$ into other soil fractions.
\end{abstract}




\section{Introduction}

Carbon allocation, sequestration, and turnover in terrestrial ecosystems remain critical issues in global carbon modeling and ecosystem science. In particular, changes in soil carbon dynamics under atmospheric $\mathrm{CO}_{2}$ enrichment are not well understood. The possibility that soils may partially sequester carbon emitted through fossil fuel burning and deforestation has been the subject of much recent attention and debate (e.g.

Schlesinger 1990; Hungate et al. 1996; Trumbore 1997; Batjes 1998; Schlesinger 1999). By focusing on the responses of various soil organisms to elevated $\mathrm{CO}_{2}$, we may gain a greater understanding of the mechanisms that may (or may not) produce this potential scenario.

In this paper, we address the influence of mycorrhizal fungi (microbes that symbiotically colonize plant roots) on soil $\mathrm{C}$ dynamics under $\mathrm{CO}_{2}$ enrichment. Numerous greenhouse and field chamber experiments have indicated that elevated atmospheric $\mathrm{CO}_{2}$ typically stimulates growth of mycorrhizal fungi (reviewed in Diaz 1996; Hodge 1996; Staddon and Fitter 1998; Cairney and Meharg 1999) with varying responses among genera (Klironomos et al. 1998). These fungi acquire all or most of their C directly from the host plant. Estimates of $\mathrm{C}$ allocation to mycorrhizal fungi range from 5 to $85 \%$ of net primary production, with 10 to $20 \%$ considered typical (Allen 1991). Arbuscular mycorrhizal (AM) fungi, in particular, are widespread. This group associates with over $80 \%$ of the world's plant species ranging from the tropics to the arctic and from deserts to rainforests (Smith and Read 1997). In addition, AM fungi are the sole producers of the 
glycoprotein glomalin (Wright and Upadhyaya 1996; Wright et al. 1996; Wright et al. 1998; Wright and Upadhyaya 1999), and their cell walls contain large portions of chitin and chitosan (Muzzarelli 1977). These compounds are relatively recalcitrant to decomposition and could be long-lived in the soil (Gooday 1994; Wright and Upadhyaya 1996). Thus, much of the $\mathrm{C}$ allocated to AM fungi may not be rapidly mineralized to $\mathrm{CO}_{2}$. To date, the capacity of mycorrhizal fungi to alter soil $\mathrm{C}$ content under elevated $\mathrm{CO}_{2}$ has been frequently suggested (e.g. Allen et al. 1995b; Rygiewicz et al. 1997; Staddon and Fitter 1998; Rillig et al. 1999b; Rillig and Allen 1999) but not directly examined. Mycorrhizal fungi also play a critical role in the formation of soil structure. Their hyphae bind together soil particles to form macroaggregates (1-2 mm diameter) which remain stable when wet (e.g. Tisdall and Oades 1979; Oades 1984; Miller and Jastrow 1990; Oades and Waters 1991; Jastrow et al. 1998). After hyphae deteriorate, residual glomalin may maintain these connections (Wright et al. 1998; Rillig et al. 1999b). Macroaggregate-rich soils tend to be resistant to wind and soil erosion (Emerson 1977; Lyles et al. 1983). In addition, because the organic material within these clusters is physically protected from microorganisms and external chemical processes, macroaggregates often differ from bulk soil in $\mathrm{C}$ turnover times and concentrations of organic C (Tisdall and Oades 1982; Jastrow 1996; Jastrow et al. 1996). A recent study has reported that macroaggregates are more prevalent under elevated $\mathrm{CO}_{2}$ in two Californian ecosystems, most likely due to an increase in the mass of mycorrhizal glomalin (Rillig et al. 1999b). 
In this study, we consider the role of AM community composition and biomass in soil carbon storage under elevated $\mathrm{CO}_{2}$. We evaluated the abundance and composition of AM hyphae occupying the macroaggregates and bulk soil from a chaparral ecosystem exposed to $\mathrm{CO}_{2}$ levels ranging from 250- to 750-ppm. Stable isotope techniques were then used to link $\mathrm{AM}$ hyphal biomass to rates of $\mathrm{C}$ input with increasing $\mathrm{CO}_{2}$. These data were used to test the hypotheses that $\mathrm{CO}_{2}$ enrichment (1) alters the amount of incorporated mycorrhizal biomass (and hence $\mathrm{C}$ allocation) within macroaggregates, and (2) modifies the AM community profile, and (3) in turn, such changes contribute to increased soil $\mathrm{C}$ storage with elevated $\mathrm{CO}_{2}$. 


\section{Materials and methods}

\section{Site}

The Sky Oaks $\mathrm{CO}_{2}$ enrichment study (operated by San Diego State University) is located near Temecula, California in chaparral vegetation dominated by Adenostoma fasciculatum (chemise) shrubs. Twelve closed 2- x 2-x 2-m chambers are each centered around individual Adenostoma and surrounding herbaceous plants. Atmospheric $\mathrm{CO}_{2}$ concentrations within the chambers are maintained at levels ranging from 250- to 750ppm in 100-ppm increments $(\mathrm{n}=2)$. The chambers are naturally lit (about $93 \%$ of ambient), and temperature is maintained at ambient levels (Oechel et al. 1992). Precipitation is collected from the chamber roof and channeled inside. In addition, a separate 10-m diameter free-air $\mathrm{CO}_{2}$ enrichment (FACE) ring maintains $\mathrm{CO}_{2}$ levels within the ring at 550-ppm. An undisturbed area slightly uphill from the FACE ring serves as a control (about 350-ppm). The site was burned in 1992, and $\mathrm{CO}_{2}$ enrichment started in December 1995.

\section{Sample collection and macroaggregate extraction}

In May 1999, we gathered about 2-g of full sun-exposed, green Adenostoma leaves from the four cardinal directions of each plant, and we compiled soil from four 5$\mathrm{cm}$ deep pits located at each cardinal direction within the canopy of those Adenostoma individuals. In June 1999, we collected leaf and soil samples from Adenostoma in the FACE ring and control area $(n=5)$. Soil was stored at $4^{\circ} \mathrm{C}$ for transport back to the laboratory, where particles greater than $2-\mathrm{mm}$ were sieved out and discarded. The 
remaining "bulk" soil was divided into three subsamples. For measurement of stable isotopes and $\mathrm{C}$ concentrations in bulk soil, one set of 5-g subsamples was oven-dried at $60^{\circ} \mathrm{C}$ for 72 hours. Leaves were also oven-dried for isotope analyses.

Within three hours of collection, water stable aggregates 1-2 mm in diameter were extracted from the second set of subsamples by wet-sieving as detailed in (Jastrow 1996). Fifty grams of soil were sieved through 1-mm mesh. Particles $>1$-mm diameter were slowly immersed in deionized water at $20^{\circ} \mathrm{C}$ and sieved for 20 -min through $1-\mathrm{mm}$ mesh while agitating at 30 cycles $\mathrm{min}^{-1}$. Aggregates that did not pass through the mesh were oven-dried at $60^{\circ} \mathrm{C}$ for $72 \mathrm{hrs,}$, weighed to determine macroaggregate mass, and used for stable isotope analysis. Macroaggregate extraction was performed on the third sample (also 50-g), except the macroaggregates were stored at $-20^{\circ} \mathrm{C}$ until used for immunofluorescence analysis of the mycorrhizal community.

\section{Stable isotope analyses and calculations}

To determine $\mathrm{d}^{13} \mathrm{C}$ and $\% \mathrm{C}$ of plant tissue and soil, oven-dried samples were ground to a fine mesh, enclosed in tin capsules, and run through a continuous flow mass spectrometer (Europa Integra, Stable Isotope Facility, University of California - Davis). $\mathrm{d}^{13} \mathrm{C}$ is calculated as $\left[\left({ }^{13} \mathrm{C} /{ }^{12} \mathrm{C}_{\text {sample }}\right) /\left({ }^{13} \mathrm{C} /{ }^{12} \mathrm{C}_{\text {standard }}\right)-1\right] \times 1000 \%$, where ${ }^{13} \mathrm{C} /{ }^{12} \mathrm{C}_{\text {sample }}$ and ${ }^{13} \mathrm{C} /{ }^{12} \mathrm{C}_{\text {standard }}$ are the isotope ratios of the sample and standard (PeeDee Belemnite), respectively (Ehleringer and Osmond 1991).

We used a mass balance equation to calculate the amount of new $\mathrm{C}$ in macroaggregates and bulk soil. The $\mathrm{d}^{13} \mathrm{C}$ signature of macroaggregate- $\mathrm{C}$ in each treatment can be represented as a linear equation in which the $\mathrm{d}^{13} \mathrm{C}$ of Adenostoma is used 
as the signature of the "new" $\mathrm{C}$ (fixed since onset of experiment) and the least-negative $\mathrm{d}^{13} \mathrm{C}$ of soil from the control area represents the "old" C (fixed before $\mathrm{CO}_{2}$ enrichment):

$$
\mathrm{d}^{13} \mathrm{C}_{\text {macro }}=\left[\left(\mathrm{d}^{13} \mathrm{C}_{\text {old }} * \% \text { old } \mathrm{C}\right)+\left(\mathrm{d}^{13} \mathrm{C}_{\text {new }} * \% \text { new } \mathrm{C}\right)\right] / 100,
$$

where $\mathrm{d}^{13} \mathrm{C}_{\text {macro }}$ is the signature of macroaggregate-C; $\mathrm{d}^{13} \mathrm{C}_{\text {old }}$, the isotopic composition of old C (-24.0\%o); $\mathrm{d}^{13} \mathrm{C}_{\text {new }}$, the signature of new $\mathrm{C}(-30.7$ to $-38.0 \%$ ); \%old $\mathrm{C}$, the proportion of $\mathrm{C}$ that is old; and \%new $\mathrm{C}$, the proportion of $\mathrm{C}$ that is new. The amount of new $\mathrm{C}$ is the product of \%new $\mathrm{C}$ and the total $\mathrm{C}$ concentration of the sample.

Concentrations of new $\mathrm{C}$ were not calculated for the FACE ring versus control, as new $\mathrm{C}$ had no distinct signature in the latter.

We then calculated the annual net $\mathrm{C}$ accumulation into macroaggregates by using estimates of percent new $\mathrm{C}$ and measurements of macroaggregate mass and \%C:

$$
\mathrm{C} \text { input }=\left(\% \text { macro/100) } *\left(\% \text { new } \mathrm{C}_{\text {macro }} / 100\right) *\left(\% \mathrm{C}_{\text {macro }} / 100\right) *\left(\text { density }_{\text {soi }}\right) / \mathrm{t},\right.
$$

where \%macro is the portion of bulk soil comprised of macroaggregates (by weight); $\%$ new $\mathrm{C}_{\text {macro }}$, the percentage of macroaggregate $\mathrm{C}$ that is new; $\% \mathrm{C}_{\text {macro }}$, the concentration of $\mathrm{C}$ in macroaggregates; $\mathrm{t}$, the time since onset of $\mathrm{CO}_{2}$ enrichment (3.5 years); and density $_{\text {soil }}$, soil bulk density $\left(1.35 \mathrm{~g} / \mathrm{cm}^{3}\right.$ for the upper $10-\mathrm{cm}$ of soil). Across treatments, about $5 \%$ of soil mass (by weight) was composed of macroaggregates. 


\section{Mycorrhizal measurements}

The percentage of macroaggregates and root fragments containing AM hyphae was determined by direct immunofluorescence. Antibodies were raised against each of the four major genera of AM fungi. Rabbits were immunized with whole spore fractions of Glomus deserticola Trappe, Bloss \& Menge, Acaulospora laevis (Nicol. \& Gerd.), Gigaspora margarita (Becker \& Hall), and Scutellospora calospora (Nicol. \& Gerd.) Walker and Sanders as described in (Egerton-Warburton and Allen 2000). Each antiserum was conjugated to fluoroscein isothiocyanate, and its specificity was determined by evaluating immunoreactivity between all combinations of antisera and spores of each species; no cross-reactions were detected (Allen et al. 1999). Duplicate samples of root fragments and entire macroaggregates from each $\mathrm{CO}_{2}$ concentration were incubated in diluted antisera (1:1 antisera: water) in the dark for $24 \mathrm{hr}$ at $20^{\circ} \mathrm{C}$, rinsed briefly in water and examined and scored under epifluorescence for the presence or absence of immunoreactive hyphae. Only live hyphae fluoresce under this stain (Friese and Allen 1991).

Macroaggregate-bound hyphae were dispersed by incubation in sodium hexametaphosphate solution $(39.5 \mathrm{~g} / \mathrm{L})$ for $1 \mathrm{hr}$ at $20^{\circ} \mathrm{C}$. For each sample, the extracted hyphae were collected, rinsed in deionized water, allocated to four subsamples and incubated in each of the antisera as described above. Incubated hyphae were collected by pulse centrifugation, rinsed briefly in deionized water, mounted on glass slides, and examined using epifluorescence (Egerton-Warburton and Allen 2000). All hyphae on the slides were measured and then designated as either immunoreactive (indicating the 
presence of a particular genus), or non-reactive hyphae. Non-reactive hyphae were further subdivided into AM or non-mycorrhizal hyphae on the basis of color and morphology under transmitted light and differential interference contrast optics. All immunolabeling and measurements were undertaken in duplicate.

\section{Statistics}

Relationships between $\mathrm{CO}_{2}$ treatment and either macroaggregate mass, $\mathrm{C}$ content, or mycorrhizal hyphal length were tested though linear regression analyses, and correlations between new C and hyphal length were examined using a Pearson test (SPSS 1998).

Changes in community composition of AM fungi were assessed with a Chi-square test. 


\section{Results}

\section{Mycorrhizal abundance and community composition}

We detected live AM hyphae on forty percent of macroaggregates. These hyphae could clearly be seen growing throughout the macroaggregates and intertwined with their component particles (Fig. 1c), as is often reported (e.g. Tisdall and Oades 1979; Oades 1984; Oades and Waters 1991). An additional fraction of macroaggregates was likely associated with dead hyphae that did not show a positive reaction to antisera (Fig. 1b). Fine roots can also form macroaggregates (Tisdall and Oades 1979; Oades 1984; Miller and Jastrow 1990; Oades and Waters 1991; Jastrow et al. 1998) and were assessed as another potential input of $\mathrm{C}$ into these particles. However, roots are sparse in these soils and were associated with only $2 \%$ of macroaggregates.

Hyphal biomass responded to $\mathrm{CO}_{2}$ concentration in both the chambers and the FACE ring. Lengths of AM fungal hyphae in macroaggregates rose more than ten-fold between the 250- and 650-ppm treatment, then sharply declined at 750-ppm (Fig. 2, linear regression with 750-ppm omitted, $\left.\mathrm{r}^{2}=0.635, \mathrm{P}<0.006\right)$. AM fungal biomass in macroaggregates was also greater in the FACE ring $(258-\mathrm{mm} / \mathrm{g})$ than in the control area $(90-\mathrm{mm} / \mathrm{g})$.

Shifts in community composition, as well as biomass, of AM fungi under elevated $\mathrm{CO}_{2}$ may indirectly affect soil $\mathrm{C}$ dynamics. We measured the abundance of four major genera of AM hyphae in macroaggregates from the closed chambers. Hyphal length among genera differed significantly in response to increasing $\mathrm{CO}_{2}$ (Fig. 3, $\mathrm{X}^{2}=55.77$, df 
$=15, \mathrm{P}<0.001)$. Scutellospora and Acaulospora were the rarest genera in the 250-ppm chambers, but their presence increased markedly with elevated $\mathrm{CO}_{2}$. In particular, hyphal length of Scutellospora increased 50-fold in response to $\mathrm{CO}_{2}$ treatment. In contrast, Glomus and Gigaspora had more subtle responses: Glomus predominated at low $\mathrm{CO}_{2}$ levels while the abundance of Gigaspora varied little across treatments. Comparable shifts in AM community composition were noted in the FACE rings (data not shown).

\section{Carbon dynamics}

We assessed soil $\mathrm{C}$ inputs in each $\mathrm{CO}_{2}$ treatment by using stable isotopes of $\mathrm{C}$ as tracers. The tank $\mathrm{CO}_{2}$ used to augment and stabilize $\mathrm{CO}_{2}$ levels in the Sky Oaks experiment is depleted in ${ }^{13} \mathrm{C}$ relative to the atmosphere $\left(\mathrm{d}^{13} \mathrm{C}\right.$ of tank $\mathrm{CO}_{2}$ : approximately $-29 \%$; atmospheric $\mathrm{CO}_{2}:-8 \%$ ). As a result, the $\mathrm{d}^{13} \mathrm{C}$ of tissue from Adenostoma declined significantly with greater $\mathrm{CO}_{2}$ concentrations (linear regression, $\mathrm{P}<0.012, \mathrm{r}^{2}=0.483$; $\mathrm{d}^{13} \mathrm{C}$ of Adenostoma $=-0.0093 *\left[\mathrm{ppm} \mathrm{CO}_{2}\right]-29.9 \%$ o). The $\mathrm{d}^{13} \mathrm{C}$ of mycorrhizal tissue reflects that of the host plant within reasonable limits ( 1.5\% ; Staddon et al. 1999), so hyphae should have signatures similar to those of Adenostoma.

We found that the $\mathrm{d}^{13} \mathrm{C}$ of macroaggregates decreased significantly with elevated $\mathrm{CO}_{2}$ in closed chambers $\left(\mathrm{P}<0.010, \mathrm{r}^{2}=0.497 ; \mathrm{d}^{13} \mathrm{C}=-0.0051 *\left[\mathrm{ppm} \mathrm{CO} \mathrm{CO}_{2}\right]-23.4 \%\right.$ ) and FACE plots (FACE ring $=-26.5 \%$, control $=-25.3 \%$ ), reflecting an incorporation of tank $\mathrm{CO}_{2}$ (via plants) into these particles. Bulk soil was depleted in ${ }^{13} \mathrm{C}$ relative to the control area, but did not vary among treatments (average: $-25.5 \%, \mathrm{P}>0.05, \mathrm{r}^{2}=0.054$ ). We used the difference between signatures of ${ }^{13} \mathrm{C}$-enriched "old" $\mathrm{C}$ and ${ }^{13} \mathrm{C}$-depleted "new" $\mathrm{C}$ to determine the proportion of macroaggregate- or bulk soil-C that had been fixed after the 
experiment started. We then calculated the amount of new $\mathrm{C}$ in macroaggregates or bulk soil.

Elevated $\mathrm{CO}_{2}$ affected $\mathrm{C}$ accumulation in macroaggregates but not in bulk soil. We found that concentrations of new $\mathrm{C}$ in macroaggregates varied almost 30 -fold among $\mathrm{CO}_{2}$ treatments (Fig 2). The mass of new $\mathrm{C}$ was near zero in the 250-ppm treatment but increased significantly with $\mathrm{CO}_{2}$ concentration $\left(\mathrm{P}<0.046, \mathrm{r}^{2}=0.342\right)$. In fact, the amount of new macroaggregate $\mathrm{C}$ at 350 - and $650-\mathrm{ppm}^{\mathrm{CO}} \mathrm{C}_{2}$ was equivalent to a net accumulation of 3 versus $14 \mathrm{~g} \mathrm{C} \mathrm{m}^{-2} \mathrm{yr}^{-1}$, respectively. The drop in new $\mathrm{C}$ at 750-ppm corresponds to low hyphal biomass in that treatment, and the abundance of new $\mathrm{C}$ was correlated with hyphal length across $\mathrm{CO}_{2}$ levels (Pearson correlation, $\mathrm{r}=0.574$, $\mathrm{df}=10, \mathrm{P}<0.06$ ). Total (old + new) $\mathrm{C}$ concentrations in macroaggregates increased with $\mathrm{CO}_{2}$ (linear regression, $\mathrm{P}$ $\left.<0.091, \mathrm{r}^{2}=0.259 ; \% \mathrm{C}=0.00219 *\left[\mathrm{ppm} \mathrm{CO} \mathrm{CO}_{2}\right]+0.632 \%\right)$. Atmospheric $\mathrm{CO}_{2}$ concentration did not significantly affect the amount of new C, total (old + new) C, or hyphae in bulk soil (linear regression; $\mathrm{P}>0.05 ; \mathrm{r}^{2}=0.012,0.042,0.060$, respectively). Finally, we found no significant effect of $\mathrm{CO}_{2}$ on the prevalence of macroaggregates (i.e. macroaggregate mass per unit bulk soil, linear regression, $\mathrm{P}>0.05, \mathrm{r}^{2}=0.260$ ). 


\section{Discussion}

Macroaggregates were commonly associated with mycorrhizal hyphae (Fig 1), but rarely with fine roots. Mycorrhizal fungi therefore appear to be the primary conduits of C into larger soil particles. We expect that the growth and decomposition of AM fungal tissue should influence the $\mathrm{C}$ content of macroaggregates. In particular, changes in mycorrhizal dynamics under elevated $\mathrm{CO}_{2}$ may alter $\mathrm{C}$ storage in this soil fraction.

Mycorrhizal growth responded strongly to elevated $\mathrm{CO}_{2}$. Hyphal length increased dramatically (by almost an order of magnitude) as $\mathrm{CO}_{2}$ levels approached 650-ppm, then declined sharply (Fig. 2). The drop in hyphal length at the highest $\mathrm{CO}_{2}$ treatment is puzzling, but very high levels of $\mathrm{CO}_{2}$ occasionally inhibit AM fungal growth (Becard and Piche 1989). This response may have occurred in the 750-ppm treatment, especially since soil $\mathrm{CO}_{2}$ concentrations typically exceed atmospheric levels. Many greenhouse- or growth chamber-based experiments have reported increases in mycorrhizal biomass under a doubling of $\mathrm{CO}_{2}$ concentration (reviewed in Diaz 1996; Hodge 1996; Staddon and Fitter 1998; Cairney and Meharg 1999). However, at this time, only one other published study has examined hyphal length in intact ecosystems exposed to long-term $\mathrm{CO}_{2}$. Rillig et al. (1999a) observed a nearly two-fold increase in hyphal length in a serpentine grassland (but no significant change in a sandstone grassland) after more than five years of $\mathrm{CO}_{2}$ enrichment. Other studies more than one year in length have also noted increases in the presence of ectomycorrhizal (Tingey et al. 1995) and AM (Klironomos et 
al. 1997) hyphae in open-top chambers with planted seedlings. None have directly examined the consequences of this biomass response for soil $\mathrm{C}$ dynamics.

We assessed the community composition, as well as the biomass, of AM fungi, since this factor could indirectly influence soil $\mathrm{C}$ inputs as well. Hyphal lengths of the four major $\mathrm{AM}$ genera shifted from a relatively even distribution at 250-ppm $\mathrm{CO}_{2}$ to dominance by Scutellospora and Acaulospora at 650-ppm (Fig. 3). Spore biomass among genera followed a comparable pattern in this $\mathrm{CO}_{2}$ experiment (S. Harney and M. F. Allen, unpublished data). Similarly, in a growth chamber study using single-species inoculations on potted plants, Klironomos and others (1998) demonstrated that hyphal lengths of Scutellospora calospora and Acaulospora denticulata increased significantly with elevated $\mathrm{CO}_{2}$, but those of two Glomus species did not. Our experiment is the first to document changes in the distribution of $\mathrm{AM}$ genera under elevated $\mathrm{CO}_{2}$ in a natural system.

The four genera of AM fungi may vary in life history characteristics and decomposability of hyphal tissue. For example, glomalin concentrations are lower in Glomus intraradices than in Gigaspora rosea (Wright and Upadhyaya 1999), which may lead to differences in decomposition rate. Similar variation may occur among the other AM genera and species (e.g. Acaulospora and Scutellospora). In addition, mycorrhizal genera and species differ in their ecological specificity and capacity to influence the growth and fitness of the host plant (e.g. Mosse 1972; Abbott and Robson 1981a; Abbott and Robson 1981b; Allen et al. 1995a). Shifts in mycorrhizal composition can therefore impact the structure, nutrient status, and productivity of the plant community (van der 
Heijden et al. 1998). Through these mechanisms, changes in community composition of $\mathrm{AM}$ fungi could feed back to alter $\mathrm{C}$ cycling under elevated $\mathrm{CO}_{2}$. Since $\mathrm{AM}$ community composition shifted and hyphal lengths increased in macroaggregates under elevated $\mathrm{CO}_{2}$, we expected that $\mathrm{C}$ inputs to this soil fraction would change as well. Alterations in soil $\mathrm{C}$ dynamics due to short-term $\mathrm{CO}_{2}$ enrichment are often difficult to measure because the pool of pre-existing $\mathrm{C}$ is usually large. However, by using stable isotope ratios $\left(\mathrm{d}^{13} \mathrm{C}\right)$ to focus only on $\mathrm{C}$ that has been fixed under $\mathrm{CO}_{2}$ enrichment, we could track the fate of that C (e.g. Hungate et al. 1996; Leavitt et al. 1996; Nitschelm et al. 1997; Lin et al. 1999). We calculated that $\mathrm{C}$ inputs to macroaggregates increased markedly (almost 30fold) between the 250 -and 650-ppm treatments, and were correlated with hyphal length (Fig. 2). These results indicate that an increase in growth of mycorrhizal hyphae under elevated $\mathrm{CO}_{2}$ may augment macroaggregate $\mathrm{C}$ pools.

This increase in gain of new $\mathrm{C}$ could be offset by a potential rise in decomposition rates with elevated $\mathrm{CO}_{2}$. However, total (old + new) $\mathrm{C}$ concentrations in macroaggregates rose under $\mathrm{CO}_{2}$ enrichment, indicating a net augmentation in $\mathrm{C}$ storage in these particles. Our results are consistent with measurements of net ecosystem flux (net primary productivity minus heterotrophic respiration) in the chambers. There appears to be a net ecosystem loss of $\mathrm{C}$ at lower $\mathrm{CO}_{2}$ levels, and a net gain where atmospheric $\mathrm{CO}_{2}$ exceeds 550-ppm (Y. Cheng, S. J. Hastings, W. Oechel, unpublished material).

The amount of new $\mathrm{C}$ in macroaggregates (Fig. 2) is probably not solely attributable to $\mathrm{C}$ contained in live hyphae. Rather, the rise in $\mathrm{C}$ input in macroaggregates under enriched $\mathrm{CO}_{2}$ might be due in part to an increase in the pool of residual organic $\mathrm{C}$ 
that remains after hyphae have decomposed. Chitin, a major constituent of fungal cell walls, is resistant to decomposition (Gooday 1994) and may be a long-lived pool of organic $\mathrm{C}$ in macroaggregates. In addition, microarthropods graze preferentially on nonmycorrhizal versus AM hyphae (Klironomos and Kendrick 1996), which may slow turnover rates. Rillig and others (1999b) found that concentrations of glomalin, another potentially recalcitrant component of AM tissue, significantly increased with $\mathrm{CO}_{2}$ level in Sky Oaks and other ecosystems.

This study by Rillig and colleagues (1999b) documented a significant increase in the abundance of smaller $(0.25-1.0 \mathrm{~mm}$ in diameter), but not larger $(1-2 \mathrm{~mm})$ macroaggregates. We also found no response in the prevalence of the latter size fraction. The main influence of increased hyphal growth in larger macroaggregates appears to be an augmentation of $\mathrm{C}$ concentrations within these particles. It has been suggested that $\mathrm{C}$ within macroaggregates may turn over more slowly than $\mathrm{C}$ in bulk soil because aggregates form a physical barrier to decomposer chemicals and organisms (Tisdall and Oades 1982; Jastrow 1996; Jastrow et al. 1996). Supporting evidence for this mechanism is not always straightforward (Jastrow et al. 1996), but physical protection could act as another feedback on $\mathrm{C}$ sequestration in macroaggregates.

This system had been exposed to elevated $\mathrm{CO}_{2}$ for 3.5 years at the time of sampling, so possibly only the more responsive fractions of soil (e.g. macroaggregates) were affected in this short time. Hungate and others (1996) found little response to elevated $\mathrm{CO}_{2}$ in soil organic $\mathrm{C}$ and $\mathrm{C}$ input after 2-3 years of $\mathrm{CO}_{2}$ enrichment in two 
California grasslands, although other studies have reported increases in C input (Ineson et al. 1996; Nitschelm et al. 1997) and soil C (e.g. Leavitt et al. 1994; Wood et al. 1994; Nitschelm et al. 1997) within that time. Another consideration in our study is that carbon in macroaggregates represents 2 to $5 \%$ of total soil $\mathrm{C}$ and is not likely to have an immediate influence on the $\mathrm{C}$ content of bulk soil. However, macroaggregates eventually break down into smaller particles as hyphae and fine roots decompose (Oades 1984). Through this process, $\mathrm{C}$ allocated to macroaggregates could enter other soil fractions and potentially raise $\mathrm{C}$ concentrations of bulk soil. Nevertheless, it remains to be seen whether these mycorrhizal responses represent long-term trends, or if hyphal growth and/or $\mathrm{C}$ in macroaggregates will reach steady-state levels within a relatively short time.

Overall, our results suggest that arbuscular mycorrhizal fungi influence the response of soil $\mathrm{C}$ dynamics to elevated atmospheric $\mathrm{CO}_{2}$ levels through changes in hyphal biomass. Shifts in fungal community composition may also have unforeseen consequences for carbon cycling. We note that effects on $\mathrm{C}$ input were limited to macroaggregates but may spread to other soil components with time. Since mycorrhizal fungi are widespread, and increases in mycorrhizal growth under elevated $\mathrm{CO}_{2}$ have been reported in many studies, this feedback could influence $\mathrm{C}$ cycling at the global level and potentially slow increases in atmospheric $\mathrm{CO}_{2}$ concentrations. Further study of mycorrhizal effects on soil dynamics (especially estimates of large-scale hyphal production and biomass under elevated $\mathrm{CO}_{2}$ ) could greatly facilitate our understanding of the importance of mycorrhizal fungi to the global $\mathrm{C}$ cycle. 


\section{Acknowledgements}

We thank R. Lepe, E. M. Olivares, D. Harris, Y. Cheng, W. C. Oechel, M. C. Rillig, and S. J. Hastings for technical help and input. We also thank San Diego State University for use of the Sky Oaks facility. Comments from W. H. Schlesinger and C. B. Field greatly improved this manuscript. This research was funded by an Ecosystems Research grant from the Department of Energy (\#DE-FG03-93ER61669) to M. F. A, and by an National Science Foundation Postdoctoral Fellowship (awarded in 1998) to K. K. T. Any opinions, findings, and conclusions or recommendations expressed in this publication are those of the authors and do not necessarily reflect the views of the National Science Foundation. 


\section{References}

Abbott LK, Robson AD (1981a) Infectivity and effectiveness of five endomycorrhizal fungi: competition with indigenous fungi in field soils. Australian Journal of Agricultural Research, 32, 621-630.

Abbott LK, Robson AD (1981b) Infectivity and effectiveness of vesicular arbuscular mycorrhizal fungi: effect of inoculum type. Australian Journal of Agricultural Research, 32, 631-639.

Allen EB, Allen MF, Helm DJ, Trappe JM, Molina R, Rincon E (1995a) Patterns and regulation of mycorrhizal plant and fungal diversity. Plant and Soil, 170, 47-62.

Allen MF (1991) The Ecology of mycorrhizae, Cambridge University Press, Cambridge, $184 \mathrm{pp}$.

Allen MF, Egerton-Warburton LM, Allen EB, Karen O (1999) Mycorrhizae in Adenostoma fasciculatum hook. \& arn.: a combination of unusual ecto- and endoforms. Mycorrhiza, 8, 225-228.

Allen MF, Morris SJ, Edwards F, Allen EB (1995b) Microbe-plant interactions in Mediterranean-type habitats: Shifts in fungal symbiotic and saprophytic functioning in response to global change. In Global change and Mediterraneantype ecosystems, Vol. 117 (Eds, Moreno JM, Oechel WC), pp. 297-305. SpringerVerlag, New York.

Batjes NH (1998) Mitigation of atmospheric $\mathrm{CO}_{2}$ concentrations by increased carbon sequestration in the soil. Biology and Fertility of Soils, 27, 230-235.

Becard G, Piche Y (1989) Fungal growth-stimulation by $\mathrm{CO}_{2}$ and root exudates in vesicular-arbuscular mycorrhizal symbiosis. Applied and Environmental Microbiology, 55, 2320-2325.

Cairney JWG, Meharg AA (1999) Influences of anthropogenic pollution on mycorrhizal fungal communities. Environmental Pollution, 106, 169-182.

Diaz S (1996) Effects of elevated $\left[\mathrm{CO}_{2}\right]$ at the community level mediated by root symbionts. Plant and Soil, 187, 309-320.

Egerton-Warburton LM, Allen EB (2000) Shifts in arbuscular mycorrhizal communities along an anthropogenic nitrogen deposition gradient. Ecological Applications, 10, in press.

Ehleringer JR, Osmond CB (1991) Stable isotopes. In Plant Physiological Ecology: Field Methods and Instrumentation (Eds, Pearcy RW, Ehleringer J, Mooney HA, Rundel PW), pp. 281-300. Chapman and Hall, London. 
Emerson WW (1977) Physical properties and structure. In Soil factors in crop production in a semi-arid environment (Eds, Russell JS, Greacen EL), pp. 78-104. University of Queensland Press, Queensland.

Friese CF, Allen MF (1991) Tracking the fates of exotic and local VA mycorrhizal fungi: methods and patterns. Agriculture Ecosystems \& Environment, 34, 87-96.

Gooday GW (1994) Physiology of microbial degradation of chitin and chitosan. In Biochemistry of Microbial Degradation (Ed, Ratledge C), pp. 279-312. Kluwer Academic, Netherlands.

Hodge A (1996) Impact of elevated $\mathrm{CO}_{2}$ on mycorrhizal associations and implications for plant growth. Biology and Fertility of Soils, 23, 388-398.

Hungate BA, Jackson RB, Field CB, Chapin FS (1996) Detecting changes in soil carbon in $\mathrm{CO} 2$ enrichment experiments. Plant and Soil, 187, 135-145.

Ineson P, Cotrufo MF, Bol R, Harkness DD, Blum H (1996) Quantification of soil carbon inputs under elevated $\mathrm{CO}_{2}: \mathrm{C}_{3}$ plants in a $\mathrm{C}_{4}$ soil. Plant and Soil, 187, 345-350.

Jastrow JD (1996) Soil aggregate formation and the accrual of particulate and mineralassociated organic matter. Soil Biology and Biochemistry, 28, 665-676.

Jastrow JD, Boutton TW, Miller RM (1996) Carbon dynamics of aggregate-associated organic matter estimated by carbon-13 natural abundance. Soil Science Society of America Journal, 60, 801-807.

Jastrow JD, Miller RM, Lussenhop J (1998) Contributions of interacting biological mechanisms to soil aggregate stabilization in restored prairie. Soil Biology and Biochemistry, 30, 905-916.

Klironomos JH, Ursic M, Rillig M, Allen MF (1998) Interspecific differences in the response of arbuscular mycorrhizal fungi to Artemisia tridentata grown under elevated $\mathrm{CO}_{2}$. New Phytologist, 138, 599-605.

Klironomos JN, Kendrick WB (1996) Palatability of microfungi to soil arthropods in relation to the functioning of arbuscular mycorrhizae. Biology and Fertility of Soils, 21, 43-52.

Klironomos JN, Rillig MC, Allen MF, Zak DR, Kubiske M, Pregitzer KS (1997) Soil fungal-arthropod responses to Populus tremuloides grown under enriched atmospheric CO2 under field conditions. Global Change Biology, 3, 473-478.

Leavitt SW, Paul EA, Galadima A, Nakayama FS, Danzer SR, Johnson H, Kimball BA (1996) Carbon isotopes and carbon turnover in cotton and wheat FACE experiments. Plant and Soil, 187, 147-155.

Leavitt SW, Paul EA, Kimball BA, et al. (1994) Carbon isotope dynamics of free-air $\mathrm{CO}_{2}$-enriched cotton and soils. Agricultural and Forest Meteorology, 70, 87-101. 
Lin GH, Ehleringer JR, Rygiewicz PT, Johnson MG, Tingey DT (1999) Elevated CO2 and temperature impacts on different components of soil $\mathrm{CO}_{2}$ efflux in Douglasfir terracosms. Global Change Biology, 5, 157-168.

Lyles LL, Hagen LJ, Skidmore EL (1983) Soil conservation: Principles of erosion by wind. In Dryland Agriculture (Eds, Dregne HE, Willis WW), pp. 177-188. American Society of Agronomy, Madison WI.

Miller RM, Jastrow JD (1990) Hierarchy of root and mycorrhizal fungal interactions with soil aggregation. Soil Biology and Biochemistry, 22, 579-584.

Mosse B (1972) Effects of different Endogone strains on the growth of Paspalum notatum. Nature, 239, 221.

Muzzarelli RAA (1977) Chitin, Pergamon, New York, 309pp.

Nitschelm JJ, Luscher A, Hartwig UA, Vankessel C (1997) Using stable isotopes to determine soil carbon input differences under ambient and elevated atmospheric $\mathrm{CO}_{2}$ conditions. Global Change Biology, 3, 411-416.

Oades JM (1984) Soil organic-matter and structural stability: mechanisms and implications for management. Plant and Soil, 76, 319-337.

Oades JM, Waters AG (1991) Aggregate hierarchy in soils. Australian Journal of Soil Research, 29, 815-828.

Oechel WC, Riechers G, Lawrence WT, Prudhomme TJ, Grulke N, Hastings SJ (1992) $\mathrm{CO}_{2} \mathrm{LT}$ : an automated, null-balance system for studying the effects of elevated $\mathrm{CO}_{2}$ and global climate change on unmanaged ecosystems. Functional Ecology, 6 , 86-100.

Rillig MC, Allen MF (1999) What is the role of arbuscular mycorrhizal fungi in plant-toecosystem responses to elevated atmospheric $\mathrm{CO}_{2}$ ? Mycorrhiza, 9, 1-8.

Rillig MC, Field CB, Allen MF (1999a) Soil biota responses to long-term atmospheric $\mathrm{CO}_{2}$ enrichment in two California annual grasslands. Oecologia (Berlin), 119, 572-577.

Rillig MC, Wright SF, Allen MF, Field CB (1999b) Long-term $\mathrm{CO}_{2}$ elevation affects soil structure of natural ecosystems. Nature, 400, 628.

Rygiewicz PT, Johnson MG, Ganio LM, Tingey DT, Storm MJ (1997) Lifetime and temporal occurrence of ectomycorrhizae on Ponderosa pine (Pinus ponderosa Laws) seedlings grown under varied atmospheric $\mathrm{CO}_{2}$ and nitrogen levels. Plant and Soil, 189, 275-287.

Schlesinger WH (1990) Evidence from chronosequence studies for a low carbon-storage potential of soils. Nature, 348, 232-234.

Schlesinger WH (1999) Carbon sequestration in soils. Science, 284, 2095.

Smith SE, Read DJ (1997) Mycorrhizal symbiosis, Academic Press, San Diego, 605. 
SPSS (1998) Systat 8.0. Chicago.

Staddon PL, Fitter AH (1998) Does elevated atmospheric carbon dioxide affect arbuscular mycorrhizas? Trends in Ecology \& Evolution, 13, 455-458.

Staddon PL, Robinson D, Graves JD, Fitter AH (1999) The $\mathrm{d}^{13} \mathrm{C}$ signature of the external phase of a Glomus mycorrhizal fungus: Determination and implications. Soil Biology \& Biochemistry, 31, 1067-1070.

Tingey DT, Johnson MG, Phillips DL, Storm MJ (1995) Effects of elevated $\mathrm{CO}_{2}$ and nitrogen on Ponderosa pine fine roots and associated fungal components. Journal of Biogeography, 22, 281-287.

Tisdall JM, Oades JM (1979) Stabilization of soil aggregates by the root systems of ryegrass. Australian Journal of Soil Research, 17, 429-441.

Tisdall JM, Oades JM (1982) Organic-matter and water-stable aggregates in soils. Journal of Soil Science, 33, 141-163.

Trumbore SE (1997) Potential responses of soil organic carbon to global environmental change. Proceedings of the National Academy of Sciences, 94, 8384-8291.

van der Heijden MGA, Klironomos JN, Ursic M, et al. (1998) Mycorrhizal fungal diversity determines plant biodiversity, ecosystem variability and productivity. Nature, 396, 69-72.

Wood CW, Torbert HA, Rogers HH, Runion GB, Prior SA (1994) Free-air $\mathrm{CO}_{2}$ enrichment effects on soil carbon and nitrogen. Agricultural and Forest Meteorology, 70, 103-116.

Wright SF, Franke-Snyder M, Morton JB, Upadhyaya A (1996) Time-course study and partial characterization of a protein on hyphae of arbuscular mycorrhizal fungi during active colonization of roots. Plant and Soil, 181, 193-203.

Wright SF, Upadhyaya A (1996) Extraction of an abundant and unusual protein from soil and comparison with hyphal protein of arbuscular mycorrhizal fungi. Soil Science, 161, 575-586.

Wright SF, Upadhyaya A (1999) Quantification of arbuscular mycorrhizal fungi activity by the glomalin concentration on hyphal traps. Mycorrhiza, 8, 283-285.

Wright SF, Upadhyaya A, Buyer JS (1998) Comparison of N-Linked oligosaccharides of glomalin from arbuscular mycorrhizal fungi and soils by capillaryelectrophoresis. Soil Biology \& Biochemistry, 30, 1853-1857. 


\section{Figure legends}

Figure 1. (Note: not shown). Confocal laser scanning microscope images illustrating a control macroaggregate in which arbuscular mycorrhizal (AM) hyphae are absent (a), and macroaggregates with non-immunoreactive AM hyphae bound to the surface (arrows) (b), and immunoreactive (fluorescent) hyphae of Acaulospora extending from a macroaggregate (arrows) (c).

Figure 2. Carbon input (lines) and hyphal length of arbuscular mycorrhizal fungi (columns) in 1-2 mm diameter macroaggregates under a range of atmospheric $\mathrm{CO}_{2}$ levels. Points and columns represent means $( \pm 1 \mathrm{SE})$ of two chambers. Hyphal length and $\mathrm{C}$ input varied significantly with treatment $(\mathrm{P}<0.006$ and 0.046 , respectively).

Figure 3. Hyphal length of four major genera of arbuscular mycorrhizal fungi in 1-2 mm diameter macroaggregates. Each point represents a mean of two chambers. Abundance of the genera changed significantly with $\mathrm{CO}_{2}$ concentration $(\mathrm{P}<0.0001)$ 


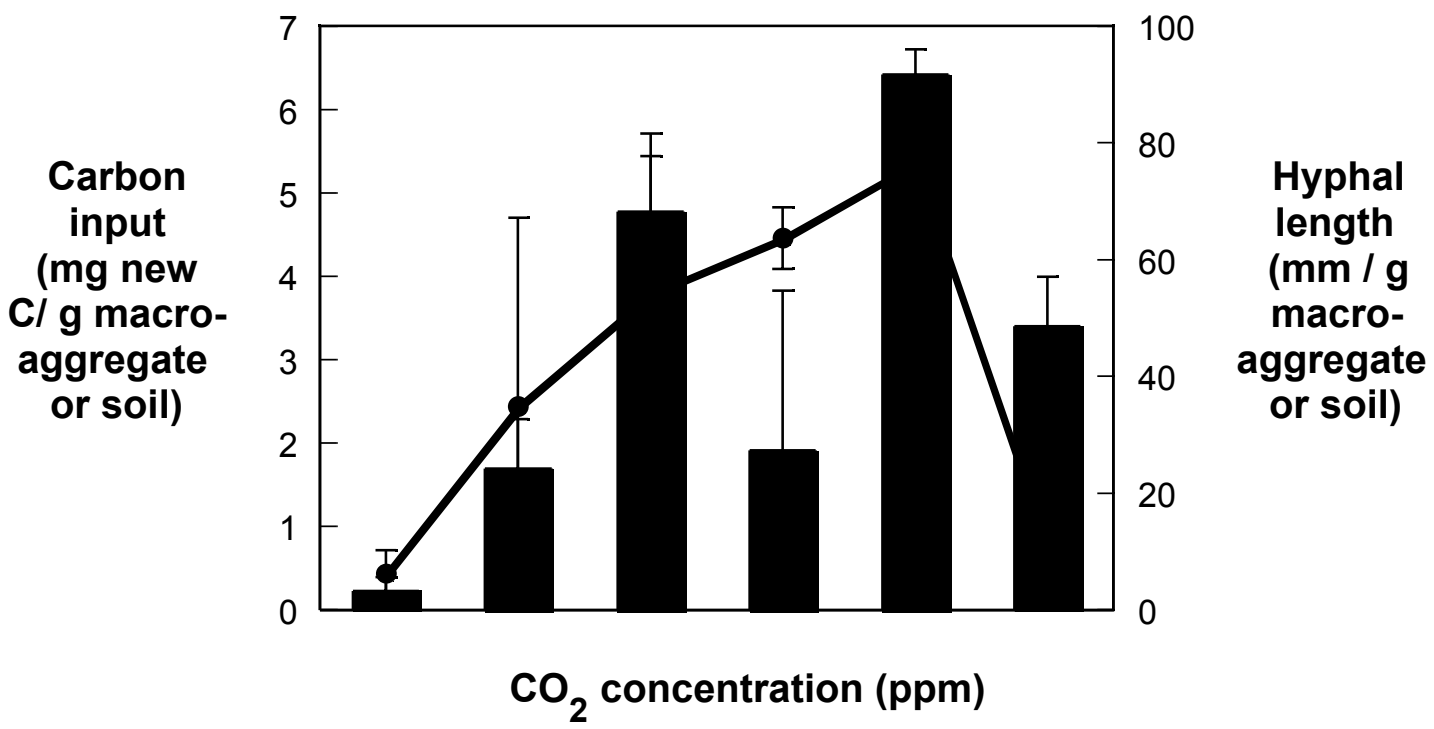




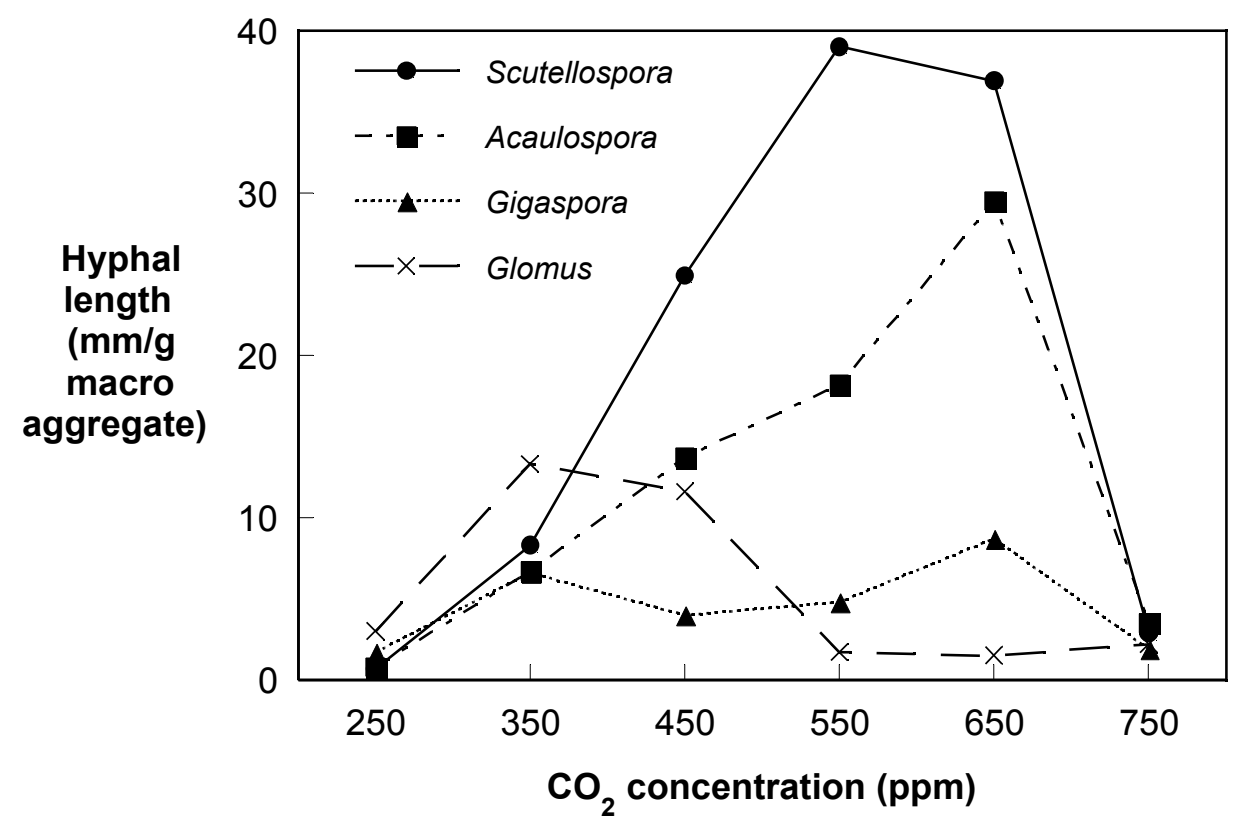




\title{
Effects of whole-ecosystem atmospheric carbon dioxide concentration manipulation on arthropod population dynamics in southern California chaparral.
}

\author{
Alison Eileen Williams

\section{Introduction} \\ Research indicates that increased atmospheric $\mathrm{CO}_{2}$ concentrations will \\ substantially alter the composition and function of Mediterranean-type ecosystems \\ (Oechel et al. 1995) and associated arthropod populations (Whittaker 1999). Prior to the \\ turn of the century and the industrial revolution, atmospheric $\mathrm{CO}_{2}$ concentrations were \\ stable for thousands of years at 270-280 parts per million volume (ppmv). Over the past \\ 100 years the concentration has risen to $364 \mathrm{ppmv}$, and continues to rise at a rate of $0.4 \%$ \\ per year (IPCC 1997). Elevated $\mathrm{CO}_{2}$ concentrations cause increased growth and \\ photosynthesis rates in most plants (Tissue and Oechel 1987, Fetcher et al. 1988, Sage \\ 1989, Idso and Kimball 1993, Masle et al. 1993, Luo et al. 1994, Sage 1994). This can \\ result in an increase in foliar carbon to nitrogen ratio $(\mathrm{C}: \mathrm{N})$, and other chemical changes \\ that affect the performance of insect herbivores and associated arthropod guilds \\ (reviewed by Coviella and Trumble 1999, Whittaker 1999). \\ $\mathrm{CO}_{2}$-mediated changes in plant chemistry appear to have altered performance in \\ most insect herbivore species studied (reviewed by Lincoln et al. 1993, Watt et al. 1995, \\ Lindroth 1996, Bezemer and Jones 1998, Coviella and Trumble 1999, Whittaker 1999). \\ Since $\mathrm{CO}_{2}$ tends to increase foliar $\mathrm{C}: \mathrm{N}$, and nitrogen is limiting in most herbivore diets \\ (Mattson 1980), indirect effects of elevated $\mathrm{CO}_{2}$ on insect folivore performance have \\ been negative overall (Bezemer and Jones 1998, Coviella and Trumble 1999). In most
}


cases, folivorous insects appear to have responded to lower $\mathrm{N}$ concentrations of elevated $\mathrm{CO}_{2}$-grown foliage with increased consumption rates (Coviella and Trumble 1999), but were unable to compensate enough to match the performance of those feeding on ambient $\mathrm{CO}_{2}$-grown foliage (Hattenschwiler and Schafellner 1999). Not only did host plant nitrogen content generally decrease under elevated $\mathrm{CO}_{2}$, but concentrations of defensive chemicals, such as phenols, that reduce insect performance sometimes increased (Lindroth 1996, Penuelas et al. 1996). Foliar concentrations of minerals such as potassium sometimes also decreased (Norby et al. 1996). Even when defensive chemical concentrations remained unchanged, higher consumption rates likely increased insect exposure to the chemicals (Lindroth and Kinney 1998). Reduced relative growth rates have been commonly observed (McDonald et al. 1999), generally resulting in decreased folivore weight, even when development time was extended (e.g. Hattenschwiler and Schafellner 1999). Sometimes folivore mortality increased under elevated $\mathrm{CO}_{2}$ (e.g. Fajer et al. 1989), and in the few population-level studies that have been done, folivore abundance was lower (Stiling et al. 1999, Bezemer and Jones 1998, and Whittaker 1999). Feeding on plants grown under elevated $\mathrm{CO}_{2}$ has not always negatively affected folivore performance; sometimes individual growth rate increased and occasionally larval mortality was lower (Bezemer and Jones 1998). Explanations for a lack of effects or positive effects on folivorous insects include: reduced sensitivity to host plant changes of later insect growth stages (Fajer 1989), greater environmental nitrogen availability (Goverde et al. 1999), specialized feeding on unaffected plant species or plant parts 
(Kerslake et al. 1998), and compensation for reduced nutritional value via increased consumption rate (Lindroth 1996).

The majority of elevated $\mathrm{CO}_{2}$ effects on fluid-feeder performance have been positive, and results have been less consistent than those recorded in folivore studies (Bezemer and Jones 1998, Coviella and Trumble 1999, Whittaker 1999). Positive fluidfeeder responses included increased fecundity and population density (Awmack et al. 1996, Salt et al. 1996, Smith 1996, Awmack et al. 1997, Docherty et al. 1997, Bezemer et al. 1998, Whittaker 1999). A few fluid feeders exhibited negative responses, including reduced population size (Butler 1985, Newman et al. 1999) and reduced fecundity and nymph weight (Docherty et al. 1997). Jones et al. (1998), recorded increased abundance of one aphid species and decreased abundance of another in the same model ecosystem experiment. Sometimes no effects of elevated $\mathrm{CO}_{2}$ on fluid-feeders were detected (Butler 1985, Butler et. al. 1986, Bezemer et al. 1998; Diaz et al., 1998).

Effects of elevated atmospheric $\mathrm{CO}_{2}$ on soil and litter-dwelling arthropods are only beginning to be investigated, but so far recorded effects on springtails (Collembola, common detritivore-fungivores) have been mixed. Elevated $\mathrm{CO}_{2}$ apparently resulted in increased total springtail abundance in model ecosystems with "soil that was relatively poor in nutrients," but some species' abundance increased while others decreased (Jones et al. 1998). However, in open top chambers under elevated $\mathrm{CO}_{2}$ concentration, springtail abundance decreased when soil nitrogen availability was also limited (Klironomous et al. 1997). 
Limited studies elevated $\mathrm{CO}_{2}$ effects at the third trophic level suggest that predators and parasitoids of herbivores will experience reduced population growth. Mortality of gypsy moth parasitoids increased under elevated $\mathrm{CO}_{2}$ in one study (Roth and Lindroth 1994). In a subsequent study, survival and adult female size decreased in a hymenopteran gypsy moth parasitoid, and maturation was slowed in a dipteran parasitoid, although pupal weights were higher in the dipteran parasitoid (Roth and Lindroth 1995). In agreement with Roth and Lindroth's $(1994,1995)$ results, the abundance of predatory flies associated with cotton was reduced in open-top elevated $\mathrm{CO}_{2}$ chambers (Butler 1985). Alternatively, parasitoid attack rate on leaf miners increased in open-top chambers with elevated $\mathrm{CO}_{2}$ levels (Stiling et al. 1999), suggesting that decreased parasitoid performance is not always the case.

In this study we employed a whole-ecosystem field manipulation to investigate effects of elevated $\mathrm{CO}_{2}$ on an ecological community, a higher and more complex organizational level than that at which most arthropod- $\mathrm{CO}_{2}$ studies had previously been done (Bezemer and Jones 1998, Coviella and Trumble 1999, Weiner 1996). Our goal was to identify promising candidate effects at the ecosystem level for further study at all hierarchical levels, and to begin to predict community composition under future atmospheric $\mathrm{CO}_{2}$ levels. As reviewed above, earlier organismal-level research suggested the following population-level responses to elevated $\mathrm{CO}_{2}$ :

- Folivores (such as Lepidoptera) will decrease in abundance.

- Fluid-feeding herbivores (such as Homoptera and herbivorous Heteroptera) will increase in abundance. 
- Parasitoids (such as parasitic Hymenoptera) will decrease in abundance.

\section{Methods}

Study site

In-situ $\mathrm{CO}_{2}$ manipulation in this study was accomplished usingpitfall trap arrays

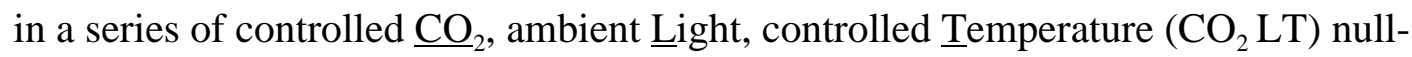
balance chambers (Oechel et al. 1994) and a Free-Atmosphere $\underline{\text { Carbon dioxide }}$ Enrichment (FACE) ring and control ring plots. The facility was located at the Sky Oaks Biological Research Station run by San Diego State University in a chamise (Adenostoma fasciculatum) dominated chaparral system in north-east San Diego County (1400 m elevation; $\left(33^{\circ} 23^{\prime} \mathrm{N}, 116^{\circ} 37^{\prime} \mathrm{W}\right)$. Co-dominant shrubs and sub-shrubs included cupleaf lilac (Ceanothus greggii), flat-top buckwheat (Eriogonum fasciculatum), matchweed (Gutierrezia sarothrae), and golden yarrow (Eriophylum confertiflorum). Redshank (Adenostoma sparsifolium) was also dominant in the system, but not present in any of the treatment or control plots. The chambers and ring plots were located within an area that burned in July 1992.

Experimental Design

The $\mathrm{CO}_{2} \mathrm{LT}$ experimental series consisted of 12 walk-in chambers, two each at set

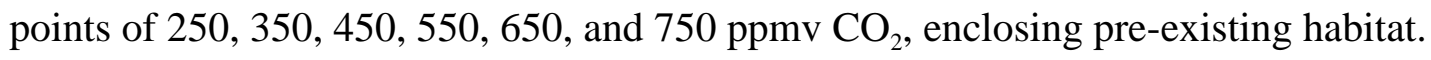
Chambers were roughly cubical with sloping roofs, enclosing an area approximately 1.8 $\mathrm{m}^{3}$. Treatments began December, 1995. Thus, habitat had been treated for 2 years prior to the first collections, and four years by the time collections were completed. 
Arthropods were collected using $50 \mathrm{ml}$ plastic cup pitfall traps filled with approximately $15 \mathrm{ml}$ of propylene glycol. Traps were set for two weeks, with two week intervals between sampling periods. Arthropods were collected in chambers over periods beginning April 14, May 10, August 26, and September 23 in 1997, and over periods beginning April 18, May 17, June 15, July 13, and August 21 in 1998. When not in use, sealed pitfall traps remained in the ground in order to minimize ground disturbance. Three traps were placed in each chamber. Trap locations were selected so that they were approximately a half meter apart in the center of the chamber floor. Collected arthropods were subsequently strained from the propylene glycol and stored in 70\% ethyl alcohol.

The FACE design consisted of a 15 m diameter FACE ring, and two proximal ambient control plots of the same dimension, one with a similar ring structure, and one without. The ring structures consisted of large plastic or metal pipes designed to deliver $\mathrm{CO}_{2}$ into the atmosphere within the plot. An average $\mathrm{CO}_{2}$ concentration of $550 \mathrm{ppmv}$ was maintained within the FACE ring starting in spring, 1996. The same type of pitfall traps used in the chambers was also used in the FACE and control rings. Thirty locations were selected randomly from within the $177 \mathrm{~m}^{2}$ ring plots. Arthropods were collected for 24 hours every two weeks in May and June of 1998. Collections were processed as in the $\mathrm{CO}_{2} \mathrm{LT}$ chamber study.

\section{Arthropod Identification}

Arthropods were identified to class, order, family (Bland 1978, Arnett et al. 1980, Stehr 1987, Borrer et al. 1992), and numbered morpho-species (putative species based on morphological similarity). Supervised assistants completed much of the identification 
using an arthropod morpho-species voucher collection built as the study progressed. Because arthropods are highly diverse, morpho-species are commonly used for large collections in ecological studies. Arthropod identification and classification methods employed in this study were similar to those of Oliver and Beattie (1996), who found that species counts were largely consistent whether supervised non-specialists sorted to morpho-species or specialists sorted to taxonomic species.

Selection of arthropod groups for analysis was based both on functional similarity and abundance of taxonimc groups in collections. Groups analyzed from chamber collections were: total arthropods, parasitoid wasps (Hymenoptera, primarily superfamilies Evanioidea, Ichneumonoidea, Chalcidoidea, and Proctotrupoidea), predatory arachnids (Aranae, predatory Acari, and Phalangida), moths (representing Lepidopetera, primarily Geometridae and Microlepidoptera; nectar feeders, pollinators, and folivores), a chamise-feeding moth species (Geometridae), fluid-feeding herbivores (Homoptera and herbivorous Heteroptera), springtails (Collembola; litterdwelling fungivore/detritivores), ants (Formicidae; a variety of feeding strategies, often omnivorous). The chamise-feeding moth species collected in the chambers was analyzed separately from other moths because they comprised a very large proportion of some of the group samples, particularly at higher $\mathrm{CO}_{2}$ concentrations. In contrast, no chamisefeeding moths were collected in the FACE study. Predatory arachnids and chamise moths were the only two groups analyzed in the chamber study that were not also analyzed in the FACE study, due to absence or extreme rarity in collections. 
Abundance of individuals/trap was calculated by averaging all collections within a year. A general linear regression model (SYSTAT version 8, copyright SPSS 1998) was used to analyze the response of arthropod abundance to $\mathrm{CO}_{2}$ treatment in the chambers. All collections within a year were averaged together because individual graphical analyses revealed generally consistent patterns among months. Combining data across dates effectively increased sampling intensity and strengthened effect signals. Log transformations of data $(\log$ or $\log$ of $x+1)$ were performed prior to analyses when data were not normally distributed. P values less than 0.05 were considered statistically significant. When only one (mean of less than 0.1 per trap) or no chamise-feeding moths were collected in a chamber within a year, data from that chamber was excluded from analysis, assuming that too few (if any) individuals occupied the chamber to permit a population-level response. It was not possible to test for statistically significant differences in mean arthropod abundance between $\mathrm{CO}_{2}$ treatments in the FACE study because the FACE ring was not replicated and traps within a ring-plot were not independent (Hurlbert 1984).

\section{Results}

Atmospheric $\mathrm{CO}_{2}$ concentrations appear to have more strongly affected arthropod abundances in the $\mathrm{CO}_{2}$ LT chambers in 1998, during the high precipitation El Niño season, than during the dry 1997 season (Figs. 1-8). Correlations between arthropod abundances were less likely to be due to chance in 1998 than in 1997 for all groups, although only 2 relationships were significant (Table 1). Total arthropod abundance and parasitic wasp abundance were negatively correlated with $\mathrm{CO}_{2}$ concentration in 1998 
(Figs. $1 \mathrm{~b}$ and $2 \mathrm{~b}$, Table 1). Fluid-feeding herbivores, ants, and arachnid predators were also negatively correlated with elevated $\mathrm{CO}_{2}$ in 1998 (Figs. 3b, 4b, and 5b), but the relationships were not statistically significant (Table 1). In contrast, abundance of the chamise-feeding moth species, when present, appeared to increase dramatically with elevated $\mathrm{CO}_{2}$, rising from a mean of 0.6 to 6.8 moths/chamber (Table 1, Fig. 6), and abundance of all other moths (excluding the chamise-feeding moth) also displayed a positive, but non-significant correlation with elevated $\mathrm{CO}_{2}$ (Table 1, Fig. 7b). The only groups that did not display linear relationships between abundance and $\mathrm{CO}_{2}$ concentration were springtails (Table 1, Fig. 8b) and predatory arachnids (Table 1, Fig 5b), although only the springtail relationship was significant. Springtail and predatory arachnid patterns suggested curvilinear relationships, with peak abundance near 450-550 ppmv, and lowest abundance at 750 ppmv (Table 1, Figs. 5b and 8b).

In agreement with the chamber data, all slopes of relationships between arthropod group abundance and $\mathrm{CO}_{2}$ concentration in the ring plot study (when analyzed) were in the same direction as found in the chamber study (Figs. 1-4, Figs. 7 and 8). Spatial distribution of ant abundance in the FACE ring did not appear to be correlated, and ant abundance was not correlated with fluid-feeder abundance.

\section{Discussion}

Abundance of parasitic wasps was lower under elevated $\mathrm{CO}_{2}$ as predicted, however, moth abundance appeared to have increased, not the effect suggested by earlier organismal studies. Mean fluid-feeder abundance decreased with elevated $\mathrm{CO}_{2}$ as expected, but the relationship in this study was not statistically significantly. The 
increased chamise-feeding moth abundance at elevated $\mathrm{CO}_{2}$ may reflect a response simlar to that of larvae of the common blue butterfly (Polyommatus icarus; Goverde et al. 1999). At elevated $\mathrm{CO}_{2}$, common blue butterfly larvae exhibited increased consumption of elevated $\mathrm{CO}_{2}$-grown plant material, more efficient conversion of ingested material, faster development, and higher weight, which should increase population growth rate. However, Goverde et al. (1999) attributed their atypical results to high foliar nitrogen concentration in the nitrogen fertilized, nitrogen-fixing Lotus corniculatus host plants, and chamise does not fix nitrogen, nor were our plots fertilized, so it is not clear why this species apparently benefited from elevated $\mathrm{CO}_{2}$ exposure. Perhaps direct exposure of larvae also contributed to positive moth performance, as indicated by Caulfield and Bunce' (1994) study with beet armyworms. They specifically designed an experiment to test for interaction between direct exposure of insects to and plant growth under elevated $\mathrm{CO}_{2}$. The most interesting result was that armyworm survival was enhanced on sugarbeet, but only for larvae exposed to elevated $\mathrm{CO}_{2}$ and fed elevated $\mathrm{CO}_{2}$ grown plants. Larvae not exposed to both manipulated atmosphere and foliage were unaffected. Our results also reinforce the cautionary observation that effects of elevated $\mathrm{CO}_{2}$ can appear strong and consistent for individual species or taxa in laboratory studies, but may be reversed or buffered in natural systems (reviewed by Koch and Mooney 1996, Korner and Bazzaz 1996, Weiner 1996). It is not surprising that the chamise-feeding moth response was not predicted by the majority of previous lepidopteran study results, and it is not the first effect of elevated $\mathrm{CO}_{2}$ at a greater hierarchical level found to be 
opposite of predictions based on responses at lower levels (Loehle 1995, Weiner 1996). For example, short-term leaf responses, like increased photosynthetic rates, have not always resulted in increased whole-plant biomass accumulation (Koch and Mooney 1996). Our study also suggests that while plant biomass probably increased with elevated $\mathrm{CO}_{2}$ (Oechel et al. 1997), arthropod biomass, in fact, may have. The implications of this with respect to ecosystem dynamics are critical, since declining arthropod populations could reduce nutrient cycling and energy flow to higher trophic levels.

The curvilinear relationship with elevated $\mathrm{CO}_{2}$ that we observed in springtails (1998), is similar to the relationship between fungal abundance and $\mathrm{CO}_{2}$ level seen in the same chambers (M. Allen pers. comm.) Changes in predatory arachnid, springtail, and fungal abundance may be directly related, since fungi are the primary food source of springtails, and spiders and mites are prominant predators in the litter and soil (Hopkin 1997). This curvilinear springtail- $\mathrm{CO}_{2}$ relationship provides an explaination for the seemingly contradictory results of Jones et al. (1998) and Klironomous et al. (1997). Jones et al. (1998) recorded higher springtail abundance at approximately $550 \mathrm{ppmv} \mathrm{CO}_{2}$ compared to ambient (approximately $350 \mathrm{ppmv}$ ), and Klironomous et al. (1997) recorded lower springtail abundance at $700 \mathrm{ppmv} \mathrm{CO}_{2}$ compared to ambient. Both sets of results were in agreement with the curvilinear springtail- $\mathrm{CO}_{2}$ relationship recorded here in 1998 (Fig. 8b). The relationship observed here should serve as a cautionary reminder regarding the assumption of linear relationships. Most elevated $\mathrm{CO}_{2}$ studies to date have compared only one ambient $\mathrm{CO}_{2}$ treatment (approx. $360 \mathrm{ppmv}$ ), to only one elevated $\mathrm{CO}_{2}$ treatment (anywhere from 550 to $750 \mathrm{ppmv}$ ), which are within the segment of our 
springtail response curve where abundance changes from an increasing trend to a decreasing one.

Some variability in results may also be due to experimental methodology. The difference in $\mathrm{CO}_{2}$ effect between years could be due to time (cumulative $\mathrm{CO}_{2}$ effect on plants and/or arthropods), climatic factors (an interaction with the $\mathrm{CO}_{2}$ effect), or both. Increased arthropod abundance during a wetter, more productive season likely increased capture rate in 1998, strengthening effect signals. Weaker support for arthropod $\mathrm{CO}_{2}$ effects in the FACE study than in the chamber study can be explained, in part, by a difference in methods. The FACE study had only two $\mathrm{CO}_{2}$ treatments with a difference of approximately 200 ppmv, while chamber treatments included six $\mathrm{CO}_{2}$ levels spanning 500 ppmv. Collections made over a shorter time period in FACE study traps than in the chamber traps (24 hours as opposed to two weeks) resulting in lower numbers of arthropods collected/trap simply due to a difference in trapping methods.

Another possible methodological effect may have been reflected in chamisefeeding moth results. Chamise-feeding moths were not collected in the FACE study, but they were so abundant in one chamber that they entirely defoliated the chamise. The absence of chamise-feeding moths from FACE study collections indicates the outbreaklevel abundance of that species in the chambers was possibly the result of an interaction between structural effects of the chmbers and $\mathrm{CO}_{2}$ level. Similar outbreaks (not correlated with $\mathrm{CO}_{2}$ level) unique to the chambers were noted in two species of scale insect (Hemiptera: Homoptera) in the field. It is also possible that the lack of an enclosing structure may have resulted in differential movement of mobile arthropod 
groups in or out of the FACE ring, further increasing the differences in abundance caused by $\mathrm{CO}_{2}$ level compared to the chambers.

Our results reinforce Weiner's (1996) emphasis that, given the complexity of natural systems, there is a great need for in situ, "whole ecosystem," studies to more accurately predict future regional ecosystem states. However, our results also indicate that greater replication within and across $\mathrm{CO}_{2}$ levels will be needed in FACE designs to achieve the power required to detect these type of effects on arthropod populations. The most promising future research avenues suggested by this study are those leading to understanding higher-level arthropod-mediated ecological functions in general, and specific effects related to parasitic wasps, moths, and springtails.

\section{Literature cited}

Arnett, R.H., N.M. Downie, and H.E. Jaques. 1980. How to know the Beetles. Wm. C. Brown Company Publishers, Dubuqe, Iowa, USA.

Awmack, C.S., R. Harrington, and S.R. Leather. 1997. Host plant effects on the performance of the aphid Aulacorthum solani (Kalt.) (Homoptera: Aphididae) at ambient and elevated $\mathrm{CO}_{2}$. Global Change Biology 3: 545-549.

Awmack, C.S., R. Harrington, S.R. Leather, and J.H. Lawton. 1996. The impacts of elevated $\mathrm{CO}_{2}$ on aphid-plant interactions. Aspects of Applied Biology 45: 317-322.

Bezemer, T.J. and T.H. Jones. 1998. Plant-insect herbivore interactions in elevated atmospheric $\mathrm{CO}_{2}$ : Quantitative analyses and guild effects. Oikos 82: 212-222.

Bezemer, T.J., T.H. Jones, and K.J. Knight. 1998. Long-term effects of elevated $\mathrm{CO}_{2}$ and temperature on populations of the peach potato aphid Myzus persicae and its parasitoid Aphidius matricariae. Oecologia 116: 128-135.

Bland, R.G. 1978. How to Know the Insects. Wm. C. Brown Company Publishers, Dubuqe, Iowa, USA.

Borrer, D.J., C.A. Triplehorn, and N.F. Johnson. 1992. An Introduction to the Study of Insects. Harcort Brace College Publishers, Fort Worth, Texas, USA.

Butler, G.D., Jr. 1985. Populations of several insects on cotton (Gosypium hirsutum cultivar Deltapine 61) in open-top carbon dioxide enrichment chambers. Southwestern Entomol. 10: 264-267. 
Butler, G.D. Jr., B.A. Kimball, and J.R. Mauney. 1986. Populations of Bemesia tabaci (Homoptera: Aleyrodidae) on cotton (Gosypium hirsutum cultivar Deltapine 61) in opentop chambers enriched with carbon dioxide. Environmental Entomology 15: 61-63.

Caulfield F., and J.A. Bunce. 1994. Elevated atmospheric carbon dioxide concentration affects interactions between Spodoptera exigua (Lepidoptera: Noctuidae) larvae and two host plant species outdoors. Environmental. Entomolology 23: 999-1005.

Coviella, C.E. and J.T. Trumble. 1999. Effects of elevated atmospheric carbon dioxide on insect-plant interactions. Conservation Biology 13:700-712.

Diaz, S., L.H. Fraser, J.P. Grime, V. Falczuk. 1998. The impact of elevated $\mathrm{CO}_{2}$ on plantherbivore interactions: experimental evidence of moderating effects at the community level. Oecologia 117: 177-186.

Docherty, M., F.A. Wade, D.K. Hurst, J.B. Whittaker, and P.J. Lea. 1997. Responses of treesap feeding herbivores to elevated $\mathrm{CO}_{2}$. Global Change Biology 3: 51-59.

Fajer, E.D. 1989. The effects of enriched $\mathrm{CO}_{2}$ atmospheres on plant-insect herbivore interactions: growth responses of larvae of the specialist butterfly, Junonia coenia (Lepidoptera: Nymphalidae). Oecologia. 81: 514 -520.

Fajer, E.D., M.D. Bowers, and F.A. Bazzaz. 1989. The effects of enriched carbon dioxide atmospheres on plant-insect herbivore interactions. Science 243:1198-1200.

Fetcher, N., C.H. Jaeger, B.R. Strain, and N. Sionit. 1988. Long-term elevation of atmospheric $\mathrm{CO}_{2}$ concentration and the carbon exchange rates of saplings of Pinus and Liquidamber styraciflua (L.) Tree Physiology 4: 255-262.

Goverde, M., A. Bazin, J.A. Shykoff, and A. Erhardt. 1999. Influence of leaf chemistry of Lotus corniculatus (Fabacae) on larval development of Polymmatus icarus (Lepidoptera, Lycaenidae): Effects of elevated $\mathrm{CO}_{2}$ and plant genotype. Functional Ecology 13: 801810.

Hattenschwiler, S., and C. Schafellner. 1999. Opposing effects of elevated $\mathrm{CO}_{2}$ and $\mathrm{N}$ deposition on Lymantria monacha larvae feeding on spruce trees. Oecologia 118: 210217.

Hopkin, S.P. 1997. Biology of the Springtails (Insecta: Collembola). Oxford University Press, Oxford, Connecticut, USA.

Hurlbert, S.H. 1984. Pseudoreplication and the design of ecological field experiments. Ecological Monogographs 54: 187-211.

Idso, S.B. and B.A. Kimball. 1993. Tree growth in carbon dioxide enriched air and its implications for global carbon cycling and maximum levels of $\mathrm{CO}_{2}$. Global Biogeochemistry Cycles 7: 537-555.

IPCC (Intergovernmental Panel on Climate Change). 1997. Climate Change 1996: The Science of Climate Change. J.T. Houghten, L.G. Meira Filho, B.A. Callander, N. Harris, A Kattenberg and K. Maskell editors. Cambridge University Press, Cambridge, Massachusetts, USA

Jones, T.H., L.J. Thompson, J.H. Lawton, T.M. Bezemer, R.D. Bardgett, T.M. Blackburn, K.D. Bruce, P.F. Cannon, G.S. Hall, S.E. Hartley, G. Howson, C.G. Jones, C. Kampichler, E. 
Kandeler, and D.A. Ritchie. 1998. Impacts of rising atmospheric carbon dioxide on model terrestrial ecosystems. Science 280: 441-443.

Klironomos, J.N., M.C. Rillig, M.F. Allen, D.R. Zak, M. Kubiske, and K.S. Pregitzer. 1997. Soil fungal-arthropod responses to Populus tremuloides grown under enriched atmospheric $\mathrm{CO}_{2}$ under field conditions. Global Change Biology 3: 101-106.

Kerslake, J.E., S.J. Woodin, and S.E. Hartley. 1998. Effects of carbon dioxide and nitrogen on a plant-insect interaction: the quality of Calluna vulgaris as a host for Operophtera brumata. New Phytologist 140: 43-53.

Koch, G.W. and H.A. Mooney editors. 1996. Carbon Dioxide and Terrestrial Ecosystems. Academic Press, San Diego, California, USA.

Korner, C. and F.A. Bazzaz editors. 1996. Carbon dioxide, Populations, and Communities. Academic Press, San Diego, California, USA.

Lincoln, D.E., E.D. Fajer, and R.H. Johnson. 1993. Plant-insect herbivore interactions in elevated $\mathrm{CO}_{2}$ environments. Trends in Ecology and Evolution 8: 64-68.

Lindroth, R.L. 1996. $\mathrm{CO}_{2}$-mediated changes in tree chemistry and tree-Lepidoptera interactions. In G.W. Koch and H.A. Mooney editors. Carbon Dioxide and Terrestrial Ecosystems. Academic Press, San Diego, California, USA.

Lindroth, D.E. and K.K. Kinney. 1998. Consequences of enriched atmospheric $\mathrm{CO}_{2}$ and defoliation for foliar chemistry and gypsy moth performance. Journal of Chemical Ecology 24: 1677-1695.

Loehle, C. 1995. Anomolous responses of plants to $\mathrm{CO}_{2}$ enrichment. Oikos 73: 181-187.

Luo, Y., C.B. Field, and H.A. Mooney. 1994. Predicting responses of photosynthesis and root fraction to elevated $\left[\mathrm{CO}_{2}\right]$ : interactions among carbon, nitrogen, and growth. Plant, Cell and Environment 17: 1195-1204.

Masle, J., G.S. Hudson, and M.R. Badger. 1993. Effects of ambient $\mathrm{CO}_{2}$ concentration on growth and nitrogen use in tobacco (Nicotiana tabacum) plants transformed with an antisense gene to the small subunit of ribulose-1, 5-biphosphate carboxylase/oxygenase. Plant Physiology 103: 1075-1088.

Mattson, W.J. 1980. Herbivory in relation to plant nitrogen content. Ann. Rev. Ecol. Syst. 11:119-161.

McDonald, E.P., J. Agrell, and R.L. lindroth. 1999. $\mathrm{CO}_{2}$ and light effects on deciduous trees: growth, foliar chemistry, and insect performance. Oecologia 119: 389-399.

Newman, J.A., D.J. Gibson, E. Hickman, M. Lorenz, E. Adams, L. Bybee, and R. Thompson. 1999. Elevated carbon-dioxide results in smaller populations of the bird cherry-oat aphid Ropalosiphum padi. Ecological Entomology 24: 486-489.

Norby, R.J., S.D. Wullschleger, and C.A. Gunderson. 1996. Tree responses to elevated $\mathrm{CO}_{2}$ and implications for forests. In G.W. Koch and H.A. Mooney editors. Carbon Dioxide and Terrestrial Ecosystems. Academic Press, San Diego, California, USA.

Oechel, W.C., S. Cowles, N. Grulke, S. J. Hastings, B. Lawrence, T. Prudhomme, G. Riechers, B. Strain, and George Vourlitis. 1994. Transient nature of $\mathrm{CO}_{2}$ fertilization in Arctic tundra. Nature 371: 500-503. 
Oechel, W.C., S.J. Hastings, S. Roberts, and P. Bryant. 1997. Effects of elevated $\mathrm{CO}_{2}$ on water use and net $\mathrm{CO}_{2}$ flux in chaparral using FACE and $\mathrm{CO}_{2} \mathrm{LT}$ approaches. Pages 51-52 in abstracts, MEDECOS VII Conference on Mediterranean-type Ecosystems, Oct 18-26. Global Change Research Group, Department of Biology, San Diego State University, San diego, California, USA.

Oechel, W.C., S.J. Hastings, G.L. Vourlitis, M. A. Jenkins, and C.L. Hinkson. 1995. Direct effects of elevated $\mathrm{CO}_{2}$ in chaparral and Mediterranean-type ecosystems. Pages 58-75 in J. Moreno and W. Oechel editors. Global Change and Mediterranean-Type Ecosystems. Academic Press, San Diego, California, USA.

Oliver and Beattie. 1996. Designing a cost-effective invertebrate survey: A test of methods for rapid assessment of biodiversity. Ecological Applications 2: 594-607.

Penuelas, J., M. Estiarte, B.A. Kimball, S.B. Idso, P.J. Pinter, G,W, Wall, R.L. Garcia, D.J. Hansaker, R.L. Lamorte, and D.L. Hendrix. 1996. Variety of responses of plant phenolic concentration to $\mathrm{CO}_{2}$ enrichment. Journal of Expererimental Botony 47: 1463-1467.

Roth, S.K. and R.L. Lindroth. 1994. Effects of $\mathrm{CO}_{2}$-mediated changes in paper birch and white pine chemistry on gypsy moth performance. Oecologia 98: 133-138.

Roth, S.K. and R.L. Lindroth. 1995. Elevated atmospheric $\mathrm{CO}_{2}$ effects on phytochemistry, insect performance, and insect-parasitoid interactions. Global Change Biology 1: 173182.

Sage, R.F, T.D. Sharkey, and J.R. Seeman. 1989. Acclimation of photosynthesis to increasing atmospheric $\mathrm{CO}_{2}$ in five $\mathrm{C}_{3}$ species. Plant Physiology 89: 590-596.

Sage, R.F. 1994. Acclimation of photosynthesis to increasing atmospheric $\mathrm{CO}_{2}$ : The gas exchange perspective. Photosynthesis Research 39: 351-68.

Salt, D.T., P. Fenwick, and J.B. Whittaker. 1996. Interspecific herbivore interactions in a high $\mathrm{CO}_{2}$ environment: root and shoot aphids feeding on Cardamine. Oikos 77: 326-330.

Smith, H. 1996. The effects of elevated $\mathrm{CO}_{2}$ on aphids. Antenna 20: 109-111.

Stehr, F.W. editor. 1987. Immature insects. Volumes 1 and 2. Kendall/Hunt Publishing Company, Dubuque, Iowa, USA.

Stiling, P., A.M. Ross, B. Hungate, P. Dijkstra, C.R. Hinkle, W.M. Knott, and B. Drake. 1999. Decreased leaf-miner abundance in elevated $\mathrm{CO}_{2}$ : Reduced leaf quality and increased parasitoid attack. Ecological Applications 9: 240-244.

Tissue D.T. and W.C. Oechel. 1987. Response of Eriophorum vaginatum to elevated $\mathrm{CO}_{2}$ and temperature in the Alaskan arctic tundra. Ecology 68: 401-41

Watt, A.D., J.B. Whittaker, M. Docherty, G. Brooks, E. Lindsay, and D.T. Salt. 1995. The impact of elevated atmospheric $\mathrm{CO}_{2}$ on insect herbivores. Pages 198-217 in R.

Harrington and N.E. Stork editors. Insects in a Changing Environment. $17^{\text {th }}$ Symposium of the Royal Entomological Society. Academic press, London, England.

Weiner, J. 1996. Problems predicting the ecological effects of elevated $\mathrm{CO}_{2}$. In: Carbon Dioxide. 431-440 in C. Korner and F.A. Bazzaz editors. Populations, and Communities. Academic Press, San Diego, California, USA.

Whittaker, J.B. 1999. Impacts and responses at the population level of herbivorous insects to elevated $\mathrm{CO}_{2}$. European Journal of Entomology 96: 149-156. 
Table 1. Regression statistics for arthropod abundance vs. $\mathrm{CO}_{2}$ concentrations in chambers $\left(\mathrm{n}=12\right.$ chambers at $6 \mathrm{CO}_{2}$ levels; see text for details). Polynomial regressions are denoted by an *.

\begin{tabular}{|c|c|c|c|c|c|c|}
\hline \multirow[t]{2}{*}{ Arthropod Group } & 1997 & 1997 & 1997 & 1998 & 1998 & 1998 \\
\hline & $r^{2}$ & slope & $\mathrm{P}$ & $r^{2}$ & slope & $\mathrm{P}$ \\
\hline Total arthropods (log 98) & $6.7 \%$ & $-7.42 \mathrm{E}-4$ & 0.418 & $44.2 \%$ & $-1.05 \mathrm{E}-3$ & 0.018 \\
\hline Parasitic wasps $(\log 98)$ & $4.9 \%$ & $-1.55 \mathrm{E}-3$ & 0.490 & $51.3 \%$ & $-8.22 \mathrm{E}-4$ & 0.009 \\
\hline Fluid-feeding herbivores $(\log )$ & $0.2 \%$ & $9.92 \mathrm{E}-5$ & 0.894 & $21.3 \%$ & $-1.51 \mathrm{E}-3$ & 0.131 \\
\hline Ants $(\log )$ & $5.5 \%$ & $-3.38 \mathrm{E}-4$ & 0.465 & $22.6 \%$ & $-8.84 \mathrm{E}-4$ & 0.118 \\
\hline Arachnid predators & $7.2 \%$ & $-7.42 \mathrm{E}-4$ & 0.397 & $8.2 \%$ & $-1.05 \mathrm{E}-3$ & 0.366 \\
\hline & - & - & - & $39.7 \% *$ & - & $0.103^{*}$ \\
\hline Chamise-feeding moths & - & - & - & $98.2 \%$ & $1.25 \mathrm{E}-2$ & 0.006 \\
\hline Other moths $(\log )$ & $1.3 \%$ & $-1.31 \mathrm{E}-4$ & 0.729 & $10.4 \%$ & $2.33 \mathrm{E}-4$ & 0.306 \\
\hline Springtails & $7.3 \%$ & $-1.05 \mathrm{E}-3$ & 0.395 & $11.5 \%$ & $-7.88 \mathrm{E}-4$ & 0.281 \\
\hline & - & - & - & $70.0 \% *$ & - & $0.004 *$ \\
\hline
\end{tabular}



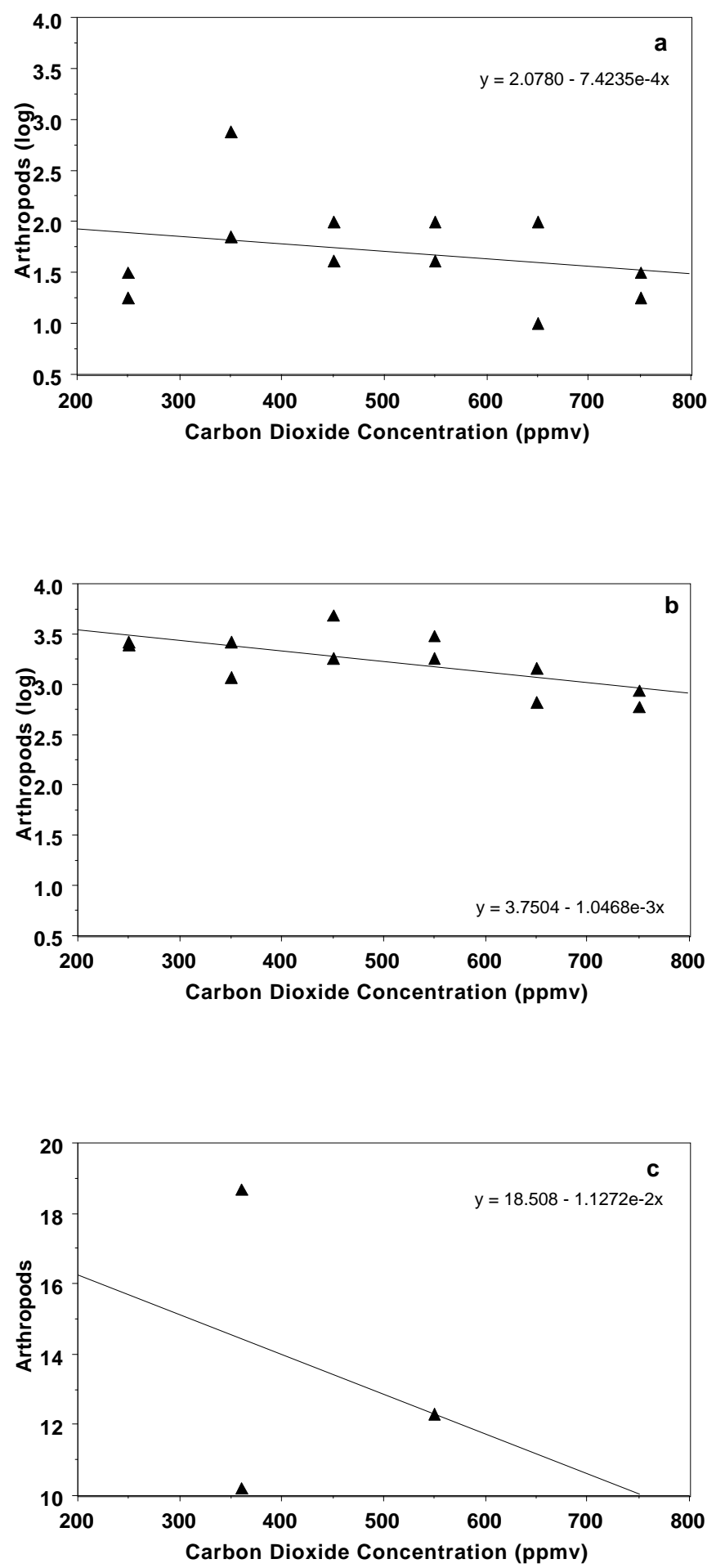

Figure 1. Arthropod abundance in $\mathrm{CO}_{2} \mathrm{LT}$ chambers, April-September, a) 1997 and b) 1998, and c) in ring plots, May-June, 1998. Data are averages of 5 collection periods for each chamber ( $n=15$ traps), and 4 collection periods for each ring plot ( $n=120$ traps). 

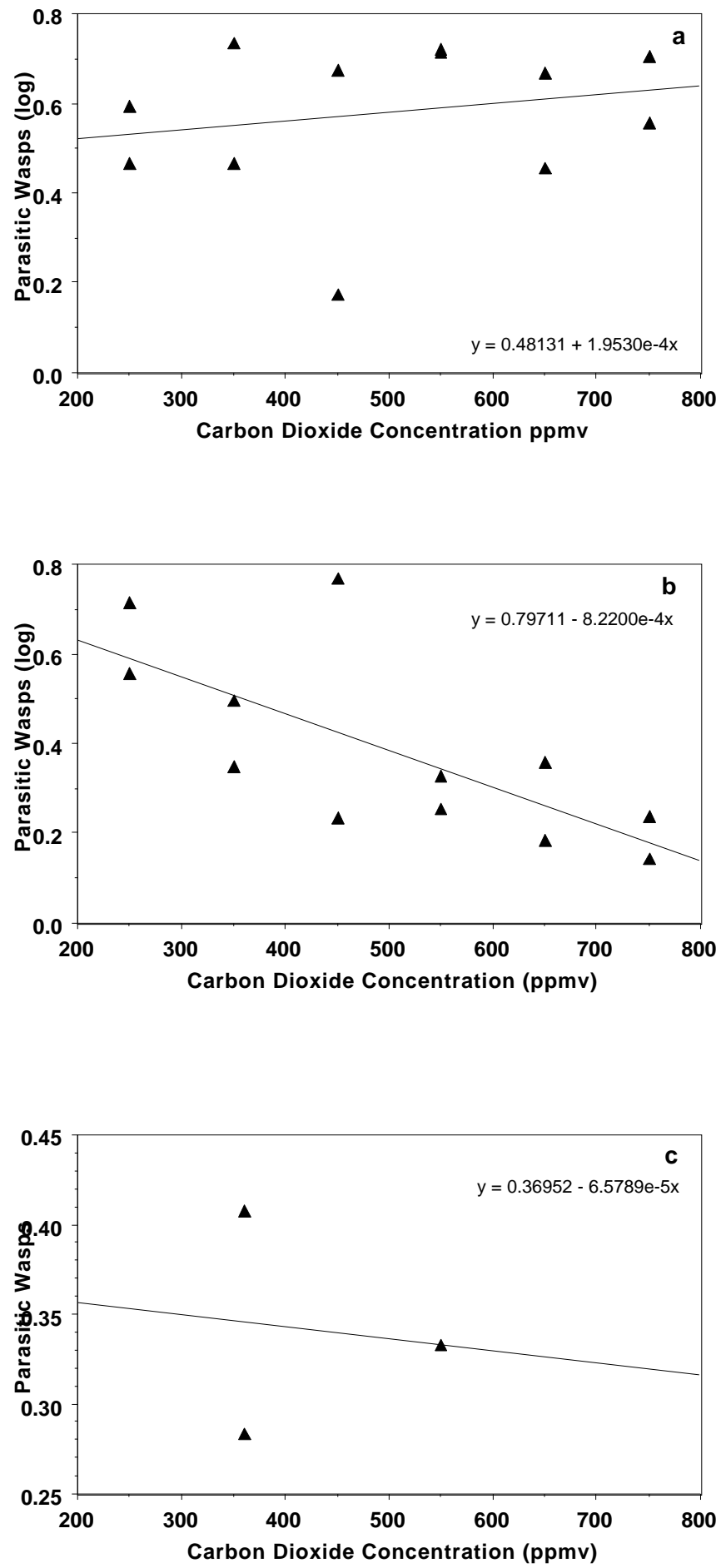

Figure 2. Parasitic wasp abundance in $\mathrm{CO}_{2} \mathrm{LT}$ chambers, April-September, a) 1997 and b) 1998, and c) in ring plots, May-June, 1998. Data are averages of 5 collection periods for each chamber ( $n=15$ traps), and 4 collection periods for each ring plot ( $n=120$ traps). 

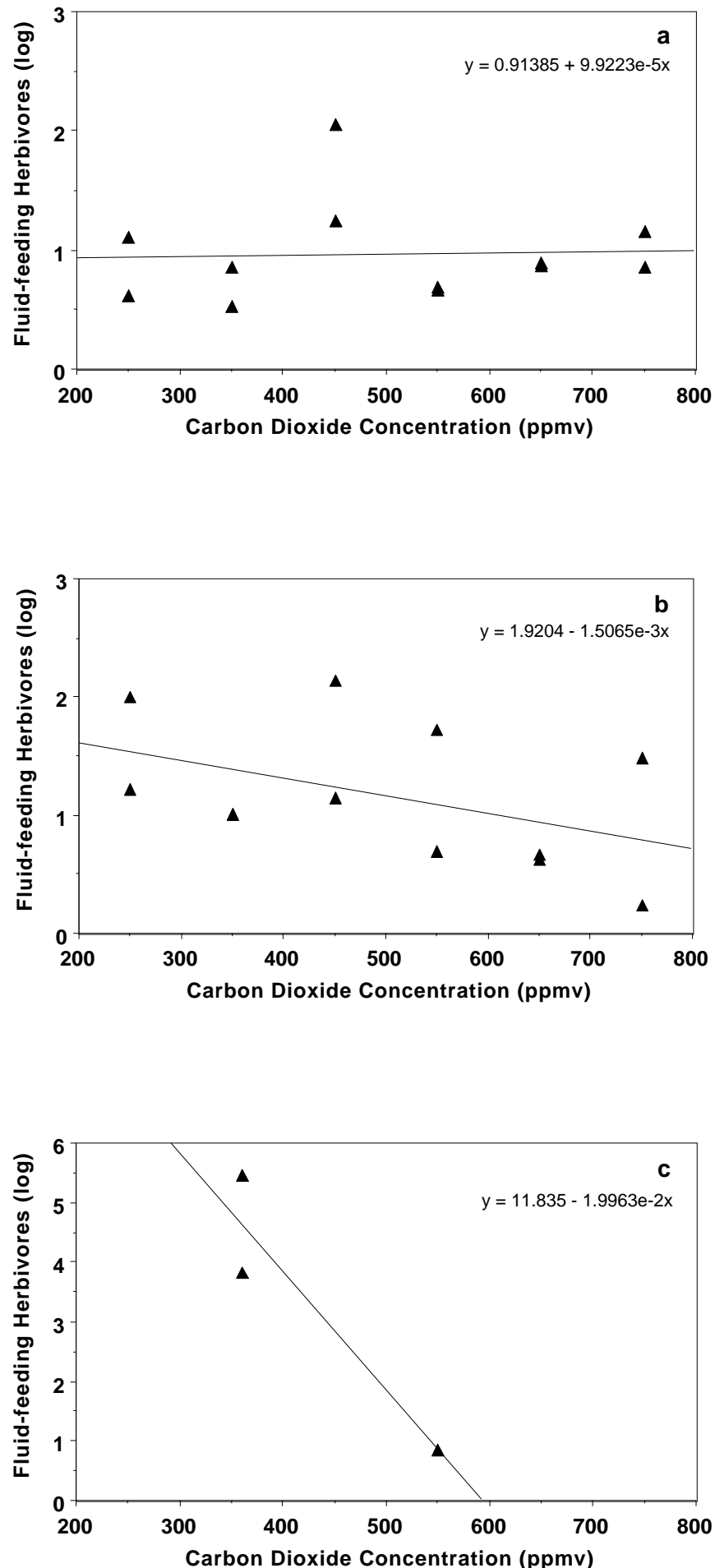

Figure 3. Fluid-feeder abundance in $\mathrm{CO}_{2} \mathrm{LT}$ chambers, April-September, a) 1997 and b) 1998, and c) in ring plots, May-June, 1998. Data are averages of 5 collection periods for each chamber ( $n=15$ traps), and 4 collection periods for each ring plot ( $n=120$ traps). 

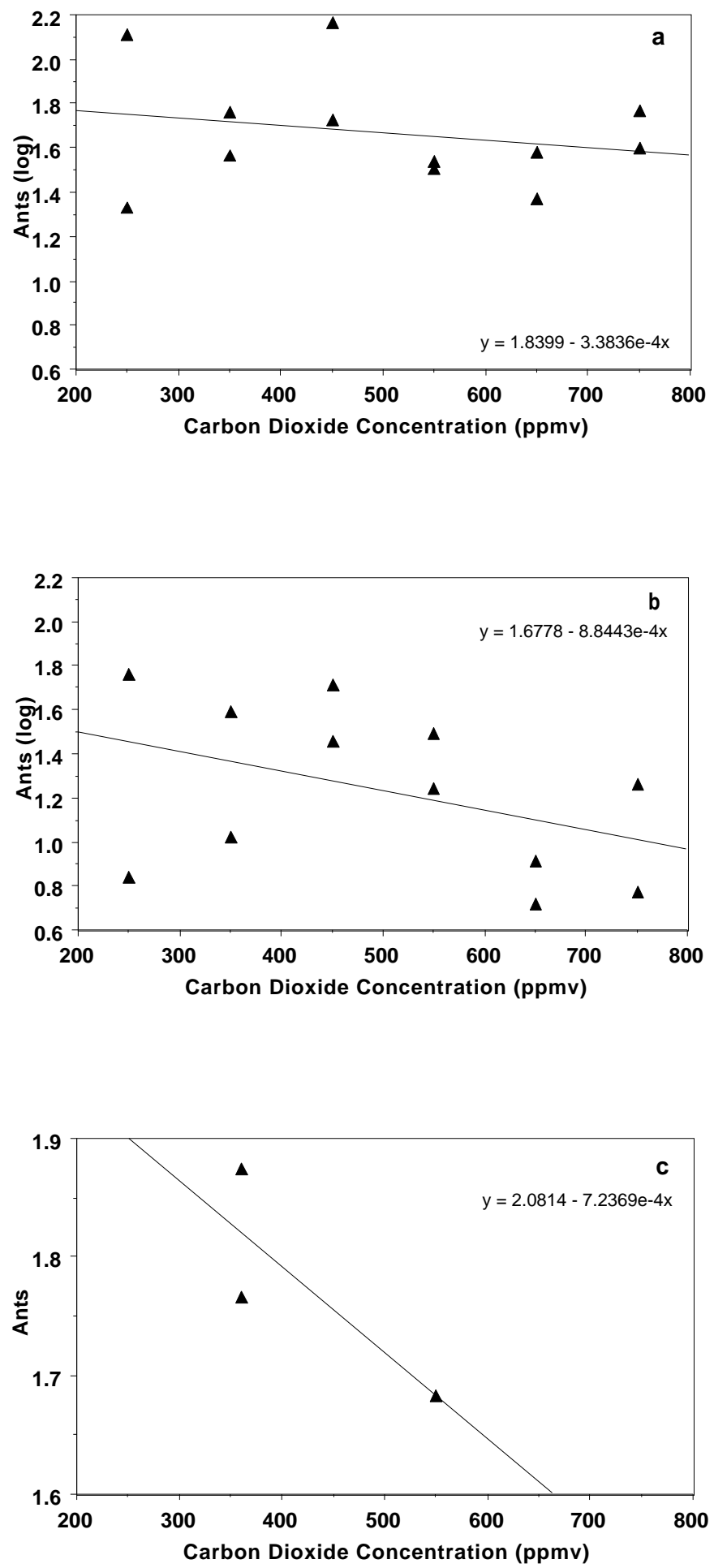

Figure 4. Ant abundance in $\mathrm{CO}_{2} \mathrm{LT}$ chambers, April-September, a) 1997 and b) 1998, and c) in ring plots, May-June, 1998. Data are averages of 5 collection periods for each chamber ( $n=15$ traps), and 4 collection periods for each ring plot ( $n=120$ traps). 

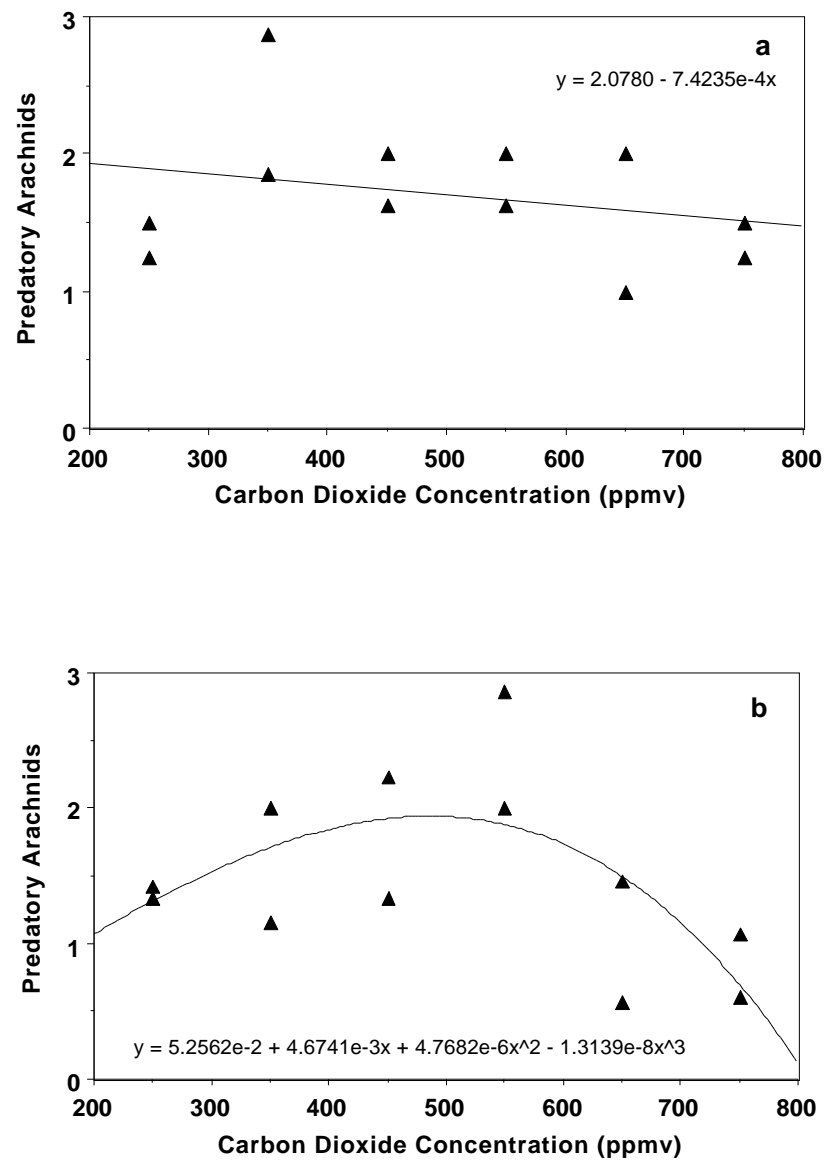

Figure 5. Predatory Arachnid abundance in $\mathrm{CO}_{2} \mathrm{LT}$ chambers, April-September, a) 1997 and b) 1998. Data are averages of 5 collection periods for each chamber ( $n=15$ traps).

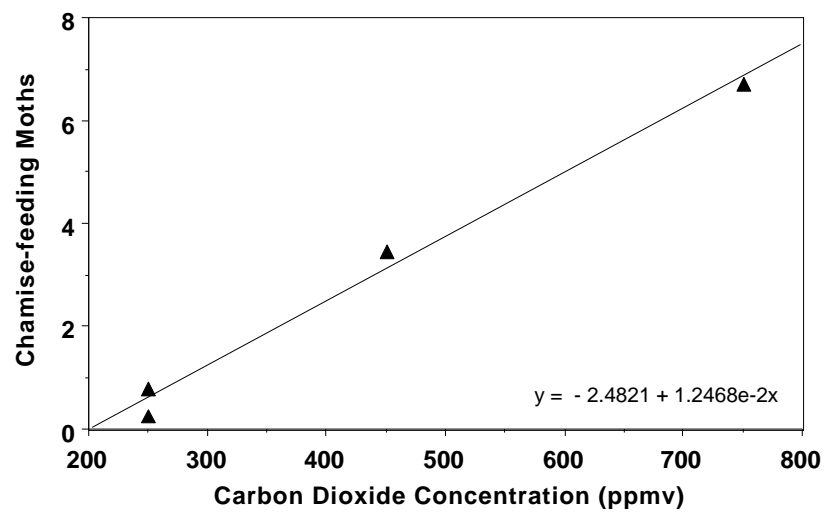

Figure 6. Chamise-feeding moth abundance in $\mathrm{CO}_{2} \mathrm{LT}$ chambers, April-September, 1998. Data are averages of 5 collection periods for each chamber $(n=15$ traps). 

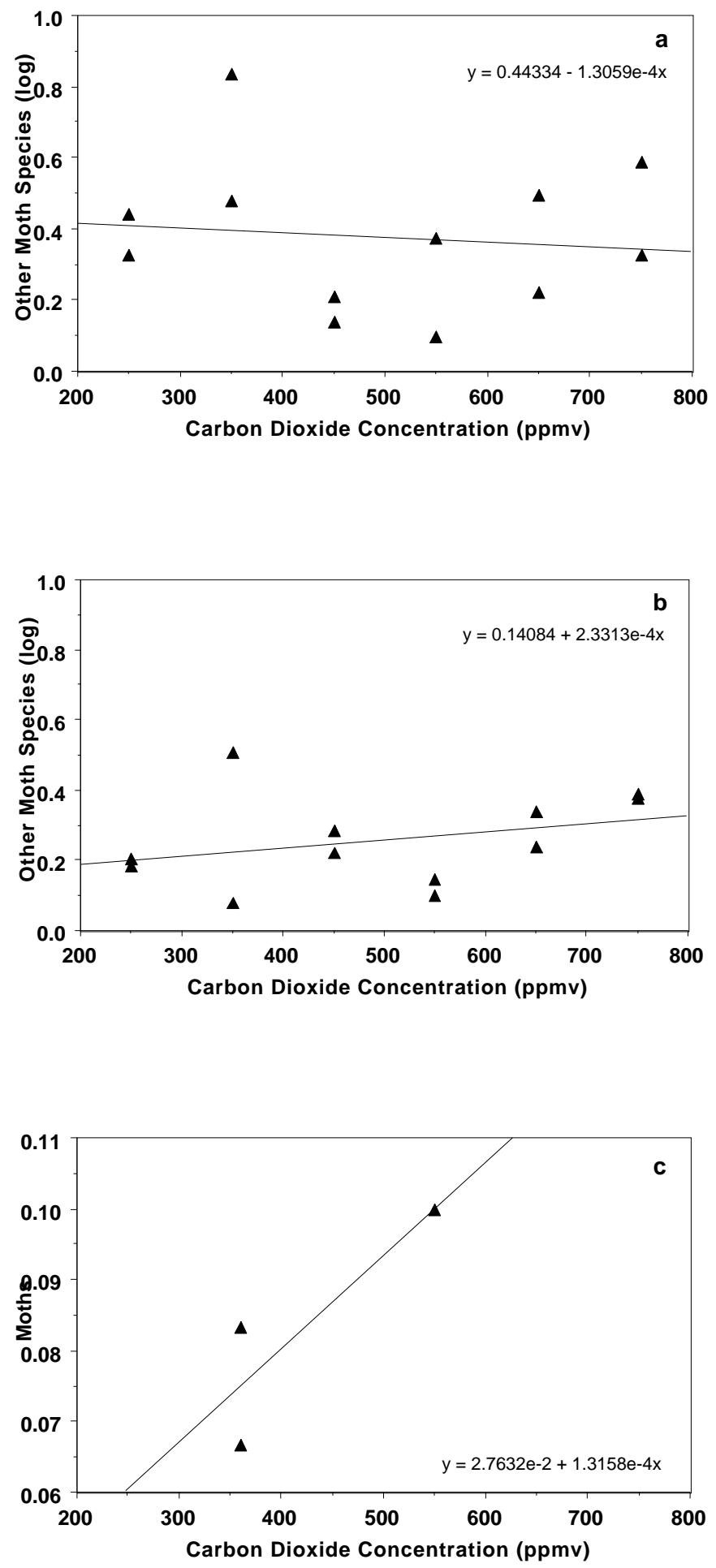

Figure 7. Other moth abundance in $\mathrm{CO}_{2} \mathrm{LT}$ chambers, April-September, a) 1997 and b) 1998, and c) in ring plots, May-June, 1998. Data are averages of 5 collection periods for each chamber ( $n=15$ traps), and 4 collection periods for each ring plot ( $n=120$ traps). 

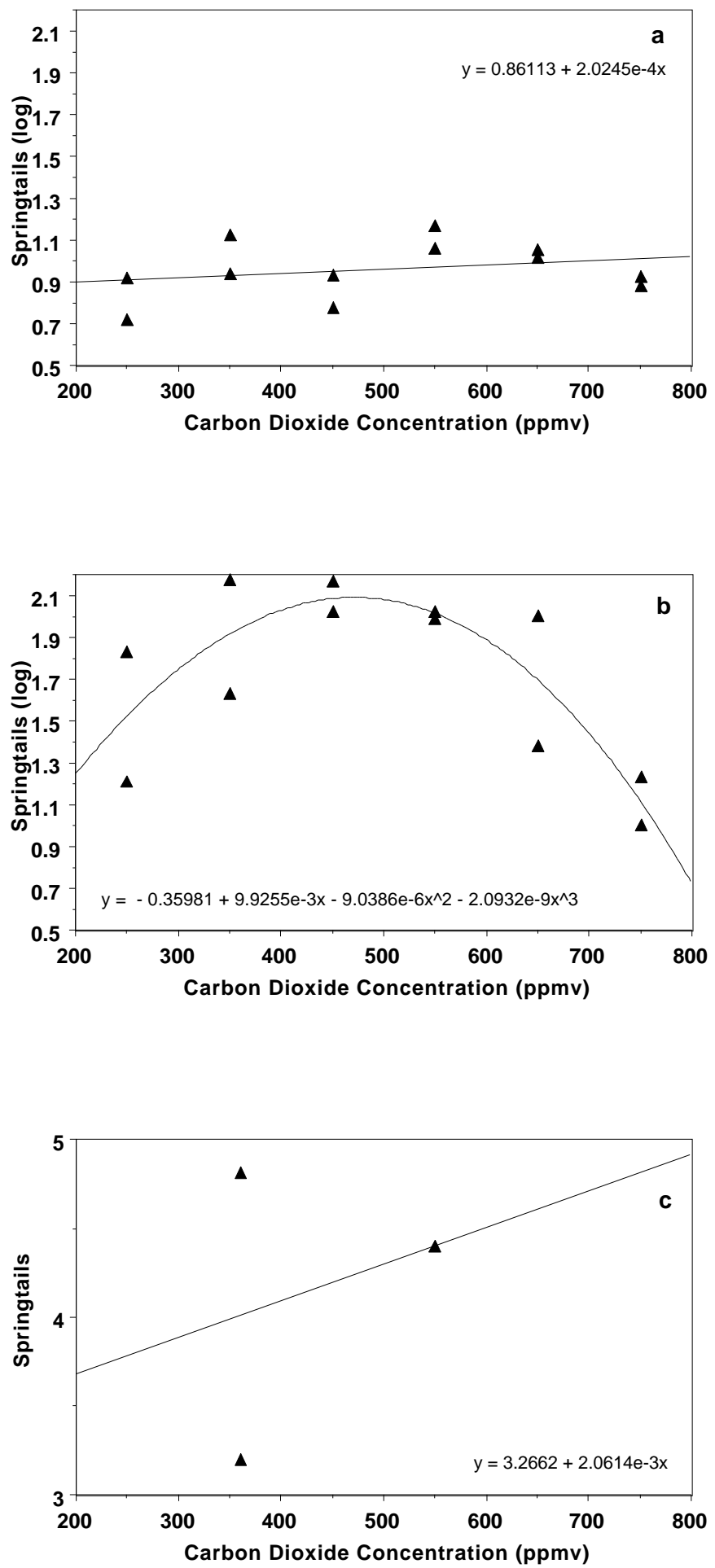

Figure 8. Springtail abundance in $\mathrm{CO}_{2} \mathrm{LT}$ chambers, April-September, a) 1997 and b) 1998, and c) in ring plots, May-June, 1998. Data are averages of 5 collection periods for each chamber ( $n=15$ traps), and 4 collection periods for each ring plot ( $n=120$ traps). 


\section{The relationship between atmospheric $\mathrm{CO}_{2}$ concentration and arthropod diversity in chaparral, and a model of the relationship between $\mathrm{CO}_{2}$ and succession.}

\section{Alison Eileen Williams}

\section{Introduction}

\section{Background}

An increase in overall plant productivity and other ecological effects of elevated atmospheric $\mathrm{CO}_{2}$ (DeLucia et al. 1999, Mellilo et al. 1995, Oechel et al. 1997) should alter species diversity of the chaparral community. In particular, elevated $\mathrm{CO}_{2}$ should increase growth rates of plant roots (Arnone et al. 2000, Mikan et al. 2000, Van Ginkel et al. 2000) and shoots (Oechel et al. 1995, IPCC 1997). Although the effects of elevated $\mathrm{CO}_{2}$ on arthropod species diversity and composition in chaparral has not been studied, plant species diversity has been found to increase in grassland communities. Three year exposure of a grassland community to elevated atmospheric $\mathrm{CO}_{2}$ led to greater plant species richness and heterogeneity (species diversity) (Potvin and Vasseur 1997). Specifically, growth of dicots was stimulated more than monocots under elevated $\mathrm{CO}_{2}$, and complete coexistence of early and late successional species was enhanced. A similar pattern was observed in a Kansas prairie, where abundance of C3 grasses declined and C3 forbs increased, while C4 species abundance remained unchanged (Owensby et al. 1993). Decreased dominance among herbacious plant types and increased growth rate of woody plants should increase insect habitat heterogeneity, both in architectural growth forms and host-plant species diversity, and therefore increase insect species diversity (Southwood et al. 1979, Strong et al. 1984, Lawton 1983). 
Conceptual Succession-CO-Diversity Model and Hypothesis

Earlier results suggest that arthropod and plant diversity should first increase after fire, and then decrease as shrub biomass accumulates. It is known that plant species diversity is lowest in chaparral when shrub biomass reaches its maximum (Force 1981). Furthermore, studies of insect family and plant species diversity in two chaparral communities found increases in diversity during the first three years after fire (Force 1981, Mills 1985). Mills (1985) studied post-fire insect succession in the same chamise chaparral community studied here, and found that insect family diversity (Simpson's index) almost doubled the second year after fire. In a chaparral succession model (Fig. 1) we can assume that maximum arthropod diversity and habitat heterogeneity is achieved at approximately half way to maximum canopy closure, when intermediate shrub biomass and the mix of early and late successional species has maximized the structural complexity and species diversity of the vegetation. This model is analogous to the commonly observed intermediate disturbance pattern (Sousa 1979, Petraitis et al. 1989); early successional stage (typical of frequently disturbed communities) results in low community diversity, intermediate successional stage (typical of communities experiencing intermediate disturbance frequencies) results in high community diversity, and late successional stage (typical of infrequently disturbed communities) again results in lower community diversity.

Research suggests that $\mathrm{CO}_{2}$ enrichment will increase the rate of canopy closure, generally speeding ecological succession (see Swank and Oechel 1991. All else being equal, the relationship between diversity and $\mathrm{CO}_{2}$ level should be affected by the difference in shrub biomass accumulation caused by increased $\mathrm{CO}_{2}$ levels. Adenostoma fasciculatum 
(chamise shrub) growth and physiology measurements taken concurrent to this study (shoot growth, net primary productivity; Y. Cheng, unpublished data) indicate that the difference in annual shrub growth caused by 100 ppmv elevated $\mathrm{CO}_{2}$ is less than would be expected over a two year period at a fixed $\mathrm{CO}_{2}$ level. Maximum shrub biomass in chaparral is generally reached in 20-30 years (Reid 1985, Black 1987), and the chamise chaparral community in this study was in its fifth year of postfire succession, putting the ambient (360 ppmv) system approximately one quarter of the way to maximum canopy closure, and probably half way to maximum habitat heterogeneity and arthropod species diversity (Fig. 1). Using conservative estimates of 20 years to maximum shrub biomass, and a two year growth differences caused by 100 ppmv elevated $\mathrm{CO}_{2}$, we can a hypothesis regarding the slope of the $\mathrm{CO}_{2}$-diversity relationship in our study (Fig. 1). Therefore, the chaparral succession model predicts diversity at the time our data were collected should increase as $\mathrm{CO}_{2}$ levels rise from $250 \mathrm{ppmv}$ to $750 \mathrm{ppmv}$ (Fig. 1; as in grasslands, Potvin and Vasseur 1997, Owensby et al. 1993). Thus, we can use the results of this study to test the model prediction that in the chaparral system and post-fire period studied here, insect diversity and atmospheric $\mathrm{CO}_{2}$ concentration will be positively correlated.

Although specific predictions are difficult to make, we also expected to find shifts in the dominance of arthropod groups among atmospheric $\mathrm{CO}_{2}$ treatments and between experimental designs (below). Elevated $\mathrm{CO}_{2}$ has been found to affect the relative abundance of aphid (Homoptera), springtail (Collembola), and soil fungal species (Klironomous et al. 1997, Jones et al. 1998). Design differences between $\mathrm{CO}_{2}$ enrichment technologies, particularly enclosure of plots, should also alter relative abundance of arthropod taxons. For example, in the FACE ring, flying insects may be either attracted or 
repelled by elevated $\mathrm{CO}_{2}$ or its effect on the plant community, and in the chambers, restricted movement of arthropod species could have produced founder effects. Other structural effects of the chambers, such as the lack of precipitation on foliage (collected precipitation is redistributed at ground-level), may also have affected arthropods differently than in the open ring plots.

\section{Methods}

Experimental design and arthropod collection and identification methods were as described in Chapter 1. Diversity refers to how many species there are (richness) and their abundance relative to others (heterogeneity) (Hurlbert 1971, Force 1981, Magurran 1988, Krebs 1989). For example, a collection would be considered more diverse than another if the number of individuals was more evenly distributed among species, even if both collections contain the same number of species. Diversity was measured in this study using rarefaction. Rarefaction produces a species richness value that adjusts for sample size bias, and also accounts for the relative abundance (evenness or dominance) of species (Hurlbert 1971, Smith and Grassle 1977). The rarefaction index at $m=2$ is algebraically equivalent to 1 - 1/Simpson's index of diversity (Smith and Grassle 1977). Rarefaction calculations were performed using the modified Coleman function (Brewer and Williamson 1994):

$s_{m}=S-\mathrm{S}(1-m / N)^{n} i$

where $S=$ the number of species in the collection, $N=$ the total number of individuals in the collection, $n_{i}=$ the number of individuals in the $i^{\text {th }}$ species in the collection, $m=$ the sample 
size of individuals (in this study $m=$ the smallest sample size, 125), and $s_{m}=$ the expected number of species in $m$. Linear regression (SYSTAT version 8, copyright SPSS 1998) was used to analyze the diversity- $\mathrm{CO}_{2}$ relationship.

\section{Results and Discussion}

Arthropod abundance and diversity

Unlike arthropod abundance (data presented in Chapter 1) and absolute species richness (richness practically mirrored abundance), diversity $\left(s_{m}\right)$ did not decrease with increasing $\mathrm{CO}_{2}$ levels (Fig. 2). Although the positive relationship between arthropod diversity and $\mathrm{CO}_{2}$ was not statistically significant (Fig. 2, $\mathrm{F}=2.56, \mathrm{P}=0.14, \mathrm{r}^{2}=0.20$ ), it was consistent with the model-generated hypothesis that elevated $\mathrm{CO}_{2}$ increases arthropod species diversity in the early post-fire chaparral community. However, if elevated $\mathrm{CO}_{2}$ speeds succession as hypothesized, this positive relationship may be ephemeral, and elevated $\mathrm{CO}_{2}$ could begin to decrease plant diversity and increase dominance of shrub species 8-10 years after fire, compared to lower $\mathrm{CO}_{2}$ levels (see top axis of Fig. 1).

Relative abundance of arthropod groups in the chambers and ring plots at corresponding $\mathrm{CO}_{2}$ concentrations were similar (Fig. 3), with some minor differences. Consistently higher parasitic wasp abundance in the open ring plots compared to closed chambers (Fig. 3), and the lack of chamise-feeding moths in the FACE ring (data presented in Chapter 1), indicated that chamber enclosure did affect the population sizes of some species. Comparison of the relative abundance of arthropod groups collected between the FACE ring and $\mathrm{CO}_{2} \mathrm{LT}$ chambers indicates that our results may be generally applicable to the natural, non-enclosed community. 


\section{Conceptual Model Predictions}

Although it is perhaps premature to speculate just how elevated $\mathrm{CO}_{2}$ might affect the complex functioning of the chaparral community, there is no doubt it will alter community composition. If fire (or other disturbance) frequency is not similarly increased, faster succession would result in less total area of early successional habitat within the chaparral community at any point in time. Also, unless annual seed production and/or seedling establishment were also increased, annual plant species would not be able to build as large a viable seed bank prior to canopy closure, possibly reducing population densities

during subsequent post-burn succession events. All else being equal, the species-area curve (Gleason 1922, Williams 1943) predicts that lower abundance of hostplants and reduced habitat area would result in reduced arthropod diversity. Insect species that rely on early successional annual hostplants or nectar sources should also be negatively affected by a decrease in the total area of early-successional habitat, because there would be a decreased number of immigrants for recolonization. Thus, while community diversity may be increased by elevated atmospheric $\mathrm{CO}_{2}$ during the early post-fire period in chaparral communities in the future, peak diversity at mid-succession should not be higher, and could even be lower, than it would have been under lower $\mathrm{CO}_{2}$ levels, and that seral stage may be shorter lived (Fig. 1). This succession hypothesis further illustrates why it is unwise to assume a simple, static, linear relationship between $\mathrm{CO}_{2}$ concentration and ecological response. 


\section{Literature cited}

Arnone, J.A., J.G. Zaller, E.M. Spehn, P.A. Niklaus, C.E. Wells, and C. Korner. 2000. Dynamics of root systems in native grasslands: Effects of elevated atmospheric $\mathrm{CO}_{2}$. New Phytologist 147: 73-85.

Black, C.H. 1987. Biomass, nitrogen, and phosphorus accumulation over a southern California fire cycle chronosequence. In J.D. Tenhunen, F. Catarino, O.L. Lange, and W.C. Oechel editors. Plant Response to Stress: Functional Analysis in Mediterranean Ecosystems. Springer-Verlag, Heidelberg, Germany.

Brewer, A. and M. Williamson. 1994. A new relationship for rarefaction. Biodiversity Conservation 3: 373-379.

DeLucia, E.H., J.G. Hamilton, S.L. Naidu, R.B. Thomas, J.A. Andrews, A. Finzi, M. Lavine, R. Matamala, J.E. Mohan, G.R. Hendry, W.H. Schlesinger. 1999. Net primary production of a forest ecosystem with experimental $\mathrm{CO}_{2}$ enrichment. Science 284: 1177-1179.

Force, D.C. 1981. Postfire insect succession in southern California chaparral. American Naturalist 117: 575-582.

Gleason, H.A. 1922. On the relation between species and area. Ecology 3: 158-162.

Hurlbert, S.H. 1971. The nonconcept of species diversity: A critique and alternative parameters. Ecology 54: 427-431.

IPCC (Intergovernmental Panel on Climate Change). 1997. Climate Change 1996: The Science of Climate Change. J.T. Houghten, L.G. Meira Filho, B.A. Callander, N. Harris, A Kattenberg and K. Maskell editors. Cambridge University Press, Cambridge, Massachusetts, USA.

Jones, T.H., L.J. Thompson, J.H. Lawton, T.M. Bezemer, R.D. Bardgett, T.M. Blackburn, K.D. Bruce, P.F. Cannon, G.S. Hall, S.E. Hartley, G. Howson, C.G. Jones, C. Kampichler, E. Kandeler, and D.A. Ritchie. 1998. Impacts of rising atmospheric carbon dioxide on model terrestrial ecosystems. Science 280: 441-443.

Klironomos, J.N., M.C. Rillig, M.F. Allen, D.R. Zak, M. Kubiske, and K.S. Pregitzer. 1997. Soil fungal-arthropod responses to Populus tremuloides grown under enriched atmospheric $\mathrm{CO}_{2}$ under field conditions. Global Change Biology 3: 101106.

Krebs, C.J. 1989. Ecological Methodology. Harper and Row, New York, New York, USA.

Lawton, J.H. 1983. Plant architecture and the diversity of phytophagous insects. Annual Review of Entomology 28: 23-29.

Magurran, A.E. 1988. Ecological Diversity and Its Measurement. Princeton University Press, Princeton, New Jersey, USA.

Melillo, J.M., I.C. Prentice, G.D. Farquhar, E.-D. Schulze, and O.E. Sala. 1995. Terrestrial biotic responses to environmental change and feedbacks to climate. Pages 445-481 in J.T. Houghten, L.G. Meira Filho, B.A. Callander, N. Harris, A Kattenberg and K. Maskell editors. Climate Change 1996: The Science of Climate Change. Cambridge University Press, Cambridge, Massachusetts, USA.

Mikan, C. J., D.R. Zak, M.E. Kubiske, and K. S. Pregitzer. 2000. Combined effects of atmospheric $\mathrm{CO}_{2}$ and $\mathrm{N}$ availability on the belowground carbon and nitrogen dynamics of aspen mesocosms. Oecologia 124: 432-445. 
Mills, J.N. 1985. Herbivores and early postfire succession in southern California chaparral. PhD Dissertation, University of California, Davis and San Diego State University, San Diego, California, USA.

Oechel, W.C., S.J. Hastings, G.L. Vourlitis, M.A. Jenkins, and C.L. Hinkson. 1995. Direct effects of elevated $\mathrm{CO}_{2}$ in chaparral and Mediterranean-type ecosystems. Pages 5875 in J. Moreno and W. Oechel editors. Global Change and Mediterranean-Type Ecosystems. Springer-Verlag, New York, New York, USA.

Oechel, W.C., S.J. Hastings, S. Roberts, and P. Bryant. 1997. Effects of elevated $\mathrm{CO}_{2}$ on water use and net $\mathrm{CO}_{2}$ flux in chaparral using FACE and $\mathrm{CO}_{2} \mathrm{LT}$ approaches. Pages 51-52 in Proceedings of MEDECOS VII Conference on Medeterranean-type Ecosystems. San Diego, California, Oct 18-26. Department of Biology, San Diego State University, San Diego, California, USA.

Owensby, C.E., P.I. Coyne, J.M. Ham, L.M. Auen, and A.K. Knapp. 1993. Biomass production in a tallgrass prairie ecosystem exposed to ambient and elevated $\mathrm{CO}_{2}$. Ecological Applications 3: 644-653.

Petraitis, P.S., R.E. Latham, and R.A. Niesenbaum. 1989. The maintenance of species diversity by disturbance. Quarterly Review of Biology 64: 393-418.

Potvin, C. and L. Vasseur. 1997. Long-term $\mathrm{CO}_{2}$ enrichment of a pasture community: Species richness, dominance, and succession. Pages 347-360 in C. Korner and F.A. Bazzaz editors. Carbon Dioxide, Populations, and Communities. Academic Press, San Diego, USA.

Reid, C.D. 1985. Possible physiological indicators of senescence in two chaparral shrub species along a fire-induced age gradient. M.S. Thesis. San Diego State University, San Diego, California, USA.

Smith, W. and J.F. Grassle. 1977. Nonparametric estimation of species richness. Biometrics 40: 119-129.

Sousa, W.P. 1979. Disturbance in marine intertidal boulder fields: The nonequilibrium maintenance of species diversity. Ecology 60: 1225-1239.

Southwood, T.R.E., V.K. Brown, and P.M. Reader. 1979. The relationships of plant and insect diversities in succession. Biological Journal of the Linnean Society 12: 327348.

Strong, D.R.,Watt J.H. Lawton, and T.R.E Southwood. 1984. Insects on Plants: Community Patterns and Mechanisms. Harvard University Press, Cambridge, Massachusetts, USA.

Swak, S.E. and W.C. Oechel. 1991. Interactions among the effects of herbivory, competition, and resource limitation on chaparral herbs. Ecology 72: 104-115.

Van Ginkel, J.H., A. Gorissen, and D. Polci. 2000. Elevated atmospheric carbon dioxide concentration: Effects of increased carbon input in a Lolium perenne soil on microorganisms and decomposition. Soil Biology and Biochemistry 32: 449-456.

Watt, A.S. 1947. Pattern and process in the plant community. Journal of Ecology 35: 1-22.

Williams, C.B. 1943. Area and the number of species. Nature 152: 264-297. 


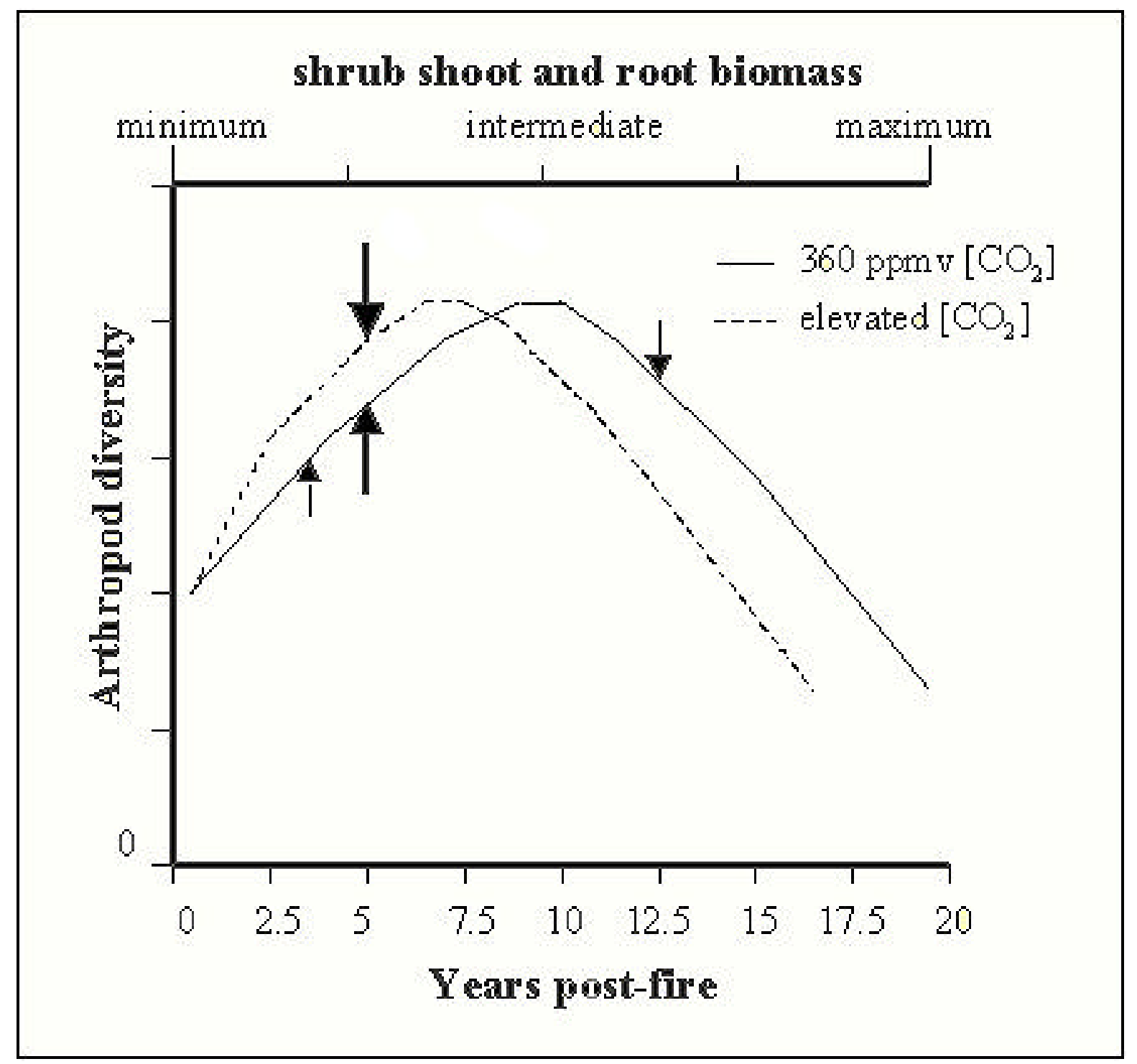

Figure 1. Conceptual succession- $\mathrm{CO}_{2}$-diversity model for chaparral. Large arrows indicate predicted arthropod diversity levels during this study (5 years after fire). Small arrows indicate predicted arthropod diversity levels on the ambient (360 ppmv) curve in the lowest (250 ppmv) and highest (750 ppmv) $\mathrm{CO}_{2}$ levels in $\mathrm{CO}_{2} \mathrm{LT}$ chambers, if the change in

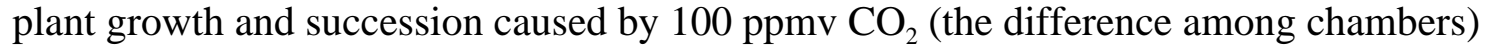
were equivalent to 2 years ambient growth. 


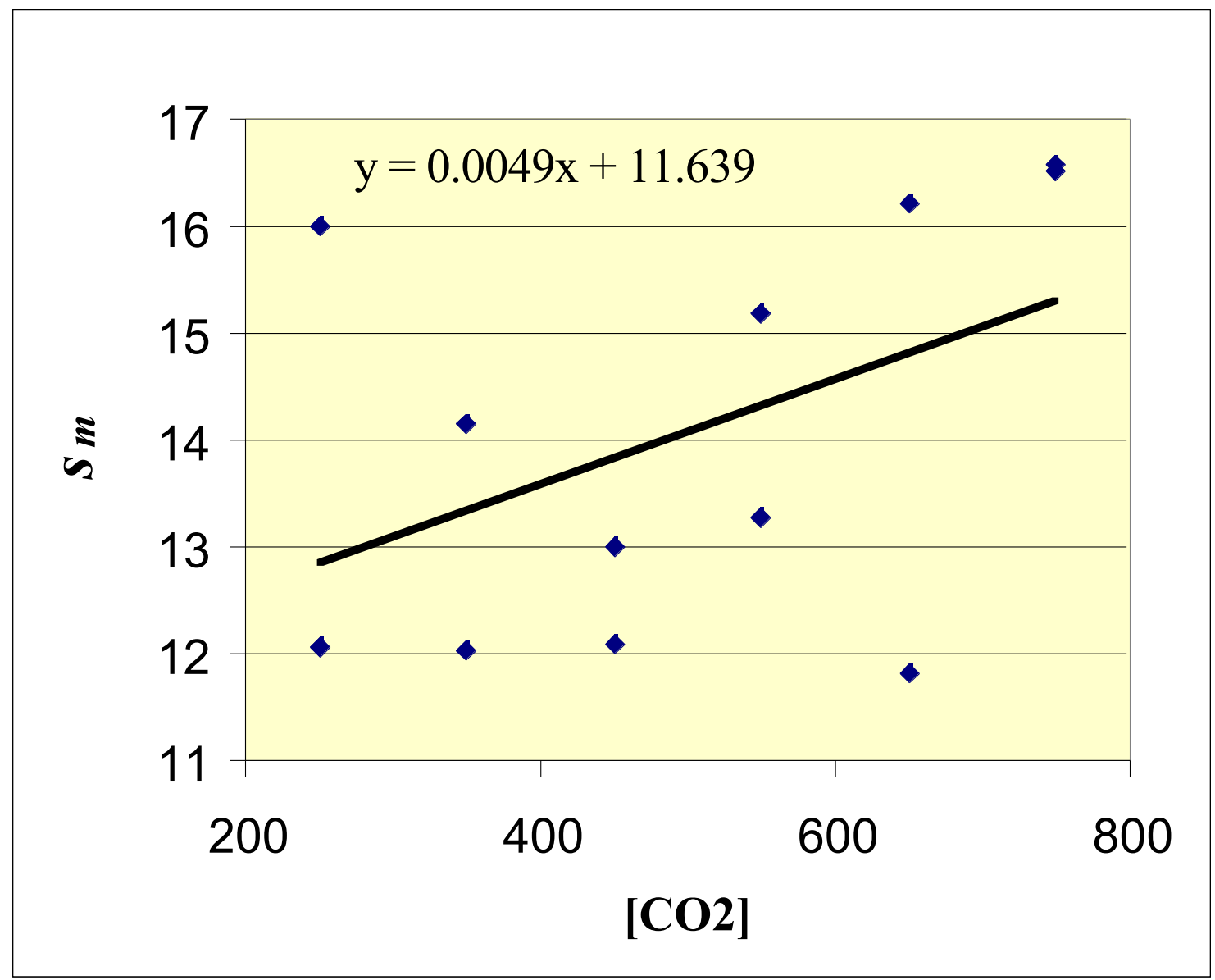

Figure 2. Arthropod species diversity in $\mathrm{CO}_{2} \mathrm{LT}$ chambers, April-October 1998. Each data point represents expected sample species richness $\left(s_{m}=\right.$ modified Coleman's function rarefaction value, a species diversity index) at smallest sample size $(m=125)$, averaged across 5 dates for each chamber at each $\mathrm{CO}_{2}$ level. 
Figure 3. Relative abundance of arthropod groups from the FACE ring ( 550 ppmv $\mathrm{CO}_{2}$ ), ambient ring plots (approximatly 360 ppmv), and $\mathrm{CO}_{2} \mathrm{LT}$ chambers, at 250, 350, 550, and 750 ppmv $\mathrm{CO}_{2}$ in 1998. Values represent a proportion of the total collection for each group, calculated using average individuals per trap for each treatment method. 
250 ppmv $\mathrm{CO}_{2} \mathrm{LT}$ chambers

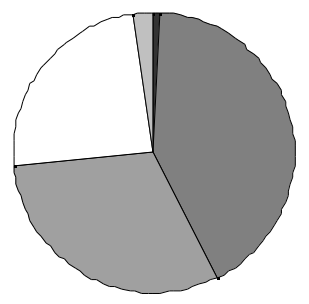

350 ppmv $\mathrm{CO}_{2} \mathrm{LT}$ chamber

Ambient ring plots
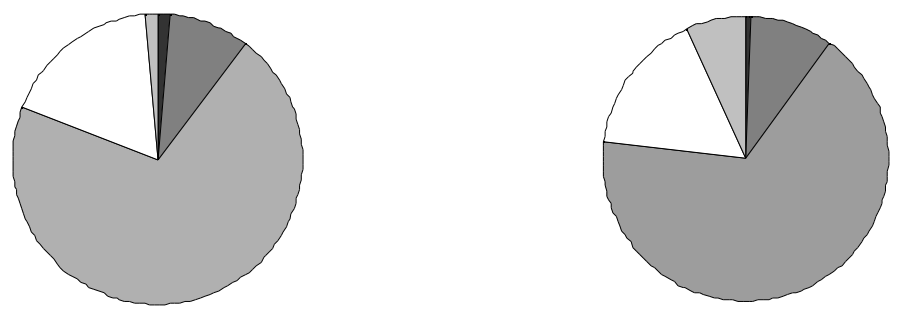

550 ppmv CO2LT chamber

550 ppmv FACE ring
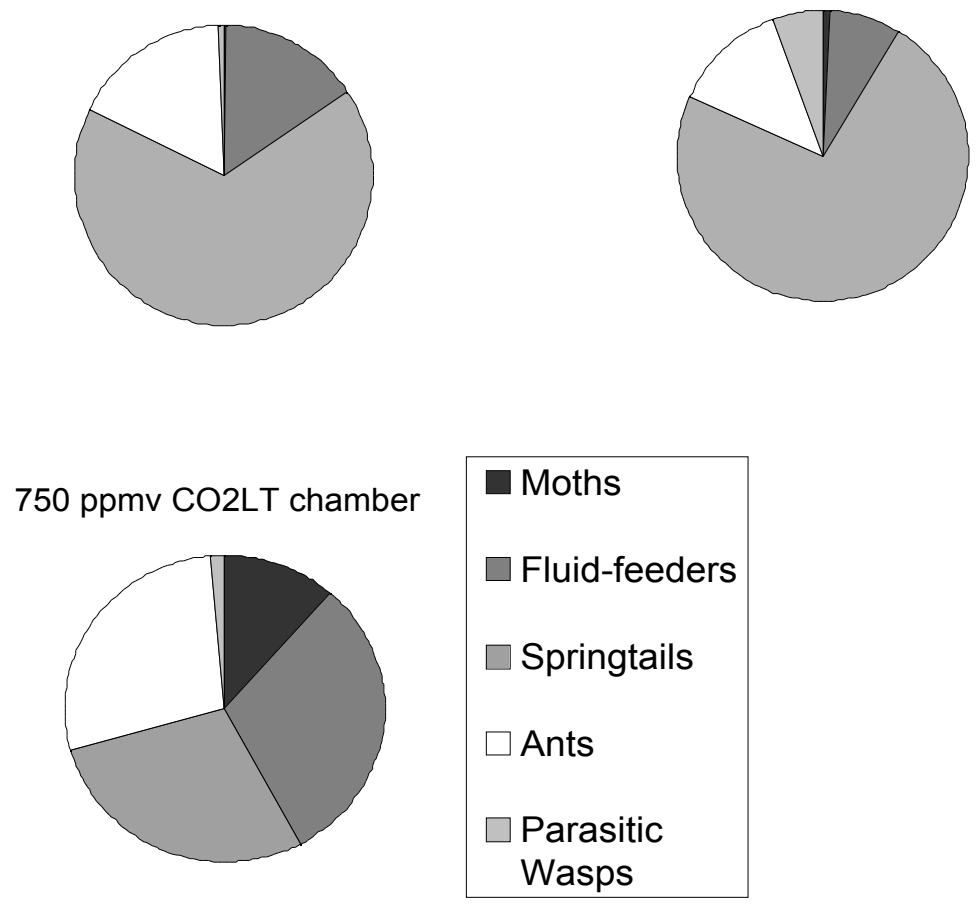


\title{
Effects of elevated atmospheric $\mathrm{CO}_{2}$ and hostplant density on psyllid abundance
}

\begin{abstract}
Alison Eileen Williams
\end{abstract}
Introduction

Herbivory, particularly by bark lice (Hemiptera: Homoptera: Psyllidae), has the potential to play a large part in regulating the post-fire abundance of key shrub species in the chaparral community (Mills 1985, Moreno and Oechel 1992). Ceanothus greggii is a common shrub species in chamise chaparral, and must regrow from seed after fire (Moreno and Oechel 1992). Two studies of the post-fire relationship between C. greggii and its herbivores in the same chaparral system studied here found that psyllids reduced survivorship and decreased the relative abundance of C. greggii. In 1982 and 1983 (Mills 1985), $73 \%$ of naturally-growing C. greggii seedlings surveyed at Sky Oaks Biological Field Station had psyllid infestations, and insecticide-treated seedlings survived significantly better than untreated seedlings (Mills 1985). Although none of the seedlings appeared to have died as a direct result of psyllid damage, $15 \%$ of the infested seedlings died from drought stress the following year. None of the non-infested seedlings died. Psyllids also significantly reduced the mean growth rate of infested seedlings, and appeared to contribute to reduced competitive ability of $C$. greggii seedlings compared to chamise seedlings (Mills 1985). In a second study (Moreno and Oechel 1992), 51.4\% of C. Greggii seedlings appeared to be infested, and infested seedlings suffered significantly higher mortality during the second season after fire than uninfested seedlings. Seedling mortality in the second season was $30.0 \%$, and of those that died, the ratio of infested to uninfested shrubs was $3: 1$. 
Psyllid abundance, like that of other herbivorous insects, may be affected by elevated atmospheric $\mathrm{CO}_{2}$ levels (Bezemer and Jones 1998, Coviella and Trumble 1999). Although there have been few studies of $\mathrm{CO}_{2}$ effects on insects and mites that feed on cell contents like psyllids, food consumption and population densities increased with elevated $\mathrm{CO}_{2}$ in the two studies where whole-cell feeders were studied (reviewed by Bezemer and Jones 1998).

Hostplant density is another factor that might affect psyllid density. In addition to basic nutritional quality effects, high densities of host plants, or more resources, should allow greater population densities of psyllids to be maintained at any given site. Since evidence suggests that elevated $\mathrm{CO}_{2}$ may beneficially affect plant populations via increased water use efficiency and growth rates (Schortmeyer et al. 1999, Thomas et al. 2000), this could also lead to further enhanced psyllid population densities. However, if psyllid density continues to increase under elevated $\mathrm{CO}_{2}$, higher herbivore load might cause increased C. greggii mortality (Mills 1985, Moreno and Oechel 1992). Until the relative effects of such complex interactions are better understood, we cannot predict the ultimate effects of elevated $\mathrm{CO}_{2}$ on this shrub. The major objectives of this study are to compare densities of $C$. greggii shrubs growing under ambient (360 ppmv) and elevated (550 ppmv) atmospheric $\mathrm{CO}_{2}$ levels, and identify possible effects of elevated $\mathrm{CO}_{2}$ and shrub densities on psyllid densities.

\section{Methods}

\section{Psyllid Abundance}

To address the objectives, psyllid abundance was compared in $15 \mathrm{~m}$ diameter open plots that differed in atmospheric $\mathrm{CO}_{2}$ concentrations and C. greggii densities. These plots 
were located within the 5-year post-burn chamise chaparral community at San Diego State University's Sky Oaks Biological Field Station described in Chapter 1. In June 1999, all live $C$. greggii shrubs were counted in the FACE ring plot (550 ppmv $\mathrm{CO}_{2} ; 15 \mathrm{~m}$ diameter) and 2 adjacent ambient $\mathrm{CO}_{2}$ plots (360 ppmv $\mathrm{CO}_{2} ; 15 \mathrm{~m}$ diameter), including one with a similar ring structure. Ambient plots were located approximately $10 \mathrm{~m}$ north (ambient north plot), and $20 \mathrm{~m}$ south (ambient control ring) of the FACE ring.

Psyllid densities were measured for two seasons using whitefly trap cards (Surefire $\subset$ brand) over 24 hours periods. In June 1999, traps were placed the center of 12 haphazardly selected $C$. greggii shrubs per plot located in the FACE ring and one ambient plot. In May 2000, 16 shrubs per plot were selected for trap placement in the control ring (ambient $\left[\mathrm{CO}_{2}\right]$ ), the FACE ring (high $\left[\mathrm{CO}_{2}\right]$ ), and the north plot (ambient $\left[\mathrm{CO}_{2}\right]$ ). The three plots varied in C. greggii density, with the north plot density > the FACE ring density $>$ the control ring density. Shrubs in the low-density plot appeared to be smaller than those in the high density plot, based on visual inspection. Although location of shrubs was haphazardly selected, shrubs with minimum dimensions of $30 \mathrm{~cm}$ at the widest diameter and $25 \mathrm{~cm}$ at the widest diameter at a right angle to the first were selected for trap placement. Shrub dimensions were then used to calculate psyllid density per plant volume. Unfortunately, shrub measurements were not collected in 2000, so psyllid densities could not be adjusted for differences in shrub volume in that year.

\section{Data Analysis}

Ellipsoidal volume of shrubs was estimated using the oblate spheroid formula: $4 / 3 \mathrm{p}(a / 2)^{2}(b / 2)$, where $a$ is the widest diameter, and $b$ is the widest diameter at right angles to it. To achieve a normal distribution, psyllid per shrub were transformed using 
$\log (\mathrm{x}+1)$ prior to analyses. To compare number of psyllids collected per shrub in FACE vs. the ambient north plot in 1999, a Student's t-test was used. To compare psyllid densities among FACE and the two ambient plots in 2000, an ANOVA was performed, followed by a Tukey's multiple-comparison post-hoc test when significant differences among means were detected (SYSTAT version 8, copyright SPSS 1998). Two types of psyllids were identified from traps in 2000: a species of psyllid that appeared to feed exclusively on $C$. greggii (hereafter referred to as lilac psyllids; probably responsible for much of the $C$. greggii damage observed in earlier studies), and all other psyllid species. Analyses of psyllid densities in 2000 were run on each psyllid group seperately and results compared.

\section{Results}

C. greggii densities were highly variable among sites. The mean density of $C$. greggi in the FACE plot (229 shrubs; 550 ppm $\mathrm{CO}_{2}$ ) was intermediate to the mean density of the ambient plots. (north plot $=443$ and control ring $=76$ shrubs The ambient north plot had approximately twice as many $C$. greggii shrubs as the FACE plot and the ambient control ring plot had only about $30 \%$ of the density found in the FACE plot (Table 1).

In both 1999 and 2000, mean psyllid densities per shrub were higher (but not statistically significant) on shrubs growing in the FACE plot compared to ambient control plots (Table 1). In June 1999, the mean density of psyllids collected per C.greggii shrub was higher in the FACE compared to the ambient north plot (Table $1 ; \mathrm{t}=1.88, \mathrm{P}=0.068$ ), and when values were adjusted for plant volume using psyllids $/ \mathrm{cm}^{3}$ ellipsoidal shrub volume, the difference between means became significant (Table $1 ; \mathrm{t}=3.42, \mathrm{P}<0.01)$. In 2000 the density of lilac psyllids per shrub in the FACE was higher than in the control ring plot but not significantly higher than in the ambient north plot (Figure 1; ANOVA F = 5.69, 
$\mathrm{P}<0.01$; post-hoc test: FACE vs. control ring, $\mathrm{P}<0.01$, FACE vs. north plot, $\mathrm{P}=0.77$, control ring vs. north plot, $\mathrm{P}=0.04)$. In 2000, mean densities of psyllid species other than lilac psyllids also tended to be highest in the FACE plot, but were not significantly different from either ambient plot (Figure 2; ANOVA F = 1.22, $\mathrm{P}=0.31$ ).

Table 1. Ceanothus greggii and psyllid densities in $15 \mathrm{~m}$ diameter post-burn chamise chaparral ring plots at Sky Oaks Biological Field Station. The FACE ring was an elevated $\mathrm{CO}_{2}$ treatment plot (mean $\mathrm{CO}_{2}$ concentration $=550 \mathrm{ppmv}$ ), other plots were ambient $\mathrm{CO}_{2}$ concentrations (approximately 360 ppmv). Psyllid densities are presented as means with standard deviations in parentheses. $\mathrm{N}=12$ traps per $15 \mathrm{~m}$ diameter plot for 1999 and 16 traps per plot for 2000. Data were log transformed for analyses, but non-transformed values are also given below. Significantly different values are represented by different subscripts.

FACE ring ambient north plot ambient control ring (Elevated $\mathrm{CO}_{2}$ )

C. greggii shrubs/plot $229 \quad 443$

Psyllids/

$0.043(0.028)^{\mathrm{a}} \quad 0.012(0.013)^{\mathrm{b}}$

ellipsoidal shrub

volume $\mathrm{dm}^{3}$ (1999)

Psyllids/shrub

$12.58(5.96) \quad 8.33(4.48)$

1999

All psyllids 


\section{Discussion}

Our hypothesis that psyllid density would increase with elevated $\mathrm{CO}_{2}$ was supported in 1999 by the difference in densities between the FACE ring and the north plot when shrub volume was considered (Table 1). If the effect was similar to that in 1999, a similar adjustment to data collected in 2000 might have produced a greater difference in psylllid densities among elevated and ambient $\mathrm{CO}_{2}$ treatments (Table 1).

This study demonstrated that, at least in some cases, psyllid density increased with elevated $\mathrm{CO}_{2}$, and apparently also with increasing plant density. Results suggested that $\mathrm{CO}_{2}$ level and plant density may produce additive effects. That is, both variables might be positively correlated with psyllid density for different. If plant density explains part of the difference in psyllid densities among plots, had plant densities been equal, psyllid densities probably would have been even higher in the elevated $\mathrm{CO}_{2} \mathrm{FACE}$ plot compared to the ambient north plot. Our hypotheses that higher hostplant density should correspond with higher psyllid density was supported by the result that lilac psyllid density was almost double under 6 times greater plant density in the ambient $\mathrm{N}$ plot compared to the control ring plot (Table 1). The heterogeneous distribution of C. greggii among the $15 \mathrm{~m}$ diameter plots (Table 1) indicates that other environmental factors such as soil moisture and nutrients 
or random events affected post-fire seedling establishment and survival more strongly than atmospheric $\mathrm{CO}_{2}$ concentration.

Elevated $\mathrm{CO}_{2}$ appears to have affected psyllids (Fig. 1) differently in this study than it did most fluid-feeding herbivores in the $\mathrm{CO}_{2} \mathrm{LT}$ chambers (data presented in Chapter 1). Although not statistically significant, total fluid feeding herbivore abundance was lower under elevated $\mathrm{CO}_{2}$ in the $\mathrm{CO}_{2} \mathrm{LT}$ chambers and FACE ring in 1998, but this trend may have been weakened by inclusion of whole-cell feeding psyllids. The difference between the Chapter 1 fluid-feeder results, and these results for psyllids in this study may be explained by several factors. Perhaps cell content feeding resulted in different physiological responses than phloem feeding and similar folivores, (abundance data presented in Chapter 1). It is also possible that the apparent psyllid population increase with elevated $\mathrm{CO}_{2}$ may have been mediated by the physiology of C.greggii.

Mills (1985) hypothesized that higher foliar water content of C. greggii could account for higher insect density and damage compared to Adenostoma fasciculatum. Although it has not been consistently observed, foliar water content increased with elevated $\mathrm{CO}_{2}$ in soybeans and limabeans, and may result from increased water use efficiency when water availability is limited (Lincoln et al. 1993). Therefore, higher water content of foliage may partly explain higher psyllid densities found in this study under elevated $\mathrm{CO}_{2}$. Another contributing factor may be that $C$. greggii are nitrogen-fixing shrubs, as decreased $\mathrm{N}$ content is characteristic of elevated $\mathrm{CO}_{2}$-grown foliage (Lincoln et al. 1993, Bezemer and Jones 1998) and might limit herbivore growth to a greater extent on other hostplant species. Nitrogen-fixing hostplants were one explanation for Goverde et al. 's (1999) positive results with common blue butterfly larvae. Thus, the apparent difference between 
the response of psyllids in this study compared to all fluid-feeding herbivores in the chambers could have been due to differences among hostplants, insect feeding methods, or both.

Higher psyllid density per shrub volume in the FACE ring in 1999, and a similar (but not significant) pattern in 2000 indicates that psyllid densities may increase under future elevated atmospheric $\mathrm{CO}_{2}$ levels, leading to increased psyllid infestations of $C$. greggii. Increased population densities are also in general agreement with previous wholecell feeder results (reviewed by Bezemer and Jones 1998). If psyllid densities do increase, C. greggii density could be reduced in the chamise chaparral community (Mills 1985, Moreno and Oechel 1992). While this conclusion is limited to one type of herbivore and one shrub species, $C$. greggii is a co-dominant member of this ecosystem, and its reduction should have major implications for ecosystem dynamics.

\section{Literature Cited}

Bezemer, T.J., T.H. Jones, and K.J. Knight. 1998. Long-term effects of elevated $\mathrm{CO}_{2}$ and temperature on populations of the peach potato aphid Myzus persicae and its parasitoid Aphidius matricariae. Oecologia 116: 128-135.

Coviella, C.E. and J.T. Trumble. 1999. Effects of elevated atmospheric carbon dioxide on insect-plant interactions. Conservation Biology 13: 700-712.

Goverde, M., A. Bazin, J.A. Shykoff, and A. Erhardt. 1999. Influence of leaf chemistry of Lotus corniculatus (Fabacae) on larval development of Polymmatus icarus (Lepidoptera, Lycaenidae): effects of elevated $\mathrm{CO}_{2}$ and plant genotype. Functional Ecology 13: 801-810.

Lincoln, D.E., E.D. Fajer, and R.H. Johnson. 1993. Plant-insect herbivore interactions in elevated $\mathrm{CO}_{2}$ environments. Trends in Ecology and Evolution 8: 64-68.

Mills, J.N. 1985. Herbivores and early postfire succession in southern California chaparral. PhD Dissertation, University of California, Davis and San Diego State University, San Diego, California, USA.

Moreno, J.M. and W.C. Oechel. 1992. Factors controlling postfire seedling establishment in southern California chaparral. Oecologia 90: 50-60.

Schortemeyer, M., O.K. Atkin, N. McFarlane, and J.R. Evans. 1999. The impact of elevated $\mathrm{CO}_{2}$ and nitrate supply on growth, biomass allocation, nitrogen partitioning, 
and $\mathrm{N}_{2}$ fixation of Acacia melanoxylon. Australian Journal of Plant Physiology 26: 737747.

Thomas, R.B., M.A. Bashkin, and D.D. Richter. 2000. Nitrogen inhibition of nodulation and $\mathrm{N}_{2}$ fixation of a tropical $\mathrm{N}_{2}$-fixing tree (Gliricidia sepium) grown in elevated atmospheric $\mathrm{CO}_{2}$. New Phytologist 145: 233-243. 


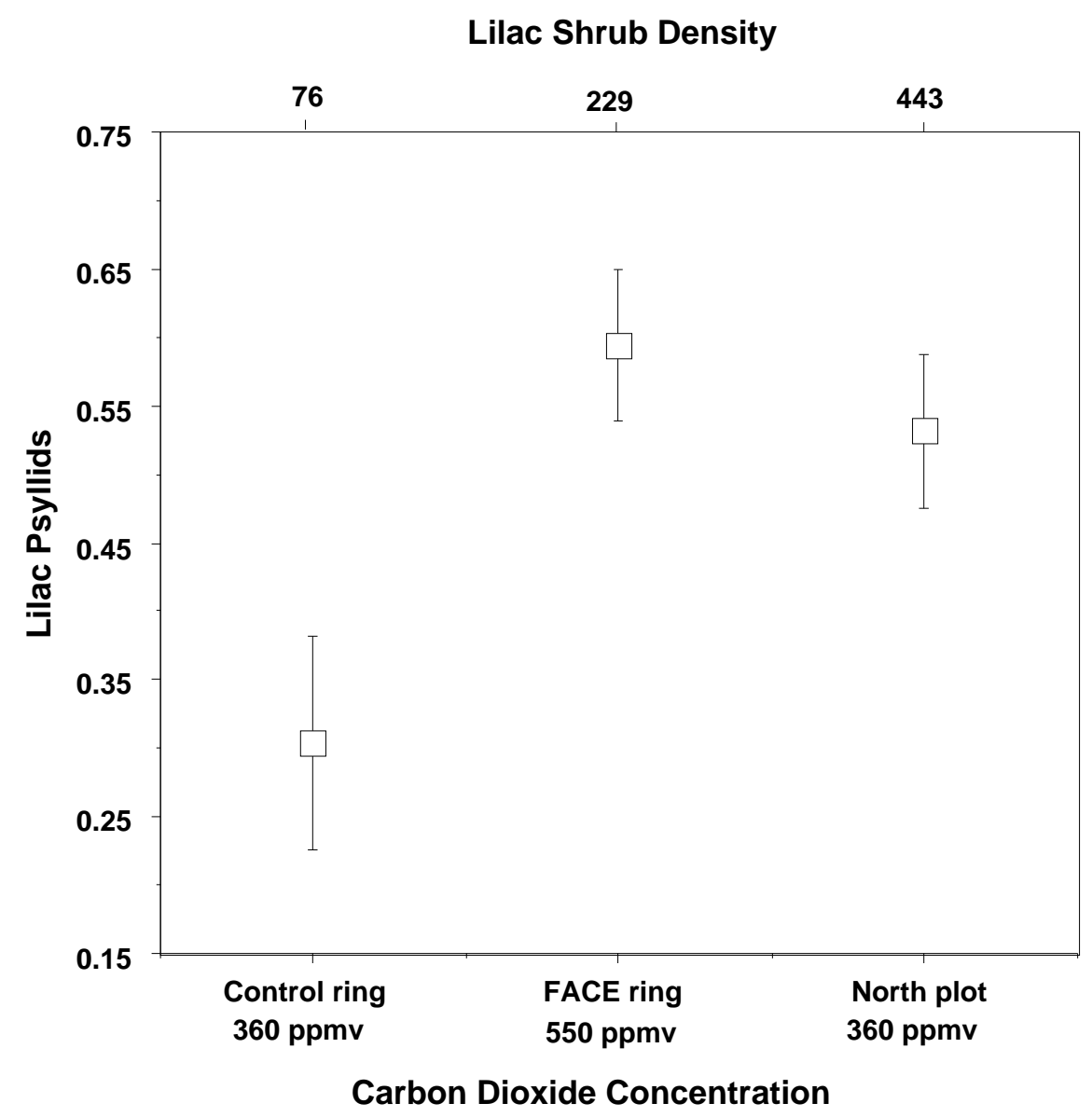

Figure 1. Psyllid abundance per trap in 2000 (log transformed) of the species observed feeding specifically on Ceanothus greggii. Lilac shrub density refers to Ceanothus greggii shrubs per $15 \mathrm{~m}$-diameter ring plot. 


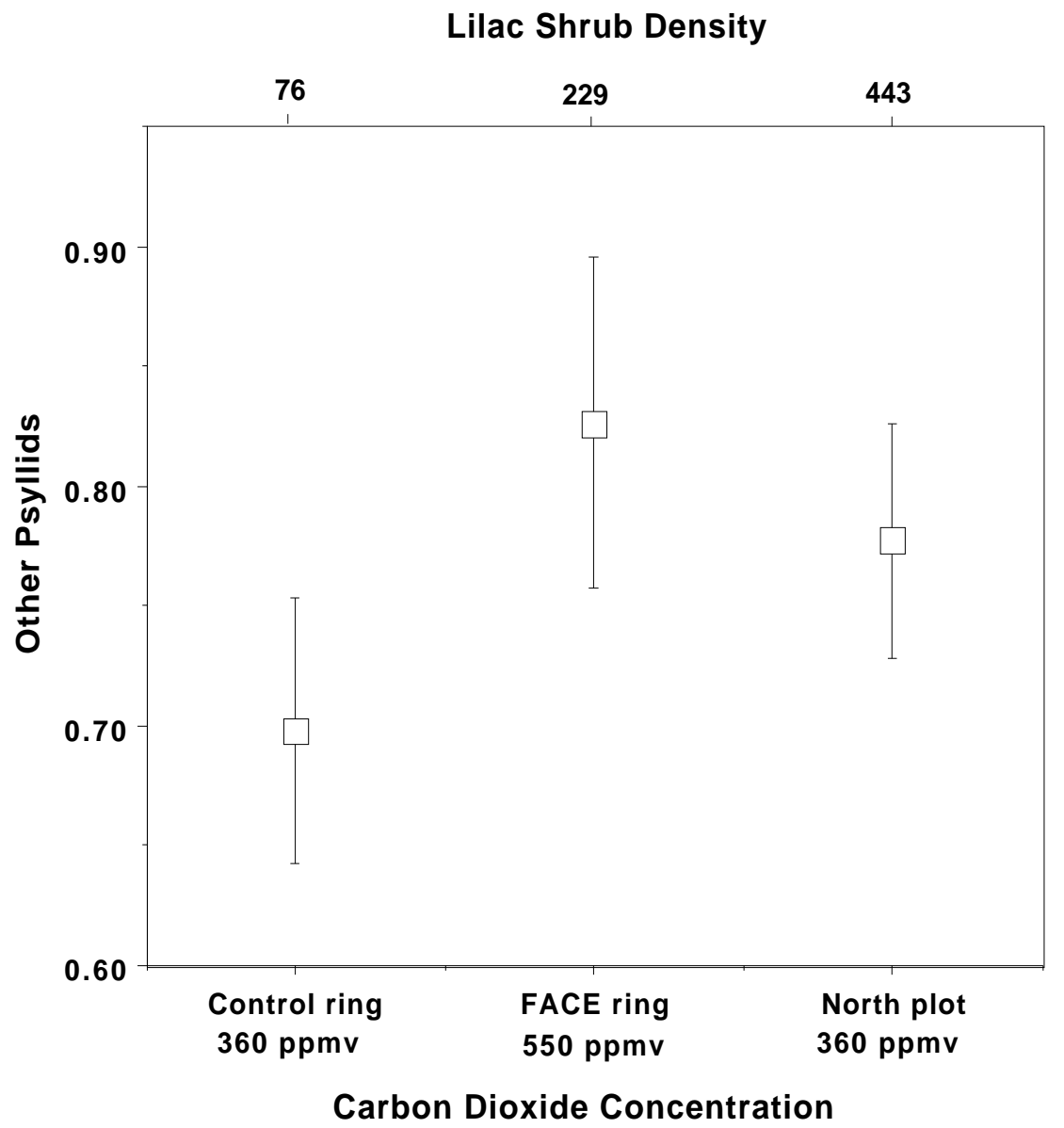

Figure 2. Psyllid abundance per trapin 2000 (log transformed) for all species other than the one known to feed specifically on Ceanothus greggii. Lilac shrub density refers to Ceanothus greggii shrubs per $15 \mathrm{~m}$ diameter ring plot. 
Effects of lifelong $\left[\mathrm{CO}_{2}\right]$ enrichment on carboxylation and light utilization of Quercus pubescens Willd. examined with gas exchange, biochemistry and optical techniques

C.D. Stylinski*, W.C. Oechel*, J.A. Gamon**, D.T. Tissue $\uparrow$, F. Miglietta $\uparrow \dagger$, and A. Raschi $\dagger \dagger$

*San Diego State University, San Diego, CA, 92182 USA

**California State University, Los Angeles, CA, 90032 USA

$\dagger$ Texas Tech University, Lubbock, TX, 79409-3131

$\dagger \dagger$ Institute of Environmental Analysis and Remote Sensing for Agriculture, P. le delle Cascine 18, 1-50144 Firenze, Italia

\section{ABSTRACT}

Lifelong exposure to elevated concentrations of atmospheric $\mathrm{CO}_{2}$ may enhance carbon assimilation of trees with unlimited rooting volume and consequently may reduce requirements for photoprotective pigments. In early summer we examined effects of elevated $\left[\mathrm{CO}_{2}\right]$ on carboxylation and light utilization of mature Quercus pubescens trees growing under chronic $\left[\mathrm{CO}_{2}\right]$ enrichment at two $\mathrm{CO}_{2}$ springs and control sites in Italy. Net photosynthesis was enhanced 36-77\%. There was no evidence of photosynthetic downregulation early in the growing season when sink demand presumably was greatest. Specifically, maximum assimilation at saturating $\left[\mathrm{CO}_{2}\right]$, electron transport capacity, and Rubisco content, activity and carboxylation capacity were not significantly different in trees growing at the $\mathrm{CO}_{2}$ springs and their respective control sites. Foliar biochemical content, NDVI (leaf reflectance index of chlorophyll pigments), and photochemical efficiency of 
PSII ( $\Delta \mathrm{F} / \mathrm{Fm}$ ') also were not significantly affected by $\left[\mathrm{CO}_{2}\right]$ enrichment except that starch content and $\Delta \mathrm{F} / \mathrm{Fm}$ ' tended to be higher at one spring ( $42 \%$ and $15 \%$, respectively). Contrary to expectation, prolonged elevation of $\left[\mathrm{CO}_{2}\right]$ did not reduce xanthophyll cycle pigment pools or alter midday PRI values (leaf reflectance index of xanthophyll cycle pigments), despite the enhancement of carbon assimilation. However, both these pigments and PRI were well correlated with electron transport capacity.

Key-words: $\mathrm{CO}_{2}$ springs, Photochemical Reflectance Index, Quercus pubescens, xanthophyll cycle pigments

\section{INTRODUCTION}

Trees account for up to $70 \%$ of terrestrial atmospheric carbon fixation (Meyer \& Turner 1992; Melilo et al. 1993) and thus may have a significant impact on rapidly rising concentrations of atmospheric carbon dioxide (Harmon, Ferrell \& Franklin 1990; Walker \& Kasting 1992). Carbon uptake is often stimulated by short-term exposure to elevated $\left[\mathrm{CO}_{2}\right]$; however, the photosynthetic response of trees over longer time scales varies with carbon sink demand (Griffin \& Seemann 1996). When sink demand is low due to genetic or environmental limitations, photosynthetic capacity is often decreased, or downregulated, through biochemical, physiological and morphological feedback mechanisms (Long \& Drake 1991; Stitt 1991; Sage 1994; Griffin \& Seemann 1996). Photosynthetic downregulation has been observed for older foliage and late in the growing season (e.g., Mousseau 1993; Tissue, Thomas \& Strain 1993; Lewis, Tissue \& Strain 1996; Rey \& Jarvis 1998; Spunda et al. 1998; Turnbull et al. 1998; Tissue, Griffin \& Ball 1999) but is seldom reported for current-year foliage and when resources are readily available (e.g., 
Idso, Kimball \& Allen 1991; Gunderson, Norby \& Wullschleger 1993; Idso et al. 1995; Hogan et al. 1997; Turnbull et al. 1998). However, these and most other $\left[\mathrm{CO}_{2}\right]$ enrichment studies were conducted on seedlings or young trees under controlled conditions and with less than ten years of $\mathrm{CO}_{2}$ fumigation (Saxe, Ellsworth \& Heath 1998; Norby et al. 1999; Medlyn et al. 1999). Thus they may not describe the physiological responses of more mature trees exposed to chronic $\left[\mathrm{CO}_{2}\right]$ enrichment and natural fluctuations in other resources (Eamus \& Jarvis 1989; Lee \& Jarvis 1995).

Carbon assimilation is a primary sink for light energy captured by photosynthetic pigments. If carbon assimilation rates are increased with long-term $\left[\mathrm{CO}_{2}\right]$ enrichment (and irradiance is held constant), more captured light energy will be utilized photochemically, and photochemical efficiency of photosystem two (PSII) may be increased. To the extent that PSII photochemical efficiency is linked to carbon assimilation, we might expect susceptibility to photoinhibitory damage and investment in photoprotective xanthophyll cycle pigments to be reduced with long-term $\left[\mathrm{CO}_{2}\right]$ enrichment. Xanthophyll cycle pigments accept excess light energy from excited chlorophyll molecules of PSII and dissipate it harmlessly as heat (Frank et al. 1994).

Only a few studies have linked PSII photochemical efficiency and xanthophyll cycle pigment pools with carbon assimilation, particularly in the context of elevated $\left[\mathrm{CO}_{2}\right]$. Under full midday sunlight, leaves with low rates of photosynthesis had greater total and/or de-epoxidized (photoprotective) pools of xanthophyll cycle pigment than leaves with higher photosynthetic rates (Thayer \& Björkman 1990; Gamon, Serrano \& Surfus 1997). Barták, Nijs \& Impens (1996) and Spunda et al. (1998) reported that simultaneous measurements 
of PSII photochemical efficiency and carbon assimilation varied together with both shortterm (minutes) and long-term (six months and four seasons) exposure to $\left[\mathrm{CO}_{2}\right]$ enrichment. PSII photochemical efficiency and an optical estimate of xanthophyll cycle pigment activity were also linked with carbon assimilation of plants briefly exposed to sub-ambient $\mathrm{CO}_{2}$ concentrations (Gamon et al. 1997). However, we know of only one investigation that examined the long-term effects of $\left[\mathrm{CO}_{2}\right]$ enrichment on these photoprotective pigments (Hogan et al. 1997). This investigation reported no elevated-[ $\left[\mathrm{CO}_{2}\right]$ effect on content and activity of xanthophyll cycle pigments of tree seedlings.

The goal of our study was to examine the effect of long-term $\left[\mathrm{CO}_{2}\right]$ enrichment on foliar carbon assimilation and photoprotective pigment pools of mature Quercus pubescens Willd. trees growing naturally at $\mathrm{CO}_{2}$ springs in central Italy. Carbon dioxide springs release $\mathrm{CO}_{2}$ from geological sources (Miglietta et al. 1995) and present a rare opportunity to study in situ the long-term adjustment of mature long-lived species to lifelong atmospheric $\left[\mathrm{CO}_{2}\right]$ enrichment. For example, a recent study in Iceland reported significant physiological downregulation of a perennial grass species growing near a $\mathrm{CO}_{2}$ spring thought to be active for more than 100 years (Cook et al. 1998). However, $\mathrm{CO}_{2}$ springs suffer from high spatial and temporal variability in $\mathrm{CO}_{2}$ concentration, presence of confounding environmental factors such as sulfur emission, and lack of true replicates (Miglietta et al. 1993a). We addressed the replication problem by examining the response of $\mathrm{Q}$. pubescens trees at two $\mathrm{CO}_{2}$ springs and nearby control sites. Additionally, although both springs in this study produce low levels of $\mathrm{H}_{2} \mathrm{~S}$ and $\mathrm{SO}_{2}(11-22 \mathrm{ppb}$ and 2-16 ppb, respectively; Schulte et al. 1998), no damage was apparent at either site or at another spring 
with more than 100 times greater concentration of these trace gases (Badiani et al. 1993; Miglietta et al. 1993b).

To investigate elevated-[CO $\left.\mathrm{CO}_{2}\right]$ effects on carboxylation and light utilization of $\underline{Q}$. pubescens, we examined gas exchange rates, a biochemical model of photosynthesis, chlorophyll fluorescence of PSII, and foliar biochemical composition of trees at the $\mathrm{CO}_{2}$ springs and control sites. Additionally, we examined the use of two leaf reflectance indices - the Photochemical Reflectance Index (PRI; a measure of xanthophyll cycle pigment activity; Peñuelas, Filella \& Gamon 1995; Gamon et al. 1997; Peñuelas et al. 1997; Gamon \& Surfus 1999) and a modified Normalized Difference Vegetation Index (NDVI; a measure of chlorophyll content; Gitelson \& Merzylak 1994; Gamon \& Surfus 1999) - to detect variations in pigment content and carbon assimilation. These reflectance indices are of particular interest because they can be measured quickly, non-destructively, and in situ and may be useful for scaling the physiological response to $\left[\mathrm{CO}_{2}\right]$ enrichment from leaf to canopy to stand levels (cf. Gamon \& Qiu 1999).

\section{MATERIALS AND METHODS}

Site and species description

Measurements were made on mature $\underline{Q}$. pubescens trees growing in forests near two $\mathrm{CO}_{2}$ springs (Bossoleto and Laiatico) in Tuscany, Italy. Trees at these springs were coppiced 40-50 years ago and have likely been exposed throughout their lives to $\left[\mathrm{CO}_{2}\right]$ enrichment (Miglietta et al. 1993a; Hättenschwiler et al. 1997a). The Bossoleto spring has been described by Körner \& Miglietta (1994), van Gardingen et al. (1995) and Schulte et al. (1998). This spring is near Siena, Italy $\left(43^{\circ} 17^{\prime} \mathrm{N}, 11^{\circ} 36^{\prime} \mathrm{E}\right)$ and is characterized by a Mediterranean forest dominated by $\mathrm{Q}$. $\mathrm{ilex} \mathrm{L}$. and $\mathrm{Q}$. pubescens. $\mathrm{CO}_{2}$ is discharged from 
several vents that occur in a large circular crater (approximately $80 \mathrm{~m}$ circumference, $20 \mathrm{~m}$ deep). Quercus trees grow on the steep surrounding slopes. A control site (Bossoleto control) with similar species, soil composition and slope orientation (A. Raschi, unpublished data) was located $4 \mathrm{~km}$ northeast of the spring. The Laiatico spring is approximately $70 \mathrm{~km}$ east of the Bossoleto spring. It is within the village of Laiatico near the city of Volterra, Italy ( $\left.43^{\circ} 26^{\prime} \mathrm{N}, 10^{\circ} 42^{\prime} \mathrm{E}\right)$ and has been described in Hättenschwiler et al. (1997a) and Schulte et al. (1998). A large vent and several neighboring small ones occur along a stream on a gentle north-facing slope. $\mathrm{CO}_{2}$ flows downslope due to the topography and northeast tending winds (C. Stylinski, unpublished data). This spring is covered by a Mediterranean forest dominated in the upper canopy by $\underline{Q}$. ilex, $\underline{Q}$. pubescens, Q. cerris L., Fraxinus ornus L., and Arbutus unedo L. A control site (Laiatico control) was located in an area with similar species, soil composition and slope orientation (Raiesi 1998a, b) approximately $150 \mathrm{~m}$ southeast and upslope from the vent.

Atmospheric $\left[\mathrm{CO}_{2}\right]$ has been measured at both springs with infrared gas analyzers and $\Delta^{14} \mathrm{C}$ analysis (long-term average of ${ }^{14} \mathrm{C}$-depleted $\mathrm{CO}_{2}$ from geological sources that is incorporated into plant tissues). Data from these methods agree and indicate that average daytime atmospheric $\left[\mathrm{CO}_{2}\right]$ in the study areas is 590 to $700 \mu \mathrm{mol} \mathrm{mol}{ }^{-1}$ with short-term variations between 450 and $800 \mu \mathrm{mol} \mathrm{mol}^{-1}$ (Körner \& Miglietta 1994; Hättenschwiler et al. 1997a; Schulze et al. 1998). Using a portable infrared gas analyzer (IRGA, EGM-1, PP Systems; Hitchin, UK) placed near the study trees, we monitored atmospheric $\left[\mathrm{CO}_{2}\right]$ at the spring and control sites every minute from midmorning (starting between 9:00 and 11:00 a.m.) until midafternoon (ending between 4:00 to 4:30 p.m.) concurrently with physiological measurements. 
Physiological measurements were made on three Laiatico and four Bossoleto $\underline{Q}$. pubescens trees of similar size growing near each $\mathrm{CO}_{2}$ spring and control site between late May and mid June 1997. Some measurements were also made on an additional tree at the Bossoleto spring site and control site. Q. pubescens is a winter-deciduous species that can produce multiple leaf flushes. Leaf ontogeny and age can affect physiological responses to elevated $\left[\mathrm{CO}_{2}\right]$ (Griffin \& Seemann 1996; Turnbull et al. 1998). To minimize these effects, measurements of the oldest cohort were made on leaves approximately 1 to $1.5 \mathrm{~m}$ above the ground.

Photosynthesis, PSII photochemical efficiency of light-adapted leaves, and activity of xanthophyll cycle pigments are strongly influenced by incident irradiance. Consequently, we attempted to standardize light conditions by selecting leaves on the outer part of the tree crown that received photosynthetic photon flux density (PPFD) greater than $1500 \mu \mathrm{mol} \mathrm{m}{ }^{-2}$ $\sec ^{-1}$ during our measurement period. Incident PPFD, fluorescence, reflectance, and tissue samples for pigment and ribulose 1,5-bisphosphate carboxylase/oxygenase (Rubisco) analyses were collected from the same subset of leaves. Each leaf was measured and harvested within several minutes, and sampling of each tree was completed within an hour. Sampling at each study site was conducted over several days. Average incident PPFD $\left( \pm \mathrm{SEM} ; \mu \mathrm{mol} \mathrm{m} \mathrm{m}^{-2} \mathrm{~s}^{-1}\right)$ for trees at each site was as follows: $1863 \pm 43$ and $1830 \pm 40$ (Bossoleto spring and control, respectively) and 1631 \pm 17 and 1882 \pm 62 (Laiatico spring and control, respectively). Gas exchange measurements required more time (10 to 30 minutes) than these techniques (one to several minutes) and could not be measured concurrently with optical measurements. Instead, rates of gas exchange were collected within one to two 
weeks of optical measurements under saturating light $\left(2000 \mu \mathrm{mol} \mathrm{m} \mathrm{m}^{-2} \mathrm{sec}^{-1}\right.$ PPFD) using an internal light source.

\section{Gas exchange}

Curves of carbon assimilation response to internal $\left[\mathrm{CO}_{2}\right]\left(A / C_{\mathrm{i}}\right)$ were measured in situ with a gas exchange system (Li-Cor model 6400; Lincoln, NE) equipped with a $\mathrm{CO}_{2}$ control module. Measurements were made on one to two leaves of each tree under steadystate conditions and at a range of external $\left[\mathrm{CO}_{2}\right]$ between 50 and $2200 \mu \mathrm{mol} \mathrm{mol}^{-1}$. Data were recorded after leaves acclimated to each $\left[\mathrm{CO}_{2}\right]$ and when the coefficient of variation between the sample and reference $\mathrm{CO}_{2}$ analyzers was $<3 \%$ ( 5 minutes on average). Temperature was maintained close to ambient air values $\left(27-30{ }^{\circ} \mathrm{C}\right)$ with Peltier thermoelectric coolers. Leaf water vapor pressure deficit was maintained with desiccant between 2.1-3.7 $\mathrm{kPa}$, and the range was less than $1 \mathrm{kPa}$ for each response curve.

Using the $A / C_{\mathrm{i}}$ curves and a biochemical model of photosynthesis, we calculated parameters that potentially limit photosynthesis under elevated $\left[\mathrm{CO}_{2}\right]$. We used Photosyn Assistant software (v 1.1, Dundee Scientific; Dundee, Scotland, UK) that applies the biochemical model described by von Caemmerer and Farquhar (1981), Sharkey (1985), Harley and Sharkey (1991), and Harley et al. (1992). This model calculates maximum carboxylation rate by Rubisco $\left(V_{\text {cmax }}\right)$ and ribulose 1,5-bisphophate (RuBP) regeneration capacity regulated by electron transport under saturating light $\left(J_{\max }\right)$. We did not report the rate of triose phosphate utilization by starch and sucrose synthesis because our $A / C_{\mathrm{i}}$ curves did not appear to saturate (Wullschleger 1993). Maximum carbon assimilation $\left(A_{\max }\right)$ was 
determined from $A / C_{\mathrm{i}}$ curves using net assimilation rates measured at $2200 \mu \mathrm{mol} \mathrm{mol}{ }^{-1}$ $\left[\mathrm{CO}_{2}\right]$.

At the Bossoleto control and spring sites only, carbon assimilation and stomatal conductance were also measured on four to five leaves per tree at external $\left[\mathrm{CO}_{2}\right]$ of 350 and $600 \mu \mathrm{mol} \mathrm{mol} \mathrm{m}^{-1}$ and at saturating PPFD $\left(2000 \mu \mathrm{mol} \mathrm{m} \mathrm{m}^{-2} \mathrm{sec}^{-1}\right)$. These reciprocal measurements were used at the control and spring sites to determine net carbon assimilation rates at approximate growth $\left[\mathrm{CO}_{2}\right]\left(350\right.$ and $600 \mu \mathrm{mol} \mathrm{mol}{ }^{-1}$, respectively). At the Laiatico control and spring sites, carbon assimilation and conductance at growth $\left[\mathrm{CO}_{2}\right]$ were determined from $A / C_{\mathrm{i}}$ curves using measurements at 350 or $600 \mu \mathrm{mol} \mathrm{mol}{ }^{-1}$, respectively.

\section{Reflectance and fluorescence}

As described above, five to ten leaves were selected from each tree at both study sites for reflectance and fluorescence measurements. Leaf reflectance was measured on the adaxial side with a portable reflectometer (Unispec, PP Systems; Haverhill, MA). The reflectometer consists of a leaf clamp and bifurcated fiber optic cable attached to a light source and to a narrow-waveband spectroradiometer (Gamon \& Surfus 1999). Leaf reflectance was determined from leaf radiance divided by radiance of a $99 \%$-reflective white standard (Spectralon, Labsphere Inc.; North Dutton, NH). Spectral (wavelength) calibration was checked daily with a mercury-argon lamp and remained stable over the sampling period. The Photochemical Reflectance Index (PRI) was calculated as $\left(R_{531}-R_{570}\right)$ / $\left(R_{531}+R_{570}\right)$, where $R_{531}$ and $R_{570}$ are reflectance of the xanthophyll and reference wavebands, respectively (Gamon et al. 1997). The reference waveband largely normalizes for reflectance variations due to chloroplast movement and content of other pigments. The 
Normalized Difference Reflectance Index (NDVI) was calculated as $\left(R_{750}-R_{705}\right) /\left(R_{750}+\right.$ $\left.R_{705}\right)$, where $R_{750}$ and $R_{705}$ are reflectance of the near-infrared region and the edge of red (chlorophyll) absorption wavebands, respectively (Gitelson \& Merzylak 1994; Gamon \& Surfus 1999).

Chlorophyll fluorescence of PSII was recorded immediately after reflectance measurements on the same portion of the leaf using a modulated fluorometer (OS-500, OptiScience; Tyngsboro, MA). Photochemical efficiency of PSII was calculated as $\Delta \mathrm{F} / \mathrm{Fm}$ ' or $(\mathrm{Fm}$ ' $-\mathrm{F})$ / Fm', where Fm' is the maximal fluorescence during light saturation and $\mathrm{F}$ is the level of steady-state fluorescence of light-adapted leaves (Genty, Briantais \& Baker 1989).

\section{Foliar chemical analyses}

At the Bossoleto spring and control sites only, disks were punched from leaves measured for reflectance and fluorescence (one leaf per tree). Disks were immediately immersed in liquid nitrogen and stored at $-80^{\circ} \mathrm{C}$ until biochemical analysis. Chlorophyll, carotenoid and xanthophyll cycle pigments were extracted and analyzed with highperformance liquid chromatography (HPLC; model LC-10AS with detector SPD-10AV, Shimadzu; Kyoto, Japan) according to Thayer \& Björkman (1990). Xanthophyll cycle pigments were expressed as total pool size (violaxanthin + antheraxanthin + zeaxanthin) and pool size in the de-epoxidized state $(0.5 *$ antheraxanthin + zeaxanthin) / (violaxanthin + antheraxanthin + zeaxanthin).

From each tree, five of the leaves measured optically were also harvested, immediately frozen and stored at $-80^{\circ} \mathrm{C}$ for Rubisco analysis. Content, total activity (fully 
activated) and activation state (ratio of initial to total activity) of Rubisco were determined as described by Tissue et al. (1993).

Additional leaves were collected from each tree after reflectance and fluorescence measurements at the Bossoleto site for content of total nitrogen, total carbon, sugar and starch. Within three hours of harvesting, leaves were dried in a microwave oven for five minutes (Körner \& Miglietta 1994). Prior to chemical analysis, the leaves were redried in a conventional oven at $70^{\circ} \mathrm{C}$ to a constant mass and ground in a Wiley mill with 60-mesh screen. Content of total nitrogen and of total carbon were determined with an elemental analyzer (NSC 2500, Fison Instruments, Milan, Italy). Sugar content and starch content were determined as described by Gaines (1973). Nonstructural carbohydrates (TNC) were calculated as the sum of sugar and starch.

\section{Statistical Analysis}

Student's $t$-tests for populations with unequal variance were used to compare spring and control site variables (Systat v.8, SPSS, Inc.). Correlations between PRI, pigment content and electron transport capacity were examined with the Pearson correlation analysis (Systat v.8 SPSS, Inc.). Percentage differences between spring and control sites were calculated as [(spring site - control site $) /$ control site $] * 100$. Other values are presented as mean \pm one standard error of the mean $(\mathrm{SEM})$.

\section{RESULTS}

Average daily atmospheric $\mathrm{CO}_{2}$ concentrations during our sampling period were $368 \mu \mathrm{mol} \mathrm{mol}{ }^{-1}( \pm 3, \mathrm{n}=5$ days $)$ and $664 \mu \mathrm{mol} \mathrm{mol}^{-1}( \pm 70, \mathrm{n}=6$ days $)$ at the Bossoleto control and spring sites, respectively, and $353 \mu \mathrm{mol} \mathrm{mol}^{-1}$ (n=1 day) and $830 \mu \mathrm{mol} \mathrm{mol}{ }^{-1}$ 
$( \pm 21, n=2$ days $)$ at the Laiatico control and spring sites, respectively. These values agree with other estimates of $\left[\mathrm{CO}_{2}\right]$ at the Bossoleto and Laiatico sites (Körner \& Miglietta 1994; Hättenschwiler et al. 1997a; Schulte et al. 1998). In our study, IRGA measurements at the Laiatico spring likely overestimated $\left[\mathrm{CO}_{2}\right]$ available to the study trees because the IRGA was several meters closer to the vents than were the study trees. Minute-to-minute $\left[\mathrm{CO}_{2}\right]$ fluctuations were large (up to $10,000 \mu \mathrm{mol} \mathrm{mol}{ }^{-1}$ ) at both $\mathrm{CO}_{2}$ springs but did not appear to affect physiological measurements (data not shown). For example, the standard deviation values for $\Delta \mathrm{F} / \mathrm{Fm}$ ' for each tree (typically measured every few minutes for 30 to 90 minutes) were relatively small and similar in magnitude at the spring and control sites $(\leq 0.07)$.

Net carbon assimilation at growth $\left[\mathrm{CO}_{2}\right]$ was $77 \%$ higher at the Bossoleto spring $(P=0.008)$ and $36 \%$ higher at the Laiatico spring $(P=0.096)$ than at their respective control sites (Table 1). Stomatal conductance was not significantly different at these sites. At both the Bossoleto and Laiatico study sites, no photosynthetic downregulation was evident from modeled biochemical parameters and gas exchange measurements. Specifically, Rubisco carboxylation capacity $\left(V_{\mathrm{cmax}}\right)$, electron transport capacity $\left(J_{\max }\right)$, and maximum carbon assimilation $\left(A_{\max }\right)$ were not significantly different for the two springs and their respective control sites (Fig. 1). Similarly, photosynthetic rates measured at a common $\mathrm{CO}_{2}$ concentration ( 350 or $600 \mu \mathrm{mol} \mathrm{mol}{ }^{-1}$ ) were not significantly different between trees at the Bossoleto control and spring sites $\left(350 \mu \mathrm{mol} \mathrm{mol}^{-1}, P=0.78\right.$ and $600 \mu \mathrm{mol} \mathrm{mol}{ }^{-1}, P=0.19$; not shown).

Variations in leaf chemistry at the Bossoleto study site were consistent with photosynthetic trends (Table 2). Total nitrogen content and Rubisco content, activity, and 
activation state were not significantly different between the Bossoleto spring and control sites. Although Rubisco was not measured at the Laiatico study site, $V_{\text {cmax }}$ correlates with Rubisco content and activity (Sage 1994; $\mathrm{r}^{2}=0.91$ and 0.87 in this study). The lack of an elevated- $\left[\mathrm{CO}_{2}\right]$ effect on $V_{\text {cmax }}$ suggests there was no difference between Rubisco pools of leaves at the Laiatico spring and control sites. Content of chlorophyll, carotenoids, and xanthophyll cycle pigments (expressed per leaf area or per chlorophyll content) and deepoxidization state of xanthophyll cycle pigments also did not differ between the Bossoleto spring and control sites. Sugar and TNC content and carbon-to-nitrogen ratios were similar for plants growing at the Bossoleto spring and control sites. Only starch content differed notably between these sites, measuring higher at the $\mathrm{CO}_{2}$ spring $(42 \%, P=0.10)$.

The degree of multiple scattering of light through the mesophyll layer of a leaf determines reflectance in the near-infrared wavebands (700-1000 nm) (Gausman 1985). By this measure there was no apparent effect of $\left[\mathrm{CO}_{2}\right]$ enrichment on leaf spectra of $\underline{Q}$. pubescens (data not shown), suggesting that leaf thickness was not altered by growth at high $\left[\mathrm{CO}_{2}\right]$. Additionally and in agreement with the HPLC analysis, leaf NDVI for Q. pubescens trees was not significantly different at the Bossoleto and Laiatico study sites, indicating no difference in chlorophyll content (Fig. 2; also see Table 2). Despite enhanced carbon assimilation at growth $\left[\mathrm{CO}_{2}\right]$, PRI also did not differ significantly between spring and control trees at these sites, indicating no difference in xanthophyll cycle pigment levels. Likewise, $\Delta \mathrm{F} / \mathrm{Fm}^{\prime}$ was not significantly different at the Laiatico spring and control sites and was only $15 \%$ higher at the Bossoleto spring site compared to the control site $(P=0.09)$.

When data from the Bossoleto spring and control sites were combined, total content of xanthophyll cycle pigments was well correlated with PRI $\left(r^{2}=0.75\right.$, Fig. 3), suggesting 
that this in situ optical measurement (normalized for incident light) is a valid surrogate for these pigments. A strong relationship between PRI and xanthophyll cycle pigments has also been observed for several other species (Peñuelas et al. 1994; Gamon et al. 1997; Gamon \&

Surfus 1999; Stylinski 2000). Total content of xanthophyll cycle pigments was also well correlated with $J_{\max }\left(\mathrm{r}^{2}=0.92\right)$. When Laiatico and Bossoleto data were combined, PRI also correlated with $J_{\max }$ (overall $\mathrm{r}^{2}=0.79, P<0.001$ ). A single modeled value (unfilled symbol, Fig. 3) was treated as an outlier and excluded from the correlation analyses. Note that we were not able to measure $A / C_{\mathrm{i}}$ curves and leaf reflectance on the same leaves or the same dates, which may have led to this discrepancy.

\section{DISCUSSION}

In early summer, net carbon assimilation was stimulated $36 \%$ and $77 \%$ for mature Quercus pubescens trees growing in native soils and with lifelong $\left[\mathrm{CO}_{2}\right]$ enrichment at two $\mathrm{CO}_{2}$ springs compared to nearby control sites. By contrast, stomatal conductance did not differ between the spring and control sites. These findings agree with many other tree studies investigating exposure to $\left[\mathrm{CO}_{2}\right]$ enrichment (see reviews by Curtis \& Wang 1998, Saxe et al. 1998, Norby et al. 1999 and Medlyn et al. 1999). If maintained, enhanced leaf photosynthetic rates at the $\mathrm{CO}_{2}$ springs could increase carbon sequestering and productivity of whole tree canopies. Furthermore, because trees contribute significantly to terrestrial carbon fixation (Meyer \& Turner 1992; Melilo et al. 1993), higher carbon acquisition by Q. pubescens and other species could slow the rise in atmospheric $\left[\mathrm{CO}_{2}\right]$. However, elevated$\left[\mathrm{CO}_{2}\right]$ effects on respiratory loss of carbon and on higher-level plant attributes (e.g., canopy leaf area) must also be examined to predict the response of whole trees and stands to $\left[\mathrm{CO}_{2}\right]$ enrichment (Saxe et al. 1998; Norby et al. 1999). 
Photosynthetic downregulation was not observed for $\mathrm{Q}$. pubescens trees growing at the $\mathrm{CO}_{2}$ springs early in the growing season, when sink demand likely was greatest. When downregulation occurs, maximum carbon assimilation $\left(A_{\max }\right)$, electron transport capacity $\left(J_{\text {max }}\right)$, and Rubisco content, activity, and carboxylation capacity $\left(V_{\text {cmax }}\right)$ are typically lower in plants growing under elevated $\left[\mathrm{CO}_{2}\right]$ than in those growing under ambient $\left[\mathrm{CO}_{2}\right]($ Sage, Sharkey \& Seemann 1989; Stitt 1991; Sage 1994). In our study, these variables were not significantly different between trees growing at the two $\mathrm{CO}_{2}$ springs and their respective control sites. The absence of photosynthetic downregulation in current-year leaves has been observed in other studies of trees with unlimited rooting volume that were exposed to elevated $\left[\mathrm{CO}_{2}\right]$ (e.g., Idso et al. 1991, 1995; Gunderson et al. 1993; Teskey 1995; ScarasciaMugnozza et al. 1996; Hogan et al. 1997; Turnbull et al. 1998). These studies include initial investigations at the Bossoleto spring and control sites, which found no difference in photosynthetic capacity in early summer for Q. pubescens (van Gardingen et al. 1997; Tognetti et al. 1998). At another Italian $\mathrm{CO}_{2}$ spring, Jones et al. (1995) also reported no photosynthetic downregulation of $\underline{A}$. unedo trees in early summer.

These findings on current-year foliage (typically measured at the beginning of the growing season) contrast with well-documented diminished photosynthetic capacity under high $\left[\mathrm{CO}_{2}\right]$ of older leaves and of leaves under less than optimal environmental conditions (e.g., Mousseau 1993; Tissue et al. 1993, 1997, 1999; Lewis et al. 1996; Rey \& Jarvis 1998; Spunda et al. 1998; Turnbull et al. 1998; also see review by Medlyn et al. 1999). For example, $A_{\max }$ did not differ for new $Q$. ilex leaves but was downregulated for one-year-old leaves at the Laiatico $\mathrm{CO}_{2}$ spring compared to a control site (C. Cario et al. unpublished 
data). Similarly, photosynthetic capacity of $\underline{Q}$. pubescens at the $\mathrm{CO}_{2}$ springs may be lower in the summer and autumn months, when sink demand is reduced.

Q. pubescens at the Bossoleto $\mathrm{CO}_{2}$ spring had no foliar sugar accumulation and only moderate starch accumulation, indicating that these trees have an active carbon sink within or near the leaves and that the leaves can effectively translocate surplus assimilates (Saxe et al. 1998). Higher rates of leaf isoprene emission by $\underline{Q}$. pubescens at the Bossoleto spring may also limit carbohydrate accumulation in the leaves (Tognetti et al. 1998). Trees growing at the $\mathrm{CO}_{2}$ springs also did not have lower foliar nitrogen and/or Rubisco (estimated by wet chemistry or $V_{\text {cmax }}$ ), possibly due to larger soil total nitrogen pools and higher nitrogen mineralization rates at the $\mathrm{CO}_{2}$ springs (Raiesi 1998a, b). In general, these biochemical results agree with other studies of perennial species growing at Italian $\mathrm{CO}_{2}$ springs (Körner \& Miglietta 1994; Bettarini et al. 1995; Jones et al. 1995; Miglietta et al. 1995).

Increased biomass may provide a sink for the surplus carbon fixed by trees at Italian $\mathrm{CO}_{2}$ springs. Raiesi (1998a, b) attributed higher carbon and nitrogen pools $\left(\mathrm{g} \mathrm{m}^{-2}\right)$ in the soil at the Laiatico spring to enhanced net primary productivity of the surrounding vegetation. Additionally, Hättenschwiler et al. (1997a) noted higher radial stem width in young $\mathrm{Q}$. ilex trees at the Bossoleto and Laiatico $\mathrm{CO}_{2}$ springs compared to control trees. By contrast, Hättenschwiler et al. (1997b) found lower leaf area per unit branch biomass for Q. $\underline{\mathrm{ilex}}$ at the Bossoleto spring. However, these branch data do not necessarily apply to $\underline{Q}$. pubescens or scale up to the whole tree. Indeed, many other studies have reported no change or an increase in leaf area index with elevated $\left[\mathrm{CO}_{2}\right]$ (e.g., Tissue et al. 1997; also see reviews by Saxe et al. 1998 and Norby et al. 1999). 
Given similar irradiance and absorptance, we hypothesized that enhanced carbon assimilation rates with elevated $\left[\mathrm{CO}_{2}\right]$ would reduce content and activity of xanthophyll cycle pigments (as measured optically in situ or by wet chemistry) and improve PSII photochemical efficiency $(\Delta \mathrm{F} / \mathrm{Fm}$ '). However, with the exception of a small increase in $\Delta \mathrm{F} / \mathrm{Fm}$ ' at the Bossoleto spring site, these variables did not differ between the spring and control sites, despite the significant stimulation of net photosynthesis at growth $\left[\mathrm{CO}_{2}\right]$. This pattern was also observed in June 1997 for mature Q. ilex trees exposed to $\left[\mathrm{CO}_{2}\right]$ two times greater than ambient levels for more than seven years in open-top chambers in a central Italy forest (C. Stylinski, G. Matteucci \& P. De Angelis, unpublished data; also see Scarascia-Mugnozza et al. 1996). Furthermore, Hogan et al. (1997) reported higher photosynthetic rates at growth $\left[\mathrm{CO}_{2}\right]$ and no change in total and de-epoxidized pools of xanthophyll cycle pigments and $\Delta \mathrm{F} / \mathrm{Fm}$ ' (normalized for incident light) of Nothofagus fusca (Hook F.) Oersted and Pinus radiata D. Don seedlings grown with elevated $\left[\mathrm{CO}_{2}\right]$ compared to those grown at ambient $\left[\mathrm{CO}_{2}\right]$. However, studies of other woody species have recorded higher and lower $\Delta \mathrm{F} / \mathrm{Fm}$ ' with long-term $\left[\mathrm{CO}_{2}\right]$ enrichment (see review by Saxe $e t$ al. 1998). Inconsistent trends are also reported for maximum PSII photochemical efficiency for woody species under high $\left[\mathrm{CO}_{2}\right]$ (e.g., Jones et al. 1995; Faria et al. 1996; ScarasciaMugnozza et al. 1996; Hogan et al. 1997; Spunda et al. 1998). Additionally, antioxidants another photoprotective mechanism - are reportedly both higher and lower with $\left[\mathrm{CO}_{2}\right]$ enrichment (Badiani et al. 1993; Schwanz et al. 1996; Polle et al. 1997; Schwanz \& Polle 1998). Overall, these contradictory effects of elevated $\left[\mathrm{CO}_{2}\right]$ on xanthophyll cycle pigments, antioxidants and PSII photochemical efficiency suggest that we do not have a clear understanding of the response of photoprotective mechanisms to $\left[\mathrm{CO}_{2}\right]$ enrichment. 
Leaf age and developmental history and resource availability certainly influence these responses (Saxe et al. 1998), particularly of xanthophyll cycle pigments (Demmig-Adams \& Adams 1996; Gamon et al. 1997; Gamon \& Surfus 1999), and some of these could have been complicating factors in our study.

While others have reported a link between xanthophyll cycle pigments and photosynthesis (both measured under full midday sunlight; Thayer \& Björkman 1990; Gamon et al. 1997), our results demonstrate that xanthophyll cycle pigments and thus PRI are poor indicators of carbon assimilation at growth $\left[\mathrm{CO}_{2}\right]$ for plants growing under longterm $\left[\mathrm{CO}_{2}\right]$ enrichment. However, these pigments and PRI were well correlated with $J_{\max }$ of Q. pubescens. This relationship with $J_{\max }$ occurs because downregulation of electron transport capacity is associated with a rise in non-photochemical quenching of chlorophyll fluorescence (Weis \& Berry 1987); xanthophyll cycle pigments provide a form of nonphotochemical quenching (Demmig-Adams \& Adams 1992; Chaumont, Morot-Gaudry \& Foyer 1995). This relationship may be useful for other investigations and deserves further exploration.

In conclusion, photosynthesis of mature $\underline{Q}$. pubescens trees with unlimited rooting volume was not downregulated with lifetime exposure to elevated $\left[\mathrm{CO}_{2}\right]$, at least early in the growing season when resources were readily available. Despite enhanced carbon assimilation rates at the $\mathrm{CO}_{2}$ springs, investments in photoprotective xanthophyll cycle pigment were not reduced. Although PSII photochemical efficiency of light-adapted leaves was slightly higher at one $\mathrm{CO}_{2}$ spring, the capacity of electron transport was not affected by $\left[\mathrm{CO}_{2}\right]$ enrichment at either study site. Both PRI and the total pool of xanthophyll cycle pigments were well correlated with electron transport capacity of $\mathbf{Q}$. pubescens. However, 
neither variable was a useful indicator of carbon assimilation at growth $\left[\mathrm{CO}_{2}\right]$ for plants under long-term $\left[\mathrm{CO}_{2}\right]$ enrichment.

\section{ACKNOWLEDGEMENTS}

We gratefully acknowledge K. Pence for assistance in the field, and I. Bettarini, F. Vacarri, F. Sabbatini, and G. Tagliaferri of IATA for assistance with travel and supplies. PP Systems (Haverhill, MA) kindly provided the Unispec spectrometer. This research was supported by an NSF international dissertation enhancement grant (INT-9622561) and a NASA Graduate Fellowship (NGT-30311; NGT5-30118) to CDS and by a Department of Energy research grant (DE-FG03-93ER61715) to WCO. 


\section{REFERENCES}

Badiani M., D'Annibale A., Paolacci A.R., Miglietta F. \& Raschi A. (1993) The antioxidant status of soybean (Glycine max ) leaves grown under natural $\mathrm{CO}_{2}$ enrichment in the field. Australian Journal of Plant Physiology 20, 275-284.

Barták M., Nijs I. \& Impens I. (1996) The effects of long-term exposure of Lolium perenne L. plants to elevated $\mathrm{CO}_{2}$ and/or elevated air temperature on quantum yield of photosystem 2 and net photosynthesis. Photosynthetica 32, 549-562.

Bettarini I., Calderoni G., Miglietta F., Raschi A. \& Ehleringer J. (1995) Isotopic carbon discrimination and leaf nitrogen content of Erica arborea L. along a $\mathrm{CO}_{2}$ concentration gradient in a $\mathrm{CO}_{2}$ spring in Italy. Tree Physiology 15, 327-332.

Chaumont M., Morot-Gaudry J.-F. \& Foyer C.H. (1995) Effects of photoinhibitory treatment on $\mathrm{CO}_{2}$ assimilation, the quantum yield of $\mathrm{CO}_{2}$ assimilation, $\mathrm{D}_{1}$ protein, ascorbate, glutathione and xanthophyll contents and the electron transport rate in vine leaves. Plant, Cell \& Environment 18, 1358-1366.

Cook A.C., Tissue D.T., Roberts S.W. \& Oechel W.C. (1998) Effects of long-term elevated $\left[\mathrm{CO}_{2}\right]$ from natural $\mathrm{CO}_{2}$ springs on Nardis stricta: photosynthesis, biochemistry, growth and phenology. Plant, Cell \& Environment 21, 417-425.

Curtis P.S. \& Wang X. (1998) A meta-analysis of elevated $\mathrm{CO}_{2}$ effects on woody plant mass, form, and physiology. Oecologia 113, 299-313.

Demmig-Adams B. \& Adams III W.W. (1992) Carotenoid composition in sun and shade leaves of plants with different life forms. Plant, Cell \& Environment 15, 411-419.

Demmig-Adams B. \& Adams III W.W. (1996) The role of xanthophyll cycle carotenoids in the protection of photosynthesis. Trends in Plant Science 1, 21-26.

Eamus D. \& Jarvis P.G. (1989) The direct effects of increase in the global atmospheric $\mathrm{CO}_{2}$ concentration on natural and commercial temperate trees and forests. In: Advances in Ecological Research (eds M. Begon, A.H. Fitter, E.D. Ford \& A. Macfadyen), pp. 2-57. Academic Press, London.

Faria T., Wilkins D., Besford R.T., Vaz M., Pereira J.S. \& Chaves M.M. (1996) Growth at elevated $\mathrm{CO}_{2}$ leads to down-regulation of photosynthesis and altered response to high temperature in Quercus suber L. seedlings. Journal of Experimental Botany 47, 1755-1761.

Frank H.A., Cua A., Chynwat V., Young A., Gosztola D. \& Wasielewski M.R. (1994) Photophysics of the carotenoids associated with the xanthophyll cycle in photosynthesis. Photosynthesis Research 41, 389-395.

Gaines T.P. (1973) Automated determination of reducing sugars, total sugars and starch in plant tissue. Journal of the Association of Analytical Chemistry 56, 1419-1424.

Gamon J.A. \& Qiu H.-L. (1999) Ecological applications of remote sensing at multiple scales. In: Handbook of Functional Plant Ecology (eds F. I. Pugnaire \& F. Valladares), pp.805-846. Marcel Dekker, Inc., New York, NY.

Gamon J.A., Serrano L. \& Surfus J.S. (1997) The photohemical reflectance index: an optical indicator of photosynthetic radiation use efficiency across species, functional types, and nutrient levels. Oecologia 112, 492-501.

Gamon J.A. \& Surfus J.S. (1999) Assessing leaf pigment content with a reflectometer. New Phytologist 143, 105-117. 
Gausman H.W. (1985) Plant Leaf Optical Properties in Visible and Near-Infrared Light. Texas Tech Press, Lubbock, TX.

Genty B., Briantais J.-M. \& Baker N.R. (1989) The relationship between the quantum yield of photosynthetic electron transport and quenching of chlorophyll fluorescence. Biochimica et Biophysica Acta 990, 87-92.

Gitelson A. \& Merzylak M.N. (1994) Spectral reflectance changes associated with autumn senescence of Aesculus hippocastanum L. and Acer platanoides L. leaves. Spectral features and relation to chlorophyll estimation. Journal of Plant Physiology 143, 286-292.

Griffin K.L. \& Seemann J.R. (1996) Plants, $\mathrm{CO}_{2}$ and photosynthesis in the $21^{\text {st }}$ century. Chemistry \& Biology 3, 245-254.

Gunderson C.A., Norby R.J. \& Wullschleger S.D. (1993) Foliar gas exchange responses of two deciduous hardwoods during 3 years of growth in elevated $\mathrm{CO}_{2}$ : no loss of photosynthetic enhancement. Plant, Cell \& Environment 16, 797-807.

Harley P.C. \& Sharkey T.D. (1991) An improved model of $\mathrm{C}_{3}$ photosynthesis at high $\mathrm{CO}_{2}$ : reversed $\mathrm{O}_{2}$ sensitivity explained by lack of glycerate re-entry into the chloroplast. Photosynthesis Research 27, 169-178.

Harley P.C., Thomas R.B., Reynolds J.F. \& Strain B.R. (1992) Modelling photosynthesis of cotton grown in elevated $\mathrm{CO}_{2}$. Plant, Cell \& Environment 15, 271-282.

Harmon M.E., Ferrell W.K. \& Franklin J.F. (1990) Effects of carbon storage on conversion of old-growth forests to young forests. Science 247, 699-702.

Hättenschwiler S., Miglietta F., Raschi A. \& Körner C. (1997a) Thirty years of in situ tree growth under elevated $\mathrm{CO}_{2}$ : a model for future forest responses? Global Change Biology 3, 463-471.

Hättenschwiler S., Miglietta F., Raschi A. \& Körner C. (1997b) Morphological adjustment of mature Quercus ilex trees to elevated $\mathrm{CO}_{2}$. Acta Ecologica 18, 361-365.

Hogan K.P., Fleck I., Bungard R., Cheeseman J. M. \& Whitehead D. (1997) Effect of elevated $\mathrm{CO}_{2}$ on the utilization of light energy in Nothofagus fusca and Pinus radiata. Journal of Experimental Botany 48, 1289-1297.

Idso S.B., Idso K.E., Garcia R. L., Kimball B.A. \& Hoober J.K. (1995) Effects of atmospheric $\mathrm{CO}_{2}$ enrichment and foliar methanol application on net photosynthesis of sour orange tree (Citrus aurantium; Rutaceace) leaves. American Journal of Botany 82, 26-30.

Idso S.B., Kimball B.A. \& Allen S.G. (1991) $\mathrm{CO}_{2}$ enrichment of sour orange trees: 2.5 years into a long-term experiment. Plant, Cell \& Environment 14, 351-353.

Jones M.B., Brown J.C., Raschi A. \& Miglietta F. (1995) The effects on Arbutus unedo L. of long-term exposure to elevated $\mathrm{CO}_{2}$. Global Change Biology 1, 295-302.

Körner C. \& Miglietta F. (1994) Long term effects of naturally elevated $\mathrm{CO}_{2}$ on mediterranean grassland and forest trees. Oecologia 99, 343-351.

Lee H.S.J. \& Jarvis P. G. (1995) Trees differ from crops and from each other in their responses to increases in $\mathrm{CO}_{2}$ concentration. Journal of Biogeography 22, 323-330.

Lewis J.D., Tissue D.T. \& Strain B.R. (1996) Seasonal response of photosynthesis to elevated $\mathrm{CO}_{2}$ in loblolly pine (Pinus taeda L.) over two growing seasons. Global Change Biology 2, 103-114. 
Long S.P. \& Drake B.G. (1991) Effect of long-term elevation of $\mathrm{CO}_{2}$ concentration in the field on quantum yield of photosynthesis of the $\mathrm{C}_{3}$ sedge Scirpus olneyi. Plant Physiology 96, 221-226.

Medlyn B.E., Badeck F.-W., De Pury D.G.G., Barton C.V.M., Broadmeadow M., Ceulemans R., De Angelis P., Forstreuter M., Jach M.E., Kellomäki S., Laitat E., Marek M., Philippot S., Rey A., Strassemeyer J., Laitinen K., Liozon R., Portier B., Roberntz P., Wang K. \& Jarvis P.G. (1999) Effects of elevated $\left[\mathrm{CO}_{2}\right]$ on photosynthesis in European forest species: a meta-analysis of model parameters. Plant, Cell \& Environment 22, 1475-1495.

Melilo J.M., McGuire A.D., Kicklighter D.W., Moore III B., Corosmarty C.J. \& Scholoss A.L. (1993) Global climate change and terrestrial net primary production. Nature 363, 234-240.

Meyer W.B. \& Turner B.L. (1992) Human population growth and global land-use/cover change. Annual Review of Ecology and Systematics 23, 39-61.

Miglietta F., Badiani M., Bettarini I., van Gardingen P., Selvi F. \& Raschi A. (1995) Preliminary studies of the long-term $\mathrm{CO}_{2}$ response of Mediterranean vegetation around natural $\mathrm{CO}_{2}$ vents. In: Global Change and Mediterranean-type Ecosystem (eds J.M. Moren \& W.C. Oechel), pp. 102-120. Springer, New York, NY.

Miglietta F., Raschi A., Bettarini I., Resti R. \& Selvi F. (1993a) Natural $\mathrm{CO}_{2}$ springs in Italy: a resource for examining long-term response of vegetation to rising atmospheric $\mathrm{CO}_{2}$ concentration. Plant, Cell \& Environment 16, 873-878.

Miglietta F., Raschi A., Resti R. \& Badiani M. (1993b) Growth and onto-morphogenesis of soybean (Glycine max Merril) in an open, naturally $\mathrm{CO}_{2}$ enriched environment. Plant, Cell \& Environment 16, 909-919.

Mousseau M. (1993) Effects of elevated $\mathrm{CO}_{2}$ on growth, photosynthesis and respiration of sweet chestnut (Castanea sativa Mill.). Vegetatio 104/105, 413-419.

Norby R.J., Wullscheger, S.D., Gunderson, C.A., Johnson, D.W. \& Ceulemans, R. (1999) Tree responses to rising $\mathrm{CO}_{2}$ in field experiments: implications for the future forest. Plant, Cell and Environment 22, 683-714.

Peñuelas J., Filella I. \& Gamon J.A. (1995) Assessment of photosynthetic radiation-use efficiency with spectral reflectance. New Phytologist 131, 291-296.

Peñuelas J., Gamon J.A., Fredeen A.L., Merino J. \& Field C.B. (1994) Reflectance indices associated with physiological changes in ntirogren- and water-limited sunflower leaves. Remote Sensing of Environment 48, 135-146.

Peñuelas J., Llusia J., Piñol J. \& Filella I. (1997) Photochemical reflectance index and leaf photosynthetic radiation-use efficiency assessment in Mediterranean trees. International Journal of Remote Sensing 18, 2863-2868.

Polle A., Eiblmeir M., Sheppard L. \& Murray M. (1997) Responses of antioxidant enzymes to elevated $\mathrm{CO}_{2}$ in leaves of beech (Fagus sylvatica L.) seedlings grown under a range of nutrient regimes. Plant, Cell \& Environment 20, 1317-1321.

Raiesi F.G. (1998a) Effects of elevated atmospheric $\mathrm{CO}_{2}$ on soil organic carbon dynamics in a Mediterranean forest ecosystem. Ph.D. dissertation, Wageningen Agricultural University, The Netherlands.

Raiesi F.G. (1998b) Impacts of elevated atmospheric $\mathrm{CO}_{2}$ on litter quality, litter decomposability and nitrogen turnover rate of two oak species in a Mediterranean forest ecosystem. Global Change Biology 4, 667-677. 
Rey A. \& Jarvis P.G. (1998) Long-term photosynthetic acclimation to increased atmospheric $\mathrm{CO}_{2}$ concentration in young birch (Betula pendula) trees. Tree Physiology 18, 441-450.

Sage R.F. (1994) Acclimation of photosynthesis to increasing atmospheric $\mathrm{CO}_{2}$ : the gas exchange perspective. Photosynthesis Research 39, 351-368.

Sage R.F., Sharkey T.D. \& Seemann J.F. (1989) Acclimation of photosynthesis to elevated $\mathrm{CO}_{2}$ in five $\mathrm{C}_{3}$ species. Plant Physiology 89, 590-596.

Saxe H., Ellsworth D.S. \& Heath J. (1998) Tansley Review No. 98, Tree and forest functioning in an enriched $\mathrm{CO}_{2}$ atmosphere. New Phytologist 139, 395-436.

Scarascia-Mugnozza G., De Angelis P., Matteucci G. \& Valentini R. (1996) Long-term exposure to elevated $\left[\mathrm{CO}_{2}\right]$ a natural Quercus ilex L. community: net photosynthesis and photochemical efficiency of PSII at different levels of water stress. Plant, Cell \& Environment 19, 643-654.

Schulte M., Raiesi F.G., Papke H., Buterback-Bahl K., van Breemen N. \& Renneberg H. (1998) $\mathrm{CO}_{2}$ concentration and atmospheric trace gas mixing ratio around natural $\mathrm{CO}_{2}$ vents in different Mediterranean forests in Central Italy. In: Effects of Elevated Atmospheric $\mathrm{CO}_{2}$ on Soil Organic Carbon Dynamics in a Mediterranean Forest Ecosystem. (F.G. Raiesi), pp. 17-40. Wageningen Agricultural University, The Netherlands.

Schwanz P., Kimball B.A., Idso S.B., Hendrix D.L. \& Polle A. (1996) Antioxidants in sun and shade leaves of sour orange trees (Citrus aurantium) after long-term acclimation to elevated $\mathrm{CO}_{2}$. Journal of Experimental Botany 47, 1941-1950.

Schwanz P. \& Polle A. (1998) Antioxidative systems, pigment and protein contents in leaves of adult mediterranean oak species (Quercus pubescens and Q. $\underline{\text { ilex) with }}$ lifetime exposure to elevated $\mathrm{CO}_{2}$. New Phytologist 140, 411-423.

Sharkey T.D. (1985) Photosynthesis of intact leaves of $C_{3}$ plants: physics, physiology and rate limitations. Botanical Review 51, 53-105.

Spunda V., Kalina J., Cajánek M., Pavlícková H. \& Marek V. (1998) Long-term exposure of Norway spruce to elevated $\mathrm{CO}_{2}$ concentration induces changes in photosystem II mimicking an adaptation to increased irradiance. Journal of Plant Physiology 152, 413-419.

Stitt M. (1991) Rising $\mathrm{CO}_{2}$ levels and their potential significance for carbon flow in photosynthetic cell. Plant, Cell \& Environment 14, 741-762.

Stylinski C.D. (2000) Effects of Resource Availability on Plant Reflectance and Physiology. Ph.D. dissertation. University of California, Davis \& San Diego State University, California.

Teskey R.O. (1995) A field study of the effects of elevated $\mathrm{CO}_{2}$ on carbon assimilation, stomatal conductance and leaf and branch growth of Pinus taeda trees. Plant, Cell \& Environment 18, 565-573.

Thayer S.S. \& Björkman O. (1990) Leaf xanthophyll content and composition in sun and shade determined by HPLC. Photosynthesis Research 23, 331-343.

Tissue D.T., Griffin K.L. \& Ball T. (1999) Photosynthetic adjustment in field-grown ponderosa pine trees after six years of exposure to elevated $\mathrm{CO}_{2}$. Tree Physiology 16, 49-59. 
Tissue D.T., Thomas R.B. \& Strain B.R. (1993) Long-term effects of elevated $\mathrm{CO}_{2}$ and nutrients on photosynthesis and Rubisco in loblolly pine seedlings. Plant, Cell \& Environment 16, 859-865.

Tissue D.T., Thomas R.B. \& Strain B.R. (1997) Atmospheric $\mathrm{CO}_{2}$ enrichment increases growth and photosynthesis of Pinus taeda: a 4 year experiment in the field. Plant, Cell \& Environment 20, 1123-1234.

Tognetti R., Johnson J.D., Michelozzi M. \& Raschi A. (1998) Response of foliar metabolism in mature trees of Quercus pubescens and Quercus ilex to long-term elevated $\mathrm{CO}_{2}$. Environmental \& Experimental Botany 39, 233-245.

Turnbull M.H., Tissue D.T., Griffin K.L., Rogers G.N.D. \& Whitehead D. (1998) Photosynthetic acclimation to long-term exposure to elevated $\mathrm{CO}_{2}$ concentration in

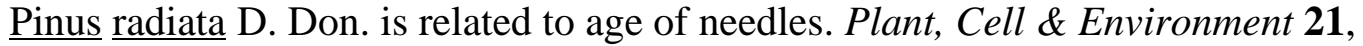
1019-1028.

van Gardingen P.R., Grace J., Harkness D.D., Miglietta F. \& Raschi A. (1995) Carbon dioxide emissions at an Italian mineral spring: measurements of average $\mathrm{CO}_{2}$ concentration and air temperature. Agricultural \& Forest Meteorology 73, 17-27.

van Gardingen P.R., Grace J., Jeffree C.E., Byari S.H., Miglietta F., Raschi A. \& Bettarini I. (1997) Long-term effects of enhanced $\mathrm{CO}_{2}$ concentrations on leaf gas exchange: research opportunities using $\mathrm{CO}_{2}$ springs. In: Plant Responses in Elevated Carbon Dioxide: Evidence from Natural Springs. (eds A. Raschi, F. Miglietta, R. Tognetti \& P.R. van Gardingen), pp. 69-86. Cambridge University Press, Cambridge.

von Caemmerer S. \& Farquhar G.D. (1981) Some relationships between the biochemistry of photosynthesis and the gas exchange rates of leaves. Planta 153, 376-387.

Walker J.C.G. \& Kasting J.F. (1992) Effects of fuel and forest conservation on future levels of atmospheric carbon dioxide. Palaeogeography Palaeoclimatology Palaeoecology 97, 151-189.

Weis E. \& Berry J.A. (1987) Quantum efficiency of photosystem II in relation to 'energy'dependent quenching of chlorophyll fluorescence. Biochimica et Biophysica Acta 894, 198-208.

Wullschleger S.D. (1993) Biochemical limitations to carbon assimilation in $\mathrm{C}_{3}$ plants - a retrospective analysis of the $A / C_{\mathrm{i}}$ curves from 109 species. Journal of Experimental Botany 44, 907-920. 
Table 1: Gas exchange rates of Quercus pubescens leaves measured at growth $\left[\mathrm{CO}_{2}\right]$ at the Laiatico and Bossoleto study sites. Growth $\left[\mathrm{CO}_{2}\right]$ was $350 \mu \mathrm{mol} \mathrm{mol}{ }^{-1}$ for control sites and $600 \mu \mathrm{mol} \mathrm{mol}^{-1}$ for spring sites. Values are means $\pm \mathrm{SEM}$ and were determined either from $A / C_{\mathrm{i}}$ curves (Laiatico; $\mathrm{n}=3$ ) or from gas exchange measurements made at 350 or $600 \mu \mathrm{mol}$ mol $^{-1}$ (Bossoleto; $\left.\mathrm{n}=4\right)$. $P$-values are from $t$-tests.

Gas exchange at growth $\left[\mathrm{CO}_{2}\right] \quad$ Control site $\quad$ Spring site $P$-value

Laiatico

\begin{tabular}{llll}
\hline Assimilation $\left(\mu \mathrm{mol} \mathrm{m} \mathrm{m}^{-2}\right)$ & $11.5 \pm 1.6$ & $15.6 \pm 0.6$ & 0.096 \\
Conductance $\left(\mathrm{mol} \mathrm{m}^{-2} \mathrm{~s}^{-1}\right)$ & $0.17 \pm 0.03$ & $0.15 \pm 0.03$ & 0.559
\end{tabular}

Bossoleto

\begin{tabular}{llll}
\hline Assimilation $\left(\mu \mathrm{mol} \mathrm{m} \mathrm{s}^{-1}\right)$ & $11.1 \pm 0.9$ & $19.7 \pm 1.7$ & 0.008 \\
Conductance $\left(\mathrm{mol} \mathrm{m}^{-2} \mathrm{~s}^{-1}\right)$ & $0.17 \pm 0.02$ & $0.16 \pm 0.02$ & 0.820
\end{tabular}


Table 2: Leaf chemistry of Quercus pubescens trees growing at the Bossoleto $\mathrm{CO}_{2}$ spring and control site. Values are means $\pm \mathrm{SEM}(\mathrm{n}=4) . P$-values are from $t$-tests. $[\mathrm{V}+\mathrm{A}+\mathrm{Z}]$ is total xanthophyll cycle pigments. De-epoxidization state is the proportion of pigments in the photoprotective state. TNC is total nonstructural carbohydrates.

Control site $\quad$ Spring site $\quad P$-value

Nitrogen

\begin{tabular}{lccc}
\hline Total nitrogen $(\%)$ & $2.0 \pm 0.1$ & $2.1 \pm 0.1$ & 0.64 \\
Rubisco content $\left(\mathrm{mg} \mathrm{m}^{-2}\right)$ & $1088 \pm 88$ & $1186 \pm 36$ & 0.36 \\
Rubisco activity & $45.3 \pm 3.9$ & $50.9 \pm 0.7$ & 0.25 \\
$\left(\mu \mathrm{mol} \mathrm{m} \mathrm{s}^{-1}\right)$ & & & \\
Rubisco activation state $(\%)$ & $69.2 \pm 0.6$ & $68.9 \pm 1.2$ & 0.84
\end{tabular}

Pigments

\begin{tabular}{lccc}
\hline Chlorophyll $\left(\mu \mathrm{mol} \mathrm{m}{ }^{-2}\right)$ & $432 \pm 60$ & $375 \pm 66$ & 0.55 \\
Carotenoid $\left(\mu \mathrm{mol} \mathrm{m}^{-2}\right)$ & $191 \pm 19$ & $157 \pm 19$ & 0.26 \\
Chlorophyll $/$ Carotenoid & $2.2 \pm 0.1$ & $2.3 \pm 0.1$ & 0.60 \\
{$[\mathrm{~V}+\mathrm{A}+\mathrm{Z}]\left(\mu \mathrm{mol} \mathrm{m}{ }^{-2}\right)$} & $38 \pm 3$ & $31 \pm 3$ & 0.22 \\
{$[\mathrm{~V}+\mathrm{A}+\mathrm{Z}] /$ Chlorophyll } & $0.1 \pm 0.0$ & $0.1 \pm 0.0$ & 0.85 \\
De-epoxidation state & $0.5 \pm 0.1$ & $0.5 \pm 0.1$ & 1.00
\end{tabular}

Carbon

\begin{tabular}{lccc}
\hline TNC (\%) & $21.4 \pm 1.9$ & $25.4 \pm 2.0$ & 0.20 \\
Total sugars (\%) & $18.1 \pm 1.7$ & $21.2 \pm 1.8$ & 0.25
\end{tabular}


Control site $\quad$ Spring site $P$-value

\begin{tabular}{lccc}
\hline \hline Starch (\%) & $3.6 \pm 0.2$ & $5.1 \pm 0.7$ & 0.10 \\
Carbon / Nitrogen & $26.4 \pm 1.6$ & $25.1 \pm 0.9$ & 0.52 \\
\hline
\end{tabular}




\section{FIGURE LEGENDS}

Figure 1: Modeled biochemical parameters based on analysis of $A / C_{\mathrm{i}}$ response curves for Quercus pubescens trees growing at two $\mathrm{CO}_{2}$ springs and control sites. Values are mean \pm $\operatorname{SEM}(\mathrm{n}=4$ at Bossoleto and $\mathrm{n}=3$ at Laiatico). $P$-values are from $t$-tests.

Figure 2: NDVI (a measure of chlorophyll content), PRI (a measure of xanthophyll cycle pigment activity) and PSII photochemical efficiency of light-adapted leaves ( $\Delta \mathrm{F} / \mathrm{Fm}$ ') measured at growth $\mathrm{CO}_{2}$ concentration for Quercus pubescens trees growing at the two $\mathrm{CO}_{2}$ springs and control sites. Values are mean $\pm \operatorname{SEM}(n=4$ at Bossoleto and $n=3$ at Laiatico). $P$-values are from $t$-tests.

Figure 3: Correlations between PRI, total pool of xanthophyll cycle pigments (normalized by chlorophyll) and $J_{\max }$ (modeled parameter of electron transport capacity) of Quercus pubescens trees. The top and left graphs are of $\underline{Q}$. pubescens at the Bossoleto site. The right graph includes both the Bossoleto (circles, solid line) and Laiatico (triangles, dashed line) sites. The unfilled symbol was treated as an outlier and not included in correlation analyses (see text for details). 

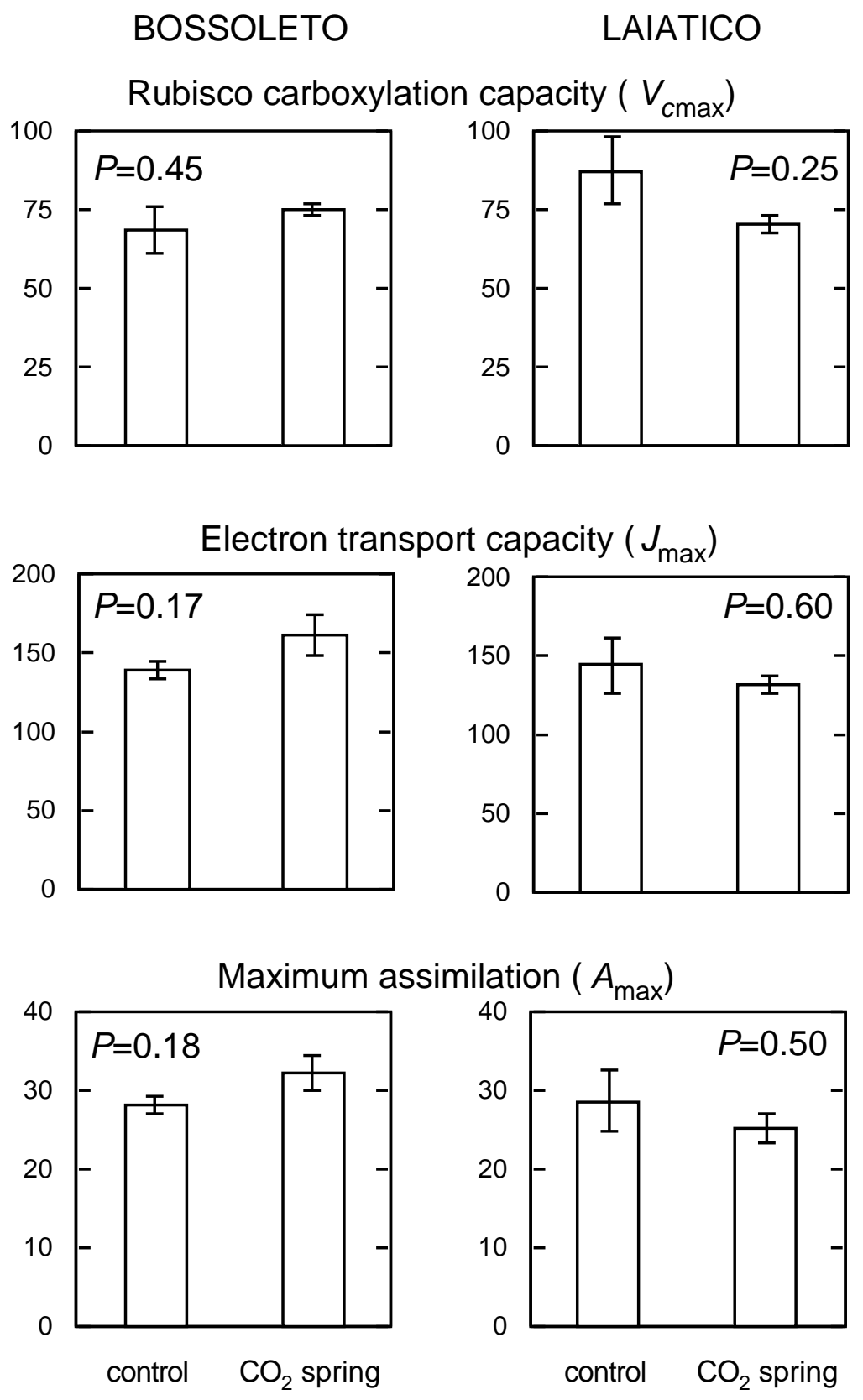

Figure 1 
BOSSOLETO

LAIATICO

Normalized Difference Vegetation Index (NDVI)
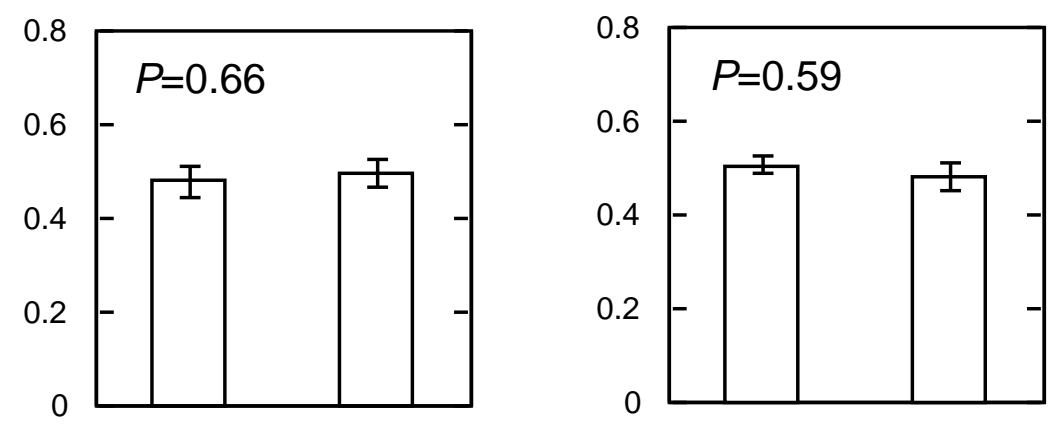

Photochemical Reflectance Index (PRI)
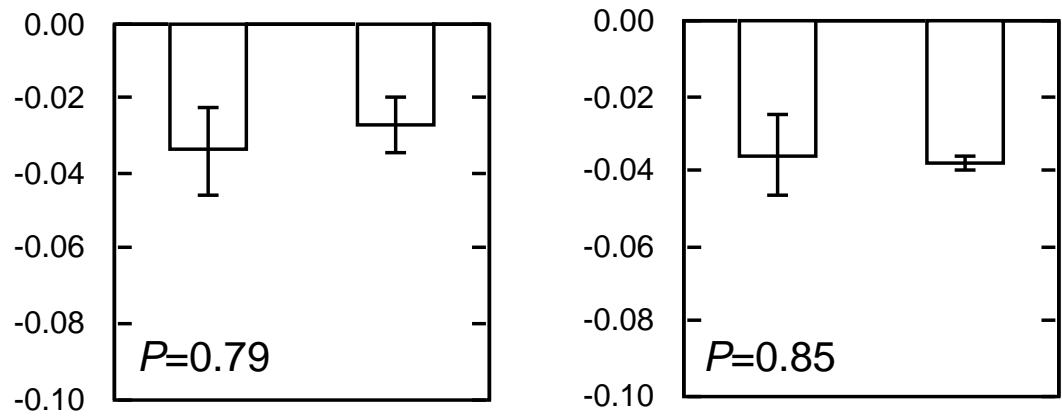

PSIl photochemical efficiency ( $\Delta \mathrm{F} / \mathrm{Fm}$ ')
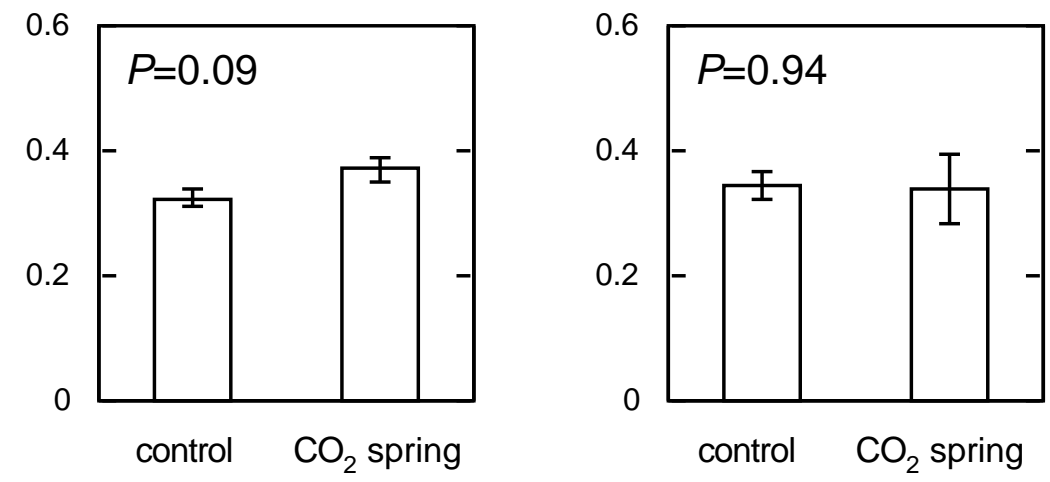

Figure 2 

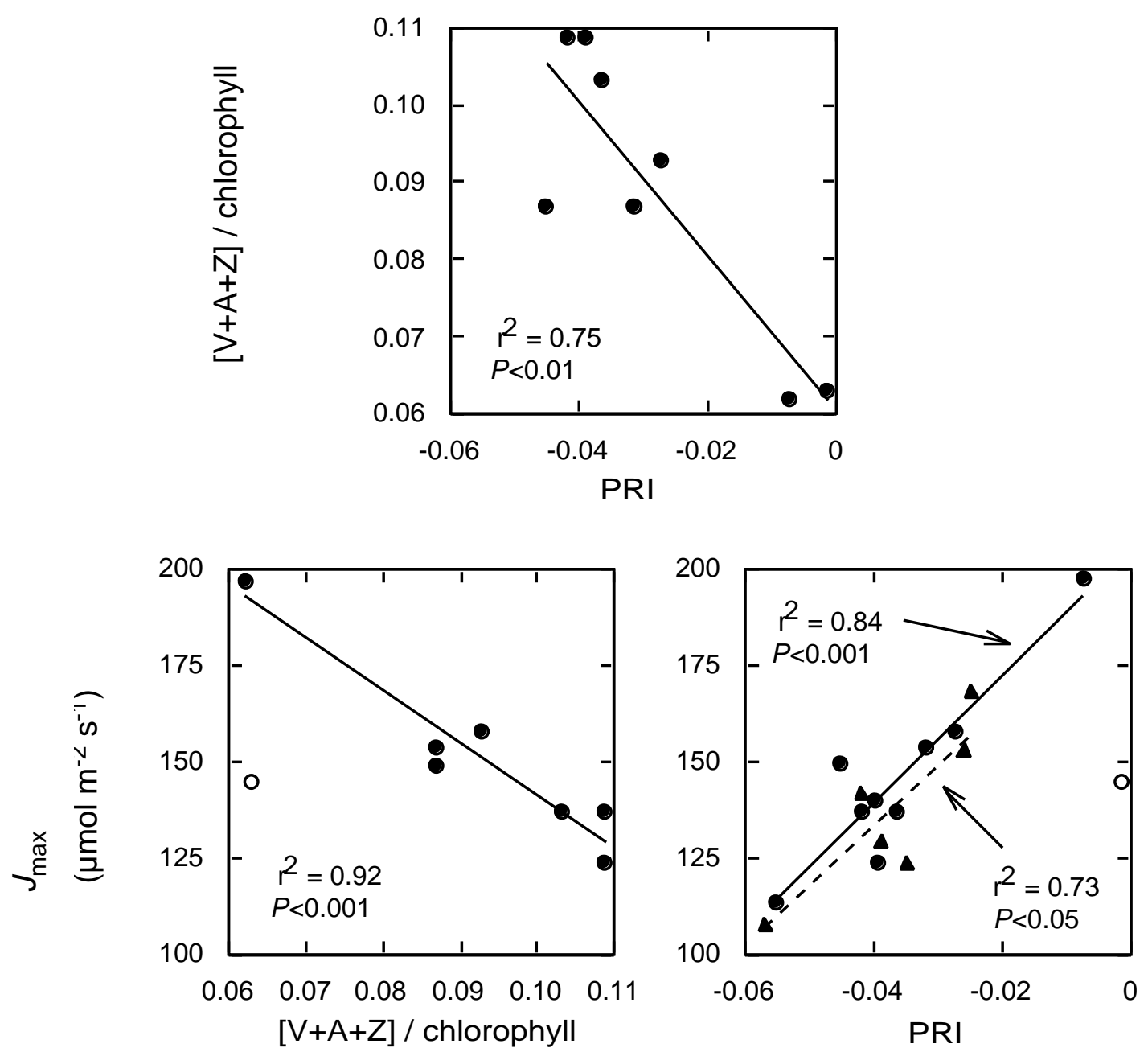

Figure 3 